\title{
Income, Poverty, and Health Insurance Coverage in the United States: 2005
}

\section{Current Population Reports} Consumer Income

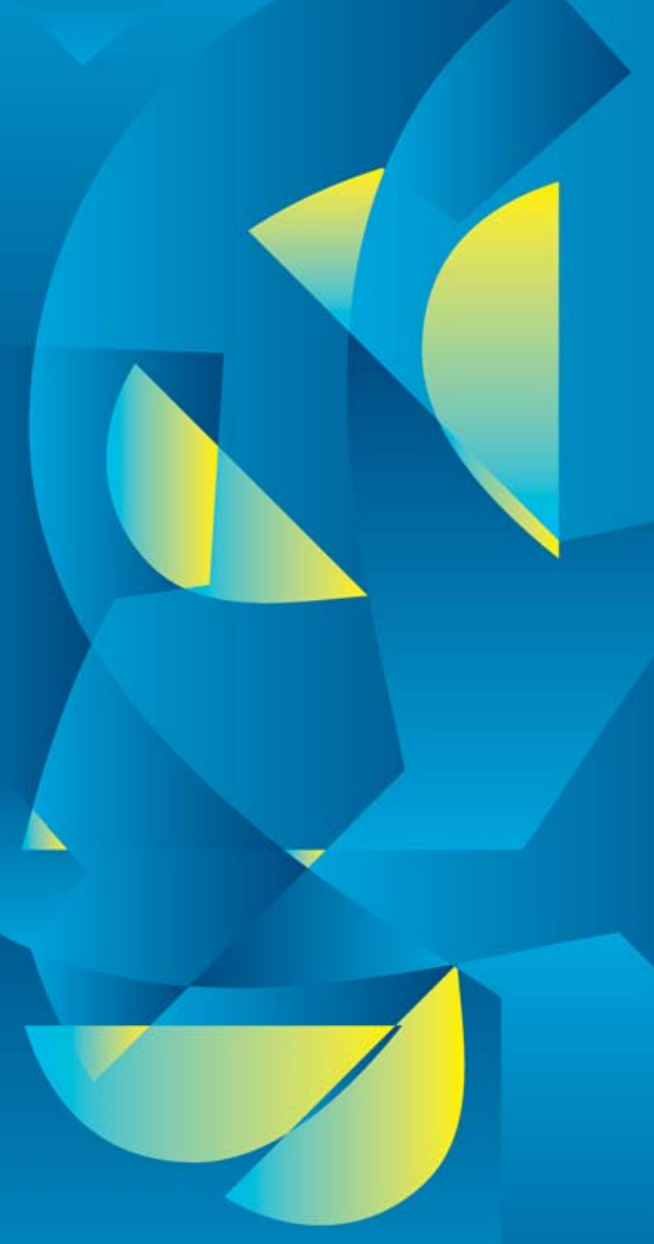


Carmen DeNavas-Walt prepared the income section of this report under the direction of Edward J. Welniak Jr., Chief of the Income Surveys Branch. Bernadette D. Proctor prepared the poverty section and Cheryl Hill Lee prepared the health insurance coverage section, both under the direction of Sharon Stern, Chief of the Poverty and Health Statistics Branch. Charles T. Nelson, Assistant Division Chief for Income, Poverty, and Health Statistics, Housing and Household Economic Statistics Division, provided overall direction.

Adelle D. Berlinger, George M. Mitcham, Tim J. Marshall, Robert E. Rothhaas, and Gregory D. Weyland, Demographic Surveys Division, processed the Current Population Survey 2006 Annual Social and Economic Supplement file. Caroline S.

Carbaugh, Chief of the Survey Processing Branch, Stacy J. Lyons, Mary Thrift Bush, Kirk E. Davis, Jaime L. Hasiuk, and Thy K. Le programmed and produced the detailed and publication tables.

Rebecca A. Olson, Jana Shepherd, and Michael White, under the supervision of David V. Hornick of the Demographic Statistical Methods Division, conducted sample review.

Bonnie S. Tarsia, Michelle L. Wiland, and Tim J. Marshall, Demographic Surveys Division, and Andrew M. Stevenson, Technologies Management Office, prepared and programmed the computer-assisted interviewing instrument used to conduct the Annual Social and Economic Supplement.

Additional people within the U.S. Census Bureau also made significant contributions to the preparation of this report. Joseph Dalaker, Marjorie Hanson, John Hisnanick, Len Norry, and Jessica L. Semega reviewed the contents. Jessica Smith, Ann Margaret Jensen, Kim Nguyen, and Miranda C. Hickman provided statistical assistance. Doris Sansbury provided clerical assistance.

Census Bureau field representatives and telephone interviewers collected the data. Without their dedication, the preparation of this report or any report from the Current Population Survey would be impossible.

Jan Sweeney, Jamie Peters, Theodora Forgione, and Don Meyd, of the Administrative and Customer Services Division, Walter C.

Odom, Chief, provided publications and printing management, graphics design and composition, and editorial review for print and electronic media. General direction and production management were provided by James R. Clark, Assistant Division Chief, and Wanda K. Cevis, Chief, Publications Services Branch. 


\section{Income, Poverty, and Health Insurance Coverage in the United States: 2005}

\section{U.S. Department of Commerce}

Carlos M. Gutierrez, Secretary

David A. Sampson, Deputy Secretary

Economics and Statistics Administration Vacant, Under Secretary for Economic Affairs

U.S. CENSUS BUREAU Charles Louis Kincannon, Director 


\section{Suggested Citation}

DeNavas-Walt, Carmen, Bernadette D.

Proctor, and Cheryl Hill Lee,

U.S. Census Bureau,

Current Population Reports, P60-231,

Income, Poverty, and Health Insurance Coverage in the United States: 2005,

U.S. Government Printing Office,

Washington, DC,

2006.

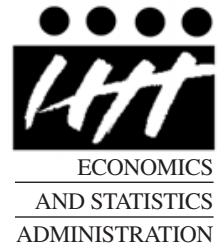

Economics and Statistics

Administration

Vacant,

Under Secretary for Economic Affairs

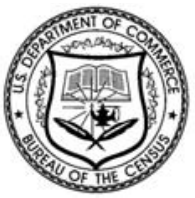

\section{U.S. CENSUS BUREAU}

\section{Charles Louis Kincannon,}

Director

Hermann Habermann,

Deputy Director and Chief Operating Officer

Howard Hogan,

Associate Director for Demographic Programs

David S. Johnson,

Chief, Housing and Household Economic Statistics Division

For sale by the Superintendent of Documents, U.S. Government Printing Office Internet: bookstore.gpo.gov Phone: toll-free 866-512-1800; DC area 202-512-1800 Fax: 202-512-2250 Mail: Stop SSOP, Washington, DC 20402-0001 
TEXT

Income, Poverty, and Health Insurance Coverage in

the United States: $2005 \ldots \ldots \ldots \ldots \ldots \ldots \ldots \ldots \ldots$

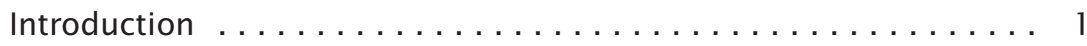

Source of Estimates and Statistical Accuracy ........... 1

State and Local Estimates of Income, Poverty,

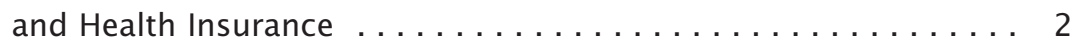

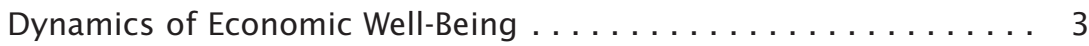

Income in the United States $\ldots \ldots \ldots \ldots \ldots \ldots \ldots \ldots$

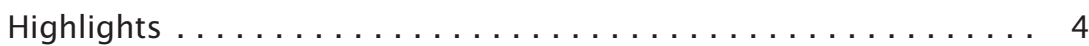

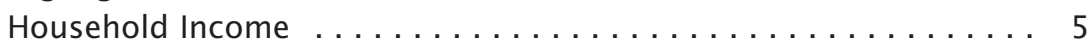

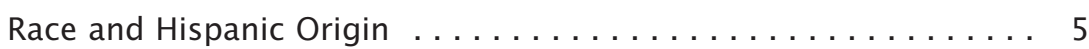

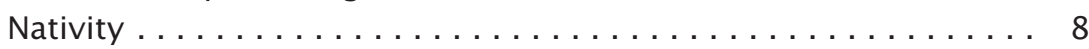

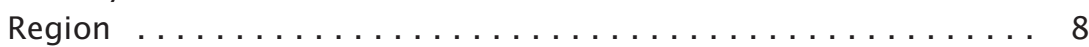

Income Inequality $\ldots \ldots \ldots \ldots \ldots \ldots \ldots \ldots \ldots \ldots \ldots$

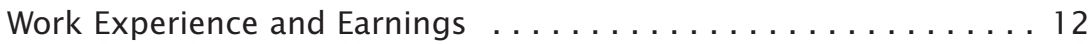

Per Capita Income . . . . . . . . . . . . . . . . 12

Poverty in the United States $\ldots \ldots \ldots \ldots \ldots \ldots \ldots \ldots \ldots \ldots$

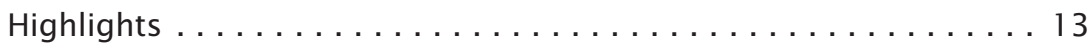

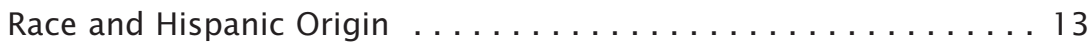

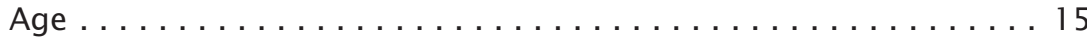

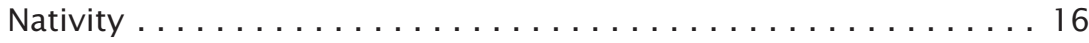

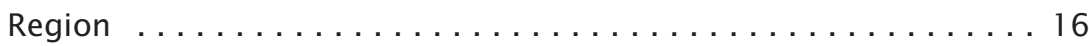

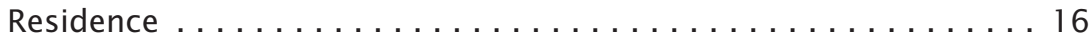

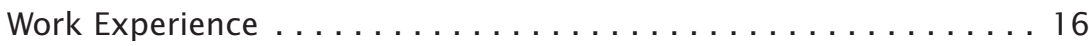

Families ........................ 16

Depth of Poverty Measures ................. 17

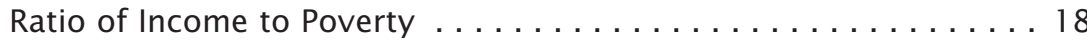

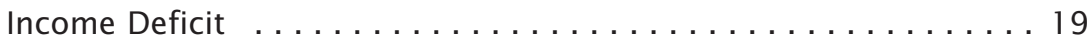

Health Insurance Coverage in the United States $\ldots \ldots \ldots \ldots 20$

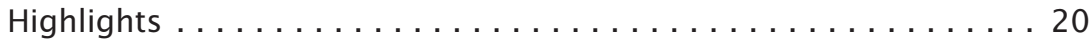

What Is Health Insurance Coverage? .............. 20

Type of Coverage ......................... 23

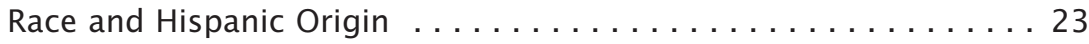

Nativity .............................. 24

Economic Status . . . . . . . . . . . . . . . . 24

Children's Health Insurance Coverage .............. 25

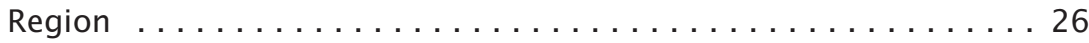

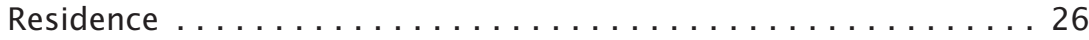

State Level Data ....................... 26

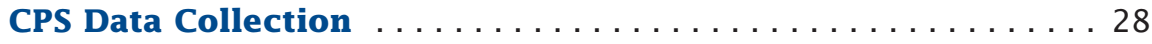

Additional Data and Contacts ................. 28

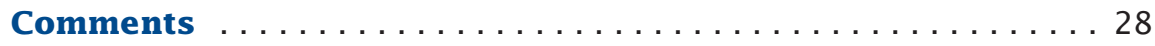




\section{TEXT TABLES}

1. Income and Earnings Summary Measures by Selected Characteristics: 2004 and $2005 \ldots \ldots \ldots \ldots$

2. Income of Households by Race and Hispanic Origin Using 3-Year-Average Medians: 2003 to $2005 \ldots$. 8

3. Distribution of Households by Selected Characteristics Within Income Quintiles: $2005 \ldots \ldots \ldots$. . . . 9

4. People and Families in Poverty by Selected Characteristics: 2004 and $2005 \ldots \ldots \ldots \ldots \ldots \ldots \ldots$

5. Number in Poverty and Poverty Rates by Race and Hispanic Origin Using

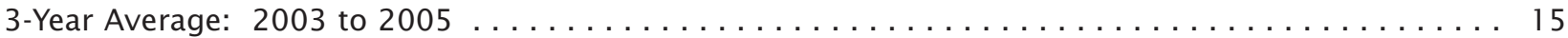

6. People With Income Below Specified Ratios of Their Poverty Thresholds by Selected Characteristics: $2005 \ldots \ldots \ldots \ldots \ldots \ldots \ldots \ldots \ldots \ldots \ldots \ldots \ldots \ldots \ldots \ldots$

7. Income Deficit or Surplus of Families and Unrelated Individuals by Poverty Status: $2005 \ldots \ldots$

8. People With or Without Health Insurance Coverage by Selected Characteristics: 2004 and $2005 \ldots \ldots 22$

9. People Without Health Insurance Coverage by Race and Hispanic Origin Using

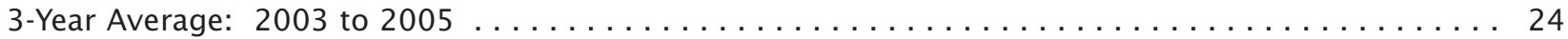

10. Percentage of People Without Health Insurance Coverage by State Using 2- and

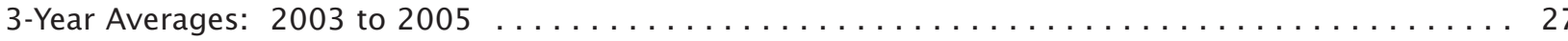

\section{FIGURES}

1. Real Median Household Income: 1967 to $2005 \ldots \ldots \ldots \ldots \ldots \ldots \ldots \ldots \ldots \ldots \ldots \ldots \ldots \ldots$

2. Distribution of All Households and Households in the Lowest and Highest Income Quintiles

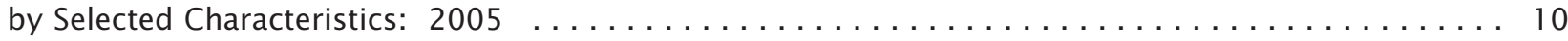

3. Female-to-Male Earnings Ratio and Median Earnings of Full-Time, Year-Round Workers

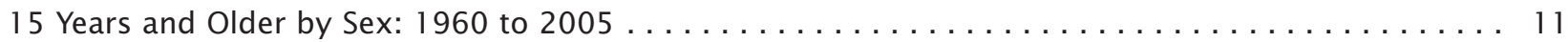

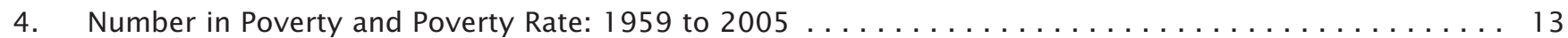

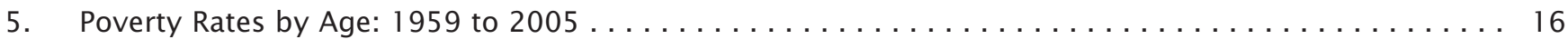

6. Coverage by Type of Health Insurance: 2004 and $2005 \ldots \ldots \ldots \ldots \ldots \ldots \ldots \ldots \ldots \ldots \ldots \ldots \ldots \ldots \ldots$

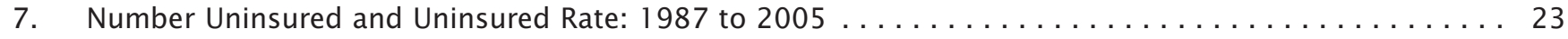

8. Uninsured Children by Poverty Status, Age, and Race and Hispanic Origin: $2005 \ldots \ldots \ldots \ldots$

9. Differences in 2-Year-Average Uninsured Rates by State: 2004-2005 Less 2003-2004 . . . . . . . . . 26

\section{APPENDIXES}

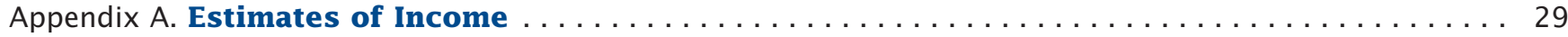

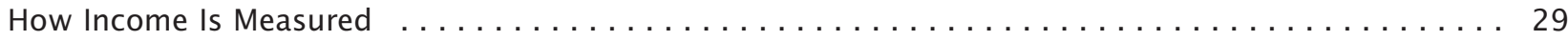

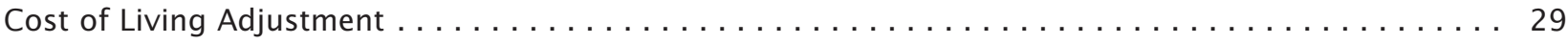

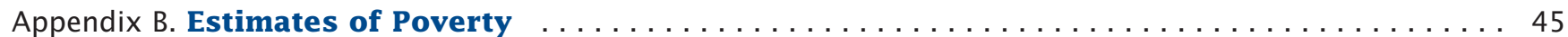

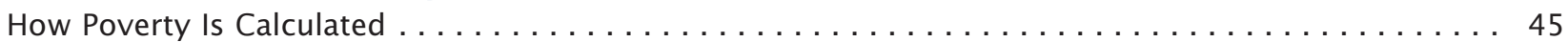

Appendix C. Estimates of Health Insurance Coverage $\ldots \ldots \ldots \ldots \ldots \ldots \ldots \ldots \ldots \ldots \ldots \ldots$

Quality of Health Insurance Coverage Estimates $\ldots \ldots \ldots \ldots \ldots \ldots \ldots \ldots \ldots \ldots \ldots \ldots$

Appendix D. Comparison of State Estimates $\ldots \ldots \ldots \ldots \ldots \ldots \ldots \ldots \ldots \ldots \ldots \ldots \ldots \ldots \ldots$ 


\section{APPENDIX TABLES AND FIGURES}

A-1. Households by Total Money Income, Race, and Hispanic Origin of Householder: 1967 to 2005 . . . . 31

A-2. Real Median Earnings of Full-Time, Year-Round Workers by Sex and Female-to-Male

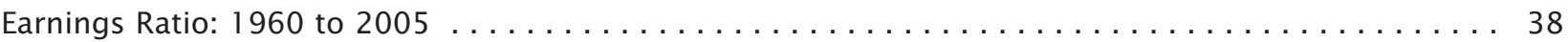

A-3. Selected Measures of Household Income Dispersion: 1967 to $2005 \ldots \ldots \ldots \ldots \ldots \ldots \ldots \ldots \ldots$

B-1. Poverty Status of People by Family Relationship, Race, and Hispanic Origin: 1959 to 2005 . . . . . 46

B-2. Poverty Status of People by Age, Race, and Hispanic Origin: 1959 to $2005 \ldots \ldots \ldots \ldots \ldots \ldots \ldots$

B-3. Poverty Status of Families by Type of Family: 1959 to $2005 \ldots \ldots \ldots \ldots \ldots \ldots \ldots \ldots \ldots \ldots \ldots$

C-1. Health Insurance Coverage by Race and Hispanic Origin: 1987 to $2005 \ldots \ldots \ldots \ldots \ldots \ldots$

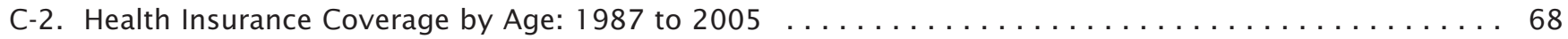

D-1. Three-Year Average Percentage of People Without Health Insurance Coverage

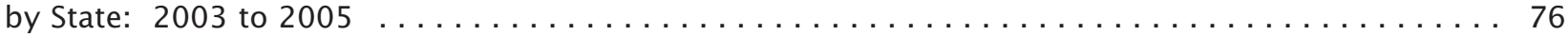




\section{Income, Poverty, and Health Insurance Coverage in the United States: 2005}

\section{INTRODUCTION}

This report presents data on income, poverty, and health insurance coverage in the United States based on information collected in the 2006 and earlier Annual Social and Economic Supplements (ASEC) to the Current Population Survey (CPS) conducted by the U.S. Census Bureau.

Real median household income increased between 2004 and 2005 . $^{2}$ Both the number of people in poverty and the poverty rate were not

This year's report reflects some changes to the 2005 ASEC data due to a correction to the sample weights made after the publication of last year's report. In addition to the weighting correction, the health insurance data from the 2005 ASEC were revised to reflect improvements to the algorithm that assigns coverage to dependents.

All income values are adjusted to reflect 2005 dollars. "Real" refers to income after adjusting for inflation. The adjustment is based on percentage changes in prices between earlier years and 2005 and is computed by dividing the annual average Consumer Price Index Research Series for 2005 by the annual average for earlier years. The CPI-U-RS values for 1947 to 2005 are available in Appendix $A$ and on the Internet at $<$ www.census.gov/hhes/www/income /income05/cpiurs.html>. Inflation between 2004 and 2005 was 3.3 percent. statistically different between 2004 and 2005. The number of people with health insurance coverage increased, while the percentage of people with health insurance coverage decreased between 2004 and 2005. Both the number and the percentage of people without health insurance coverage increased between 2004 and 2005 . These results were not uniform across demographic groups. For example, the poverty rate for non-Hispanic Whites decreased, while the overall rate was statistically unchanged. ${ }^{3}$

\footnotetext{
${ }^{3}$ Federal surveys now give respondents the option of reporting more than one race.

Therefore, two basic ways of defining a race group are possible. A group such as Asian may be defined as those who reported Asian and no other race (the race-alone or single-race concept) or as those who reported Asian regardless of whether they also reported another race (the race-alone-or-in-combination concept). The body of this report (text, figures, and tables) shows data using the first approach (race alone). The appendix tables show data using both approaches. Use of the single-race population does not imply that it is the preferred method of presenting or analyzing data. The Census Bureau uses a variety of approaches.

All comparative statements regarding race in the text are based on the race-alone concept
}

This report has three main sectionsincome, poverty, and health insurance coverage. Each one presents estimates by characteristics such as race, Hispanic origin, nativity, and region. Other topics include earnings of yearround, full-time workers; poverty among families; and health insurance coverage of children. This report also contains data by metropolitan area status, which were not included last year due to the transition from a 1990based sample design to a 2000-based sample design. This year, the report uses a new system of metropolitan and, unless noted to the contrary, are also true in terms of statistical significance for the racealone-or-in-combination concept.

In this report, the term "non-Hispanic White" refers to people who are not Hispanic and who reported White and no other race. The Census Bureau uses non-Hispanic Whites as the comparison group for other race groups and Hispanics.

Because Hispanics may be any race, data in this report for Hispanics overlap with data for racial groups. Being Hispanic was reported by 12.1 percent of White householders who reported only one race, 2.9 percent of Black householders who reported only one race, 27.7 percent of American Indian and Alaska Native householders who reported only one race, and 9.5 percent of Native Hawaiian and Other Pacific Islander householders who reported only one race.

\section{Source of Estimates and Statistical Accuracy}

The data in this report are from the Annual Social and Economic Supplement (ASEC) to the 2006 Current Population Survey (CPS). The population represented (the population universe) is the civilian noninstitutionalized population living in the United States. Members of the Armed Forces living off post or with their families on post are included if at least one civilian adult lives in the household. Most of the data from the CPS ASEC were collected in March (with some data collected in February and April), and the data were controlled to independent population estimates for March 2006.
The estimates in this report (which may be shown in text, figures, and tables) are based on responses from a sample of the population and may differ from actual values because of sampling variability or other factors. As a result, apparent differences between the estimates for two or more groups may not be statistically significant. All comparative statements have undergone statistical testing and are significant at the 90-percent confidence level unless otherwise noted. Further information about the source and accuracy of the estimates is available at <www.census.gov/hhes/www/p60_231sa.pdf>. 
categorization. The data are now presented as inside metropolitan statistical areas, inside principal cities, outside principal cities, and outside metropolitan statistical areas. The report concludes with a section discussing health insurance coverage by state using 2- and 3-year averages.

The income and poverty estimates shown in this report are based solely on money income before taxes and do not include the value of noncash benefits such as food stamps, Medicare, Medicaid, public housing, and employer-provided fringe benefits. Later this year, the Census Bureau will release detailed tables on alternative measures of income and poverty, which include taxes and selected noncash benefits.

The CPS is one of the longest-running surveys conducted by the Census Bureau. The CPS ASEC asks detailed questions categorizing income into over 50 sources. The key purpose of the CPS ASEC is to provide timely and detailed estimates of income, poverty, and health insurance coverage and to measure change in those estimates at the national level. The CPS ASEC is the official source of the national poverty estimates calculated in accordance with the Office of Management and Budget (OMB) Statistical Policy Directive 14 (Appendix B).

\section{State and Local Estimates of Income, Poverty, and} Health Insurance

In previous CPS ASEC reports, the Census Bureau produced state estimates of income and poverty using 2-year and 3-year moving averages. With the expansion of the American Community Survey (ACS) to approximately 3 million addresses in 2005 and the lower standard errors that result from that sample size and design, the Census Bureau is now focusing on annual state estimates of median household income and poverty from the ACS instead of the CPS ASEC. Since 2005 was the first year that the ACS was fully implemented, the Census Bureau will not make comparisons between estimates from the 2005 survey and previous years. This report no longer includes state income and poverty data. Estimates of change in median household income and poverty from the CPS ASEC will continue to be available on the Internet for people interested in trend data at the state level.

While the 2005 ACS has the capability to produce annual income and poverty estimates for counties and places with population of 65,000 or more, the Census Bureau also produces annual estimates of median household income and poverty for states, as well as for counties and school districts, based on models using data from the CPS ASEC, the decennial census, administrative records, and personal income data published by the Bureau of Economic Analysis. The model-based estimates have lower variance than the CPS ASEC estimates but are released later due to lags in the availability of administrative records. Estimates for 2003 are available on the Internet at $<$ www.census.gov/hhes/www/saipe/index.html $>$. Estimates for 2004 will be available in fall 2006.

Since the ACS does not measure health insurance coverage, this report continues to include the state uninsured rates using 2-year and 3-year moving averages. The Census Bureau's Small Area Health Insurance Estimates (SAHIE) program has undertaken a project to estimate health insurance coverage rates for counties. In July 2005, SAHIE released the first estimates ever available on the number of people without health insurance coverage for counties for people of all ages and those under 18 years old. Estimates for calendar year 2000 are available on the Internet at <www.census.gov/hhes/www/sahie/index.html>. 


\section{Dynamics of Economic Well-Being}

The Survey of Income and Program Participation (SIPP) provides monthly data about the labor force participation, income, and health insurance coverage of individuals, families, and households during the time span covered by each of its panels. The data yield insights into the dynamic nature of these experiences and the economic mobility of U.S. residents. Information based on this data is available in a series of reports titled the Dynamics of Economic Well-Being. Topics covered include household income, poverty, health insurance coverage, labor force turnover, unemployment, and program participation. For example, these reports demonstrate that using a longer time frame to measure poverty (e.g., 2 years) yields, on average, a lower poverty rate than the annual measures presented in this report, while using a shorter time frame (e.g., 1 month) yields higher poverty rates.

The Census Bureau is currently undertaking a new project to reengineer the SIPP. The reengineered system, to be known as the Dynamics of Economic Well-Being system, is expected to reduce respondent burden and attrition and to deliver data on a timely basis. Although it will not supply the same level of detail as the SIPP, its design will offer policymakers and researchers data that address the same basic issues. The new system will use data from current demographic surveys, administrative records, and a new demographic survey instrument to identify a population cohort that will be measured longitudinally. A major goal of this new system is to develop monthly estimates of whether and how much individuals participate in cash assistance programs. For further information about the SIPP, copies of these reports, and information about the new system, see <www.sipp.census.gov/sipp $>$.

The Census Bureau also reports on income and poverty based on data from the American Community Survey (ACS). The ACS is part of the 2010 Decennial Census Program and will eliminate the need for a long-form sample questionnaire. The ACS offers broad, comprehensive information on social, economic, and housing data and is designed to provide this information at many levels of geography, particularly for local communities.

Since the CPS ASEC produces the most complete and thorough estimates of income and poverty, the Census Bureau recommends that people use this data source for national estimates. State-level estimates for income and poverty can now be found in the ACS report Income, Earnings, and Poverty Data From the 2005 American Community Survey. Since the ACS does not collect health insurance data, this CPS ASEC report still includes state-level estimates. For more information on state and local estimates, see the text box "State and Local Estimates of Income, Poverty, and Health Insurance."

The CPS ASEC provides reliable estimates of the net change from one year to the next in the overall distribution of economic characteristics of the population, but it does not show how those characteristics change for the same person, family, or household. Longitudinal measures of income, poverty, and health insurance coverage that are based on following the same people over time are available from the Survey of Income and Program Participation (SIPP). Estimates derived from SIPP data answer questions such as:

- What percentage of households move up or down the income distribution over time?

- How many people remain in poverty over time?

- How long do people without health insurance tend to remain uninsured?

The text box "Dynamics of Economic Well-Being" provides more information. 


\section{INCOME IN THE UNITED STATES}

\section{Highlights}

- The real median income of households in the United States rose by 1.1 percent between 2004 and 2005 , from $\$ 45,817$ to $\$ 46,326$ (Figure 1 and Table 1).

- The difference in real median household income between 2004 and 2005 was not statistically significant for each of the race groups shown in Table 1 and for Hispanic households. (Hispanic householders may be any race. $\left.{ }^{4}\right)^{5,6}$

${ }^{4}$ The householder is the person (or one of the people) in whose name the home is owned or rented and the person to whom the relationship of other household members is recorded. If the home is owned jointly by a married couple, either the husband or the wife may be listed as the householder. Since only one person in each household is designated as the householder, the number of householders is equal to the number of households. This report uses the characteristics of the householder to describe the household.

${ }^{5}$ Data users should exercise caution when interpreting aggregate results for the Hispanic population or for race groups because these
- Real median income of households rose in the Northeast (2.9 percent) and in the West ( 1.5 percent)

populations consist of many distinct groups that differ in socioeconomic characteristics, culture, and recency of immigration. In addition, the CPS does not use separate population controls for weighting the Asian sample to national totals. Data were first collected for Hispanics in 1972 and for Asian and Pacific Islanders in 1987. For further information, see $<$ www.bls.census.gov /cps/ads/adsmain.htm>.

${ }^{6}$ Changes in overall median income do not necessarily follow changes experienced by component subgroups because medians do not have the same mathematical properties as other summary measures, such as means.

Figure 1 .

Real Median Household Income: 1967 to 2005

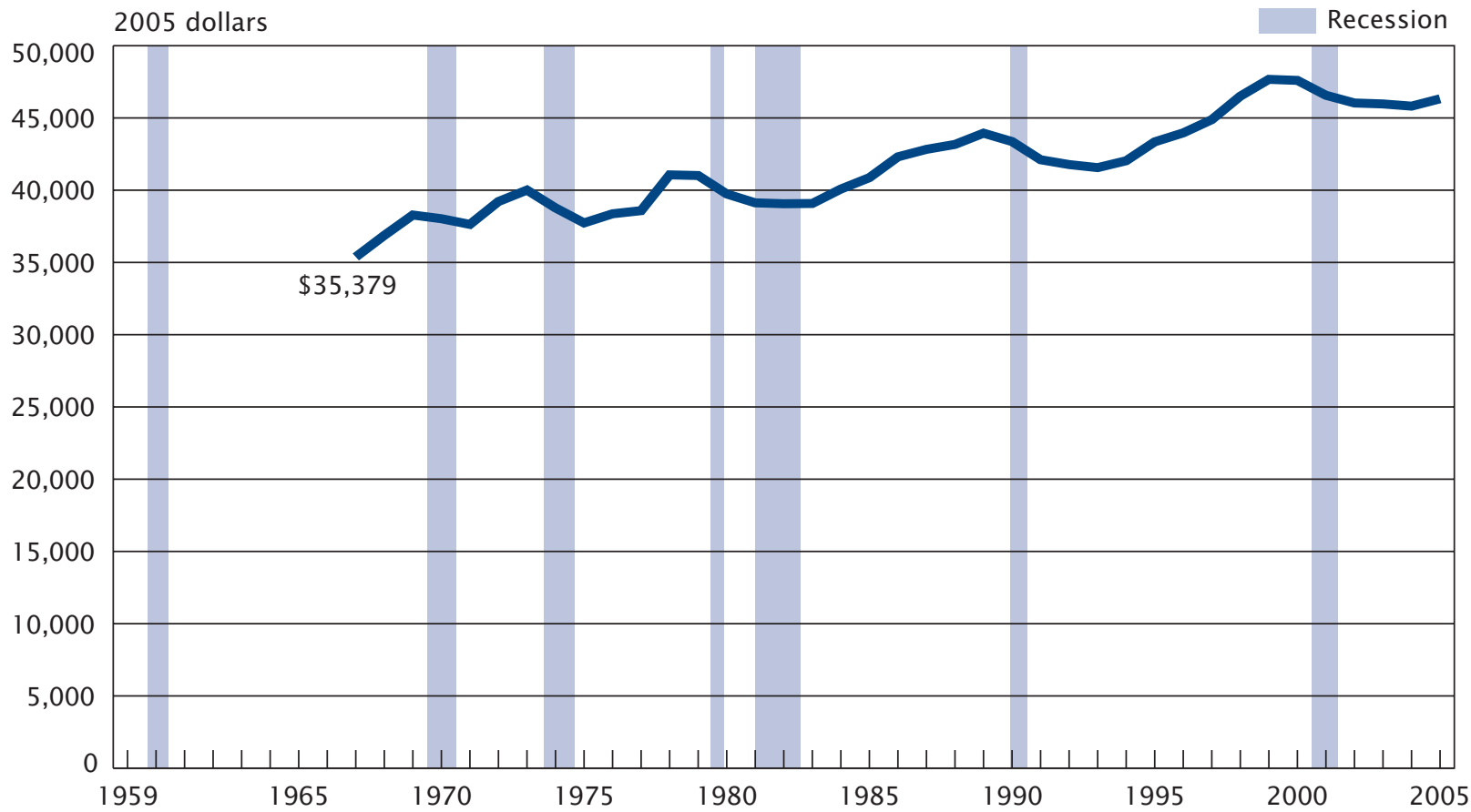

Note: The data points are placed at the midpoints of the respective years. Median household income data are not available before 1967.

Source: U.S. Census Bureau, Current Population Survey, 1968 to 2006 Annual Social and Economic Supplements. 
between 2004 and 2005. The apparent change in the median income of households for the other two regions was not statistically significant (Table 1). ${ }^{7}$

- The apparent change in household income inequality, as measured by the Gini index and the shares of aggregate income received by quintiles, between 2004 and 2005 was not statistically significant (Table 1$){ }^{8}$ Over the past 10 years, the Gini index has increased 4.2 percent.

- The real median earnings of both men and women who worked fulltime, year-round declined between 2004 and 2005 (Table 1). The median earnings of men declined 1.8 percent to $\$ 41,386$. The median earnings of women declined 1.3 percent to $\$ 31,858 .^{9}$

\section{Household Income}

The real median income of households in the United States rose by 1.1 percent between 2004 and 2005, from $\$ 45,817$ to $\$ 46,326$ (Figure 1 and Table 1). The last time median

${ }^{7}$ The Northeast region includes the states of Connecticut, Maine, Massachusetts, New Hampshire, New Jersey, New York, Pennsylvania, Rhode Island, and Vermont. The Midwest region includes the states of Illinois, Indiana, lowa, Kansas, Michigan, Minnesota, Missouri, Nebraska, North Dakota, Ohio, South Dakota, and Wisconsin. The South region includes the states of Alabama, Arkansas, Delaware, Florida, Georgia, Kentucky, Louisiana, Maryland, Mississippi, North Carolina, Oklahoma, South Carolina, Tennessee, Texas, Virginia, West Virginia, and the District of Columbia, a state equivalent. The West region includes the states of Alaska, Arizona, California, Colorado, Hawaii, Idaho, Montana, Nevada, New Mexico, Oregon, Utah, Washington, and Wyoming. The difference between the increases in median household income of the Northeast and the West was not statistically significant.

${ }^{8}$ See the article by Paul Allison, "Measures of Inequality," American Sociological Review, 43. December 1977, pp. 865-880, for an explanation of inequality measures.

9 The difference between the declines in the earnings of men and women was not statistically significant. income of households experienced an annual increase was 1999. Compared with 1967, the first year for which household income statistics are available, real median household income has increased 30.9 percent. ${ }^{10}$

\section{Race and Hispanic Origin}

The apparent change in real median household income between 2004 and 2005 was not statistically significant for each of the race groups shown in Table 1 and for Hispanic households. (Hispanic householders may be any race.) Black households had the lowest median income in 2005, $\$ 30,858$, which was 61 percent of the median for non-Hispanic White households, $\$ 50,784 .{ }^{11}$ Asian households had the highest median income among the race groups. Their 2005 median income was $\$ 61,094$, about 120 percent of the median for non-Hispanic White households. Median income for Hispanic households was $\$ 35,967$ in 2005 , which was 71 percent of the median for non-Hispanic White households.

Table 2 shows income data for the American Indian and Alaska Native population and the Native Hawaiian and Other Pacific Islander population. ${ }^{12}$ Because of the relatively small

${ }^{10}$ Using the CPI-U, instead of the CPI-U-RS, real median household income increased 10.9 percent since 1967 . For a further discussion about the Census Bureau's use of the Consumer Price Index, see Appendixes C and D, Current Population Reports, Series P-60, No. 206, Money Income in the United States: 1998, issued September 1999.

"The distribution of household income is influenced by many factors, such as the number of earners and household size.

${ }_{12}$ Data users should exercise caution when interpreting aggregate results for the American Indian and Alaska Native (AIAN) and the Native Hawaiian and Other Pacific Islander (Pacific Islander) populations because these populations consist of groups that differ in economic characteristics. In addition, the CPS does not use separate population controls for weighting the AIAN and the Pacific Islander samples to national totals. populations of these racial groups, the sampling variability of their income data is larger than for the other racial groups and may cause single-year estimates to fluctuate more widely. To moderate these fluctuations in income, the Census Bureau uses 3-year-average medians when comparing the incomes of the American Indian and Alaska Native and the Native Hawaiian and Other Pacific Islander populations with other racial groups also shown in Table $2 .{ }^{13}$

The 3-year-average (2003-2005) median income for American Indian and Alaska Native households was:

- Higher than the median for Black households.

- Lower than the medians for nonHispanic White households, Asian households, Native Hawaiian and Other Pacific Islander households, and Hispanic households. ${ }^{14}$

The 3-year-average (2003-2005) median income for Native Hawaiian and Other Pacific Islander households was:

- Higher than the medians for Black households, American Indian and Alaska Native households, and Hispanic households.

- Not statistically different from the median for non-Hispanic White households.

- Lower than the median for Asian households.

${ }^{13}$ The 3-year-average median is the sum of three inflation-adjusted (real) single-year medians divided by 3 .

${ }^{14}$ The median income of households whose householder was American Indian and Alaska Native alone or in combination was higher than the median income of households whose householder was American Indian and Alaska Native alone and households whose householder was Hispanic. 
Table 1.

Income and Earnings Summary Measures by Selected Characteristics: 2004 and 2005

(Income in 2005 dollars. Households and people as of March of the following year)

\begin{tabular}{|c|c|c|c|c|c|c|c|c|}
\hline \multirow{3}{*}{ Characteristic } & \multicolumn{3}{|c|}{$2004^{1}$} & \multicolumn{3}{|c|}{2005} & \multicolumn{2}{|c|}{$\begin{array}{l}\text { Percentage change in } \\
\text { real median income } \\
\text { (2005 less 2004) }\end{array}$} \\
\hline & \multirow[b]{2}{*}{$\begin{array}{r}\text { Number } \\
\text { (thousands) }\end{array}$} & \multicolumn{2}{|c|}{$\begin{array}{l}\text { Median income } \\
\quad \text { (dollars) }\end{array}$} & \multirow[b]{2}{*}{$\begin{array}{r}\text { Number } \\
\text { (thousands) }\end{array}$} & \multicolumn{2}{|c|}{$\begin{array}{l}\text { Median income } \\
\quad \text { (dollars) }\end{array}$} & \multirow[b]{2}{*}{ Estimate } & \multirow[b]{2}{*}{$\begin{array}{l}\text { 90-percen } \\
\text { confidence } \\
\text { interval }^{2}( \pm)\end{array}$} \\
\hline & & Estimate & $\begin{array}{r}\text { 90-percent } \\
\text { confidence } \\
\text { interval }^{2}( \pm)\end{array}$ & & Estimate & $\begin{array}{r}90 \text {-percent } \\
\text { confidence } \\
\text { interval }^{2}( \pm)\end{array}$ & & \\
\hline \multicolumn{9}{|l|}{ HOUSEHOLDS } \\
\hline $\begin{array}{l}\text { All households } \ldots \ldots \ldots \ldots \ldots \\
\text { Type of Household }\end{array}$ & 113,343 & 45,817 & 333 & 114,384 & 46,326 & 255 & *1.1 & 0.75 \\
\hline $\begin{array}{l}\text { Family households } \ldots \ldots \ldots \ldots \ldots \ldots \ldots \\
\text { Married-couple } \ldots \ldots \ldots \ldots \ldots \ldots \ldots \\
\text { Female householder, no husband } \\
\text { present } \ldots \ldots \ldots \ldots \ldots \ldots \ldots \ldots \\
\text { Male householder, no wife present } \ldots \\
\text { Nonfamily households } \ldots \ldots \ldots \ldots \ldots \ldots \\
\text { Female householder } \ldots \ldots \ldots \ldots \ldots \ldots \\
\text { Male householder } \ldots \ldots \ldots \ldots \ldots \ldots \\
\text { Race }{ }^{3} \text { and Hispanic Origin of } \\
\text { Householder }\end{array}$ & $\begin{array}{r}76,858 \\
57,975 \\
13,981 \\
4,901 \\
36,485 \\
19,942 \\
16,543\end{array}$ & $\begin{array}{l}57,179 \\
65,946 \\
30,823 \\
46,526 \\
27,129 \\
22,594 \\
33,083\end{array}$ & $\begin{array}{r}338 \\
490 \\
530 \\
1,151 \\
262 \\
321 \\
386\end{array}$ & $\begin{array}{r}77,402 \\
58,179 \\
14,093 \\
5,130 \\
36,982 \\
20,230 \\
16,753\end{array}$ & $\begin{array}{l}57,278 \\
66,067 \\
30,650 \\
46,756 \\
27,326 \\
22,688 \\
34,048\end{array}$ & $\begin{array}{r}332 \\
401 \\
431 \\
1,031 \\
266 \\
413 \\
706\end{array}$ & \begin{tabular}{r|}
0.2 \\
0.2 \\
-0.6 \\
0.5 \\
0.7 \\
0.4 \\
$* 2.9$
\end{tabular} & $\begin{array}{l}0.67 \\
0.78 \\
1.79 \\
2.71 \\
1.12 \\
1.90 \\
2.05\end{array}$ \\
\hline 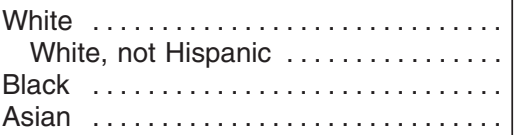 & $\begin{array}{r}92,880 \\
81,628 \\
13,809 \\
4,123\end{array}$ & $\begin{array}{l}48,218 \\
50,546 \\
31,101 \\
59,427\end{array}$ & $\begin{array}{r}311 \\
381 \\
532 \\
2,077\end{array}$ & $\begin{array}{r}93,588 \\
82,003 \\
14,002 \\
4,273\end{array}$ & $\begin{array}{l}48,554 \\
50,784 \\
30,858 \\
61,094\end{array}$ & $\begin{array}{r}349 \\
283 \\
495 \\
1,171\end{array}$ & $\begin{array}{r}0.7 \\
0.5 \\
-0.8 \\
2.8\end{array}$ & $\begin{array}{l}0.78 \\
0.76 \\
1.84 \\
3.42\end{array}$ \\
\hline \multicolumn{9}{|l|}{ Age of Householder } \\
\hline 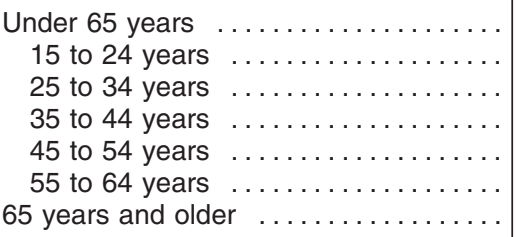 & $\begin{array}{r}90,192 \\
6,733 \\
19,314 \\
23,248 \\
23,393 \\
17,503 \\
23,151\end{array}$ & $\begin{array}{l}52,562 \\
28,497 \\
46,985 \\
58,578 \\
63,068 \\
52,077 \\
25,336\end{array}$ & $\begin{array}{l}253 \\
782 \\
525 \\
551 \\
559 \\
597 \\
296\end{array}$ & $\begin{array}{r}90,926 \\
6,795 \\
19,120 \\
23,016 \\
23,731 \\
18,264 \\
23,459\end{array}$ & $\begin{array}{l}52,287 \\
28,770 \\
47,379 \\
58,084 \\
62,424 \\
52,260 \\
26,036\end{array}$ & $\begin{array}{l}242 \\
776 \\
571 \\
885 \\
724 \\
683 \\
288\end{array}$ & $\begin{array}{r}* 0.5 \\
1.0 \\
0.8 \\
-0.8 \\
-1.0 \\
0.4 \\
{ }^{*} 2.8\end{array}$ & $\begin{array}{l}0.53 \\
3.14 \\
1.34 \\
1.47 \\
1.17 \\
1.41 \\
1.33\end{array}$ \\
\hline \multicolumn{9}{|l|}{ Nativity of Householder } \\
\hline 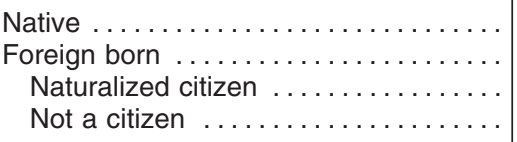 & $\begin{array}{r}98,842 \\
14,502 \\
6,741 \\
7,761\end{array}$ & $\begin{array}{l}46,786 \\
40,692 \\
47,642 \\
35,749\end{array}$ & $\begin{array}{r}304 \\
976 \\
1,448 \\
1,282\end{array}$ & $\begin{array}{r}99,579 \\
14,806 \\
6,990 \\
7,815\end{array}$ & $\begin{array}{l}46,897 \\
42,040 \\
50,030 \\
36,740\end{array}$ & $\begin{array}{r}271 \\
678 \\
1,341 \\
778\end{array}$ & $\begin{array}{r}0.2 \\
* 3.3 \\
* 5.0 \\
2.8\end{array}$ & $\begin{array}{l}0.70 \\
2.46 \\
3.43 \\
3.68\end{array}$ \\
\hline \multicolumn{9}{|l|}{ Region } \\
\hline 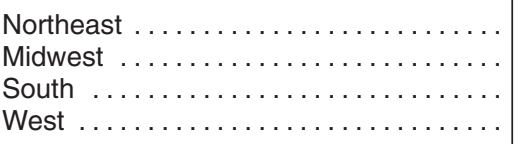 & $\begin{array}{l}21,187 \\
25,939 \\
41,224 \\
24,993\end{array}$ & $\begin{array}{l}49,462 \\
46,134 \\
42,108 \\
49,245\end{array}$ & $\begin{array}{l}819 \\
661 \\
374 \\
668\end{array}$ & $\begin{array}{l}21,054 \\
26,351 \\
41,805 \\
25,174\end{array}$ & $\begin{array}{l}50,882 \\
45,950 \\
42,138 \\
50,002\end{array}$ & $\begin{array}{l}610 \\
579 \\
349 \\
609\end{array}$ & \begin{tabular}{r|}
$* 2.9$ \\
-0.4 \\
0.1 \\
$* 1.5$
\end{tabular} & $\begin{array}{l}1.72 \\
1.54 \\
0.98 \\
1.50\end{array}$ \\
\hline \multicolumn{9}{|l|}{ Residence } \\
\hline $\begin{array}{l}\text { Inside metropolitan statistical areas } \ldots \ldots \\
\text { Inside principal cities } \ldots \ldots \ldots \ldots \ldots \ldots \\
\text { Outside principal cities } \ldots \ldots \ldots \ldots \ldots \\
\text { Outside metropolitan statistical areas }{ }^{4} \ldots\end{array}$ & $\begin{array}{l}(\mathrm{NA}) \\
(\mathrm{NA}) \\
(\mathrm{NA}) \\
(\mathrm{NA})\end{array}$ & $\begin{array}{l}\text { (NA) } \\
\text { (NA) } \\
\text { (NA) } \\
\text { (NA) }\end{array}$ & $\begin{array}{l}(\mathrm{NA}) \\
(\mathrm{NA}) \\
(\mathrm{NA}) \\
(\mathrm{NA})\end{array}$ & $\begin{array}{l}95,107 \\
38,008 \\
57,098 \\
19,278\end{array}$ & $\begin{array}{l}48,474 \\
41,166 \\
53,544 \\
37,564\end{array}$ & $\begin{array}{l}360 \\
354 \\
531 \\
683\end{array}$ & $\begin{array}{l}(X) \\
(X) \\
(X) \\
(X)\end{array}$ & $\begin{array}{l}\text { (X) } \\
\text { (X) } \\
\text { (X) } \\
\text { (X) }\end{array}$ \\
\hline
\end{tabular}

See footnotes at end of table. 
Table 1.

Income and Earnings Summary Measures by Selected Characteristics: 2004 and 2005-Con.

(Income in 2005 dollars. Households and people as of March of the following year)

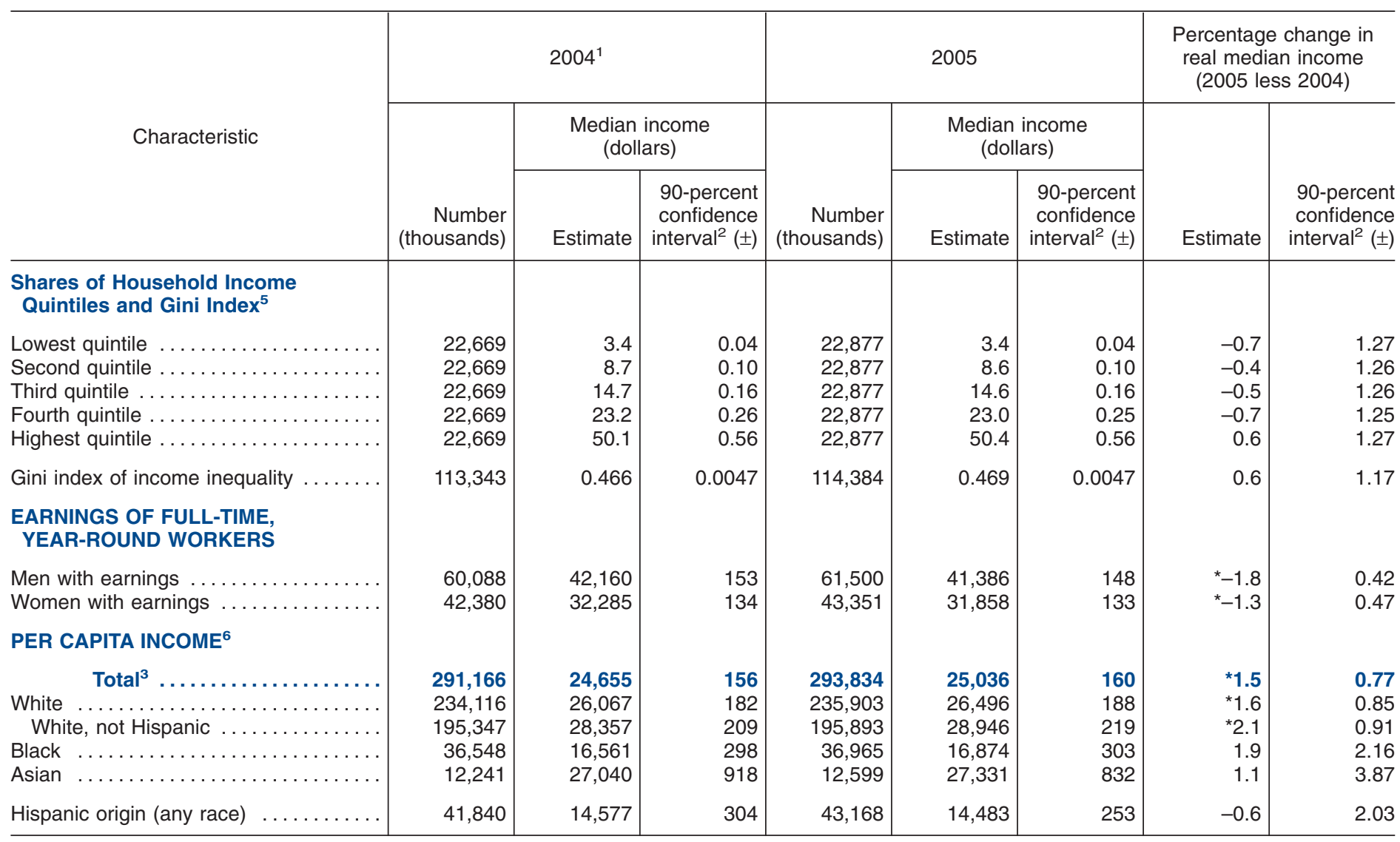

(NA) Not available.

(X) Not applicable.

* Statistically different from zero at the 90-percent confidence level.

1 The 2004 data have been revised to reflect a correction to the weights in the 2005 ASEC.

${ }^{2}$ A 90-percent confidence interval is a measure of an estimate's variability. The larger the confidence interval in relation to the size of the estimate, the less reliable the estimate. For more information, see "Standard Errors and Their Use" at <www.census.gov/hhes/www/income/p60_231sa.pdf>.

${ }^{3}$ Federal surveys now give respondents the option of reporting more than one race. Therefore, two basic ways of defining a race group are possible. A group such as Asian may be defined as those who reported Asian and no other race (the race-alone or single-race concept) or as those who reported Asian regardless of whether they also reported another race (the race-alone-or-in-combination concept). This table shows data using the first approach (race alone). The use of the single-race population does not imply that it is the preferred method of presenting or analyzing data. The Census Bureau uses a variety of approaches. Information on people who reported more than one race, such as White and American Indian and Alaska Native or Asian and Black or African American, is available from Census 2000 through American FactFinder. About 2.6 percent of people reported more than one race in Census 2000.

${ }_{4}^{4}$ The "Outside metropolitan statistical areas" category includes both micropolitan statistical areas and territory outside of metropolitan and micropolitan statistical areas. For more information, see "About Metropolitan and Micropolitan Statistical Areas" at <www.census.gov/population/www/estimates/aboutmetro.html>.

${ }_{5}$ The data shown in this section are shares of aggregate household income, the Gini index, and their respective confidence intervals. See the article by Paul Allison, "Measures of Inequality," American Sociological Review, 43, December 1977, pp. 865-880, for an explanation of inequality measures.

6 The data shown in this section are per capita incomes and their respective confidence intervals. Per capita income is the mean income computed for every man woman, and child in a particular group. It is derived by dividing the total income of a particular group by the total population in that group (excluding patients or inmates in institutional quarters).

Source: U.S. Census Bureau, Current Population Survey, 2005 and 2006 Annual Social and Economic Supplements. 


\section{Nativity}

Real median household income rose by 3.3 percent to $\$ 42,040$ for foreign-born households between 2004 and 2005 (Table 1). The apparent change for native households was not statistically significant. ${ }^{15}$ Among foreign-born households, those maintained by a householder who was a naturalized citizen experienced an increase in median income of 5.0 percent to $\$ 50,030$, which was higher than that of native households $(\$ 46,897){ }^{16}$

\section{Region}

Real median income of households rose in the Northeast (2.9 percent) and in the West ( 1.5 percent) between 2004 and 2005. The apparent change in the median income of households for the other two regions was not statistically significant (Table 1). ${ }^{17}$ The last time the Northeast experienced an annual increase in median household income was in 2000; for the West it was in 1999. In 2005, households in the Northeast had the highest household income $(\$ 50,882)$, followed by households in the West $(\$ 50,002)$ and the Midwest $(\$ 45,950)$. Households in the South had the lowest median income $(\$ 42,138)$.

\footnotetext{
${ }^{15}$ Native households are those in which the householder was born in the United States, Puerto Rico, or certain U.S. island areas (Guam, the Northern Mariana islands, or the Virgin Islands of the United States) or was born in a foreign country but had at least one parent who was a U.S. citizen. All other households are considered foreign born regardless of the date of entry into the United States or citizenship status. The CPS does not interview households in Puerto Rico. Of all households, 87.1 percent were native households, 6.1 percent were households with foreign-born householders who were naturalized citizens, and 6.8 percent were noncitizen households.

${ }^{16}$ The difference between the percent increases in median household income of foreign-born households and households maintained by a naturalized citizen was not statistically significant.

17 The difference between the increases in median household income of the Northeast and the West was not statistically significant.
}

Table 2.

Income of Households by Race and Hispanic Origin Using 3-Year-Average Medians: 2003 to 2005

(Income in 2005 dollars)

\begin{tabular}{|c|c|c|}
\hline \multirow{2}{*}{ Race $^{1}$ and Hispanic origin } & \multicolumn{2}{|c|}{$\begin{array}{l}\text { 3-year-average } \\
\text { median income }^{2} \\
2003-2005^{3} \\
\text { (dollars) }\end{array}$} \\
\hline & Estimate & $\begin{array}{l}\text { 90-percent } \\
\text { confidence } \\
\text { interval }^{4}( \pm)\end{array}$ \\
\hline 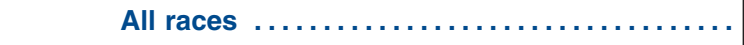 & 46,037 & 216 \\
\hline $\begin{array}{l}\text { White } \ldots \ldots \ldots \ldots \ldots \ldots \ldots \ldots \\
\quad \text { White, not Hispanic } \ldots \ldots \ldots \ldots \ldots \ldots\end{array}$ & $\begin{array}{l}48,399 \\
50,677\end{array}$ & $\begin{array}{l}226 \\
252\end{array}$ \\
\hline Black & 31,140 & 397 \\
\hline American Indian and Alaska Native & 33,627 & 1,680 \\
\hline Asian & 59,877 & 1,239 \\
\hline Native Hawaiian and Other Pacific Islander & 54,318 & 4,183 \\
\hline Hispanic origin (any race) & 35,467 & 521 \\
\hline
\end{tabular}

${ }^{1}$ Federal surveys now give respondents the option of reporting more than one race. Therefore, two basic ways of defining a race group are possible. A group such as Asian may be defined as those who reported Asian and no other race (the race-alone or single-race concept) or as those who reported Asian regardless of whether they also reported another race (the race-alone-or-in-combination concept). This table shows data using the first approach (race alone). The use of the single-race population does not imply that it is the preferred method of presenting or analyzing data. The Census Bureau uses a variety of approaches. Information on people who reported more than one race, such as White and American Indian and Alaska Native or Asian and Black or African American, is available from Census 2000 through American FactFinder. About 2.6 percent of people reported more than one race in Census 2000.

2 The 3-year-average median is the sum of three inflation-adjusted single-year medians divided by 3.

3 The 2004 data have been revised to reflect a correction to the weights in the 2005 ASEC.

${ }^{4}$ A 90-percent confidence interval is a measure of an estimate's variability. The larger the confidence interval in relation to the size of the estimate, the less reliable the estimate. For more information, see "Standard Errors and Their Use" at <www.census.gov/hhes/www/income/p60_231sa.pdf>.

Source: U.S. Census Bureau, Current Population Survey, 2004 to 2006 Annual Social and Economic Supplements.

\section{Income Inequality}

The Gini index, one of the most widely used inequality measures, did not measure a statistically significant change in household income inequality between 2004 and 2005. Over the past 10 years, the Gini index has increased 4.2 percent (from 0.450 to 0.469 ), although the individual annual differences since then were not statistically significant.

(Appendix Table A-3 lists historical inequality measures.) $)^{18}$

The Gini index is computed by using the shares of aggregate income

\footnotetext{
${ }^{8}$ Direct comparisons with years earlier than 1993 are not recommended because of substantial methodological changes in the 1994 ASEC. In that year, the Census Bureau introduced computer-assisted interviewing, increased income reporting limits, and introduced new 1990 decennial-census-based population controls.
}

received by households at various levels in the distribution (e.g., percentiles). The share of aggregate income received by the quintiles can also be used as an inequality measure. The differences between 2004 and 2005 in the shares for each of the five quintiles were not statistically significant. In 2005, the share of aggregate income received by the lowest household income quintile was 3.4 percent. The second quintile received 8.6 percent; the third quintile, 14.6 percent; the fourth quintile, 23.0 percent; and the highest quintile, 50.4 percent.

The ratio of household income at various percentiles can also be used as a measure of income inequality. Between 2004 and 2005, real median income rose by 1.1 percent, the 
Table 3.

Distribution of Households by Selected Characteristics Within Income Quintiles: 2005

(Households as of March 2006)

\begin{tabular}{|c|c|c|c|c|c|c|c|c|}
\hline \multirow[b]{2}{*}{ Characteristic } & \multicolumn{2}{|c|}{ Total households } & \multicolumn{2}{|c|}{ Lowest quintile } & \multicolumn{2}{|c|}{ Middle three quintiles } & \multicolumn{2}{|c|}{ Highest quintile } \\
\hline & Estimate & $\begin{array}{r}\text { 90-percent } \\
\text { confidence } \\
\text { interval }^{1}( \pm)\end{array}$ & Estimate & $\begin{array}{r}90 \text {-percent } \\
\text { confidence } \\
\text { interval }^{1}( \pm)\end{array}$ & Estimate & $\begin{array}{l}\text { 90-percent } \\
\text { confidence } \\
\text { interval }^{1}( \pm)\end{array}$ & Estimate & $\begin{array}{r}\text { 90-percent } \\
\text { confidence } \\
\text { interval }^{1}( \pm)\end{array}$ \\
\hline Total number of households ... & 114,384 & 419 & 22,877 & 252 & 68,630 & 385 & 22,877 & 252 \\
\hline Percent $\ldots \ldots \ldots \ldots \ldots \ldots \ldots \ldots \ldots$ & 100.0 & $(\mathrm{X})$ & 100.0 & $(\mathrm{X})$ & 100.0 & $(\mathrm{X})$ & 100.0 & $(\mathrm{X})$ \\
\hline Upper income limit (dollars) & & $(X)$ & $\$ 19,178$ & 107 & $\$ 91,705$ & 322 & $(\mathrm{NA})$ & $(X)$ \\
\hline \multicolumn{9}{|l|}{ Residence } \\
\hline Inside metropolitan statistical areas ...... & 83.1 & 0.19 & 78.8 & 0.47 & 82.0 & 0.26 & 90.8 & 0.34 \\
\hline Inside principal cities $\ldots \ldots \ldots \ldots \ldots \ldots$ & 33.2 & 0.24 & 39.9 & 0.57 & 32.3 & 0.31 & 29.3 & 0.53 \\
\hline Outside principal cities & 49.9 & 0.26 & 39.0 & 0.57 & 49.7 & 0.34 & 61.5 & 0.57 \\
\hline Outside metropolitan statistical areas ${ }^{2}$ & 16.9 & 0.19 & 21.2 & 0.47 & 18.0 & 0.26 & 9.2 & 0.34 \\
\hline \multicolumn{9}{|l|}{ Region } \\
\hline Northeast & 18.4 & 0.20 & 17.5 & 0.44 & 17.5 & 0.25 & 22.2 & 0.48 \\
\hline Midwest & 23.0 & 0.22 & 22.6 & 0.49 & 23.9 & 0.29 & 20.9 & 0.47 \\
\hline South & 36.5 & 0.25 & 40.2 & 0.57 & 36.8 & 0.32 & 32.0 & 0.54 \\
\hline West . & 22.0 & 0.22 & 19.6 & 0.46 & 21.9 & 0.28 & 24.9 & 0.50 \\
\hline \multicolumn{9}{|l|}{ Type of Household } \\
\hline Family household & 67.7 & 0.24 & 41.0 & 0.57 & 70.0 & 0.31 & 87.5 & 0.38 \\
\hline Married-couple family & 50.9 & 0.26 & 17.9 & 0.45 & 52.5 & 0.33 & 79.0 & 0.47 \\
\hline Female householder, no husband & & & & & & & & \\
\hline present $\ldots \ldots \ldots \ldots$. & 12.3 & 0.17 & 19.7 & 0.46 & 12.4 & 0.22 & 4.8 & 0.25 \\
\hline Male householder, no wife present ..... & 4.5 & 0.11 & 3.4 & 0.21 & 5.1 & 0.15 & 3.6 & 0.22 \\
\hline Nonfamily householder & 32.3 & 0.24 & 59.0 & 0.57 & 30.0 & 0.31 & 12.5 & 0.38 \\
\hline Householder living alone & 26.6 & 0.23 & 55.5 & 0.58 & 23.6 & 0.28 & 6.8 & 0.29 \\
\hline \multicolumn{9}{|l|}{ Age of Householder } \\
\hline 15 to 34 years .... & 22.6 & 0.22 & 23.5 & 0.49 & 25.0 & 0.29 & 14.8 & 0.41 \\
\hline 35 to 54 years ....... & 40.8 & 0.26 & 25.9 & 0.51 & 40.4 & 0.33 & 57.2 & 0.57 \\
\hline 55 to 64 years ......... & 16.0 & 0.19 & 13.5 & 0.40 & 15.5 & 0.24 & 19.7 & 0.46 \\
\hline 65 years and older ...... & 20.5 & 0.21 & 37.1 & 0.56 & 19.0 & 0.26 & 8.3 & 0.32 \\
\hline \multicolumn{9}{|l|}{$\begin{array}{l}\text { Race }^{3} \text { and Hispanic Origin of } \\
\text { Householder }\end{array}$} \\
\hline White & 81.8 & 0.20 & 73.6 & 0.51 & 82.9 & 0.25 & 86.7 & 0.39 \\
\hline White, not Hispanic & 71.7 & 0.23 & 61.4 & 0.57 & 72.0 & 0.30 & 81.2 & 0.45 \\
\hline Black $\ldots \ldots \ldots \ldots \ldots, \ldots, \ldots$ & 12.2 & 0.17 & 20.6 & 0.47 & 11.6 & 0.21 & 5.8 & 0.27 \\
\hline Asian . & 3.7 & 0.10 & 3.0 & 0.20 & 3.3 & 0.12 & 5.8 & 0.27 \\
\hline Hispanic origin (any race) . & 10.9 & 0.16 & 13.4 & 0.40 & 11.8 & 0.22 & 5.9 & 0.27 \\
\hline \multicolumn{9}{|l|}{ Number of Earners } \\
\hline No earners. & 21.2 & 0.21 & 58.7 & 0.57 & 14.9 & 0.24 & 2.6 & 0.18 \\
\hline One earner $\ldots \ldots \ldots \ldots \ldots \ldots \ldots \ldots$ & 36.8 & 0.25 & 35.9 & 0.56 & 42.3 & 0.33 & 21.1 & 0.47 \\
\hline Two or more earners $\ldots \ldots \ldots \ldots \ldots \ldots$ & 42.0 & 0.26 & 5.5 & 0.26 & 42.8 & 0.33 & 76.3 & 0.49 \\
\hline \multicolumn{9}{|l|}{ Work Experience of Householder } \\
\hline Worked & 69.1 & 0.24 & 35.8 & 0.56 & 73.7 & 0.30 & 88.7 & 0.37 \\
\hline Worked full-time, year-round & 50.2 & 0.26 & 14.0 & 0.40 & 54.7 & 0.33 & 73.0 & 0.52 \\
\hline Worked part-time or part-year & 18.9 & 0.20 & 21.9 & 0.48 & 19.0 & 0.26 & 15.7 & 0.42 \\
\hline Did not work $\ldots \ldots \ldots \ldots \ldots \ldots \ldots$ & 30.9 & 0.24 & 64.2 & 0.56 & 26.3 & 0.30 & 11.3 & 0.37 \\
\hline
\end{tabular}

(NA) Not available.

(X) Not applicable.

${ }^{1}$ A 90-percent confidence interval is a measure of an estimate's variability. The larger the confidence interval in relation to the size of the estimate, the less reliable the estimate. For more information, see "Standard Errors and Their Use" at <www.census.gov/hhes/www/income/p60 231sa.pdf $>$.

2 The "Outside metropolitan statistical areas" category includes both micropolitan statistical areas and territory outside of metropolitan and micropolitan statistical areas. For more information, see "About Metropolitan and Micropolitan Statistical Areas" at <www.census.gov/population/www/estimates/aboutmetro.html>.

${ }_{3}$ Federal surveys now give respondents the option of reporting more than one race. Therefore, two basic ways of defining a race group are possible. A group such as Asian may be defined as those who reported Asian and no other race (the race-alone or single-race concept) or as those who reported Asian regardless of whether they also reported another race (the race-alone-or-in-combination concept). This table shows data using the first approach (race alone). The use of the single-race population does not imply that it is the preferred method of presenting or analyzing data. The Census Bureau uses a variety of approaches. Information on people who reported more than one race, such as White and American Indian and Alaska Native or Asian and Black or African American, is available from Census 2000 through American FactFinder. About 2.6 percent of people reported more than one race in Census 2000.

Source: U.S. Census Bureau, Current Population Survey, 2006 Annual Social and Economic Supplement. 
apparent change in real income at the 10 th percentile was not statistically significant, and at the 90th percentile showed an increase of 0.9 percent. Since 1995, real median income has increased 6.9 percent, while income at the 90th percentile has increased 13.0 percent, and income at the 10th percentile has increased 2.3 percent. Similar to the 10-year increase in the Gini index (4.2 percent), the 50thpercentile-to-the-10th-percentile ratio has increased 4.5 percent, while the 90th-percentile-to-the-10th-percentile ratio has increased 10.5 percent. ${ }^{19}$

Table 3 shows the characteristics of all households, and households in the lowest-income quintile, the combined middle three income quintiles, and the highest-income quintile. Households in the lowest quintile had incomes of $\$ 19,178$ or less in 2005 . Households in the combined middle three had incomes from $\$ 19,179$ to $\$ 91,705$, and households in the highest quintile had incomes above \$91,705.

Households were not evenly distributed within quintiles by characteristic. For example, while the majority of households are found in metropolitan areas (83.1 percent), a larger proportion was in the highest quintile group (90.8 percent) than in the lowest quintile group (78.8 percent). More pronounced was the unequal distribution of households found outside the principal cities in metropolitan areas (suburbs). While 49.9 percent of households were in the suburbs, 61.5 percent of the highest-income quintile households were in the suburbs, compared with 39.0 percent of the lowest quintile households.

${ }^{19}$ The differences among the following estimates were not statistically significant: the 2004-2005 change in median household income, the 2004-2005 change in income at the 90th percentile, and the 1995-2005 change in income at the 10th percentile; the 1995-2005 change in income at the 10th percentile, the 1995-2005 changes in the Gini index and the 50th-percentile-to-10th-percentile ratio.
Figure 2.

\section{Distribution of All Households and Households in the Lowest and Highest Income Quintiles by Selected Characteristics: 2005}

(Percent)

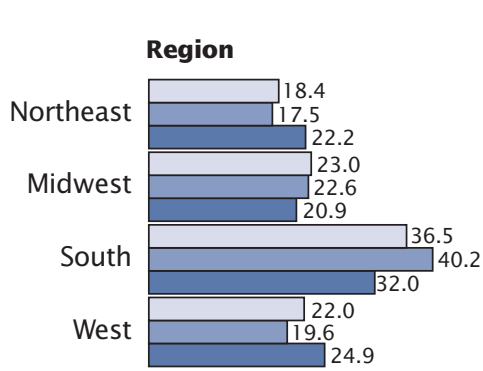

$\square$ Percent of all households

$\square$ Percent of households in the lowest quintile

Percent of households in the highest quintile

Type of household
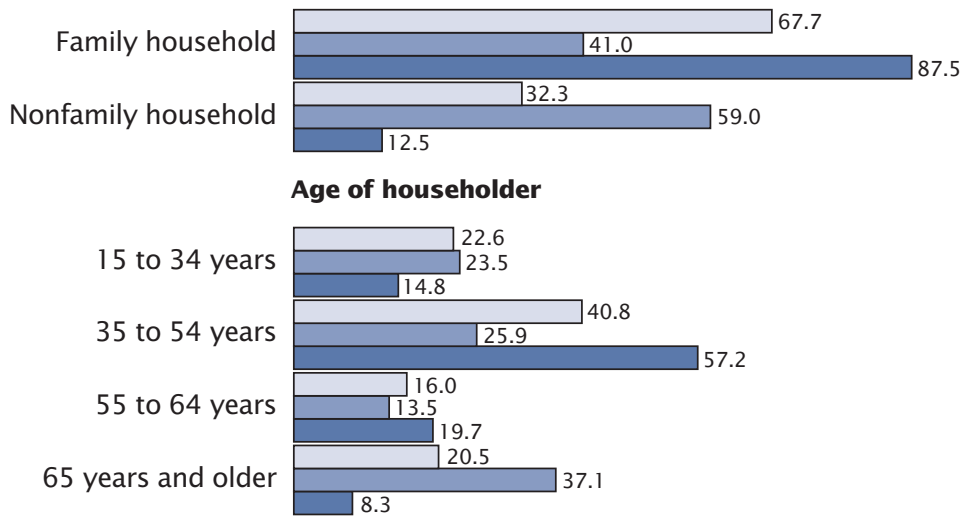

Race and Hispanic origin of householder

White, not Hispanic

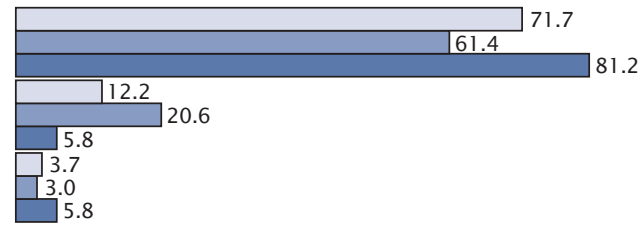

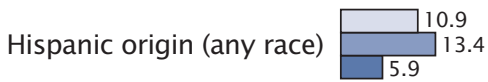

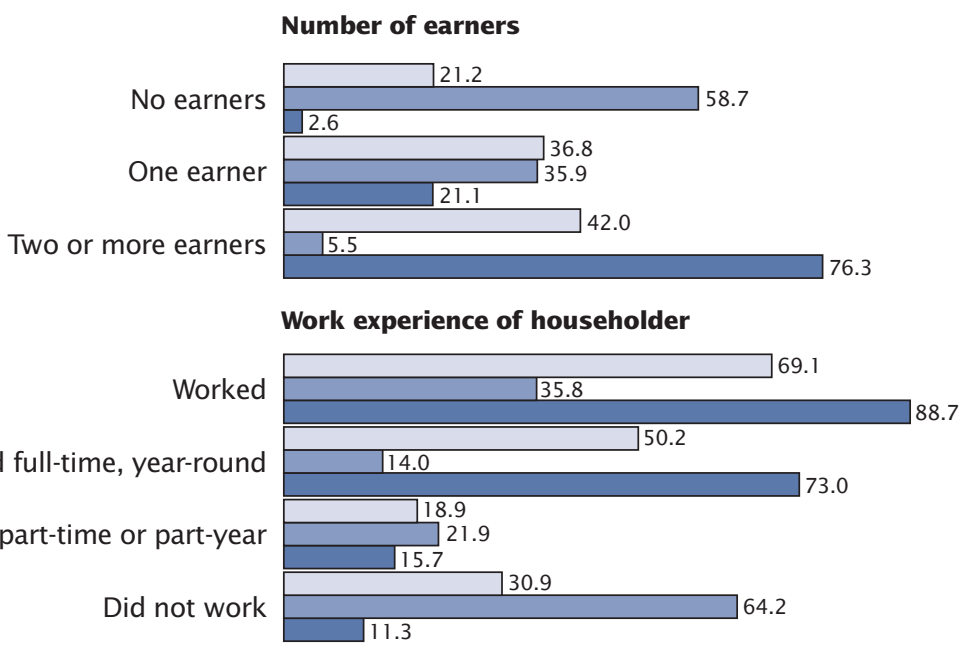

Source: U.S. Census Bureau, Current Population Survey, 2006 Annual Social and Economic Supplement. 
Figure 3.

\section{Female-to-Male Earnings Ratio and Median Earnings of Full-Time, Year-Round Workers 15 Years and Older by Sex: 1960 to 2005}

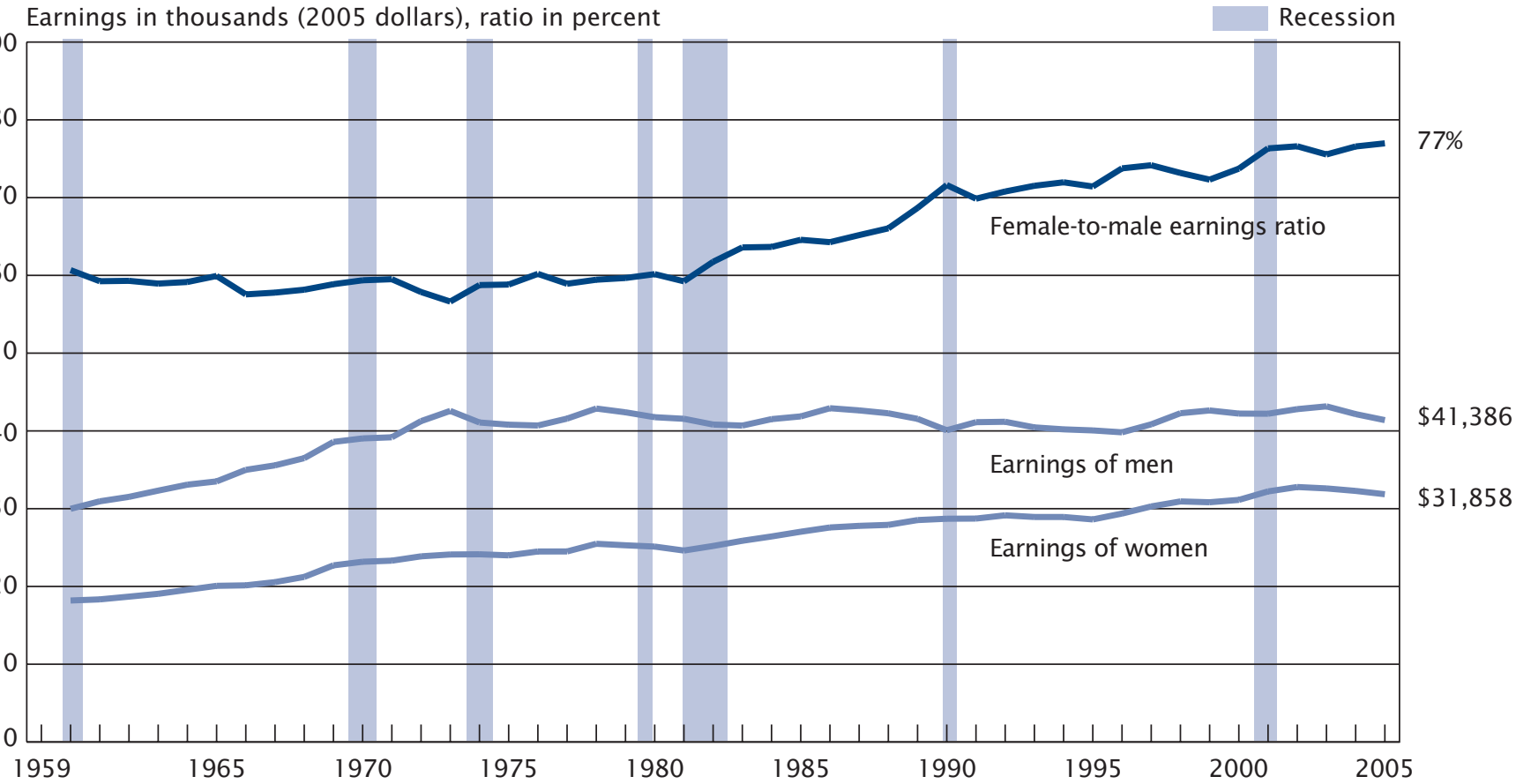

Note: The data points are placed at the midpoints of the respective years. Data on earnings of full-time, year-round workers are not readily available before 1960 .

Source: U.S. Census Bureau, Current Population Survey, 1961 to 2006 Annual Social and Economic Supplements.

Household type also varied by income quintile-the higher the income, the more likely households were to be family households (Table 3 and Figure 2). With 67.7 percent of households made up of families, the highest income quintile consisted of 87.5 percent family households, while the lowest quintile contained 41.0 percent. Conversely, the proportion of nonfamily households was 59.0 percent of households in the lowest quintile and 12.5 percent of households in the highest income quintile. ${ }^{20}$

${ }^{20}$ A family household is a household maintained by a householder who is in a family (and includes any unrelated people who may be residing there). A nonfamily household consists of a householder living alone (a one-person household) or a householder who shares the home exclusively with people to whom he or she is not related.
The race and Hispanic origin of the householder varied by income quintile (Table 3 and Figure 2). Nearly 72 percent of households were nonHispanic White households, 12.2 percent were Black, and 10.9 percent were Hispanic. Non-Hispanic White households represented a larger proportion of households in the highest income quintile (81.2 percent) than in the lowest income quintile (61.4 percent), while Black households and Hispanic households represented a larger proportion of households in the lowest income quintile (20.6 percent and 13.4 percent, respectively) than in the highest (5.8 percent and 5.9 percent, respectively). ${ }^{21}$

${ }^{21}$ The difference between the percentage of households in the highest quintile maintained by Black householders and by Hispanic householders was not statistically significant.
The number of earners and the work experience of the householder were related to the level of household income (Table 3 and Figure 2). The majority of households in the lowest income quintile either had no earner or only one earner (94.6 percent), while 58.0 percent of all households had fewer than two earners. Also, the majority of householders in the lowest quintile did not work or worked part-time or part-year in 2005 (86.1 percent). In contrast, 42.0 percent of all households had two or more earners, with the majority of households in the highest income quintile having two or more earners (76.3 percent) and a working householder (88.7 percent). Among householders in the highest quintile, 73.0 percent worked full-time, year-round. 
Table 3 reflects the fact that peak earnings are most likely to occur in the middle-age years. In 2005, about 40.8 percent of householders were aged 35 to 54 . The highest income quintile was made up of 57.2 percent of householders in this age group, while the lowest quintile had 25.9 percent. This pattern is reversed for the youngest and oldest age groups. Householders aged 15 to 34 or 65 and older composed 43.1 percent of all householders and represented 60.6 percent of households in the lowest quintile and 23.1 percent of households in the highest quintile.

\section{Work Experience and Earnings}

The number of working men aged 15 and older increased by 1.5 million between 2004 and 2005 to 83.0 million. An estimated 74.1 percent worked full-time, year-round, not statistically different from the 2004 estimate. ${ }^{22}$ The number of women workers was 72.5 million, an increase of 0.5 million from 2004. About 59.8 percent of women worked full-time, year-round, a higher percentage than in 2004 (58.8 percent).

Earnings represent the largest component of income; earnings trends and income trends may not be perfectly correlated. While median household income in 2005 rose by 1.1 percent, the real median earnings of both men and women who worked full-time, year-round declined between 2004 and 2005 (Table 1 and Figure 3). The median earnings of men declined 1.8 percent to $\$ 41,386$. The median earnings of women declined 1.3 percent to $\$ 31,858 .{ }^{23}$ This is the second

${ }^{22}$ A full-time, year-round worker is a person who worked 35 or more hours per week (fulltime) and 50 or more weeks during the previous calendar year (year-round). For school personnel, the summer vacation is counted as weeks worked if they are scheduled to return to their job in the fall.

${ }^{23}$ The difference between the declines in the earnings of men and women was not statistically significant. consecutive year that men experienced a decline in earnings and the third consecutive year for women. The female-to-male earnings ratio was .77 in 2005 , not statistically different from the 2004 ratio.

\section{Per Capita Income}

Real per capita income rose by 1.5 percent for the overall population and by 2.1 percent for the non-Hispanic White population between 2004 and 2005. The apparent change in the per capita income of each of the other race groups and Hispanics was not statistically significant. ${ }^{24}$ The per capita income for the overall population in 2005 was $\$ 25,036$; for nonHispanic Whites, it was $\$ 28,946$; for Blacks, \$16,874; for Asians, \$27,331; and for Hispanics, $\$ 14,483$.

${ }^{24}$ The per capita income of the Black alone-orin-combination population increased by 2.2 percent between 2004 and 2005. The differences between the increases in the per capita incomes of the overall population, the non-Hispanic White, and Black alone-or-in-combination populations were not statistically significant. 


\section{POVERTY IN THE UNITED STATES $^{25}$}

\section{Highlights}

- The official poverty rate in 2005 was 12.6 percent, not statistically different from 2004 (Table 4).

- In 2005, 37.0 million people were in poverty, not statistically different from 2004.

- Poverty rates remained statistically unchanged for Blacks (24.9 percent) and Hispanics (21.8 percent) between 2004 and 2005. The poverty rate decreased for nonHispanic Whites (8.3 percent in 2005, down from 8.7 percent in 2004).
${ }^{25}$ OMB determined the official definition of poverty in Statistical Policy Directive 14. Using this definition, the Census Bureau calculates who is in poverty, as described in Appendix B.
- After 4 years of consecutive increases, the poverty rate stabilized at 12.6 percent in 2005higher than the most recent low of 11.3 percent in 2000 and lower than the rate in 1959 (22.4 percent), the first year for which poverty estimates are available (Figure 4).

- The poverty rate in 2005 for children under 18 (17.6 percent) remained higher than that of 18 -to64-year-olds ( 11.1 percent) and that of people 65 and older (10.1 percent)-all were not statistically different from 2004.

- In 2005 , the number in poverty remained statistically unchanged from 2004 for people under 18 and people 18 to 64 years old (12.9 million and 20.5 million, respectively). The number in poverty increased for seniors 65 and older-3.6 million in 2005, up from 3.5 million in 2004.

\section{Race and Hispanic Origin}

Both the poverty rate and the number in poverty for non-Hispanic Whites decreased-8.3 percent and 16.2 million in 2005, down from 8.7 percent and 16.9 million in 2004 (Table 4). The poverty rate for non-Hispanic Whites was lower than for the other racial groups. Non-Hispanic Whites accounted for 43.9 percent of people in poverty and 66.7 percent of the total population. For Blacks, neither the poverty rate (24.9 percent) nor the number in poverty (9.2 million) was statistically different between 2004 and 2005. Among Asians, 11.1 percent were in poverty in 2005 , higher than the 9.8 percent in 2004 .

The number of Asians in poverty also increased-to 1.4 million in 2005 from 1.2 million in 2004. Among Hispanics, neither the poverty rate nor the number in poverty had a statistically significant change between

Figure 4.

Number in Poverty and Poverty Rate: 1959 to 2005

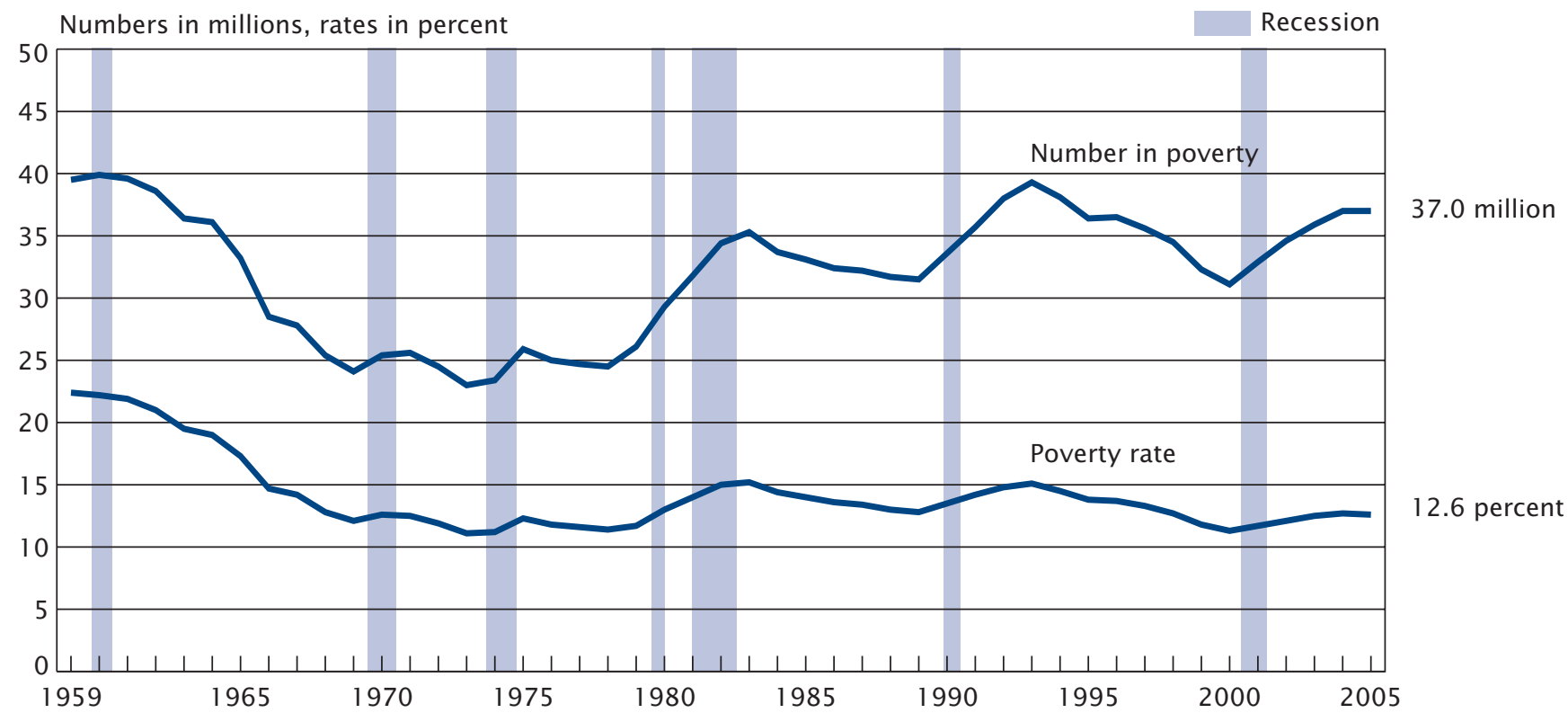

Note: The data points are placed at the midpoints of the respective years.

Source: U.S. Census Bureau, Current Population Survey, 1960 to 2006 Annual Social and Economic Supplements. 
Table 4.

People and Families in Poverty by Selected Characteristics: 2004 and 2005

(Numbers in thousands, confidence intervals (C.I.) in thousands or percentage points as appropriate. People as of March of the following year)

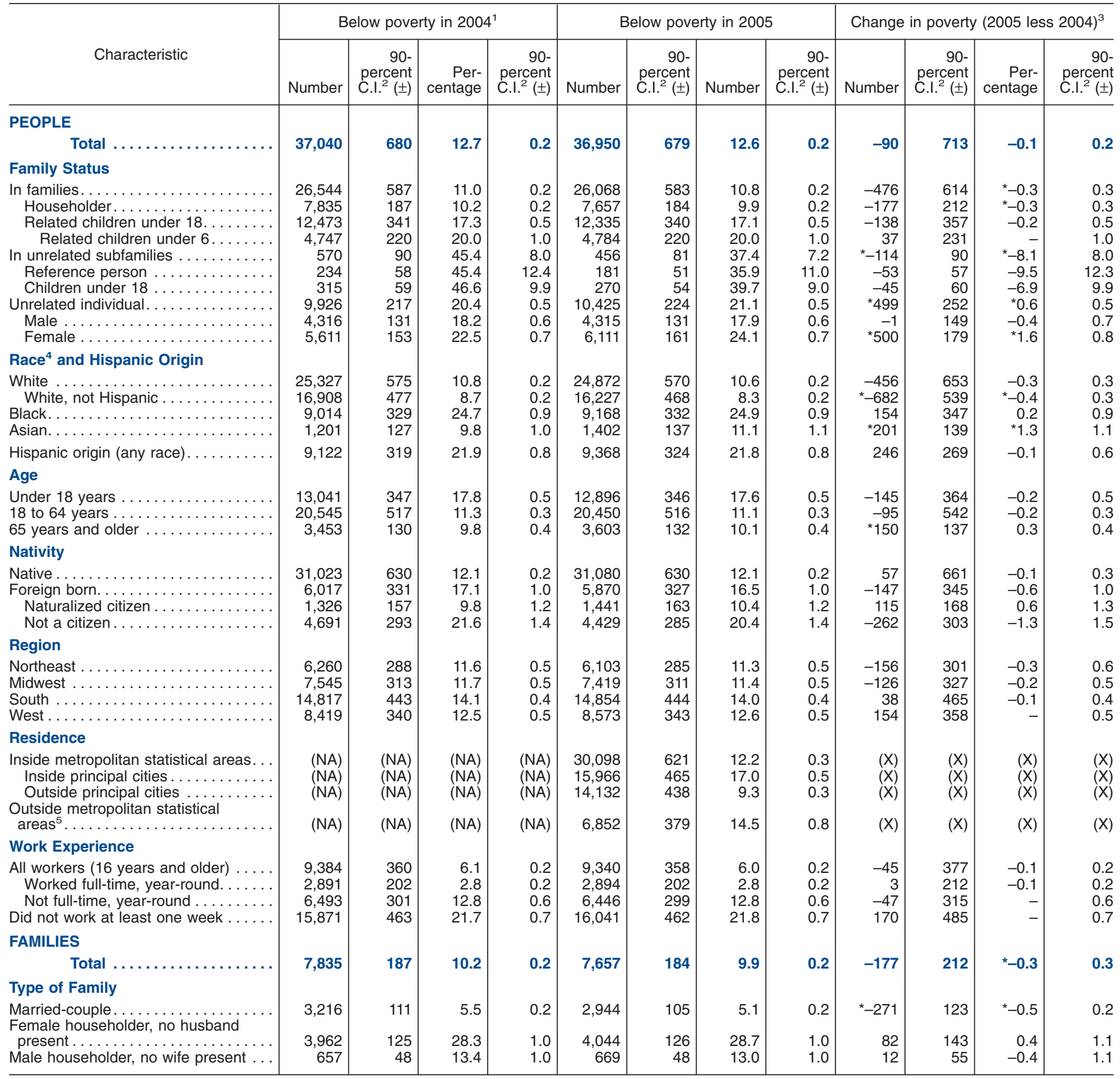

- Represents zero or rounds to zero.

* Statistically different from zero at the 90-percent confidence level. $\quad$ (NA) Not available. $\quad(X)$ Not applicable.

1 The 2004 data have been revised to reflect a correction to the weights in the 2005 ASEC.

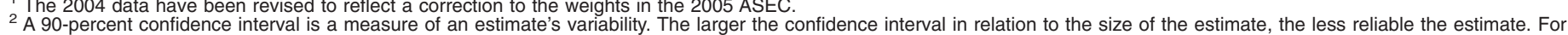
more information, see "Standard Errors and Their Use" at <www.census.gov/hhes/www/p60_231sa.pdf>.

3 Details may not sum to totals because of rounding.

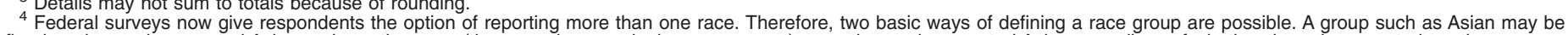

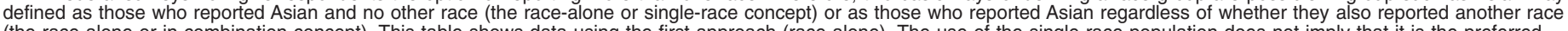

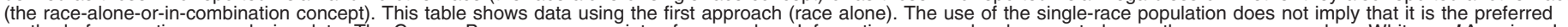

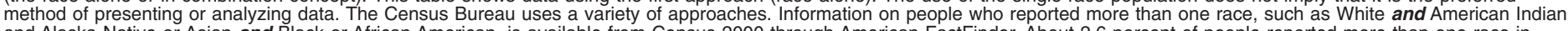

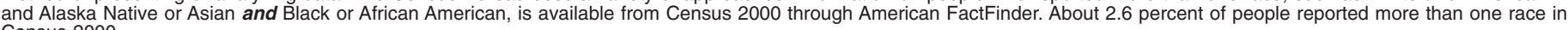
Census 2000.

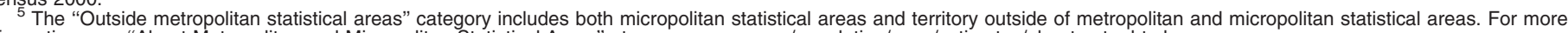
information, see "About Metropolitan and Micropolitan Statistical Areas" at <www.census.gov/population/www/estimates/aboutmetro.html>.

Source: U.S. Census Bureau, Current Population Survey, 2005 and 2006 Annual Social and Economic Supplements. 
Table 5

Number in Poverty and Poverty Rates by Race and Hispanic Origin Using 3-Year Average: 2003 to 2005

(Numbers in thousands. People as of March of the following year)

\begin{tabular}{|c|c|c|c|c|}
\hline \multirow{3}{*}{ Race $^{1}$ and Hispanic origin } & \multicolumn{4}{|c|}{ 3-year average $2003-2005^{2}$} \\
\hline & \multicolumn{2}{|c|}{ Number } & \multicolumn{2}{|c|}{ Percentage } \\
\hline & Estimate & $\begin{array}{r}\text { 90-percent } \\
\text { confidence } \\
\text { interval }^{3}( \pm)\end{array}$ & Estimate & $\begin{array}{r}90-\text { percent } \\
\text { confidence } \\
\text { interval }^{3}( \pm)\end{array}$ \\
\hline 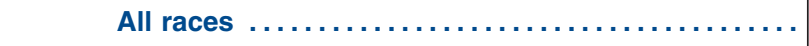 & 36,617 & 494 & 12.6 & 0.2 \\
\hline 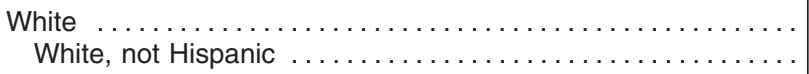 & $\begin{array}{l}24,824 \\
16,346\end{array}$ & $\begin{array}{l}399 \\
329\end{array}$ & $\begin{array}{r}10.6 \\
8.4\end{array}$ & $\begin{array}{l}0.2 \\
0.2\end{array}$ \\
\hline Black & 8,988 & 242 & 24.7 & 0.6 \\
\hline American Indian and Alaska Native & 573 & 65 & 25.3 & 2.5 \\
\hline Asian & 1,335 & 98 & 10.9 & 0.8 \\
\hline Native Hawaiian and Other Pacific Islander & 79 & 24 & 12.2 & 3.6 \\
\hline Hispanic origin (any race) & 9,180 & 252 & 22.0 & 0.6 \\
\hline
\end{tabular}

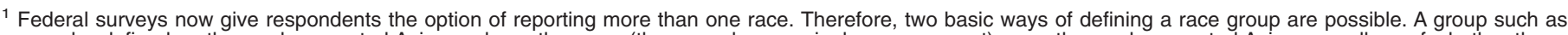

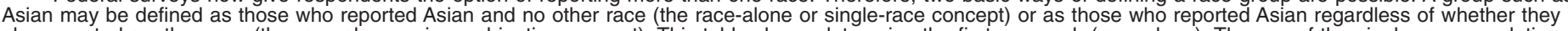

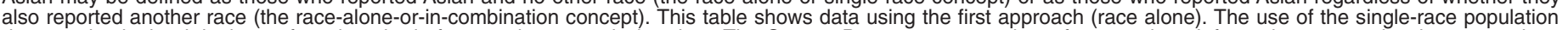

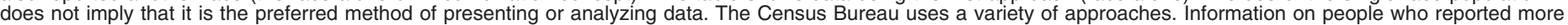

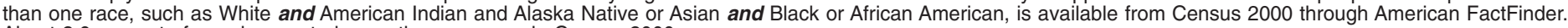
About 2.6 percent of people reported more than one race in Census 2000.

2 The 2004 data have been revised to reflect a correction to the weights in the 2005 ASEC.

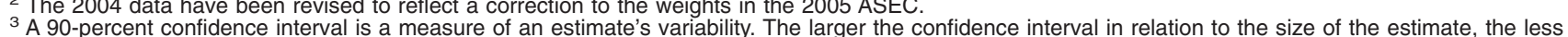
reliable the estimate. For more information, see "Standard Errors and Their Use" at <www.census.gov/hhes/www/p60_231sa.pdf>.

Source: U.S. Census Bureau, Current Population Survey, 2004 to 2006 Annual Social and Economic Supplements.

2004 and 2005, at 21.8 percent and 9.4 million in $2005 .^{26}$

Table 5 displays 3-year averages of the poverty rate and the number in poverty for 2003-2005 for race groups and Hispanics. The 3-yearaverage poverty rate for American Indians and Alaska Natives (25.3 percent) was not statistically different from the rate for Blacks. ${ }^{27}$ It was higher than the rates for other groups. The 3-year-average poverty rate for Native Hawaiians and Other Pacific Islanders (12.2 percent) was lower than the rate for Blacks, American Indians and Alaska Natives, and

${ }^{26}$ The number in poverty for Blacks was not statistically different from that of Hispanics.

${ }^{27}$ The rate for the American Indian and Alaska Native alone-or-in-combination population was statistically lower than that for the American Indian and Alaska Native alone, Black, and Hispanic populations. It was higher than the rates for other groups.
Hispanics; higher than the rate for non-Hispanic Whites; and not statistically different from the rate for Asians.

\section{Age}

Between 2004 and 2005, both the poverty rate and the number in poverty for people 18 to 64 were not statistically different at 11.1 percent and 20.5 million. The number of people 65 and older in poverty increased to 3.6 million in 2005, up from 3.5 million in 2004, while the poverty rate in that age group remained statistically unchanged at 10.1 percent in 2005 (Table 4 and Figure 5).

In 2005, for children under 18, the survey found no statistically significant change in the poverty rate or the number in poverty (17.6 percent and 12.9 million). The poverty rate for children was higher than the rates for people 18 to 64 years old and those 65 and older (Table 4). Children represented 34.9 percent of the people in poverty and 25.0 percent of the total population.

The poverty rate and the number in poverty for related children under 6 living in families were 20.0 percent and 4.8 million, both not statistically different from 2004. Of related children under 6 living in families with female householders with no husband present, 52.9 percent were in poverty, over five times the rate of their counterparts in married-couple families (9.9 percent). For related children under 18 living in families with a female householder with no husband present, 42.8 percent were in poverty, compared with 8.5 percent for married-couple families. 
Figure 5 .

Poverty Rates by Age: 1959 to 2005

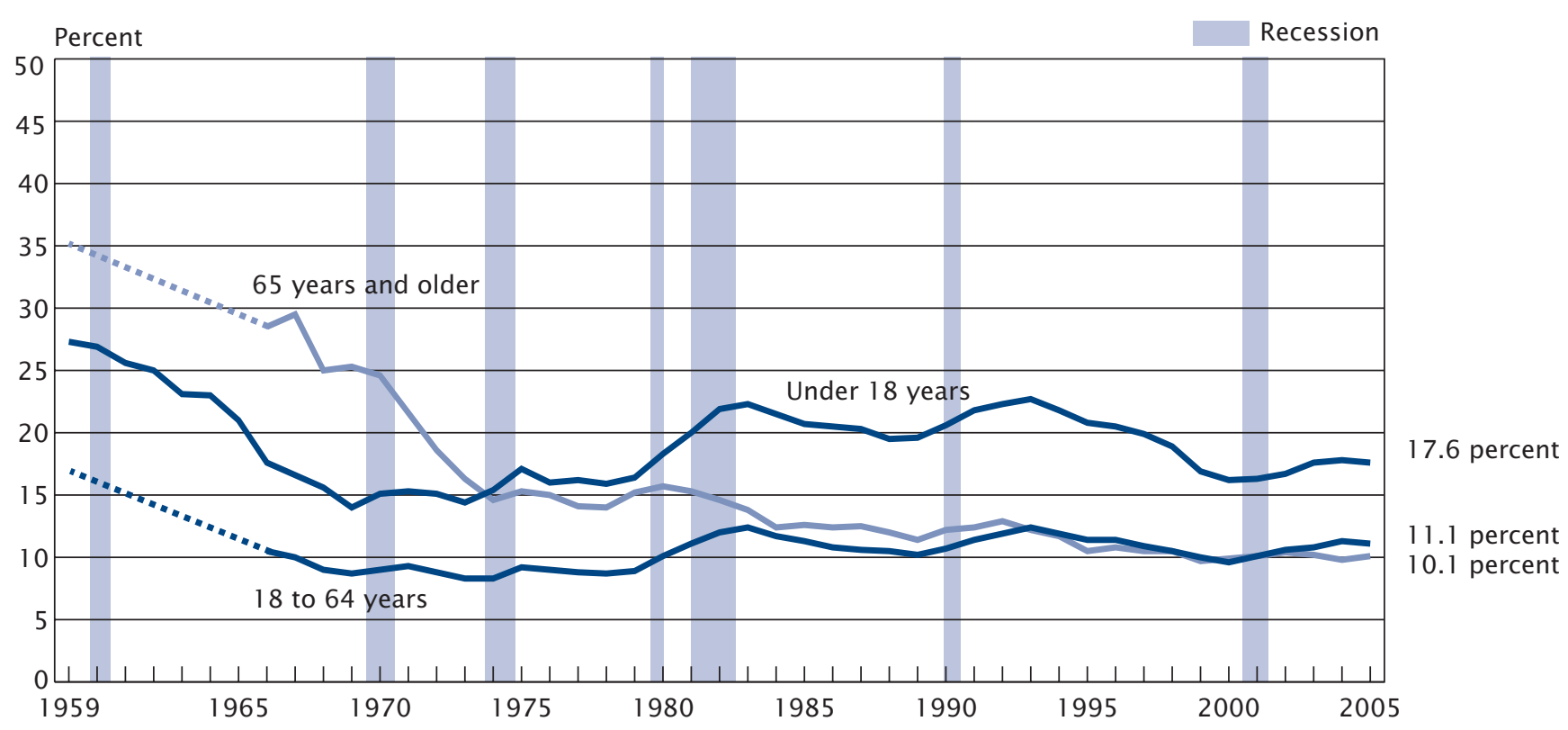

Note: The data points are placed at the midpoints of the respective years.

Data for people 18 to 64 and 65 and older are not available from 1960 to 1965.

Source: U.S. Census Bureau, Current Population Survey, 1960 to 2006 Annual Social and Economic Supplements.

\section{Nativity}

Of all people, 87.8 percent were natives, 4.7 percent were foreignborn naturalized citizens, and 7.4 percent were foreign-born noncitizens. ${ }^{28}$ The poverty rate and the number in poverty for natives and the foreign born were not statistically different from 2004 at 12.1 percent and 31.1 million for natives and 16.5 percent and 5.9 million for the foreign born in 2005 (Table 4).

Of the foreign-born population, 39.0 percent were naturalized citizens; the remaining were noncitizens. Their poverty rates in 2005 were 10.4 percent for foreign-born naturalized citizens and 20.4 percent for those who had not become citizens, both not statistically different from 2004.

${ }^{28}$ Percentages do not sum to 100 because of rounding.

\section{Region}

In 2005 , the poverty rates for the Northeast ( 11.3 percent) and the Midwest ( 11.4 percent) were not statistically different from each other, but were lower than the rates for the South (14.0 percent) and the West (12.6 percent) (Table 4). None of the regions showed any statistical change in either their poverty rate or the number in poverty from 2004 to 2005.

\section{Residence}

In 2005 , the poverty rate among people who lived in metropolitan statistical areas but outside the principal city—suburban areas-(9.3 percent) was lower than the poverty rate among people living in principal cities of metropolitan statistical areas (17.0 percent) and lower than that of people living outside metropolitan statistical areas (14.5 percent).

\section{Work Experience}

People 16 and older who worked some or all of 2005 had a lower poverty rate than those who did not work at any time (6.0 percent compared with 21.8 percent) (Table 4). The poverty rate among full-time, year-round workers ( 2.8 percent) was lower than for those who worked part-time or part-year (12.8 percent) in 2005. In addition, among people 16 and older, those who did not work in 2005 represented 63.2 percent of people in poverty, compared with 32.2 percent of all people.

\section{Families}

In 2005 , the poverty rate for families decreased to 9.9 percent from 10.2 percent in 2004 , while the number of families in poverty remained statistically unchanged at 7.7 million in 2005 (Table 4). 
Table 6.

\section{People With Income Below Specified Ratios of Their Poverty Thresholds by Selected Characteristics: 2005}

(Numbers in thousands, confidence intervals (C.I.) in thousands or percentage points as appropriate. People as of March of the following year)

\begin{tabular}{|c|c|c|c|c|c|c|c|c|c|c|c|c|c|}
\hline \multirow{3}{*}{ Characteristic } & \multirow[b]{3}{*}{ Total } & \multicolumn{12}{|c|}{ Income-to-poverty ratio } \\
\hline & & \multicolumn{4}{|c|}{ Under 0.50} & \multicolumn{4}{|c|}{ Under 1.00} & \multicolumn{4}{|c|}{ Under 1.25} \\
\hline & & $\begin{array}{r}\text { Num- } \\
\text { ber }\end{array}$ & $\begin{array}{r}90- \\
\text { percent } \\
\text { C.I. }{ }^{1}( \pm)\end{array}$ & $\begin{array}{l}\text { Per- } \\
\text { cent }\end{array}$ & $\begin{array}{r}90- \\
\text { percent } \\
\text { C.I. }{ }^{1}( \pm)\end{array}$ & $\begin{array}{l}\text { Num- } \\
\text { ber }\end{array}$ & $\begin{array}{r}90- \\
\text { percent } \\
\text { C.I. }{ }^{1}( \pm)\end{array}$ & $\begin{array}{l}\text { Per- } \\
\text { cent }\end{array}$ & $\begin{array}{r}90- \\
\text { percent } \\
\text { C.I. }{ }^{1}( \pm)\end{array}$ & $\begin{array}{r}\text { Num- } \\
\text { ber }\end{array}$ & $\begin{array}{r}90- \\
\text { percent } \\
\text { C.I. }{ }^{1}( \pm)\end{array}$ & $\begin{array}{l}\text { Per- } \\
\text { cent }\end{array}$ & $\begin{array}{r}90- \\
\text { percent } \\
\text { C.I. }^{1}( \pm)\end{array}$ \\
\hline All people .. & 293,135 & 15,928 & 464 & 5.4 & 0.2 & 36,950 & 679 & 12.6 & 0.2 & 49,327 & 766 & 16.8 & 0.3 \\
\hline \multicolumn{14}{|l|}{ Age } \\
\hline Under 18 years... & 73,285 & 5,648 & 241 & 7.7 & 0.3 & 12,896 & 346 & 17.6 & 0.5 & 16,679 & 382 & 22.8 & 0.5 \\
\hline 18 to 24 years ..... & 27,965 & 2,625 & 115 & 9.4 & 0.4 & 5,094 & 155 & 18.2 & 0.5 & 6,379 & 171 & 22.8 & 0.6 \\
\hline 25 to 34 years... & 39,480 & 2,248 & 109 & 5.7 & 0.3 & 4,965 & 159 & 12.6 & 0.4 & 6,574 & 181 & 16.7 & 0.4 \\
\hline 35 to 44 years. & 43,121 & 1,842 & 99 & 4.3 & 0.2 & 4,186 & 147 & 9.7 & 0.3 & 5,599 & 168 & 13.0 & 0.4 \\
\hline 45 to 54 years ... & 42,797 & 1,494 & 89 & 3.5 & 0.2 & 3,504 & 134 & 8.2 & 0.3 & 4,573 & 152 & 10.7 & 0.3 \\
\hline 55 to 59 years. & 17,827 & 663 & 60 & 3.7 & 0.3 & 1,441 & 87 & 8.1 & 0.5 & 1,923 & 101 & 10.8 & 0.5 \\
\hline 60 to 64 years .... & 13,153 & 498 & 52 & 3.8 & 0.4 & 1,260 & 82 & 9.6 & 0.6 & 1,684 & 94 & 12.8 & 0.7 \\
\hline 65 years and older ...... & 35,505 & 909 & 69 & 2.6 & 0.2 & 3,603 & 132 & 10.1 & 0.4 & 5,917 & 163 & 16.7 & 0.5 \\
\hline \multicolumn{14}{|l|}{$\begin{array}{l}\text { Race }^{2} \text { and Hispanic } \\
\text { Origin }\end{array}$} \\
\hline White & 235,430 & 10,288 & 377 & 4.4 & 0.2 & 24,872 & 570 & 10.6 & 0.2 & 33,864 & 654 & 14.4 & 0.3 \\
\hline White, not Hispanic & 195,553 & 6,916 & 311 & 3.5 & 0.2 & 16,227 & 468 & 8.3 & 0.2 & 22,262 & 542 & 11.4 & 0.3 \\
\hline Black $\ldots \ldots \ldots \ldots$ & 36,802 & 4,302 & 238 & 11.7 & 0.6 & 9,168 & 332 & 24.9 & 0.9 & 11,484 & 362 & 31.2 & 0.9 \\
\hline Asian & 12,580 & 647 & 95 & 5.1 & 0.7 & 1,402 & 137 & 11.1 & 1.1 & 1,909 & 157 & 15.2 & 1.2 \\
\hline Hispanic (any race) & 43,020 & 3,701 & 220 & 8.6 & 0.5 & 9,368 & 324 & 21.8 & 0.8 & 12,582 & 357 & 29.2 & 0.8 \\
\hline \multicolumn{14}{|l|}{ Family Status } \\
\hline In families & 242,389 & 10,573 & 382 & 4.4 & 0.2 & 26,068 & 583 & 10.8 & 0.2 & 35,362 & 667 & 14.6 & 0.3 \\
\hline Householder & 77,418 & 3,230 & 111 & 4.2 & 0.1 & 7,657 & 184 & 9.9 & 0.2 & 10,442 & 225 & 13.5 & 0.2 \\
\hline Related children under & & & & & & & & & & & & & \\
\hline $18 \ldots \ldots \ldots \ldots \ldots$ & 72,095 & 5,209 & 232 & 7.2 & 0.3 & 12,335 & 340 & 17.1 & 0.5 & 16,028 & 377 & 22.2 & 0.5 \\
\hline under $6 \ldots . .$. & 23,914 & 2,127 & 150 & 8.9 & 0.6 & 4,784 & 220 & 20.0 & 0.9 & 6,070 & 245 & 25.4 & 0.9 \\
\hline Unrelated subfamilies & 1,220 & 308 & 66 & 25.2 & 4.7 & 456 & 81 & 37.4 & 5.2 & 568 & 90 & 46.5 & 5.4 \\
\hline Unrelated individual & 49,526 & 5,048 & 143 & 10.2 & 0.2 & 10,425 & 224 & 21.1 & 0.3 & 13,397 & 265 & 27.1 & 0.4 \\
\hline Male & 24,158 & 2,239 & 91 & 9.3 & 0.3 & 4,315 & 131 & 17.9 & 0.5 & 5,564 & 152 & 23.0 & 0.5 \\
\hline Female ..... & 25,367 & 2,809 & 103 & 11.1 & 0.4 & 6,111 & 161 & 24.1 & 0.5 & 7,833 & 187 & 30.9 & 0.5 \\
\hline
\end{tabular}

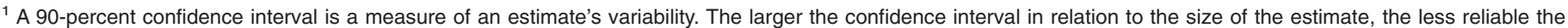
estimate. For more information, see "Standard Errors and Their Use" at <www.census.gov/hhes/www/p60_231sa.pdf>.

2 Federal surveys now give respondents the option of reporting more than one race. Therefore, two basic ways of defining a race group are possible. A group such as

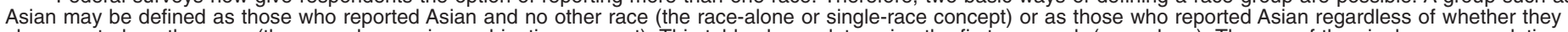

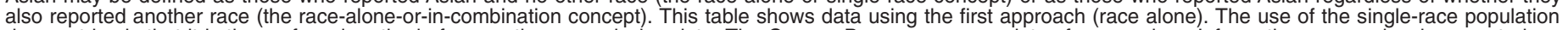

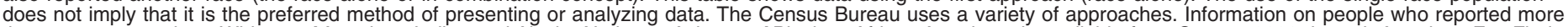

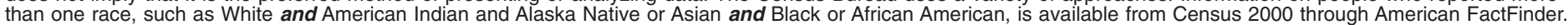
About 2.6 percent of people reported more than one race in Census 2000.

Note: Details may not sum to totals because of rounding.

Source: U.S. Census Bureau, Current Population Survey, 2006 Annual Social and Economic Supplement.

For married-couple families, both the poverty rate and the number in poverty decreased to 5.1 percent and 2.9 million in 2005 , down from 5.5 percent and 3.2 million in 2004 . The poverty rate and the number in poverty showed no statistical difference between 2004 and 2005 for female-householder-with-no-husbandpresent families (28.7 percent and
4.0 million) and for male-householder-with-no-wife-present families (13.0 percent and 669,000).

\section{Depth of Poverty Measures}

Categorizing people as "in poverty" or "not in poverty" is one way to describe their economic situation. The income-to-poverty ratio and the income deficit (surplus) are designed to reflect other aspects of economic well-being. Where the poverty rate provides a measure of the proportion of people with a family income that is below the established poverty thresholds, the income-to-poverty ratio provides a measure to gauge the depth of poverty and to determine the number of people who may be eligible for government-sponsored income 
Table 7.

Income Deficit or Surplus of Families and Unrelated Individuals by Poverty Status: 2005

(Numbers of families and unrelated individuals in thousands, deficits and surpluses and their confidence intervals (C.I.) in dollars)

\begin{tabular}{|c|c|c|c|c|c|c|c|c|c|c|c|c|c|c|c|}
\hline \multirow{2}{*}{ Characteristic } & \multirow[b]{2}{*}{ Total } & \multicolumn{10}{|c|}{ Size of deficit or surplus } & \multicolumn{2}{|c|}{$\begin{array}{l}\text { Average deficit } \\
\text { or surplus }\end{array}$} & \multicolumn{2}{|c|}{$\begin{array}{l}\text { Deficit or } \\
\text { surplus per } \\
\text { capita }\end{array}$} \\
\hline & & $\begin{array}{r}\text { Under } \\
\$ 500\end{array}$ & $\begin{array}{r}\$ 500 \\
\text { to } \\
\$ 999\end{array}$ & $\begin{array}{r}\$ 1,000 \\
\text { to } \\
\$ 1,999\end{array}$ & $\begin{array}{r}\$ 2,000 \\
\text { to } \\
\$ 2,999\end{array}$ & $\begin{array}{r}\$ 3,000 \\
\text { to } \\
\$ 3,999\end{array}$ & $\begin{array}{r}\$ 4,000 \\
\text { to } \\
\$ 4,999\end{array}$ & $\begin{array}{r}\$ 5,000 \\
\text { to } \\
\$ 5,999\end{array}$ & $\begin{array}{r}\$ 6,000 \\
\text { to } \\
\$ 6,999\end{array}$ & $\begin{array}{r}\$ 7,000 \\
\text { to } \\
\$ 7,999\end{array}$ & $\begin{array}{r}\$ 8,000 \\
\text { or } \\
\text { more }\end{array}$ & $\begin{array}{l}\text { Esti- } \\
\text { mate }\end{array}$ & $\begin{array}{r}90- \\
\text { percent } \\
\text { C.I. }{ }^{1}( \pm)\end{array}$ & $\begin{array}{l}\text { Esti- } \\
\text { mate }\end{array}$ & $\begin{array}{r}90- \\
\text { percent } \\
\text { C.I. }{ }^{1}( \pm)\end{array}$ \\
\hline \multicolumn{16}{|l|}{$\begin{array}{l}\text { Below Poverty } \\
\text { Threshold, Deficit }\end{array}$} \\
\hline $\begin{array}{l}\text { All families........... } \\
\text { Married-couple } \\
\text { families........... } \\
\text { Families with a male } \\
\text { householder, no } \\
\text { wife present ....... } \\
\text { Families with a } \\
\text { female householder, } \\
\text { no husband } \\
\text { present............. }\end{array}$ & $\begin{array}{l}7,657 \\
2,944\end{array}$ & $\begin{array}{l}318 \\
142\end{array}$ & $\begin{array}{l}321 \\
156\end{array}$ & $\begin{array}{l}574 \\
279\end{array}$ & $\begin{array}{l}513 \\
205\end{array}$ & $\begin{array}{l}527 \\
238\end{array}$ & 509 & 526 & 466 & 385 & $\begin{array}{l}3,519 \\
1,240\end{array}$ & $\begin{array}{l}8,125 \\
7,632 \\
7,359\end{array}$ & $\begin{array}{l}112 \\
184\end{array}$ & $\begin{array}{l}2,387 \\
2,046 \\
2,546\end{array}$ & 199 \\
\hline $\begin{array}{l}\text { Unrelated individuals... } \\
\quad \text { Male .............. } \\
\text { Female.......... } \\
\text { Above Poverty } \\
\text { Threshold, Surplus }\end{array}$ & $\begin{array}{r}10,425 \\
4,315 \\
6,111\end{array}$ & $\begin{array}{l}853 \\
391 \\
461\end{array}$ & $\begin{array}{l}536 \\
177 \\
358\end{array}$ & $\begin{array}{r}1,161 \\
443 \\
717\end{array}$ & $\begin{array}{r}1,393 \\
544 \\
849\end{array}$ & $\begin{array}{l}907 \\
304 \\
604\end{array}$ & $\begin{array}{l}544 \\
219 \\
325\end{array}$ & $\begin{array}{l}515 \\
236 \\
279\end{array}$ & $\begin{array}{l}403 \\
165 \\
238\end{array}$ & $\begin{array}{l}462 \\
196 \\
266\end{array}$ & $\begin{array}{l}3,652 \\
1,639 \\
2,013\end{array}$ & $\begin{array}{l}5,361 \\
5,605 \\
5,189\end{array}$ & $\begin{array}{l}61 \\
97 \\
79\end{array}$ & $\begin{array}{l}5,361 \\
5,605 \\
5,189\end{array}$ & $\begin{array}{l}153 \\
255 \\
197\end{array}$ \\
\hline $\begin{array}{l}\text { All families........... } \\
\text { Married-couple } \\
\text { families........... } \\
\text { Families with a male } \\
\text { householder, no } \\
\text { wife present ....... } \\
\text { Families with a } \\
\text { female householder, } \\
\text { no husband } \\
\text { present............ }\end{array}$ & $\begin{array}{l}69,761 \\
55,244\end{array}$ & $\begin{array}{l}342 \\
180\end{array}$ & $\begin{array}{r}335 \\
188\end{array}$ & $\begin{array}{l}710 \\
396\end{array}$ & $\begin{array}{l}715 \\
370\end{array}$ & $\begin{array}{l}705 \\
413\end{array}$ & 833 & 771 & 869 & $\begin{array}{l}787 \\
482\end{array}$ & $\begin{array}{l}63,693 \\
51,834\end{array}$ & $\begin{array}{l}63,959 \\
70,824\end{array}$ & $\begin{array}{l}520 \\
612\end{array}$ & \begin{tabular}{|l|}
20,626 \\
22,391
\end{tabular} & $\begin{array}{l}286 \\
313\end{array}$ \\
\hline $\begin{array}{l}\text { Unrelated individuals... } \\
\quad \text { Male } \ldots \ldots \ldots \ldots \ldots \\
\text { Female } \ldots \ldots \ldots \ldots \ldots\end{array}$ & $\begin{array}{l}39,100 \\
19,843 \\
19,257\end{array}$ & $\begin{array}{l}515 \\
162 \\
353\end{array}$ & $\begin{array}{l}579 \\
257 \\
322\end{array}$ & $\begin{array}{r}1,476 \\
662 \\
813\end{array}$ & $\begin{array}{r}1,316 \\
513 \\
803\end{array}$ & $\begin{array}{r}1,229 \\
442 \\
787\end{array}$ & $\begin{array}{r}1,455 \\
697 \\
758\end{array}$ & $\begin{array}{r}1,189 \\
494 \\
695\end{array}$ & $\begin{array}{l}985 \\
410 \\
575\end{array}$ & $\begin{array}{r}1,084 \\
467 \\
618\end{array}$ & $\begin{array}{l}29,272 \\
15,739 \\
13,533\end{array}$ & $\begin{array}{l}29,499 \\
33,933 \\
24,931\end{array}$ & $\begin{array}{l}443 \\
775 \\
406\end{array}$ & $\begin{array}{l}29,499 \\
33,933 \\
24,931\end{array}$ & $\begin{array}{l}586 \\
999 \\
620\end{array}$ \\
\hline
\end{tabular}

${ }^{1}$ A 90 -percent confidence interval is a measure of an estimate's variability. The larger the confidence interval in relation to the size of the estimate, the less reliable the estimate. For more information, see "Standard Errors and Their Use" at <www.census.gov/hhes/www/p60_231sa.pdf>.

Note: Details may not sum to totals because of rounding.

Source: U.S. Census Bureau, Current Population Survey, 2006 Annual Social and Economic Supplement.

assistance programs, such as Temporary Assistance for Needy Families (TANF), Medicare, food stamps, and Low Income Home Energy Assistance Program (LIHEAP).

The income-to-poverty ratio is reported as a percentage that compares a family's income with its poverty threshold, which is based on family size and composition. The income deficit (surplus) tells how many dollars a family's or an unrelated individual's (person who does not live with relatives) income is below (above) its poverty threshold. These measures illustrate how the low-income population varies in relation to the poverty thresholds.

\section{Ratio of Income to Poverty}

Table 6 presents the number and the percentage of people within three ranges of income-to-poverty ratiosthose below 50 percent of poverty ("Under 0.50 "), those below
100 percent of poverty ("Under $1.00, "$ also called "in poverty"), and those below 125 percent of poverty (“Under 1.25").

In 2005 , the percentage and number of people with income below one-half of their poverty thresholds was 5.4 percent and 15.9 million, respectively. This group represented 43.1 percent of the poverty population in 2005 (Table 6). The percentage of people with income below 125 percent of 
their threshold decreased to 16.8 percent in 2005, down from 17.1 percent in 2004, while the number with an income-to-poverty ratio in this range remained statistically unchanged in 2005 at 49.3 million.

The demographic makeup of the population differs at varying degrees of poverty. In 2005 among all people, 5.4 percent were below 50 percent of their threshold, 7.2 percent were above 50 percent and below 100 percent of their threshold, and 4.2 percent were between 100 and 125 percent of their thresholds. The 65-and-older population was more highly concentrated between 100 percent and 125 percent of their poverty thresholds ( 6.5 percent) than below 50 percent of their thresholds (2.6 percent). Among people 65 and older, 10.1 percent were below 100 percent of poverty and 16.7 percent were below 125 percent of poverty, a 65.3 percent difference. The distribution was different for all people12.6 percent were below 100 percent of poverty and 16.8 percent were below 125 percent of poverty, a 33.3 percent difference. ${ }^{29}$

\section{Income Deficit}

The income deficit for families in poverty (the difference in dollars between a family's income and its poverty threshold) averaged $\$ 8,125$ in 2005 (Table 7), not statistically different in real terms from 2004. The average income deficit was larger for families with a female householder with no husband present $(\$ 8,610)$ than for married-couple families $(\$ 7,632)$ and families with a male householder with no wife present $(\$ 7,359) .^{30}$

The income deficit per capita for female-householder families $(\$ 2,647)$

${ }^{29}$ The percentage of people 65 and older who were below 125 percent of their poverty thresholds was not statistically different from the percentage of all people below 125 percent of their poverty threshold.

${ }^{30}$ The average income deficit for marriedcouple families was not statistically different from that of male-householder families. was higher than for married-couple families $(\$ 2,046)$. The income deficit per capita is computed by dividing the average deficit by the average number of people in that type of family. Because families with a female householder with no husband present were smaller, on average, than married-couple families, the larger per capita deficit for female-householder families with no husband present reflects their smaller family size as well as their lower income.

For unrelated individuals in poverty, the average income deficit was $\$ 5,361$ in 2005 . The $\$ 5,189$ deficit for women was lower than the $\$ 5,605$ deficit for men. Because unrelated individuals aged 65 and older have lower poverty thresholds and because there were more unrelated women than men aged 65 and older, the lower average deficit for women reflects differences in age as well as income. 


\section{HEALTH INSURANCE COVERAGE IN THE UNITED STATES}

\section{Highlights}

- The number of people with health insurance coverage increased from 245.9 million in 2004 to 247.3 million in $2005 .^{31}$

- In 2005, 46.6 million people were without health insurance coverage, up from 45.3 million people in 2004 (Table 8).

- The percentage of people without health insurance coverage increased from 15.6 percent in 2004 to 15.9 percent in 2005 .

- The historical record is marked by a 12-year period from 1987 to 1998 when the uninsured rate (12.9 percent in 1987) either increased or was not statistically different from one year to the next (Figure 7). ${ }^{32}$ After peaking at 16.3 percent in 1998, the rate fell for 2 years in a row to 14.2 percent in 2000 . The rate then increased until 2003-2004, where it remained at

${ }^{31}$ The 2004 data have been revised to reflect a correction to the weights in the 2005 ASEC, and the estimates were revised based on improvements to the algorithm that assigns coverage to dependents. For a brief description of how the Census Bureau collects and reports on health insurance, see the text box "What Is Health Insurance Coverage?" For a discussion of the quality of ASEC health insurance coverage estimates, see Appendix C.

32 The year 1987 is the first year for which comparable health insurance coverage statistics are available.

\section{What Is Health Insurance Coverage?}

The Annual Social and Economic Supplement (ASEC) to the Current Population Survey (CPS) asks about health insurance coverage in the previous calendar year. The questionnaire asks separate questions about the major types of health insurance, and people who answer "no" to each of the coverage questions are then asked to verify that they were, in fact, not covered by any type of health insurance. For reporting purposes, the Census Bureau broadly classifies health insurance coverage as private coverage or government coverage. Private health insurance is a plan provided through an employer or a union or purchased by an individual from a private company. Government health insurance includes the federal programs Medicare, Medicaid, and military health care; the State Children's Health Insurance Program (SCHIP); and individual state health plans.* People were considered "insured" if they were covered by any type of health insurance for part or all of the previous calendar year. They were considered "uninsured" if they were not covered by any type of health insurance at any time in that year.

Research shows health insurance coverage is underreported in the CPS ASEC for a variety of reasons. While annual retrospective questions appear to be less of a problem when collecting income data (possibly because the interview period is close to when people pay their taxes), it is probably less than ideal when asking about health insurance coverage. For example, some people may report their insurance coverage status at the time of their interview rather than their coverage status during the previous calendar year. Compared with other national surveys, the CPS ASEC's estimate of the number of people without health insurance more closely approximates the number of people who were uninsured at a specific point in time during the year than the number of people uninsured for the entire year.

For more information on the quality of CPS ASEC health insurance estimates, see Appendix C, "Estimates of Health Insurance Coverage." For a comparison between health insurance coverage rates from the major federal surveys, see How Many People Lack Health Insurance and for How Long? (Congressional Budget Office, May 2003) and People with Health Insurance: A Comparison of Estimates from Two Surveys (Survey of Income and Program Participation Working Paper 243, June 2004).

* Types of insurance are not mutually exclusive and people may be covered by more than one during the year. 
Figure 6.

\section{Coverage by Type of Health Insurance: $2004^{1}$ and 2005}

(Percent)
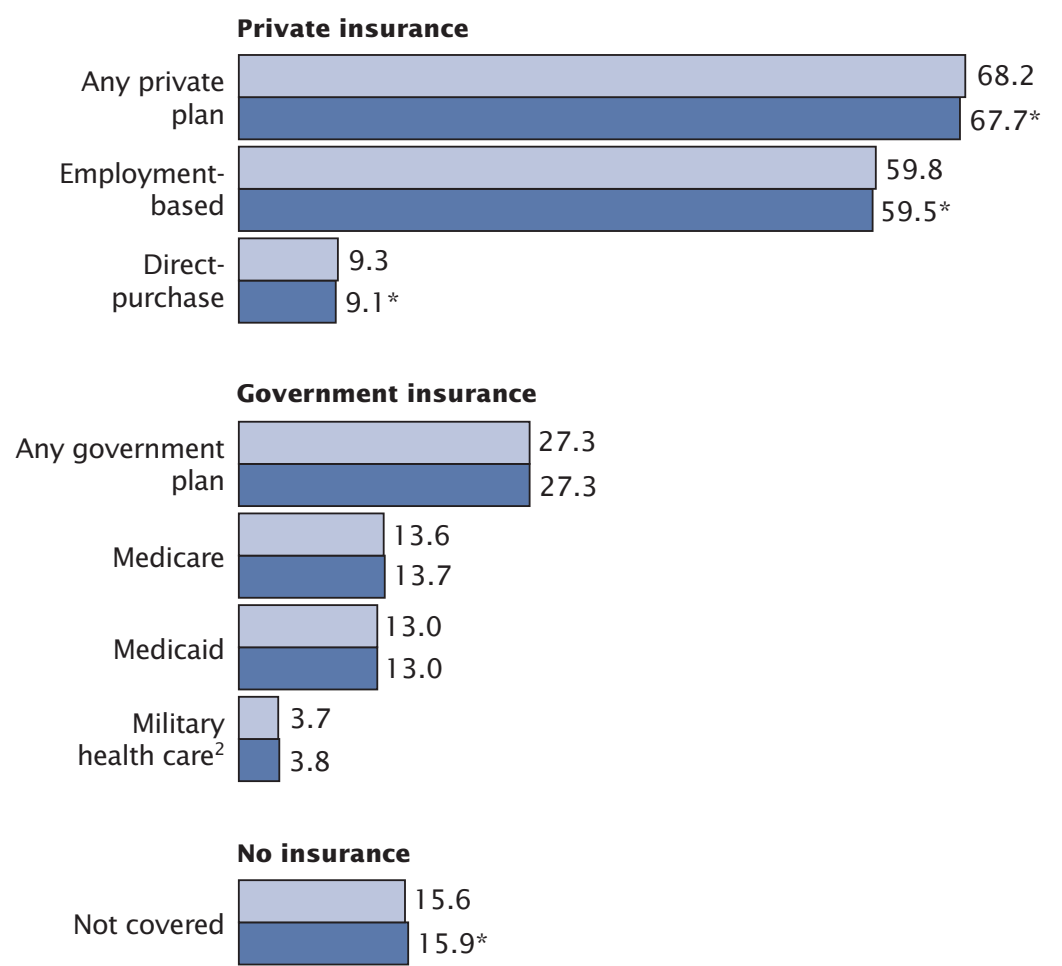

* Statistically different at the 90-percent confidence level.

1 The 2004 data have been revised to reflect a correction to the weights in the 2005 ASEC. The estimates also reflect improvements to the algorithm that assigns coverage to dependents.

${ }^{2}$ Military health care includes CHAMPUS (Comprehensive Health and Medical Plan for Uniformed Services)/Tricare and CHAMPVA (Civilian Health and Medical Program of the Department of Veterans Affairs), as well as care provided by the Department of Veterans Affairs and the military.

Note: The estimates by type of coverage are not mutually exclusive; people can be covered by more than one type of health insurance during the year.

Source: U.S. Census Bureau, Current Population Survey, 2005 and 2006 Annual Social and Economic Supplements.

15.6 percent before it increased to 15.9 percent in $2005 .^{33}$

${ }^{33}$ The difference between the percent uninsured in 1998 and 1997 was not statistically significant.
- The percentage of people covered by employment-based health insurance decreased between 2004 and 2005 , from 59.8 percent to 59.5 percent.
- While the number of people covered by government health programs increased between 2004 and 2005 , from 79.4 million to 80.2 million, the percentage of people covered by government health insurance remained at 27.3 percent. There was no statistical difference in the number or the percentage of people covered by Medicaid (38.1 million and 13.0 percent, respectively) between 2004 and 2005 .

- The percentage and the number of children (people under 18 years old) without health insurance increased between 2004 and 2005, from 10.8 percent to 11.2 percent and from 7.9 million to 8.3 million, respectively (Table 8 ). With an uninsured rate at 19.0 percent in 2005 , children in poverty were more likely to be uninsured than all children (Figure 8).

- The uninsured rate and the number of uninsured remained statistically unchanged from 2004 to 2005 for non-Hispanic Whites (11.3 percent and 22.1 million) and for Blacks (19.6 percent and 7.2 million) (Table 8).

- The number of uninsured increased for Hispanics (from 13.5 million in 2004 to 14.1 million in 2005); their uninsured rate was not statistically different at 32.7 percent in 2005 . 
Table 8.

People With or Without Health Insurance Coverage by Selected Characteristics: 2004 and 2005

(Numbers in thousands, confidence intervals (C.I.) in thousands or percentage points as appropriate. People as of March of the following year)

\begin{tabular}{|c|c|c|c|c|c|c|c|c|c|c|c|c|c|c|}
\hline \multirow{3}{*}{ Characteristic } & \multicolumn{8}{|c|}{ Uninsured } & \multicolumn{6}{|c|}{ Change (2005 less 2004) ${ }^{1}$} \\
\hline & \multicolumn{4}{|c|}{$2004^{2}$} & \multicolumn{4}{|c|}{2005} & \multicolumn{4}{|c|}{ Uninsured } & \multicolumn{2}{|c|}{ Insured } \\
\hline & Number & $\begin{array}{r}90- \\
\text { percent } \\
\text { C.I. }{ }^{3}( \pm)\end{array}$ & $\begin{array}{r}\text { Percent- } \\
\text { age }\end{array}$ & $\begin{array}{r}90- \\
\text { percent } \\
\text { C.I. }{ }^{3}( \pm)\end{array}$ & Number & $\begin{array}{r}90- \\
\text { percent } \\
\text { C.I. } .^{3}( \pm)\end{array}$ & $\begin{array}{r}\text { Percent- } \\
\text { age }\end{array}$ & $\begin{array}{r}90- \\
\text { percent } \\
\text { C.I. }^{3}( \pm)\end{array}$ & Number & $\begin{array}{r}90- \\
\text { percent } \\
\text { C.I. }^{3}( \pm)\end{array}$ & $\begin{array}{r}\text { Percent- } \\
\text { age }\end{array}$ & $\begin{array}{r}90- \\
\text { percent } \\
\text { C.I. }{ }^{3}( \pm)\end{array}$ & Number & $\begin{array}{r}90- \\
\text { percent } \\
\text { C.I. }^{3}( \pm)\end{array}$ \\
\hline \multicolumn{15}{|l|}{ PEOPLE } \\
\hline $\begin{array}{r}\text { Total } \\
\text { Family Status }\end{array}$ & 45,306 & 525 & 15.6 & 0.2 & 46,577 & 530 & 15.9 & 0.2 & *1,272 & 624 & *0.3 & 0.2 & *1,397 & 636 \\
\hline In families & 35,009 & 471 & 14.6 & 0.2 & 36,259 & 478 & 15.0 & 0.2 & *1,160 & 561 & ${ }^{*} 0.4$ & 0.2 & 475 & 789 \\
\hline Householder & 10,557 & 169 & 13.7 & 0.2 & 10,849 & 171 & 14.0 & 0.2 & *292 & 194 & ${ }^{*} 0.3$ & 0.2 & 260 & 410 \\
\hline Related children under $18 \ldots \ldots$ & 7,512 & 229 & 10.4 & 0.3 & 7,784 & 233 & 10.8 & 0.3 & 272 & 274 & ${ }^{*} 0.4$ & 0.4 & -310 & 711 \\
\hline Related children under $6 \ldots \ldots$ & 2,207 & 125 & 9.3 & 0.5 & 2,499 & 133 & 10.4 & 0.5 & *291 & 153 & *1.2 & 0.6 & -129 & 447 \\
\hline In unrelated subfamilies $\ldots \ldots \ldots \ldots$ & 337 & 49 & 26.8 & 3.4 & 382 & 52 & 31.3 & 3.6 & 46 & 60 & *4.5 & 4.1 & -79 & 94 \\
\hline Unrelated individual $\ldots .$. & 9,870 & 262 & 20.1 & 0.5 & 9,936 & 262 & 19.8 & 0.5 & 66 & 310 & -0.3 & 0.6 & *1,001 & 588 \\
\hline \multicolumn{15}{|l|}{ Race $^{4}$ and Hispanic Origin } \\
\hline White $\ldots \ldots \ldots \ldots \ldots \ldots \ldots \ldots$ & 34,447 & 467 & 14.7 & 0.2 & 35,340 & 472 & 15.0 & 0.2 & *893 & 556 & *0.3 & 0.2 & *894 & 803 \\
\hline White, not Hispanic . . . . . . . . & 21,807 & 381 & 11.2 & 0.2 & 22,144 & 383 & 11.3 & 0.2 & 338 & 452 & 0.1 & 0.2 & 208 & 846 \\
\hline Black . . . . . . . . . . . & 7,071 & 253 & 19.3 & 0.7 & 7,228 & 255 & 19.6 & 0.7 & 156 & 300 & 0.2 & 0.8 & 261 & 454 \\
\hline Asian $\ldots \ldots \ldots \ldots \ldots \ldots \ldots$ & 2,016 & 137 & 16.5 & 1.1 & 2,257 & 144 & 17.9 & 1.1 & *241 & 166 & *1.4 & 1.3 & 117 & 272 \\
\hline Hispanic origin (any race) $\ldots \ldots \ldots$ & 13,504 & 307 & 32.3 & 0.7 & 14,122 & 313 & 32.7 & 0.7 & *618 & 325 & 0.4 & 0.8 & ${ }^{\star} 710$ & 326 \\
\hline \multicolumn{15}{|l|}{ Age } \\
\hline Under 18 years $\ldots \ldots \ldots \ldots \ldots$ & 7,949 & 236 & 10.8 & 0.3 & 8,310 & 241 & 11.2 & 0.3 & *361 & 282 & ${ }^{*} 0.5$ & 0.4 & -167 & 716 \\
\hline 18 to 24 years $\ldots \ldots \ldots \ldots \ldots$ & 8,590 & 245 & 30.7 & 0.7 & 8,566 & 244 & 30.6 & 0.7 & -24 & 289 & - & 0.9 & -19 & 427 \\
\hline 25 to 34 years $\ldots \ldots \ldots \ldots \ldots$ & 10,023 & 264 & 25.5 & 0.6 & 10,412 & 268 & 26.4 & 0.6 & *388 & 315 & ${ }^{*} 0.9$ & 0.7 & -218 & 514 \\
\hline 35 to 44 years $\ldots \ldots \ldots \ldots \ldots$ & 8,093 & 238 & 18.7 & 0.5 & 8,090 & 238 & 18.8 & 0.5 & -3 & 281 & 0.1 & 0.6 & -226 & 558 \\
\hline 45 to 64 years & 10,157 & 265 & 14.2 & 0.3 & 10,740 & 273 & 14.6 & 0.3 & *584 & 318 & 0.4 & 0.4 & *1,698 & 702 \\
\hline 65 years and older $\ldots \ldots \ldots \ldots$ & 493 & 59 & 1.4 & 0.2 & 459 & 57 & 1.3 & 0.2 & -33 & 69 & -0.1 & 0.2 & 329 & 556 \\
\hline \multicolumn{15}{|l|}{ Nativity } \\
\hline$\ldots \ldots \ldots \ldots$ & 33,547 & 462 & 13.1 & 0.2 & 34,608 & 468 & 13.4 & 0.2 & *1,062 & 550 & ${ }^{*} 0.3$ & 0.2 & *1,162 & 738 \\
\hline Foreign born & 11,759 & 324 & 33.4 & 0.8 & 11,969 & 327 & 33.6 & 0.8 & 210 & 385 & 0.2 & 0.9 & 235 & 532 \\
\hline Naturalized citizen . . . & 2,290 & 146 & 17.0 & 1.0 & 2,482 & 152 & 17.9 & 1.0 & *192 & 176 & 0.9 & 1.2 & 184 & 377 \\
\hline Not a citizen $\ldots \ldots \ldots \ldots \ldots \ldots$ & 9,469 & 292 & 43.6 & 1.0 & 9,487 & 293 & 43.6 & 1.0 & 18 & 346 & -0.1 & 1.2 & 51 & 392 \\
\hline \multicolumn{15}{|l|}{ Region } \\
\hline Northeast & 6,782 & 211 & 12.6 & 0.4 & 6,657 & 210 & 12.3 & 0.4 & -126 & 249 & -0.3 & 0.5 & *251 & 241 \\
\hline Midwest $\ldots \ldots \ldots \ldots \ldots \ldots$ & 7,757 & 225 & 12.0 & 0.3 & 7,777 & 225 & 11.9 & 0.3 & 19 & 266 & - & 0.4 & 229 & 267 \\
\hline South $\ldots \ldots \ldots \ldots \ldots \ldots \ldots$ & 19,090 & 348 & 18.2 & 0.3 & 19,793 & 353 & 18.6 & 0.3 & *703 & 415 & *0.4 & 0.4 & *575 & 418 \\
\hline West $\ldots \ldots \ldots \ldots \ldots \ldots \ldots$ & 11,676 & 276 & 17.4 & 0.4 & 12,352 & 282 & 18.1 & 0.4 & *675 & 330 & ${ }^{\star} 0.7$ & 0.5 & *342 & 323 \\
\hline \multicolumn{15}{|l|}{ Residence } \\
\hline Inside metropolitan statistical areas . . & $(\mathrm{NA})$ & (NA) & (NA) & (NA) & 39,181 & 494 & 15.9 & 0.2 & $(\mathrm{X})$ & $(\mathrm{X})$ & $(\mathrm{X})$ & $(\mathrm{X})$ & $(\mathrm{X})$ & $(\mathrm{X})$ \\
\hline Inside principal cities $\ldots \ldots \ldots \ldots$ & (NA) & (NA) & (NA) & (NA) & 17,652 & 345 & 18.7 & 0.3 & $(X)$ & $(X)$ & $(\mathrm{X})$ & $(X)$ & $(X)$ & $(X)$ \\
\hline Outside principal cities . . . . . . . & (NA) & (NA) & (NA) & (NA) & 21,528 & 378 & 14.1 & 0.2 & $(X)$ & $(X)$ & $(\mathrm{X})$ & $(\mathrm{X})$ & $(X)$ & $(X)$ \\
\hline $\begin{array}{l}\text { Outside metropolitan statistical } \\
\text { areas }^{5} \ldots \ldots \ldots \ldots \ldots \ldots\end{array}$ & (NA) & (NA) & (NA) & (NA) & 7,397 & 278 & 15.6 & 0.5 & $(\mathrm{X})$ & $(\mathrm{X})$ & $(\mathrm{X})$ & $(\mathrm{X})$ & $(\mathrm{X})$ & $(\mathrm{X})$ \\
\hline \multicolumn{15}{|l|}{ Household Income } \\
\hline Less than $\$ 25,000$ & 15,130 & 321 & 24.3 & 0.5 & 14,561 & 315 & 24.4 & 0.5 & *-569 & 376 & 0.2 & 0.6 & * $-2,173$ & 625 \\
\hline$\$ 25,000$ to $\$ 49,999$ & 14,619 & 316 & 19.8 & 0.4 & 14,977 & 319 & 20.6 & 0.4 & 358 & 376 & *0.8 & 0.5 & * $-1,479$ & 687 \\
\hline$\$ 50,000$ to $\$ 74,999 \ldots \ldots \ldots \ldots$ & 7,688 & 232 & 13.0 & 0.4 & 8,300 & 241 & 14.1 & 0.4 & ${ }^{*} 612$ & 280 & *1.0 & 0.4 & -617 & 651 \\
\hline$\$ 75,000$ or more $\ldots \ldots \ldots \ldots \ldots$ & 7,869 & 234 & 8.2 & 0.2 & 8,740 & 247 & 8.5 & 0.2 & *870 & 285 & ${ }^{*} 0.3$ & 0.3 & *5,665 & 794 \\
\hline \multicolumn{15}{|l|}{ Work Experience } \\
\hline Total, 18 to 64 years old. & 36,864 & 497 & 20.2 & 0.3 & 37,808 & 502 & 20.5 & 0.3 & *944 & 591 & 0.3 & 0.3 & *1,235 & 637 \\
\hline Worked during year ... & 26,546 & 436 & 18.5 & 0.3 & 27,347 & 441 & 18.7 & 0.3 & *802 & 519 & 0.3 & 0.3 & *1,343 & 726 \\
\hline Worked full-time $\ldots \ldots \ldots \ldots \ldots$ & 20,511 & 390 & 17.3 & 0.3 & 21,473 & 398 & 17.7 & 0.3 & *961 & 466 & ${ }^{*} 0.5$ & 0.4 & *1,174 & 746 \\
\hline Worked part-time $\ldots \ldots \ldots \ldots \ldots$ & 6,035 & 220 & 24.2 & 0.8 & 5,875 & 217 & 23.5 & 0.8 & -160 & 259 & -0.6 & 0.9 & 169 & 446 \\
\hline Did not work $\ldots \ldots \ldots \ldots \ldots \ldots$ & 10,318 & 285 & 26.9 & 0.7 & 10,461 & 287 & 27.3 & 0.7 & 143 & 338 & 0.5 & 0.8 & -108 & 527 \\
\hline
\end{tabular}

- Represents zero or rounds to zero.

* Statistically different from zero at the 90-percent confidence level. $\quad$ (NA) Not available. $\quad$ (X) Not applicable.

1 Details may not sum to totals because of rounding.

2 The 2004 data have been revised to reflect a correction to the weights in the 2005 ASEC. The estimates also reflect improvements to the algorithm that assigns coverage to dependents.

${ }^{3} \mathrm{~A} 90$-percent confidence interval is a measure of an estimate's variability. The larger the confidence interval in relation to the size of the estimate, the less reliable the estimate. For more information, see "Standard Errors and Their Use" at <www.census.gov/hhes/www/p60_231sa.pdf>.

${ }_{4}$ Federal surveys now give respondents the option of reporting more than one race. Therefore, two basic ways of defining a race group are possible. A group such as Asian may be defined as those who reported Asian and no other race (the race-alone or single-race concept) or as those who reported Asian regardless of whether they also reported another race (the race-alone-or-in-

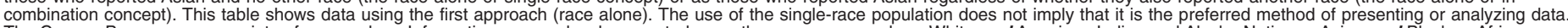
The Census Bureau uses a variety of approaches. Information on people who reported more than one race, such as White and American Indian and Alaska Native or Asian and Black or African

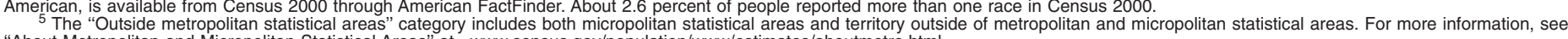
"About Metropolitan and Micropolitan Statistical Areas" at <www.census.gov/population/www/estimates/aboutmetro.html>

Source: U.S. Census Bureau, Current Population Survey, 2005 and 2006 Annual Social and Economic Supplements. 
Figure 7.

Number Uninsured and Uninsured Rate: 1987 to 2005

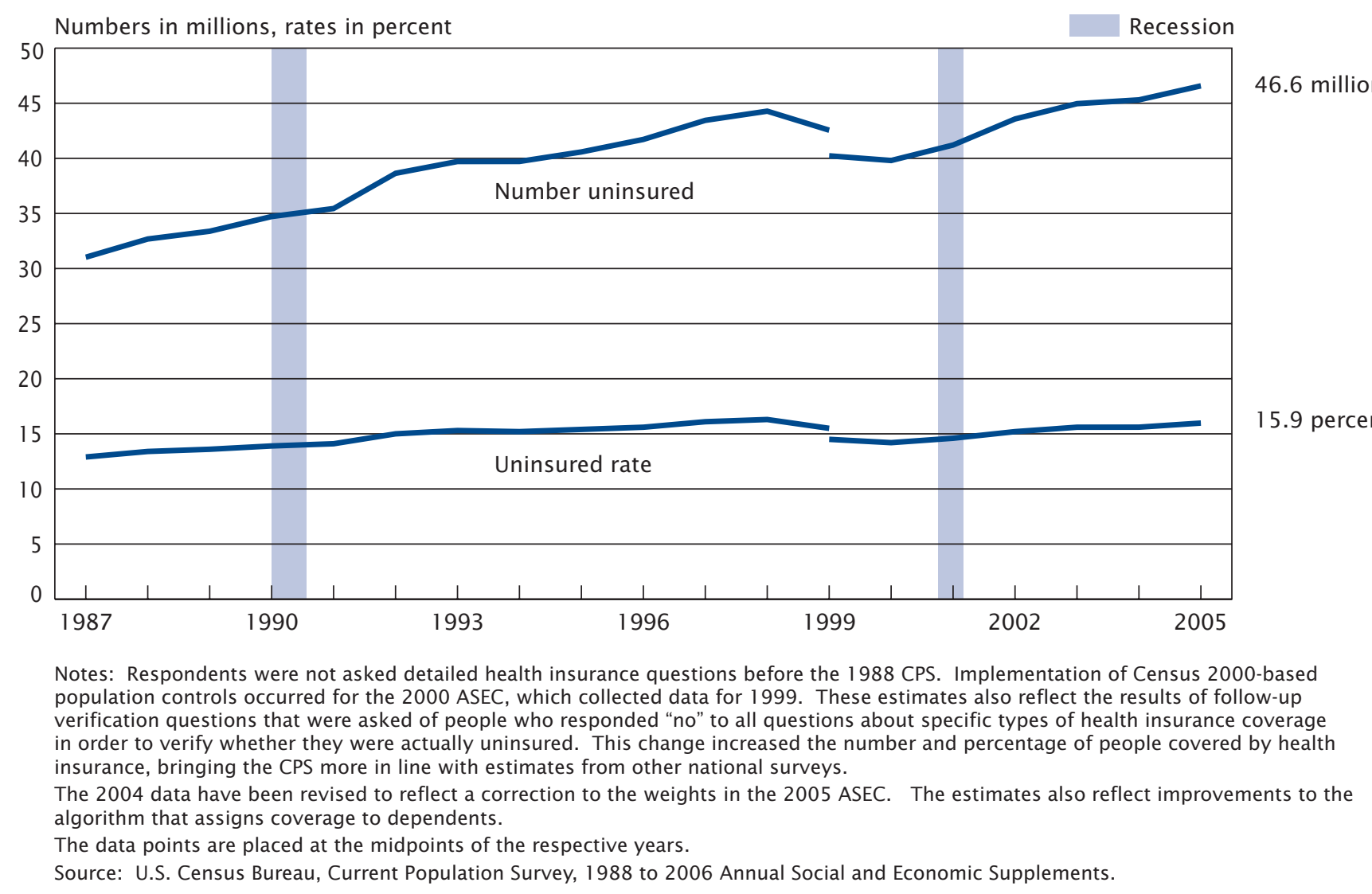

\section{Type of Coverage}

Most people (59.5 percent) were covered by a health insurance plan related to employment for some or all of 2005, a smaller proportion than in the previous year (59.8 percent). As the largest component of private health insurance coverage, this decline in employment-based coverage essentially explains the decrease in total private health insurance coverage, from 68.2 percent in 2004 to 67.7 percent in 2005 (Figure 6).

The number of people covered by government health programs increased between 2004 and 2005, from 79.4 million to 80.2 million, while the percentage of people covered by government health insurance was not statistically different at 27.3 percent. The percentage of people with Medicaid coverage (13.0 percent) and the percentage of people covered by Medicare (13.7 percent) both were not statistically different between 2004 and 2005.

\section{Race and Hispanic Origin}

In 2005, the uninsured rates for nonHispanic Whites at 11.3 percent and for Blacks at 19.6 percent were not statistically different from 2004 (Table 8). The rate for Asians increased to 17.9 percent in 2005 , from 16.5 percent in 2004, but the 2005 rate was not statistically different from 2003. Among Hispanics, the uninsured rate was statistically unchanged at 32.7 percent, while the number of Hispanics without coverage increased from 13.5 million in 2004 to 14.1 million in 2005 .

Table 9 displays the 3-year average (2003-2005) for people without health insurance coverage by race and Hispanic origin. American Indians and Alaska Natives had a 3year-average (2003-2005) uninsured rate (29.9 percent) that was higher than the rate for Native Hawaiians and Other Pacific Islanders (21.8 percent) and higher than those of other race groups. The 3-year average also shows that American Indians and Alaska Natives had an uninsured rate that was lower than the uninsured rate for Hispanics (32.6 percent). 
Table 9. People Without Health Insurance Coverage by Race and Hispanic Origin Using 3-Year Average:
2003 to 2005

(Numbers in thousands. People as of March of the following year)

\begin{tabular}{|c|c|c|c|c|}
\hline \multirow{3}{*}{ Race $^{1}$ and Hispanic origin } & \multicolumn{4}{|c|}{ 3-year average $2003-2005^{2}$} \\
\hline & \multicolumn{2}{|c|}{ Number } & \multicolumn{2}{|c|}{ Percentage } \\
\hline & Estimate & $\begin{array}{r}\text { 90-percent } \\
\text { confidence } \\
\text { interval }^{3}( \pm)\end{array}$ & Estimate & $\begin{array}{r}\text { 90-percent } \\
\text { confidence } \\
\text { interval }^{3}( \pm)\end{array}$ \\
\hline All races $\ldots \ldots \ldots \ldots \ldots \ldots \ldots$ & 45,615 & 359 & 15.7 & 0.1 \\
\hline $\begin{array}{l}\text { White } \ldots \ldots \ldots \ldots \ldots \ldots \\
\quad \text { White, not Hispanic ....... }\end{array}$ & $\begin{array}{l}34,590 \\
21,844\end{array}$ & $\begin{array}{l}320 \\
260\end{array}$ & $\begin{array}{l}14.8 \\
11.2\end{array}$ & $\begin{array}{l}0.1 \\
0.1\end{array}$ \\
\hline Black & 7,126 & 173 & 19.5 & 0.5 \\
\hline American Indian and Alaska Native & 681 & 56 & 29.9 & 2.1 \\
\hline Asian & 2,167 & 96 & 17.7 & 0.8 \\
\hline Native Hawaiian and Other Pacific Islander .... & 139 & 26 & 21.8 & 3.6 \\
\hline Hispanic origin (any race) & 13,621 & 225 & 32.6 & 0.5 \\
\hline
\end{tabular}

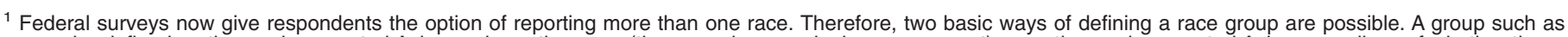

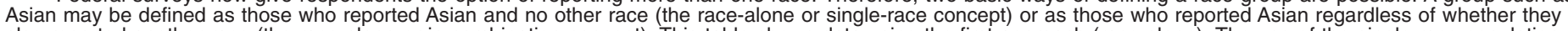

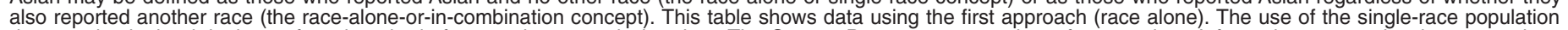

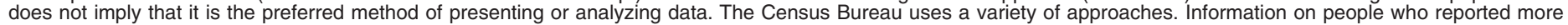

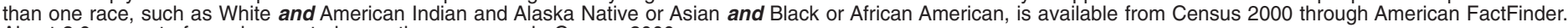
About 2.6 percent of people reported more than one race in Census 2000.

2 The 2004 data have been revised to reflect a correction to the weights in the 2005 ASEC. The estimates also reflect improvements to the algorithm that assigns coverage to dependents.

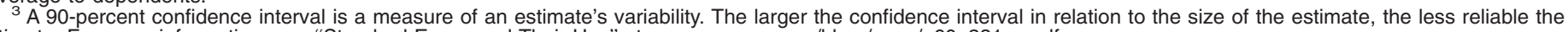
estimate. For more information, see "Standard Errors and Their Use" at <www.census.gov/hhes/www/p60_231sa.pdf>.

Source: U.S. Census Bureau, Current Population Survey, 2004 to 2006 Annual Social and Economic Supplements.

\section{Nativity}

The uninsured rate for the native population increased between 2004 and 2005, from 13.1 percent to 13.4 percent, while the uninsured rate for the foreign-born population was not statistically different at 33.6 percent in 2005 (Table 8). Among the foreign born, the number of uninsured naturalized citizens increased, from 2.3 million in 2004 to 2.5 million in 2005. The uninsured rate for naturalized citizens was not statistically different at 17.9 percent. For noncitizens, the number who were uninsured and the rate were statistically unchanged in 2005 at 9.5 million and 43.6 percent, respectively. The proportion of the foreign-born population without health insurance in 2005 was about two and a half times that of the native population in 2005.

\section{Economic Status}

The likelihood of being covered by health insurance rises with income. In 2005, in households with annual incomes of less than $\$ 25,000,75.6$ percent of people had health insurance. Health insurance coverage rates increased with higher household income levels to 91.5 percent for those in households with incomes of $\$ 75,000$ or more (Table 8 ).

The number of workers (people who worked at some time during the year) with no health insurance increased from 26.5 million to 27.3 million, while the percentage of workers who were uninsured was not statistically different at 18.7 percent. Among 18-to-64-year-olds in 2005, full-time workers were more likely to be covered by health insurance (82.3 percent) than part-time workers (76.5 percent) or nonworkers (72.7 percent). ${ }^{34}$ The number and the percentage of full-time workers who were uninsured increased from 20.5 million to 21.5 million and from 17.3 percent to 17.7 percent, respectively. The number and the percentage of part-time workers who were uninsured remained statistically unchanged in 2005 at 5.9 million and 23.5 percent, respectively.

${ }^{34}$ Workers are classified as part-time if they worked fewer than 35 hours per week in the majority of the weeks they worked in 2005. 


\section{Children's Health \\ Insurance Coverage}

The percentage and the number of children (people under 18 years old) without health insurance increased between 2004 and 2005, from

10.8 percent to 11.2 percent and from

7.9 million to 8.3 million, respectively

(Table 8). The likelihood of health

insurance coverage varied among

Figure 8.

Uninsured Children by Poverty Status, Age, and

Race and Hispanic Origin: 2005

(Percent)
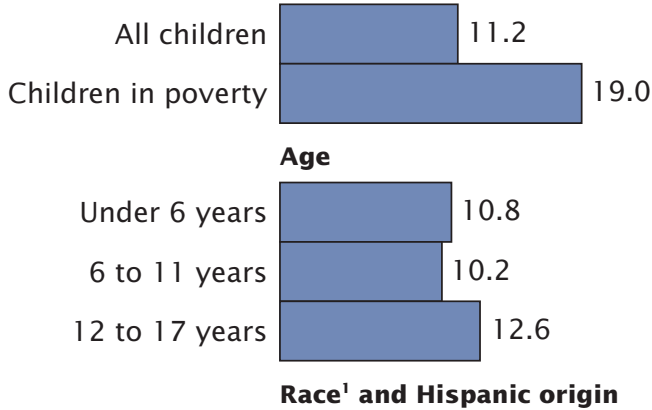

White, not Hispanic

Black

Asian

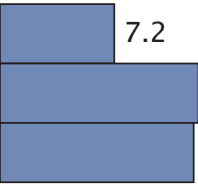

Hispanic origin (any race)
12.5

12.2
21.9

${ }^{1}$ Federal surveys now give respondents the option of reporting more than one race. Therefore, two basic ways of defining a race group are possible. A group such as Asian may be defined as those who reported Asian and no other race (the race-alone or single-race concept) or as those who reported Asian regardless of whether they also reported another race (the race-aloneor-in-combination concept). This figure shows data using the first approach (race alone). The use of the single-race population does not imply that it is the preferred method of presenting or analyzing data. The Census Bureau uses a variety of approaches. Information on people who reported more than one race, such as White and American Indian and Alaska Native or Asian and Black or African American, is available from Census 2000 through American FactFinder. About 2.6 percent of people reported more than one race in Census 2000.

Note: For discussion of statistically significant differences between groups, see text.

Source: U.S. Census Bureau, Current Population Survey, 2006 Annual Social and Economic Supplement.

children by poverty status, age, race, and Hispanic origin. Children in poverty were more likely to be uninsured than the population of all children in 2005-19.0 percent compared with 11.2 percent (Figure 8). ${ }^{35}$

Children 12 to 17 years old were more likely to be uninsured than those under 12 years old-12.6 percent compared with 10.5 percent. An estimated 21.9 percent of Hispanic children did not have any health insurance in 2005, compared with 7.2 percent for non-Hispanic White children, 12.5 percent for Black children, and 12.2 percent for Asian children. ${ }^{36}$ In 2005, the percentage of non-Hispanic White children covered by Medicaid was 18.0 percent; for Black children, 44.9 percent; for Asian children, 15.9 percent; and for Hispanic children, 39.3 percent. $^{37}$

${ }^{35}$ The uninsured rate for children under 6 years old was not statistically different from the uninsured rate for children 6 to 11 years old in 2005.

${ }^{36}$ The uninsured rates for Black children and Asian children were not statistically different from each other in 2005.

${ }^{37}$ The percentage of non-Hispanic White children covered by Medicaid was not statistically different from the percentage of Asian children covered by Medicaid. 


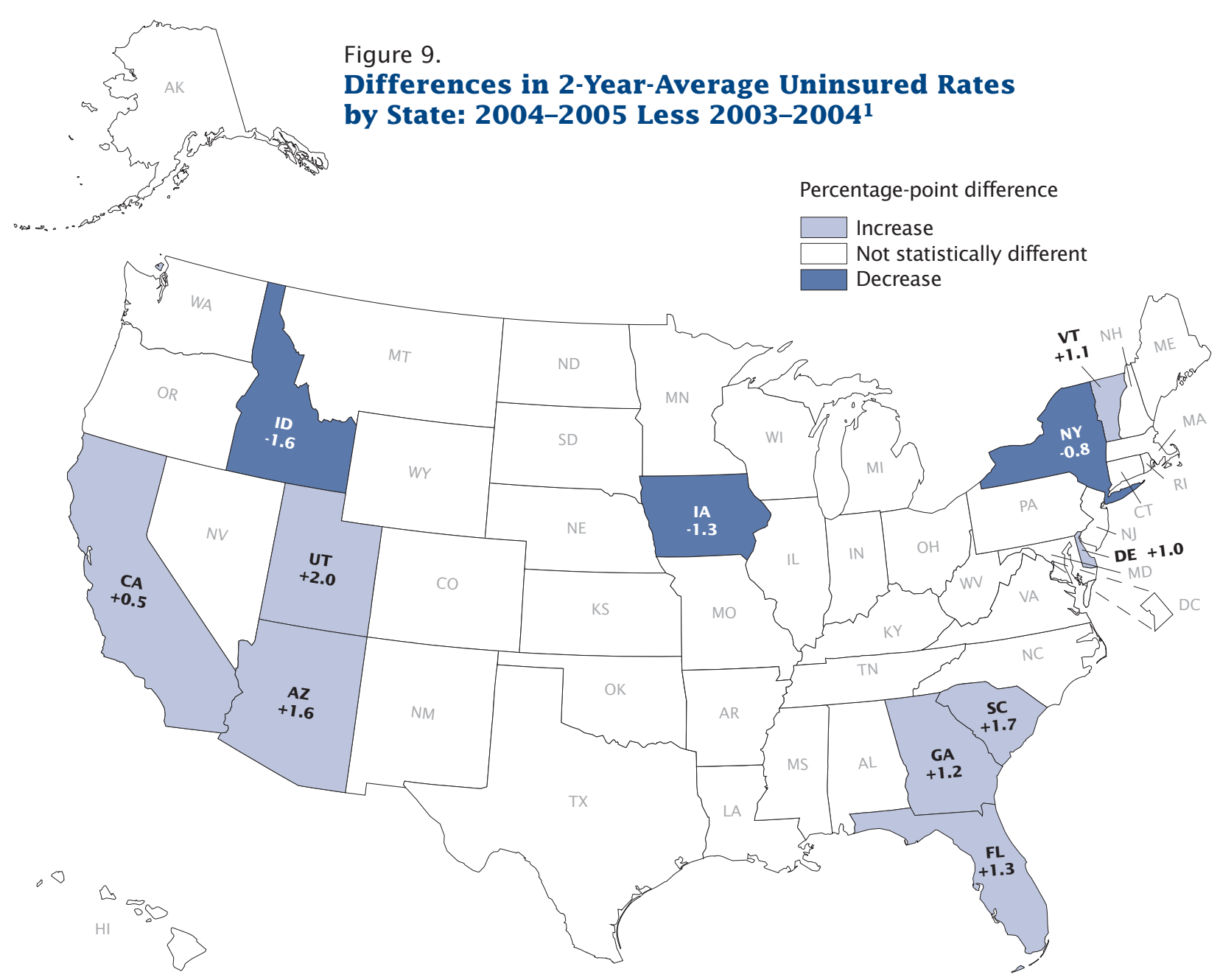

1 The 2004 data have been revised to reflect a correction to the weights in the 2005 ASEC. The estimates also reflect improvements to the algorithm that assigns coverage to dependents.

Source: U.S. Census Bureau, Current Population Survey, 2004 to 2006 Annual Social and Economic Supplements.

\section{Region}

The uninsured rate in the South increased from 18.2 percent to 18.6 percent between 2004 and 2005 . The West also experienced an increase in the percentage of uninsured, from 17.4 percent in 2004 to 18.1 percent in 2005..$^{38}$ The Midwest and the Northeast had the lowest uninsured rates in 2005, at 11.9 percent and 12.3 percent, respectively. ${ }^{39}$

${ }^{38}$ The uninsured rates for the South and the West were not statistically different from each other in 2005.

${ }^{39}$ The uninsured rates for the Midwest and the Northeast were not statistically different from each other in 2005.

\section{Residence}

In 2005, the uninsured rate was higher among people living within principal cities (18.7 percent) than among people living in the suburbs (14.1 percent). The percentage of the uninsured that lived outside metropolitan statistical areas was 15.6 percent in 2005.

\section{State Level Data}

Comparing across states using 3-yearaverage uninsured rates for 2003-2005 shows that Texas (24.6 percent) had the highest percentage of uninsured, while Minnesota
(8.7 percent) had the lowest uninsured rate. The rate for Minnesota was not statistically different from that of Hawaii (9.5 percent) (Table 10).

Comparisons of 2-year moving averages (2003-2004 and 2004-2005) show that the proportion of people without coverage fell in three states and rose in eight states (Figure 9). The uninsured rate decreased for Idaho, lowa, and New York. Four of the states that experienced increases were in the South (Delaware, Florida, Georgia, South Carolina), three were in the West (Arizona, California, Utah), and one was in the Northeast (Vermont). 
Table 10.

Percentage of People Without Health Insurance Coverage by State Using 2- and 3-Year Averages: 2003 to 2005

(People as of March of the following year)

\begin{tabular}{|c|c|c|c|c|c|c|c|c|}
\hline \multirow{3}{*}{ State } & \multirow{2}{*}{\multicolumn{2}{|c|}{$\begin{array}{l}\text { 3-year average } \\
2003-2005^{1}\end{array}$}} & \multicolumn{4}{|c|}{ 2-year average } & \multirow{2}{*}{\multicolumn{2}{|c|}{$\begin{array}{r}\text { Change in percentage points } \\
(2004-2005 \text { average less } \\
2003-2004 \text { average })^{2}\end{array}$}} \\
\hline & & & \multicolumn{2}{|c|}{$2003-2004^{1}$} & \multicolumn{2}{|c|}{$2004-2005^{1}$} & & \\
\hline & Percentage & $\begin{array}{r}\text { 90-percent } \\
\text { confidence } \\
\text { interval }^{3}( \pm)\end{array}$ & Percentage & $\begin{array}{r}\text { 90-percent } \\
\text { confidence } \\
\text { interval }^{3}( \pm)\end{array}$ & Percentage & $\begin{array}{r}\text { 90-percent } \\
\text { confidence } \\
\text { interval }^{3}( \pm)\end{array}$ & Percentage $^{4}$ & $\begin{array}{r}\text { 90-percent } \\
\text { confidence } \\
\text { interval }^{3}( \pm)\end{array}$ \\
\hline United States $\ldots \ldots \ldots \ldots \ldots \ldots$ & 15.7 & 0.1 & 15.6 & 0.1 & 15.7 & 0.1 & 0.1 & 0.1 \\
\hline Alabama . . . . . . . . . . . . & 14.3 & 1.0 & 13.8 & 1.1 & 14.4 & 1.2 & 0.6 & 1.0 \\
\hline Alaska $\ldots \ldots \ldots \ldots \ldots \ldots \ldots$ & 17.8 & 1.1 & 17.9 & 1.3 & 17.3 & 1.4 & -0.6 & 1.1 \\
\hline Arizona $\ldots \ldots \ldots \ldots \ldots \ldots \ldots$ & 18.1 & 1.0 & 17.1 & 1.2 & 18.7 & 1.2 & ${ }^{\star} 1.6$ & 1.1 \\
\hline Arkansas $\ldots \ldots \ldots \ldots \ldots \ldots \ldots \ldots$ & 17.2 & 1.1 & 16.9 & 1.3 & 17.1 & 1.3 & 0.2 & 1.1 \\
\hline California $\ldots \ldots \ldots \ldots \ldots \ldots \ldots$ & 18.8 & 0.4 & 18.5 & 0.5 & 19.0 & 0.5 & ${ }^{*} 0.5$ & 0.5 \\
\hline Colorado $\ldots \ldots \ldots \ldots \ldots \ldots \ldots \ldots$ & 16.9 & 1.0 & 16.9 & 1.2 & 16.8 & 1.3 & -0.1 & 1.0 \\
\hline Connecticut $\ldots \ldots \ldots \ldots \ldots \ldots \ldots$ & 11.0 & 0.9 & 10.8 & 1.0 & 11.3 & 1.1 & 0.4 & 0.8 \\
\hline Delaware $\ldots \ldots \ldots \ldots \ldots \ldots \ldots$ & 12.7 & 1.0 & 12.5 & 1.1 & 13.5 & 1.2 & *1.0 & 0.9 \\
\hline District of Columbia . . . . . . . . . . & 13.5 & 1.1 & 13.5 & 1.3 & 13.1 & 1.3 & -0.4 & 1.1 \\
\hline Florida $\ldots \ldots \ldots \ldots \ldots \ldots \ldots \ldots \ldots$ & 19.6 & 0.6 & 19.0 & 0.7 & 20.3 & 0.7 & *1.3 & 0.6 \\
\hline Georgia & 17.5 & 0.8 & 16.9 & 1.0 & 18.1 & 0.9 & *1.2 & 0.9 \\
\hline Hawaii $\ldots \ldots \ldots \ldots \ldots \ldots$ & 9.5 & 0.8 & 9.7 & 0.9 & 9.2 & 0.9 & -0.5 & 0.8 \\
\hline Idaho $\ldots \ldots \ldots \ldots \ldots \ldots \ldots \ldots \ldots$ & 16.5 & 1.1 & 17.1 & 1.3 & 15.5 & 1.2 & *-1.6 & 1.1 \\
\hline Illinois $\ldots \ldots \ldots \ldots \ldots \ldots \ldots \ldots \ldots \ldots \ldots \ldots \ldots$ & 14.2 & 0.6 & 14.2 & 0.7 & 14.2 & 0.7 & - & 0.6 \\
\hline Indiana $\ldots \ldots \ldots \ldots \ldots \ldots \ldots \ldots \ldots \ldots \ldots \ldots \ldots$ & 14.2 & 0.8 & 14.1 & 1.0 & 14.3 & 1.0 & 0.2 & 0.8 \\
\hline lowa $\ldots \ldots \ldots \ldots \ldots \ldots \ldots \ldots \ldots \ldots$ & 9.8 & 0.8 & 10.4 & 1.0 & 9.1 & 1.0 & *-1.3 & 0.8 \\
\hline 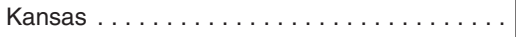 & 10.9 & 0.9 & 11.0 & 1.0 & 10.9 & 1.1 & -0.1 & 0.9 \\
\hline Kentucky $\ldots \ldots \ldots \ldots \ldots \ldots \ldots$ & 13.6 & 1.0 & 14.1 & 1.1 & 13.5 & 1.2 & -0.6 & 1.0 \\
\hline Louisiana . . . . . . . . . . . . . . & 18.7 & 1.1 & 18.7 & 1.3 & 17.7 & 1.3 & -0.9 & 1.2 \\
\hline Maine $\ldots \ldots \ldots \ldots \ldots \ldots \ldots$ & 10.4 & 0.9 & 10.2 & 1.0 & 10.5 & 1.1 & 0.2 & 0.9 \\
\hline Maryland $\ldots \ldots \ldots \ldots \ldots \ldots \ldots$ & 14.1 & 0.9 & 14.1 & 1.0 & 14.2 & 1.1 & 0.1 & 0.9 \\
\hline Massachusetts $\ldots \ldots \ldots \ldots \ldots \ldots$ & 10.7 & 0.7 & 11.2 & 0.8 & 10.7 & 0.9 & -0.5 & 0.7 \\
\hline Michigan . . . . . . . . . . . . . . & 11.3 & 0.6 & 11.3 & 0.7 & 11.5 & 0.7 & 0.2 & 0.6 \\
\hline Minnesota $\ldots \ldots \ldots \ldots \ldots \ldots \ldots$ & 8.7 & 0.7 & 8.8 & 0.8 & 8.7 & 0.9 & -0.2 & 0.7 \\
\hline Mississippi $\ldots \ldots \ldots \ldots \ldots \ldots \ldots \ldots$ & 17.3 & 1.1 & 17.3 & 1.3 & 17.1 & 1.3 & -0.3 & 1.1 \\
\hline Missouri $\ldots \ldots \ldots \ldots \ldots \ldots \ldots \ldots \ldots \ldots \ldots \ldots \ldots$ & 11.9 & 0.8 & 11.8 & 0.9 & 12.4 & 1.0 & 0.5 & 0.8 \\
\hline Montana . . . . . . . . . . . . . . & 18.7 & 1.1 & 19.3 & 1.4 & 18.4 & 1.4 & -1.0 & 1.2 \\
\hline Nebraska . . . . . . . . . . . . . . . & 11.4 & 0.9 & 11.2 & 1.0 & 11.4 & 1.1 & 0.2 & 0.9 \\
\hline Nevada $\ldots \ldots \ldots \ldots \ldots \ldots \ldots \ldots$ & 18.4 & 1.1 & 18.9 & 1.3 & 18.1 & 1.4 & -0.8 & 1.1 \\
\hline New Hampshire $\ldots \ldots \ldots \ldots \ldots \ldots \ldots$ & 10.4 & 0.9 & 10.5 & 1.0 & 10.5 & 1.1 & - & 0.8 \\
\hline New Jersey $\ldots \ldots \ldots \ldots \ldots \ldots \ldots \ldots$ & 14.5 & 0.7 & 14.2 & 0.8 & 14.8 & 0.9 & 0.6 & 0.7 \\
\hline New Mexico . . . . . . . . . . . . . . & 21.1 & 1.3 & 21.4 & 1.5 & 20.6 & 1.5 & -0.8 & 1.3 \\
\hline New York . . . . . . . . . . . . . . & 13.9 & 0.5 & 14.2 & 0.6 & 13.3 & 0.6 & *-0.8 & 0.5 \\
\hline North Carolina $\ldots \ldots \ldots \ldots \ldots \ldots \ldots$ & 16.2 & 0.8 & 16.3 & 0.9 & 15.6 & 0.9 & -0.6 & 0.8 \\
\hline North Dakota . . . . . . . . . . . . . . . . & 11.2 & 0.9 & 10.7 & 1.0 & 11.4 & 1.1 & 0.7 & 0.9 \\
\hline Ohio $\ldots \ldots \ldots \ldots \ldots \ldots \ldots \ldots \ldots \ldots \ldots \ldots \ldots \ldots$ & 12.0 & 0.6 & 11.8 & 0.7 & 11.9 & 0.7 & 0.1 & 0.6 \\
\hline Oklahoma ................... & 19.5 & 1.1 & 20.0 & 1.3 & 19.0 & 1.4 & -1.0 & 1.1 \\
\hline Oregon $\ldots \ldots \ldots \ldots \ldots \ldots \ldots \ldots$ & 16.7 & 1.1 & 17.0 & 1.2 & 16.4 & 1.3 & -0.6 & 1.1 \\
\hline Pennsylvania $\ldots \ldots \ldots \ldots \ldots \ldots \ldots$ & 11.2 & 0.5 & 11.6 & 0.6 & 11.1 & 0.6 & -0.5 & 0.5 \\
\hline Rhode Island $\ldots \ldots \ldots \ldots \ldots \ldots \ldots$ & 11.0 & 0.9 & 10.5 & 1.0 & 11.4 & 1.2 & 0.8 & 0.9 \\
\hline South Carolina . . . . . . . . . . . . & 15.6 & 1.0 & 14.6 & 1.1 & 16.3 & 1.3 & *1.7 & 1.0 \\
\hline South Dakota . . . . . . . . . . . . . . & 12.1 & 0.9 & 12.0 & 1.0 & 12.1 & 1.1 & 0.1 & 0.9 \\
\hline Tennessee $\ldots \ldots \ldots \ldots \ldots \ldots \ldots \ldots$ & 13.7 & 0.9 & 13.5 & 1.0 & 14.0 & 1.0 & 0.5 & 0.9 \\
\hline Texas $\ldots \ldots \ldots \ldots \ldots \ldots \ldots \ldots \ldots \ldots$ & 24.6 & 0.6 & 24.7 & 0.7 & 24.5 & 0.7 & -0.2 & 0.6 \\
\hline 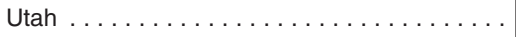 & 14.5 & 0.9 & 13.5 & 1.1 & 15.5 & 1.2 & *2.0 & 1.0 \\
\hline Vermont $\ldots \ldots \ldots \ldots \ldots \ldots \ldots$ & 10.7 & 0.9 & 10.3 & 1.0 & 11.4 & 1.2 & *1.1 & 0.9 \\
\hline Virginia . . . . . . . . . . . . & 13.6 & 0.8 & 13.6 & 0.9 & 13.9 & 0.9 & 0.3 & 0.8 \\
\hline Washington $\ldots \ldots \ldots \ldots \ldots \ldots \ldots$ & 14.1 & 0.9 & 14.3 & 1.0 & 13.4 & 1.0 & -0.8 & 0.9 \\
\hline West Virginia $\ldots \ldots \ldots \ldots \ldots \ldots \ldots$ & 16.9 & 1.0 & 16.4 & 1.1 & 17.0 & 1.2 & 0.6 & 1.0 \\
\hline Wisconsin ..... & 10.3 & 0.8 & 10.6 & 0.9 & 10.0 & 0.9 & -0.6 & 0.8 \\
\hline Wyoming $\ldots \ldots \ldots$ & 15.2 & 1.1 & 14.7 & 1.2 & 14.8 & 1.3 & 0.1 & 1.1 \\
\hline
\end{tabular}

- Represents zero or rounds to zero.

* Statistically different from zero at the 90 -percent confidence level.

${ }^{1}$ The 2004 data have been revised to reflect a correction to the weights in the 2005 ASEC. The estimates also reflect improvements to the algorithm that assigns coverage to dependents.

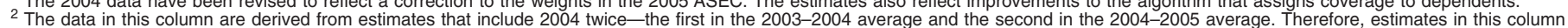
are equivalent to measuring half of the percentage-point difference between 2003 and 2005

A 90-percent confidence interval is a measure of an estimate's variability. The larger the confidence interval in relation to the size of the estimate, the less reliable the estimate. For more formation, see "Standard Errors and Their Use" at <www.census.gov/hhes/www/p60_231sa.pdf>.

Details may not sum to totals because of rounding.

Source: U.S. Census Bureau, Current Population Survey, 2004 to 2006 Annual Social and Economic Supplements. 


\section{Additional Data and Contacts}

Detailed tables, historical tables, press releases and briefings, and unpublished data are available electronically on the Census Bureau's Income, Poverty, and Health Insurance Web sites. The Web sites may be accessed through the Census Bureau's home page at $\langle w w w$.census.gov $\rangle$ or directly at $<$ www.census.gov/hhes/www/income/income.html $>$ for income data, $<$ www.census.gov/hhes/www/poverty/poverty.html $>$ for poverty data, and $<$ www.census.gov/hhes/www/hlthins/hlthins.html $>$ for health insurance data. Microdata are available for downloading by clicking on "Data Tools" on the Census Bureau's home page and then clicking the "DataFerrett" link. Technical methods have been applied to CPS microdata to avoid disclosing the identities of individuals from whom data were collected.

For assistance with income, poverty, or health insurance data or questions about them, contact the Housing and Household Economic Statistics Division statistical information staff by telephone at 301-763-3242 or search your topic of interest using the Census Bureau's "Question and Answer Center" found at <http://ask.census.gov $>$.

\section{CPS DATA COLLECTION}

The information in this report was collected in the 50 states and the District of Columbia and does not represent residents of Puerto Rico and U.S. island areas. ${ }^{40}$ It is based on a sample of about 100,000 addresses. The estimates in this report are controlled to national population estimates by age, race, sex, and Hispanic origin, and to state population estimates by age.

${ }^{40}$ U.S. island areas include American Samoa, Guam, the Northern Mariana Islands, and the Virgin Islands of the United States.
The population controls used to prepare estimates for 1999 to 2004 were based on the results from Census 2000 and are updated annually using administrative records such as birth and death certificates.

The CPS is a household survey primarily used to collect employment data. The sample universe for the basic CPS consists of the resident civilian noninstitutionalized population of the United States. People in institutions, such as prisons, longterm care hospitals, and nursing homes, are therefore not eligible to be interviewed in the CPS. Students living in dormitories are only included in the estimates if information about them is reported in an interview at their parents' homes. The sample universe for the CPS ASEC is slightly larger than the basic CPS since it includes military personnel who live in a household with at least one other civilian adult, regardless of whether they live off post or on post. All other Armed Forces are excluded. For further documentation about the CPS ASEC, see <www.bls.census.gov /cps/ads/adsmain.htm>.

\section{COMMENTS}

The Census Bureau welcomes the comments and advice of data and report users. If you have suggestions or comments, please write to:

Charles Nelson

Assistant Division Chief for Income, Poverty, and Health Statistics Housing and Household Economic Statistics Division

U.S. Census Bureau

Washington, DC 20233-8500

or send e-mail to <charles.t.nelson@census.gov>. 


\section{APPENDIX A. ESTIMATES OF INCOME}

\section{How Income Is Measured}

For each person in the sample 15 years and over, the Annual Social and Economic Supplement (ASEC) asks questions on the amount of money income received in the preceding calendar year from each of the following sources:

1. Earnings

2. Unemployment compensation

3. Workers' compensation

4. Social security

5. Supplemental security income

6. Public assistance

7. Veterans' payments

8. Survivor benefits

9. Disability benefits

10. Pension or retirement income

11. Interest

12. Dividends

13. Rents, royalties, and estates and trusts

14. Educational assistance

15. Alimony

16. Child support

17. Financial assistance from outside of the household

18. Other income

It should be noted that although the income statistics refer to receipts during the preceding calendar year, the demographic characteristics, such as age, labor force status, and household composition, are as of the survey date. The income of the household does not include amounts received by people who were members during all or part of the previous year if these people no longer resided in the household at the time of interview. The Current Population Survey (CPS) collects income data for people who are current residents but did not

\begin{tabular}{|llll|}
\hline Recessions & & & \\
Peak month & Year & Trough month & Year \\
\hline November & 1948 & October & 1949 \\
July & 1953 & May & 1954 \\
August & 1957 & April & 1958 \\
April & 1960 & February & 1961 \\
December & 1969 & November & 1970 \\
November & 1973 & March & 1975 \\
January & 1980 & July & 1980 \\
July & 1981 & November & 1982 \\
July & 1990 & March & 1991 \\
March & 2001 & November & 2001 \\
\hline Source: National Bureau of Economic Research, Inc. & & \\
\multicolumn{1}{r}{ 1050 Massachusetts Avenue } & & \\
\hline
\end{tabular}

reside in the household during the previous year.

Data on income collected in the ASEC by the U.S. Census Bureau cover money income received (exclusive of certain money receipts such as capital gains) before payments for personal income taxes, social security, union dues, Medicare deductions, etc. Therefore, money income does not reflect the fact that some families receive noncash benefits, such as food stamps, health benefits, subsidized housing, and goods produced and consumed on the farm. In addition, money income does not reflect the fact that noncash benefits are also received by some nonfarm residents, which often take the form of the use of business transportation and facilities, full or partial payments by business for retirement programs, medical and educational expenses, etc. Data users should consider these elements when comparing income levels. Moreover, readers should be aware that for many different reasons there is a tendency in household surveys for respondents to underreport their income. Based on an analysis of independently derived income estimates, the Census Bureau determined that respondents report income earned from wages or salaries much better than other sources of income, and that the reported wage and salary income is nearly equal to independent estimates of aggregate income.

\section{Cost of Living Adjustment}

In order to accurately assess changes in income and earnings over time, an adjustment for changes in the cost of living is required. The Census Bureau uses the research series of the Consumer Price Index (CPI-U-RS), provided by the Bureau of Labor Statistics for 1967 through 2005, to adjust for changes in the cost of living. The indexes used to make the constant dollar conversions are shown on page 30 . 


\section{Annual Average Consumer Price Index Research Series Using Current Methods (CPI-U-RS) All Items: 1947 to 2005}

\begin{tabular}{|c|c|c|c|}
\hline Year & CPI-U-RS ${ }^{1}$ & Year & CPI-U-RS ${ }^{1}$ \\
\hline 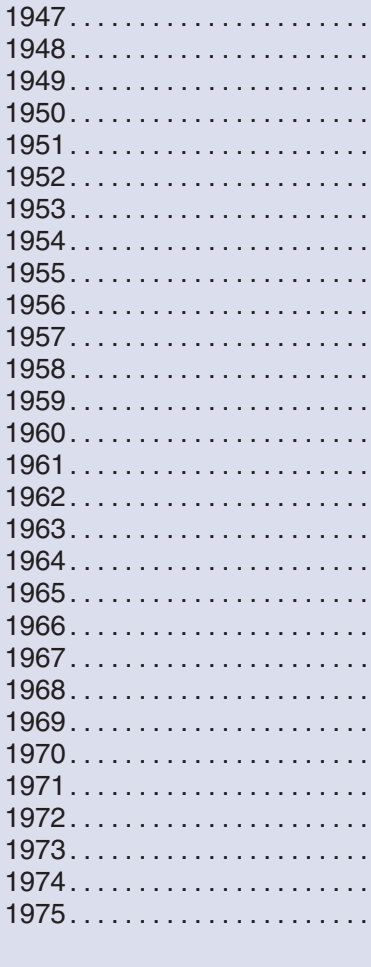 & $\begin{array}{l}38.3 \\
41.4 \\
40.9 \\
41.4 \\
44.7 \\
45.6 \\
45.9 \\
46.3 \\
46.1 \\
46.8 \\
48.3 \\
49.7 \\
50.0 \\
50.9 \\
51.4 \\
51.9 \\
52.6 \\
53.3 \\
54.2 \\
55.7 \\
57.4 \\
59.7 \\
62.3 \\
65.3 \\
68.2 \\
70.3 \\
74.7 \\
82.1 \\
88.9\end{array}$ & 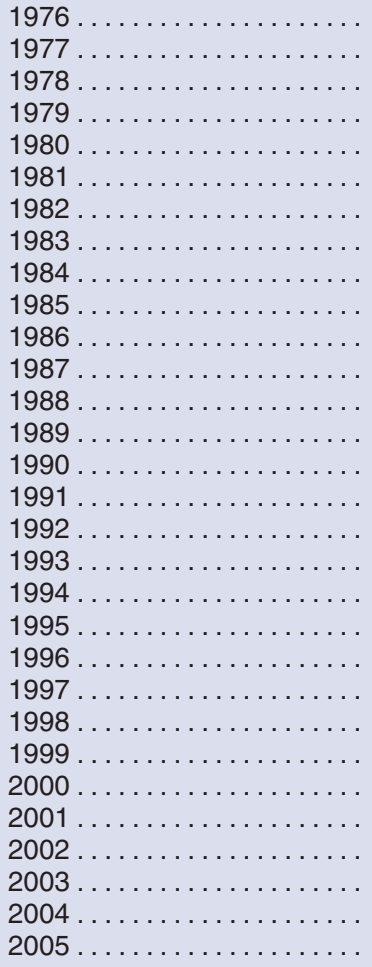 & $\begin{array}{r}94.0 \\
100.0 \\
104.3 \\
114.1 \\
126.7 \\
138.6 \\
146.8 \\
152.9 \\
159.0 \\
164.3 \\
167.3 \\
173.0 \\
179.3 \\
187.0 \\
196.3 \\
203.4 \\
208.5 \\
213.7 \\
218.2 \\
223.5 \\
229.5 \\
234.4 \\
237.7 \\
242.7 \\
250.8 \\
257.8 \\
261.9 \\
267.9 \\
275.1 \\
284.3\end{array}$ \\
\hline
\end{tabular}

1 The Census Bureau uses the Bureau of Labor Statistics' experimental Consumer Price Index (CPI-U-RS) for 1977 through 2005. The Census Bureau derived the CPI-U-RS for years before 1977 by applying the $1977 \mathrm{CPI}-\mathrm{U}-\mathrm{RS}$-to-CPI-U ratio to the 1947 to $1976 \mathrm{CPI}-\mathrm{U}$.

Note: Data users can compute the percentage changes in prices between earlier years' data and 2005 data by dividing the annual average Consumer Price Index (CPI-U-RS) for 2005 by the annual average for the earlier year(s).

For more information on the CPI-U-RS, go to <www.bls.gov/cpi/cpirsdc.htm>. 


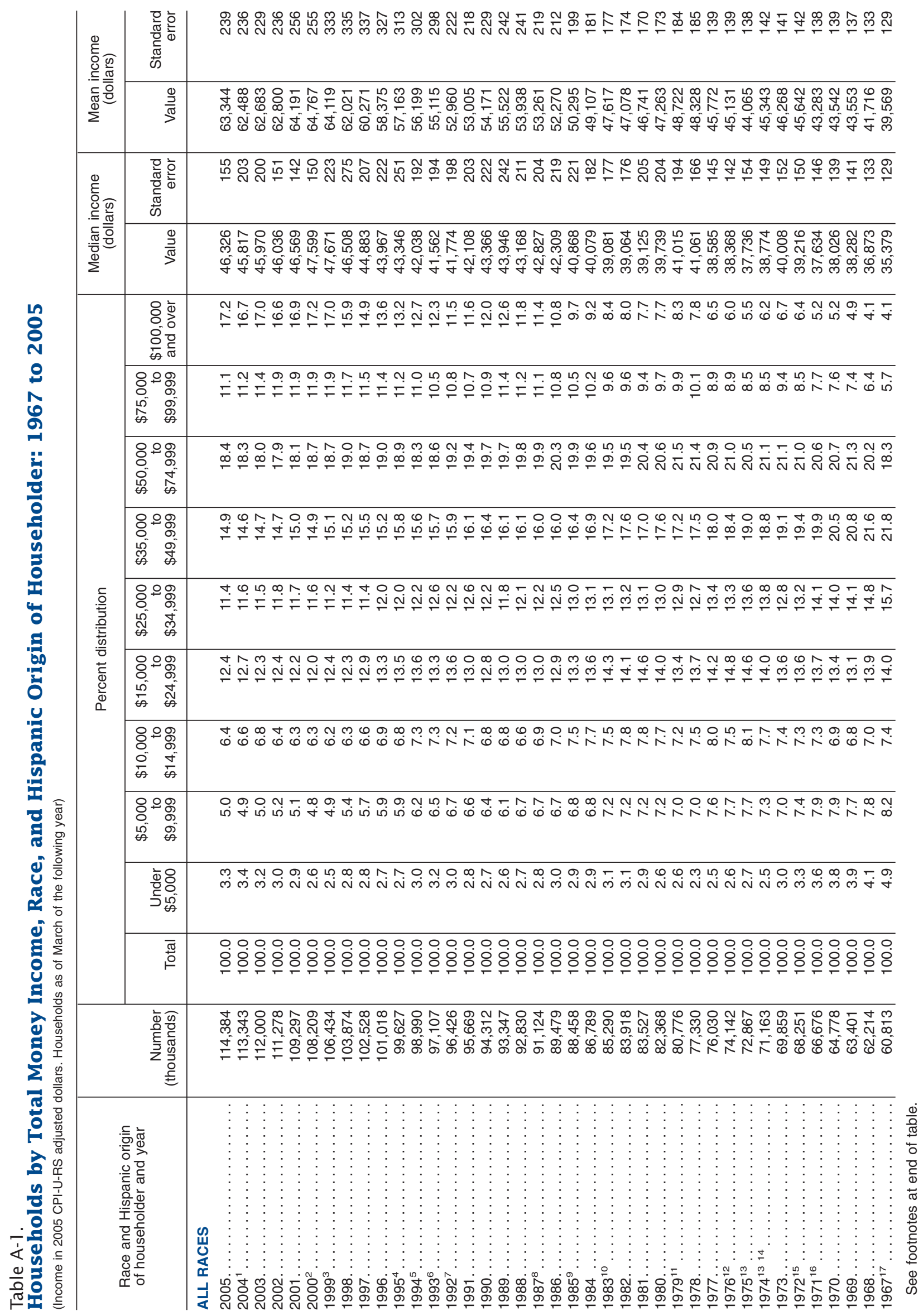




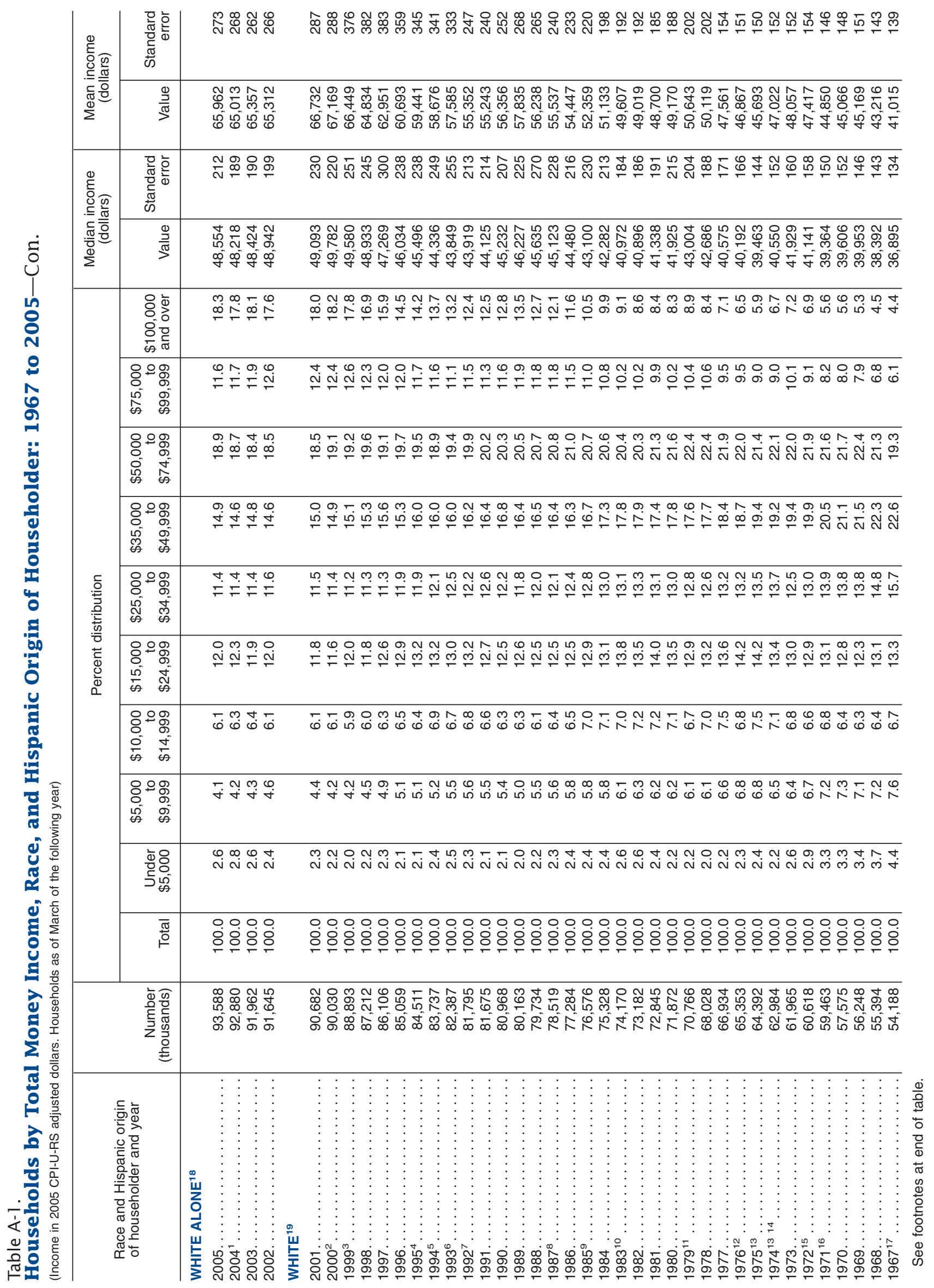




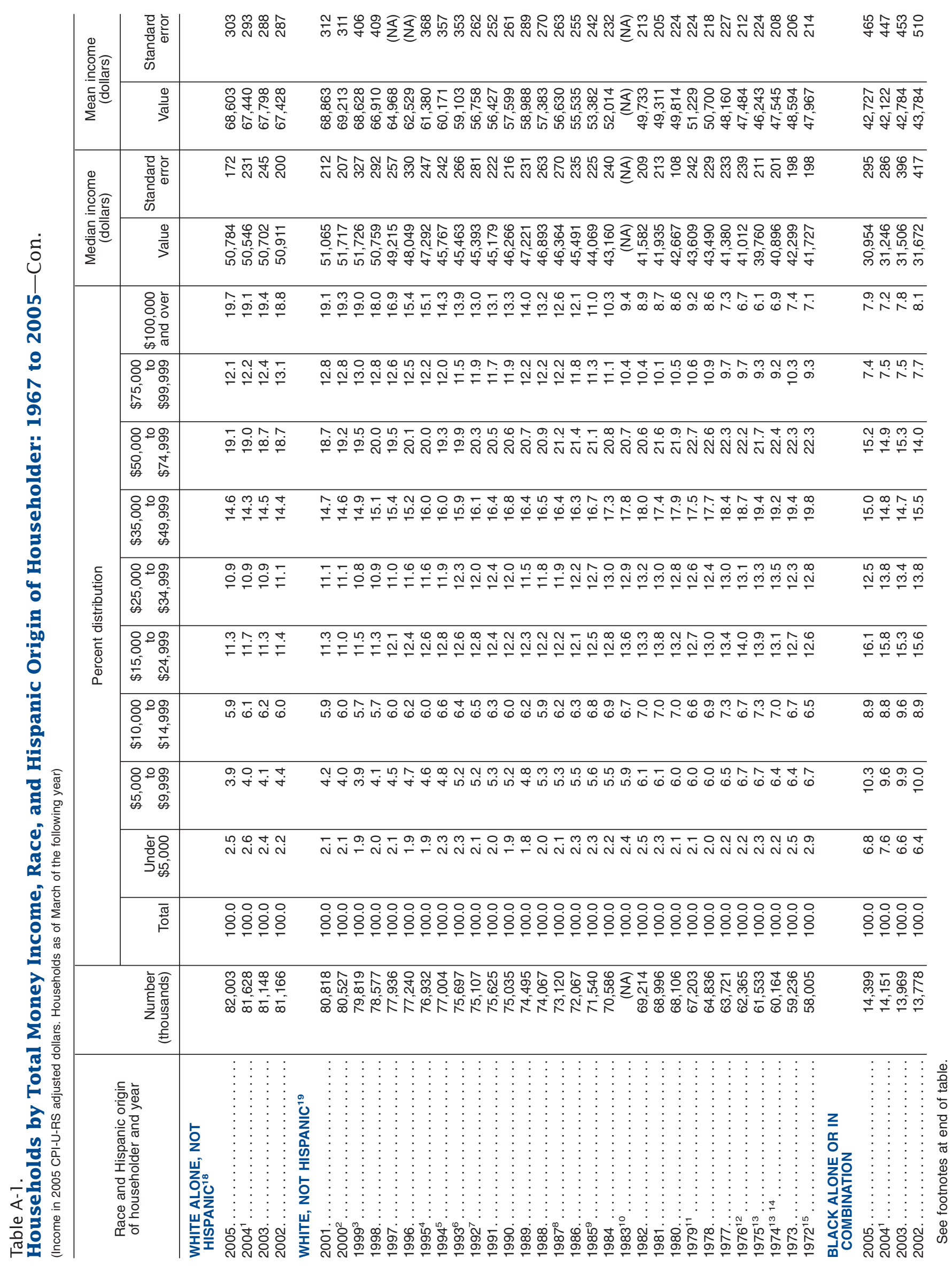




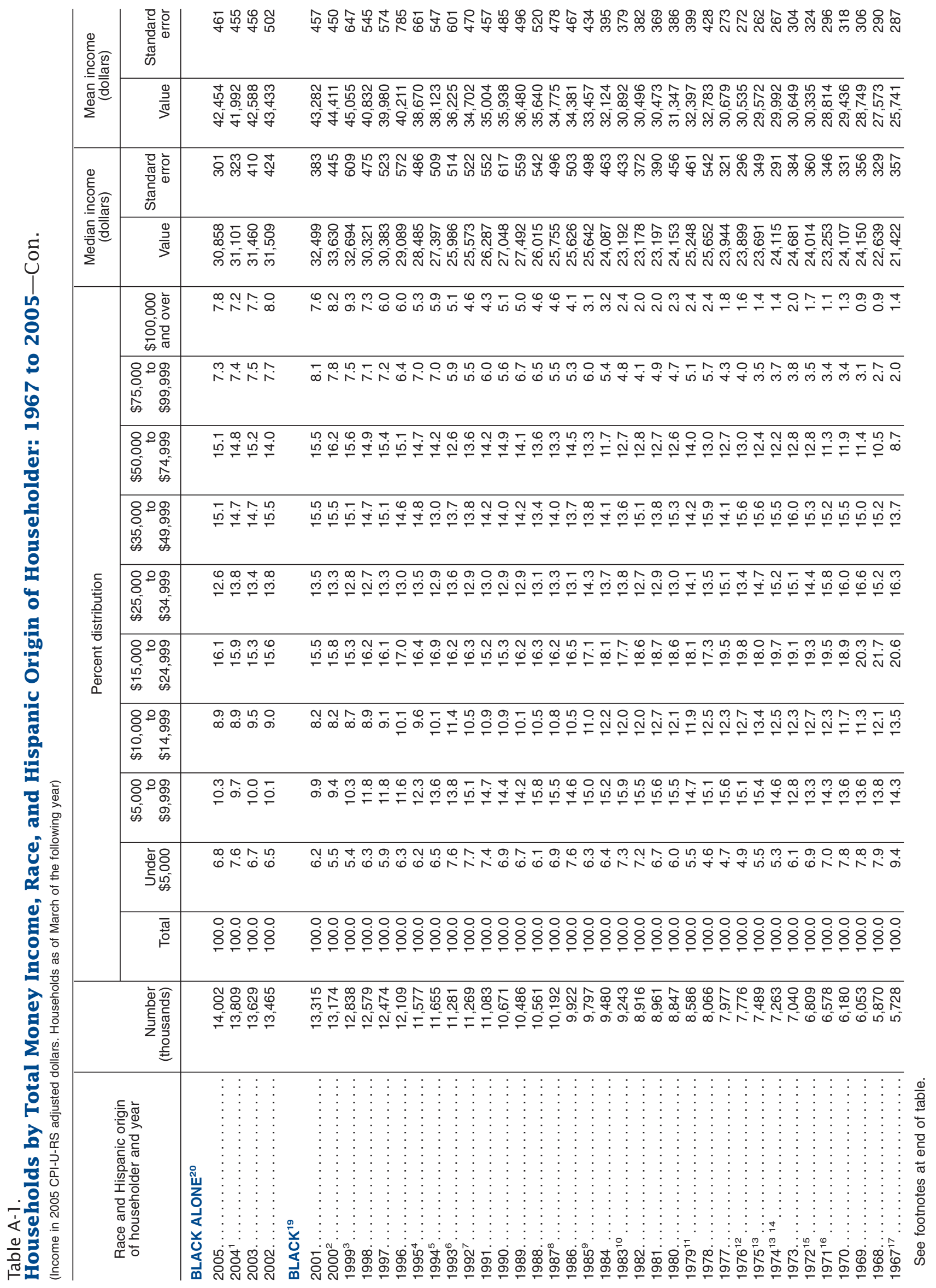




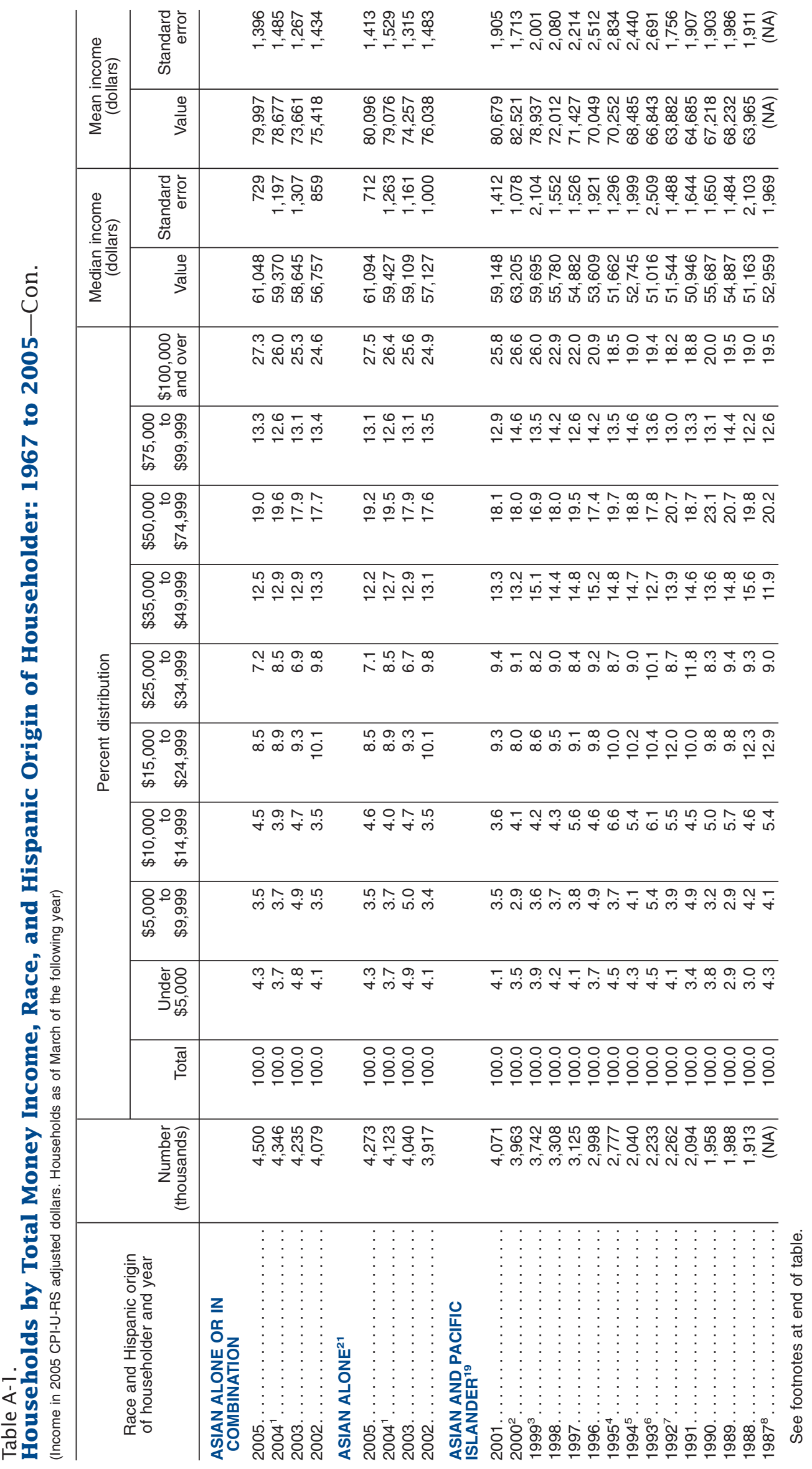




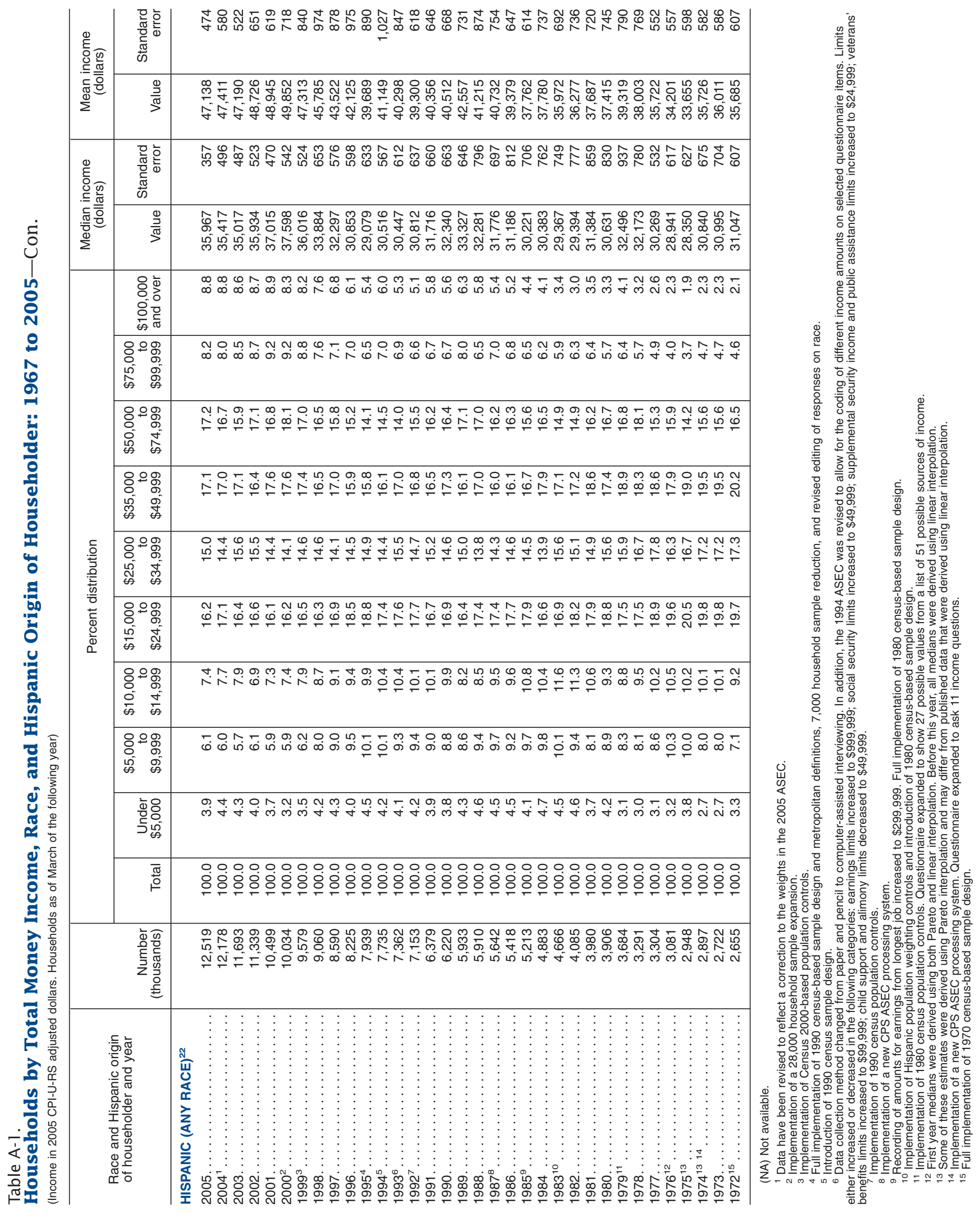




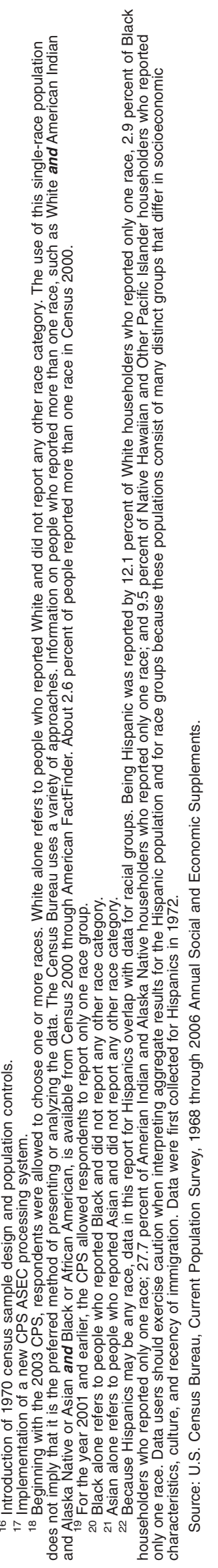

U.S. Census Bureau

Income, Poverty, and Health Insurance Coverage in the United States: 200537 
Table A-2. Real Median Earnings of Full-Time, Year-Round Workers by Sex and Female-to-Male Earnings
Ratio: 1960 to 2005

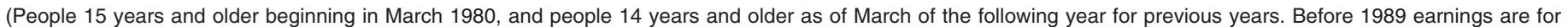
civilian workers only. Earnings in $2005 \mathrm{CPI}-\mathrm{U}-\mathrm{RS}$ adjusted dollars)

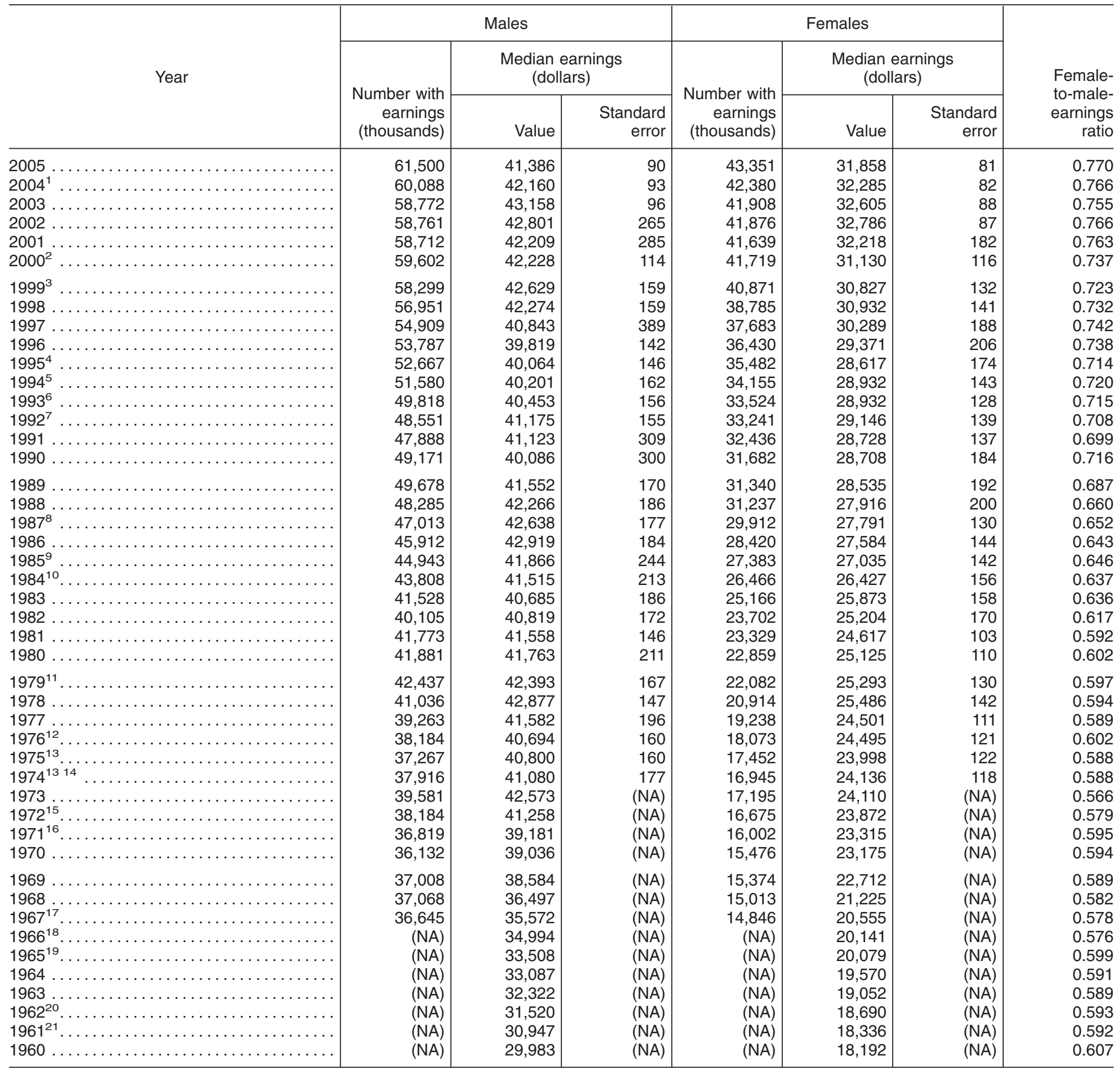

(NA) Not available.

1 The 2004 data have been revised to reflect a correction to the weights in the 2005 ASEC.

2 Implementation of a 28,000 household sample expansion.

${ }^{3}$ Implementation of Census 2000-based population controls.

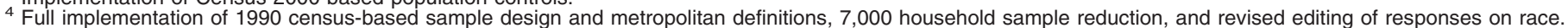

5 Introduction of 1990 census sample design.

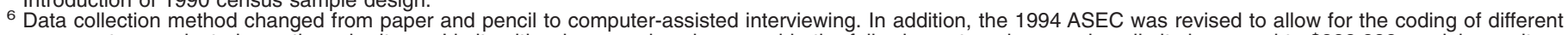

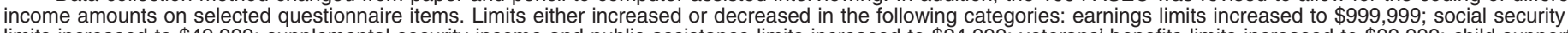

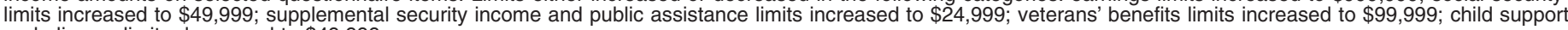
and alimony limits decreased to $\$ 49,999$.

7 Implementation of 1990 census population controls. 
8 Implementation of a new CPS ASEC processing system.

${ }_{9}^{9}$ Recording of amounts for earnings from longest job increased to $\$ 299,999$. Full implementation of 1980 census-based sample design.

${ }^{10}$ Implementation of Hispanic population weighting controls and introduction of 1980 census-based sample design.

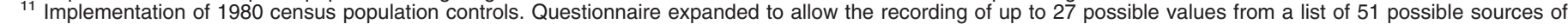
income.

12 First year medians were derived using both Pareto and linear interpolation. Before this year, all medians were derived using linear interpolation.

13 Some of these estimates were derived using Pareto interpolation and may differ from published data that were derived using linear interpolation.

${ }_{14}$ Implementation of a new CPS ASEC processing system. Questionnaire expanded to ask 11 income questions.

15 Full implementation of 1970 census-based sample design.

16 Introduction of 1970 census sample design and population controls.

17 Implementation of a new CPS ASEC processing system.

18 Questionnaire expanded to ask eight income questions.

19 Implementation of new procedures to impute missing data only.

20 Full implementation of 1960 census-based sample design and population controls.

21 Introduction of 1960 census-based sample design. Implementation of first hotdeck procedure to impute missing income entries.

Source: U.S. Census Bureau, Current Population Survey, 1961 through 2006 Annual Social and Economic Supplements. 


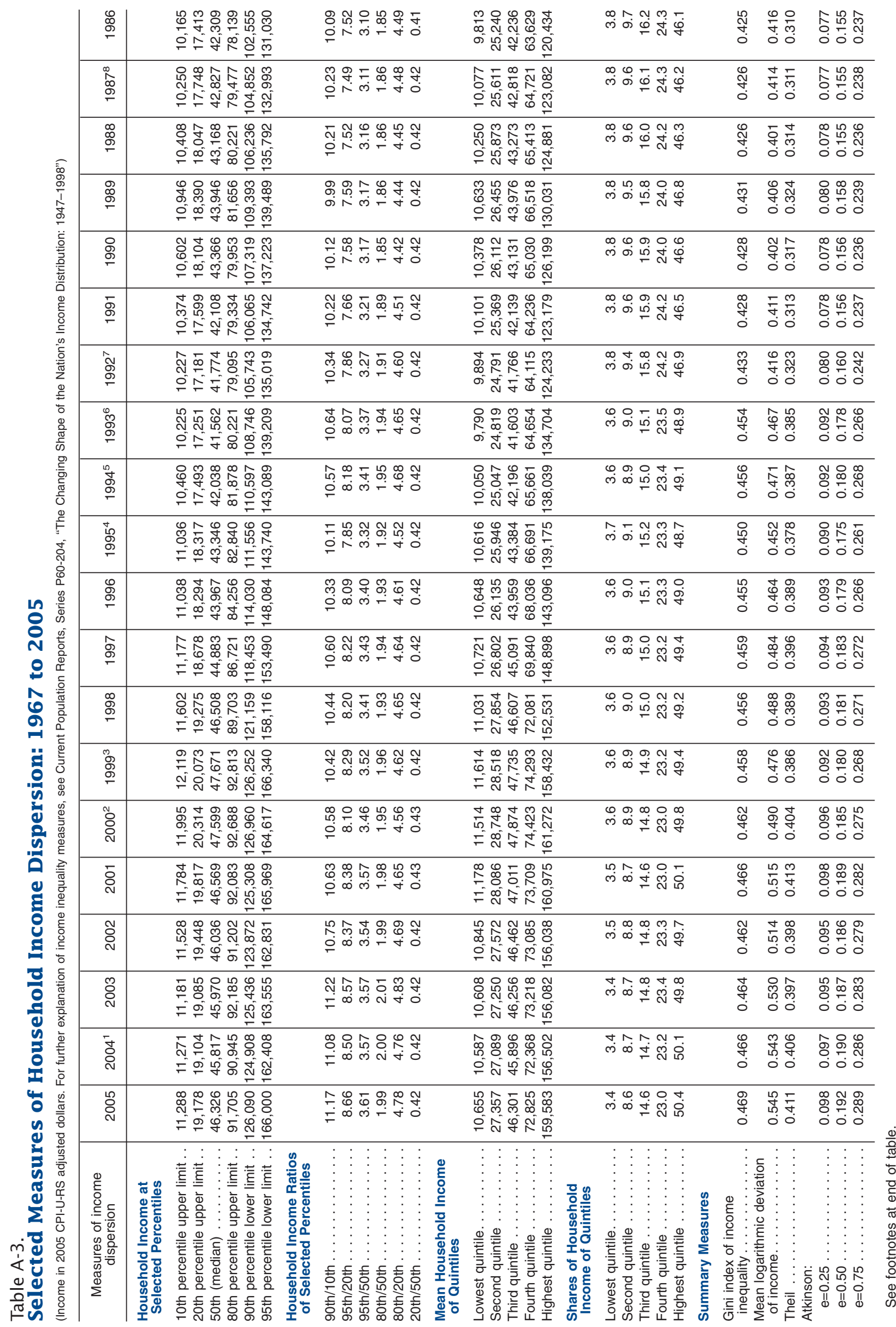




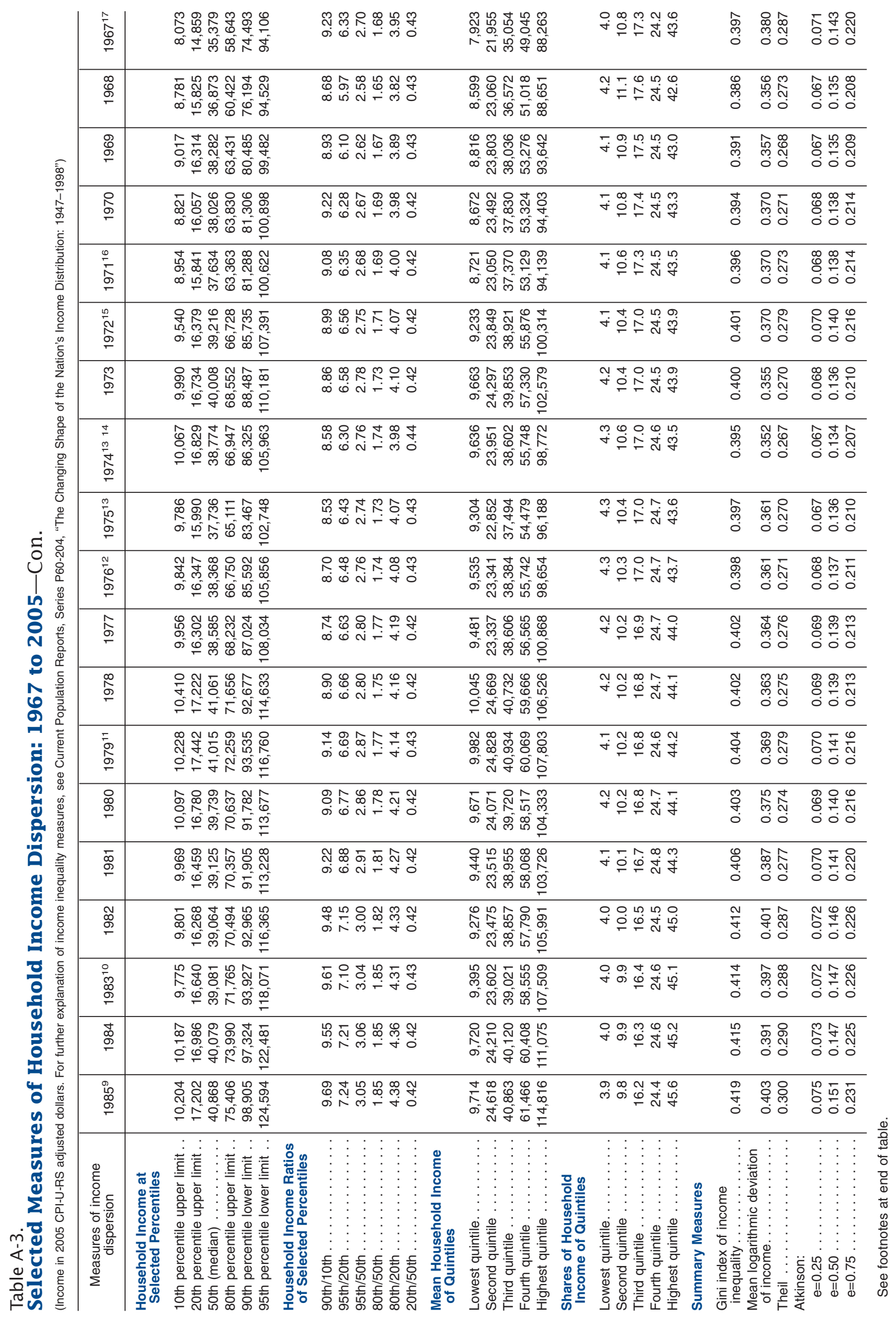




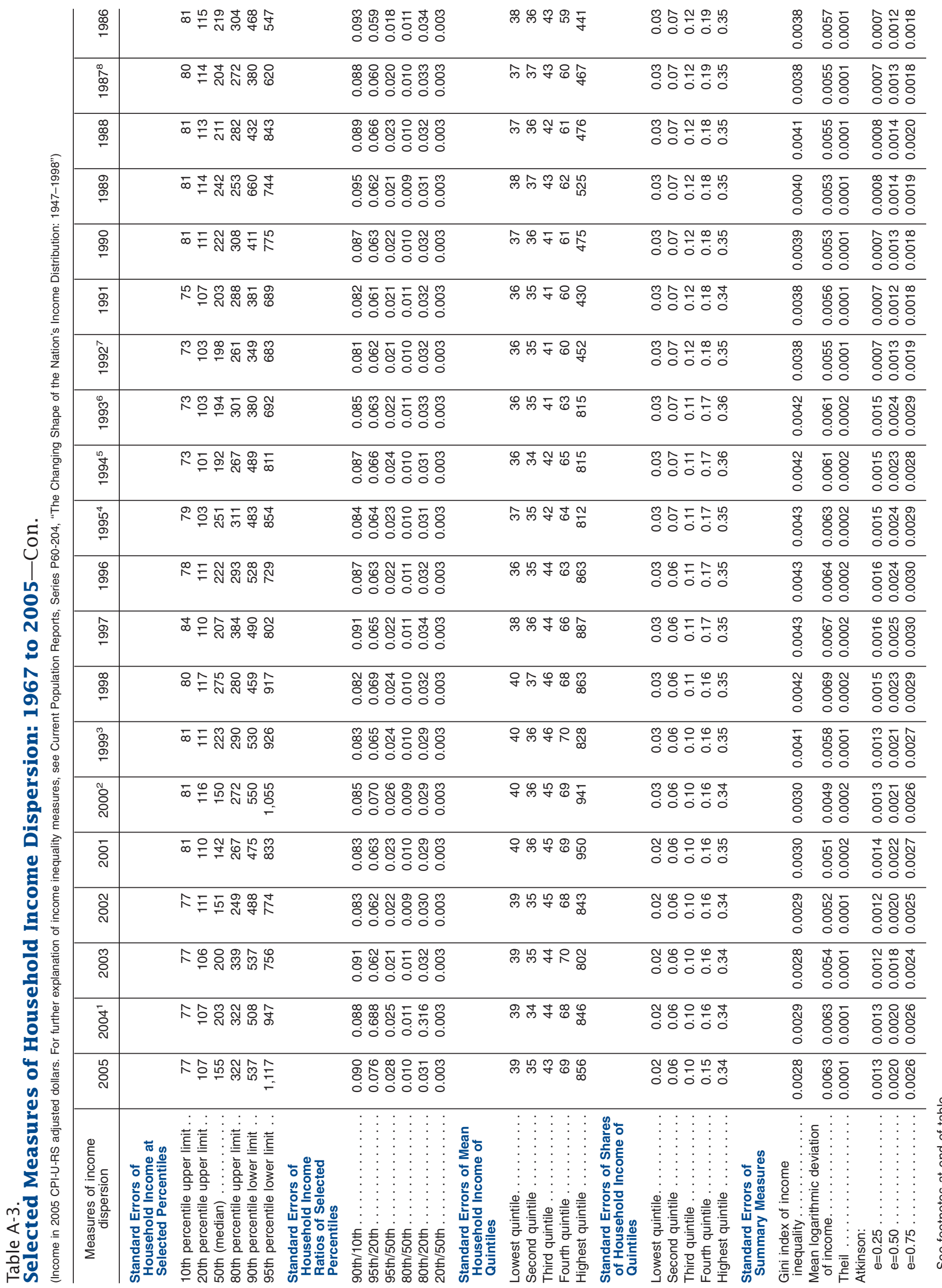




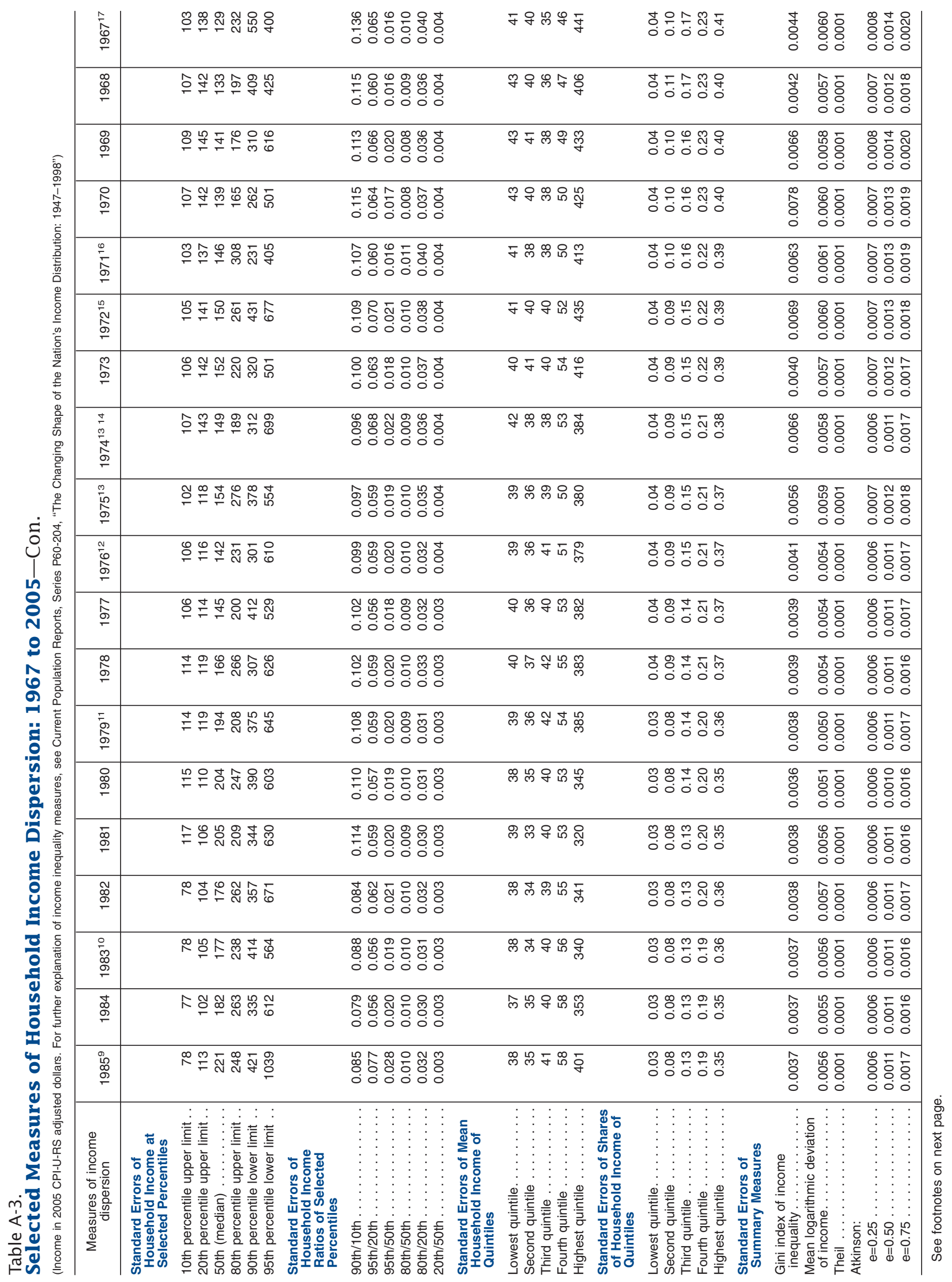




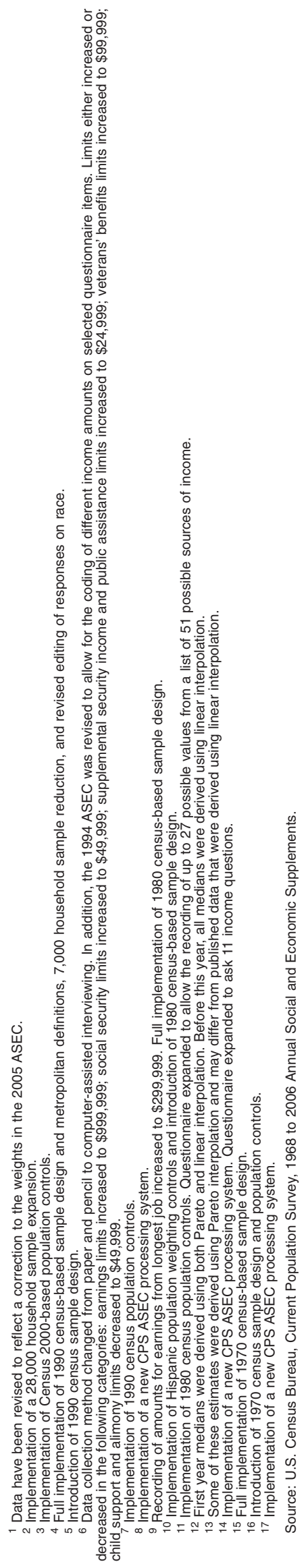

44 Income, Poverty, and Health Insurance Coverage in the United States: 2005

U.S. Census Bureau 


\section{APPENDIX B. \\ ESTIMATES OF POVERTY}

\section{How Poverty Is Calculated}

Following the Office of Management and Budget's (OMB) Statistical Policy Directive 14, the U.S. Census Bureau uses a set of money income thresholds that vary by family size and composition to determine who is in poverty (see the matrix below).

\section{Poverty Thresholds in 2005 by Size of Family and Number of Related Children Under 18 Years}

(Dollars)

\begin{tabular}{|c|c|c|c|c|c|c|c|c|c|}
\hline \multirow{2}{*}{ Size of family unit } & \multicolumn{9}{|c|}{ Related children under 18 years } \\
\hline & None & One & Two & Three & Four & Five & Six & Seven & $\begin{array}{l}\text { Eight or } \\
\text { more }\end{array}$ \\
\hline $\begin{array}{l}\text { One person (unrelated individual): } \\
\text { Under } 65 \text { years. } \ldots \ldots \ldots \ldots \ldots \ldots \ldots \\
65 \text { years and older. } \ldots \ldots \ldots \ldots \ldots\end{array}$ & $\begin{array}{r}10,160 \\
9,367\end{array}$ & & & & & & & & \\
\hline $\begin{array}{l}\text { Two people: } \\
\text { Householder under } 65 \text { years...... } \\
\text { Householder } 65 \text { years and older... }\end{array}$ & $\begin{array}{l}13,078 \\
11,805\end{array}$ & $\begin{array}{l}13,461 \\
13,410\end{array}$ & & & & & & & \\
\hline Three people ...... & 15,277 & 15,720 & 15,735 & & & & & & \\
\hline Four people........... & 20,144 & 20,474 & 19,806 & 19,874 & & & & & \\
\hline Five people $\ldots . . \ldots$ & 24,293 & 24,646 & 23,891 & 23,307 & 22,951 & & & & \\
\hline Six people...... & 27,941 & 28,052 & 27,474 & 26,920 & 26,096 & 25,608 & & & \\
\hline Seven people & 32,150 & 32,350 & 31,658 & 31,176 & 30,277 & 29,229 & 28,079 & & \\
\hline Eight people . & 35,957 & 36,274 & 35,621 & 35,049 & 34,237 & 33,207 & 32,135 & 31,862 & \\
\hline Nine people or more & 43,254 & 43,463 & 42,885 & 42,400 & 41,603 & 40,507 & 39,515 & 39,270 & 37,757 \\
\hline
\end{tabular}

Source: U.S. Census Bureau.

If a family's total income is less than that family's threshold, then that family and every individual in it is considered in poverty. The official poverty thresholds do not vary geographically, but they are updated annually for inflation using the Consumer Price Index (CPI-U). The official poverty definition uses money income before taxes and does not include capital gains or noncash benefits (such as public housing, Medicaid, and food stamps).

Example: Suppose Family A consists of five people: two children, their mother, their father, and their greataunt. Family A's poverty threshold in 2005 was $\$ 23,891$. Suppose also that each member had the following income in 2005:

$\begin{array}{lr}\text { Mother } & \$ 10,000 \\ \text { Father } & 5,000 \\ \text { Great-aunt } & 10,000 \\ \text { First child } & 0 \\ \text { Second child } & 0 \\ \quad \text { Total: } & \$ 25,000\end{array}$

Total:

$\$ 25,000$
Since their total family income, $\$ 25,000$, was greater than their threshold $(\$ 23,891)$, the family would not be considered "in poverty" according to the official poverty measure.

While the thresholds in some sense represent families' needs, they should be interpreted as a statistical yardstick rather than as a complete description of what people and families need to live. Many of the government's aid programs use different dollar amounts as eligibility criteria.

Poverty rates and the number in poverty are important ways of examining people's well-being. Other more detailed measures of poverty are considered in the section "Depth of Poverty Measures," and in the recent Census Bureau report Supplemental Measures of Material Well-Being: Expenditures, Consumption, and Poverty (P23-201).

For a history of the official poverty measure, see "The Development of the Orshansky Poverty Thresholds and
Their Subsequent History as the Official U.S. Poverty Measure" by Gordon M. Fisher, available at <www.census.gov/hhes/www/poverty /histofpovmeas.html>.

Weighted average thresholds: Some data users want a summary of the 48 thresholds to get a general sense of the "poverty line." The average thresholds shown below provide that summary, but they are not used to compute poverty data. The averages are based on the relative number of families by size and composition.

\section{Weighted Average Poverty Thresholds in 2005 by Size of Family}

(Dollars)

\begin{tabular}{lr}
\hline One person & 9,973 \\
Two people & 12,755 \\
Three people & 15,577 \\
Four people & 19,971 \\
Five people & 23,613 \\
Six people & 26,683 \\
Seven people & 30,249 \\
Eight people & 33,610 \\
Nine people or more & 40,288 \\
\hline \multicolumn{2}{c}{ Source: U.S. Census Bureau. }
\end{tabular}


Table B-1.

Poverty Status of People by Family Relationship, Race, and Hispanic Origin: 1959 to 2005

(Numbers in thousands. People as of March of the following year)

\begin{tabular}{|c|c|c|c|c|c|c|c|c|c|c|c|c|}
\hline \multirow{4}{*}{$\begin{array}{l}\text { Race, Hispanic origin, } \\
\text { and year }\end{array}$} & \multicolumn{3}{|c|}{ All people } & \multicolumn{6}{|c|}{ People in families } & \multicolumn{3}{|c|}{ Unrelated individuals } \\
\hline & \multirow[b]{3}{*}{ Total } & \multicolumn{2}{|c|}{ Below poverty } & \multicolumn{3}{|c|}{ All families } & \multicolumn{3}{|c|}{$\begin{array}{l}\text { Families with female } \\
\text { householder, no } \\
\text { husband present }\end{array}$} & \multirow[b]{3}{*}{ Total } & \multicolumn{2}{|c|}{ Below poverty } \\
\hline & & \multirow[b]{2}{*}{ Number } & \multirow[b]{2}{*}{ Percent } & \multirow[b]{2}{*}{ Total } & \multicolumn{2}{|c|}{ Below poverty } & \multirow[b]{2}{*}{ Total } & \multicolumn{2}{|c|}{ Below poverty } & & \multirow[b]{2}{*}{ Number } & \multirow[b]{2}{*}{ Percent } \\
\hline & & & & & Number & Percent & & Number & Percent & & & \\
\hline \multicolumn{13}{|l|}{ ALL RACES } \\
\hline $\begin{array}{l}2005 \ldots \\
2004^{1}\end{array}$ & $\begin{array}{l}293,135 \\
290,617\end{array}$ & $\begin{array}{l}36,950 \\
37,040\end{array}$ & $\begin{array}{l}12.6 \\
12.7\end{array}$ & $\begin{array}{l}242,389 \\
240,754\end{array}$ & $\begin{array}{l}26,068 \\
26,544\end{array}$ & $\begin{array}{l}10.8 \\
11.0\end{array}$ & $\begin{array}{l}42,244 \\
42,053\end{array}$ & $\begin{array}{l}13,153 \\
12,832\end{array}$ & $\begin{array}{l}31.1 \\
30.5\end{array}$ & $\begin{array}{l}49,526 \\
48,609\end{array}$ & $\begin{array}{r}10,425 \\
9,926\end{array}$ & $\begin{array}{l}21.1 \\
20.4\end{array}$ \\
\hline $\begin{array}{l}2003 \ldots \ldots \ldots \ldots \\
2002 \ldots \ldots \ldots \ldots \\
2001 \ldots \ldots \ldots \ldots \\
2000^{2} \ldots \ldots \ldots \ldots \\
1999^{3} \ldots \ldots \ldots \ldots\end{array}$ & $\begin{array}{l}287,699 \\
285,317 \\
281,475 \\
278,944 \\
276,208\end{array}$ & $\begin{array}{l}35,861 \\
34,570 \\
32,907 \\
31,581 \\
32,791\end{array}$ & $\begin{array}{l}12.5 \\
12.1 \\
11.7 \\
11.3 \\
11.9\end{array}$ & $\begin{array}{l}238,903 \\
236,921 \\
233,911 \\
231,909 \\
230,789\end{array}$ & $\begin{array}{l}25,684 \\
24,534 \\
23,215 \\
22,347 \\
23,830\end{array}$ & $\begin{array}{r}10.8 \\
10.4 \\
9.9 \\
9.6 \\
10.3\end{array}$ & $\begin{array}{l}41,311 \\
40,529 \\
39,261 \\
38,375 \\
38,580\end{array}$ & $\begin{array}{l}12,413 \\
11,657 \\
11,223 \\
10,926 \\
11,764\end{array}$ & $\begin{array}{l}30.0 \\
28.8 \\
28.6 \\
28.5 \\
30.5\end{array}$ & $\begin{array}{l}47,594 \\
47,156 \\
46,392 \\
45,624 \\
43,977\end{array}$ & $\begin{array}{l}9,713 \\
9,618 \\
9,226 \\
8,653 \\
8,400\end{array}$ & $\begin{array}{l}20.4 \\
20.4 \\
19.9 \\
19.0 \\
19.1\end{array}$ \\
\hline $\begin{array}{l}1998 \ldots \ldots \ldots \ldots \ldots \\
1997 \ldots \ldots \ldots \ldots \ldots \\
1996 \ldots \ldots \ldots \ldots \ldots \\
1995 \ldots \ldots \ldots \ldots \ldots \\
1994 \ldots \ldots \ldots \ldots \ldots\end{array}$ & $\begin{array}{l}271,059 \\
268,480 \\
266,218 \\
263,733 \\
261,616\end{array}$ & $\begin{array}{l}34,476 \\
35,574 \\
36,529 \\
36,425 \\
38,059\end{array}$ & $\begin{array}{l}12.7 \\
13.3 \\
13.7 \\
13.8 \\
14.5\end{array}$ & $\begin{array}{l}227,229 \\
225,369 \\
223,955 \\
222,792 \\
221,430\end{array}$ & $\begin{array}{l}25,370 \\
26,217 \\
27,376 \\
27,501 \\
28,985\end{array}$ & $\begin{array}{l}11.2 \\
11.6 \\
12.2 \\
12.3 \\
13.1\end{array}$ & $\begin{array}{l}39,000 \\
38,412 \\
38,584 \\
38,908 \\
37,253\end{array}$ & $\begin{array}{l}12,907 \\
13,494 \\
13,796 \\
14,205 \\
14,380\end{array}$ & $\begin{array}{l}33.1 \\
35.1 \\
35.8 \\
36.5 \\
38.6\end{array}$ & $\begin{array}{l}42,539 \\
41,672 \\
40,727 \\
39,484 \\
38,538\end{array}$ & $\begin{array}{l}8,478 \\
8,687 \\
8,452 \\
8,247 \\
8,287\end{array}$ & $\begin{array}{l}19.9 \\
20.8 \\
20.8 \\
20.9 \\
21.5\end{array}$ \\
\hline $\begin{array}{l}1993 \ldots \ldots \ldots \ldots \\
1992^{4} \ldots \ldots \ldots \ldots \ldots \\
1991^{5} \ldots \ldots \ldots \ldots \\
1990 \ldots \ldots \ldots \ldots \\
1989 \ldots \ldots \ldots \ldots\end{array}$ & $\begin{array}{l}259,278 \\
256,549 \\
251,192 \\
248,644 \\
245,992\end{array}$ & $\begin{array}{l}39,265 \\
38,014 \\
35,708 \\
33,585 \\
31,528\end{array}$ & $\begin{array}{l}15.1 \\
14.8 \\
14.2 \\
13.5 \\
12.8\end{array}$ & $\begin{array}{l}219,489 \\
217,936 \\
212,723 \\
210,967 \\
209,515\end{array}$ & $\begin{array}{l}29,927 \\
28,961 \\
27,143 \\
25,232 \\
24,066\end{array}$ & $\begin{array}{l}13.6 \\
13.3 \\
12.8 \\
12.0 \\
11.5\end{array}$ & $\begin{array}{l}37,861 \\
36,446 \\
34,795 \\
33,795 \\
32,525\end{array}$ & $\begin{array}{l}14,636 \\
14,205 \\
13,824 \\
12,578 \\
11,668\end{array}$ & $\begin{array}{l}38.7 \\
39.0 \\
39.7 \\
37.2 \\
35.9\end{array}$ & $\begin{array}{l}38,038 \\
36,842 \\
36,845 \\
36,056 \\
35,185\end{array}$ & $\begin{array}{l}8,388 \\
8,075 \\
7,773 \\
7,446 \\
6,760\end{array}$ & $\begin{array}{l}22.1 \\
21.9 \\
21.1 \\
20.7 \\
19.2\end{array}$ \\
\hline $\begin{array}{l}1988^{6} \ldots \ldots \ldots \ldots \\
1987^{6} \ldots \ldots \ldots \ldots \\
1986 \ldots \ldots \ldots \\
1985 \ldots \ldots \ldots \ldots \\
1984 \ldots \ldots \ldots \ldots\end{array}$ & $\begin{array}{l}243,530 \\
240,982 \\
238,554 \\
236,594 \\
233,816\end{array}$ & $\begin{array}{l}31,745 \\
32,221 \\
32,370 \\
33,064 \\
33,700\end{array}$ & $\begin{array}{l}13.0 \\
13.4 \\
13.6 \\
14.0 \\
14.4\end{array}$ & $\begin{array}{l}208,056 \\
206,877 \\
205,459 \\
203,963 \\
202,288\end{array}$ & $\begin{array}{l}24,048 \\
24,725 \\
24,754 \\
25,729 \\
26,458\end{array}$ & $\begin{array}{l}11.6 \\
12.0 \\
12.0 \\
12.6 \\
13.1\end{array}$ & $\begin{array}{l}32,164 \\
31,893 \\
31,152 \\
30,878 \\
30,844\end{array}$ & $\begin{array}{l}11,972 \\
12,148 \\
11,944 \\
11,600 \\
11,831\end{array}$ & $\begin{array}{l}37.2 \\
38.1 \\
38.3 \\
37.6 \\
38.4\end{array}$ & $\begin{array}{l}34,340 \\
32,992 \\
31,679 \\
31,351 \\
30,268\end{array}$ & $\begin{array}{l}7,070 \\
6,857 \\
6,846 \\
6,725 \\
6,609\end{array}$ & $\begin{array}{l}20.6 \\
20.8 \\
21.6 \\
21.5 \\
21.8\end{array}$ \\
\hline $\begin{array}{l}1983 \ldots \ldots \ldots \ldots \\
1982 \ldots \ldots \ldots \ldots \\
1981 \ldots \ldots \ldots \ldots \\
1980 \ldots \ldots \ldots \ldots \\
1979 \ldots \ldots \ldots \ldots\end{array}$ & $\begin{array}{l}231,700 \\
229,412 \\
227,157 \\
225,027 \\
222,903\end{array}$ & $\begin{array}{l}35,303 \\
34,398 \\
31,822 \\
29,272 \\
26,072\end{array}$ & $\begin{array}{l}15.2 \\
15.0 \\
14.0 \\
13.0 \\
11.7\end{array}$ & $\begin{array}{l}201,338 \\
200,385 \\
198,541 \\
196,963 \\
195,860\end{array}$ & $\begin{array}{l}27,933 \\
27,349 \\
24,850 \\
22,601 \\
19,964\end{array}$ & $\begin{array}{r}13.9 \\
13.6 \\
12.5 \\
11.5 \\
10.2\end{array}$ & $\begin{array}{l}30,049 \\
28,834 \\
28,587 \\
27,565 \\
26,927\end{array}$ & $\begin{array}{r}12,072 \\
11,701 \\
11,051 \\
10,120 \\
9,400\end{array}$ & $\begin{array}{l}40.2 \\
40.6 \\
38.7 \\
36.7 \\
34.9\end{array}$ & $\begin{array}{l}29,158 \\
27,908 \\
27,714 \\
27,133 \\
26,170\end{array}$ & $\begin{array}{l}6,740 \\
6,458 \\
6,490 \\
6,227 \\
5,743\end{array}$ & $\begin{array}{l}23.1 \\
23.1 \\
23.4 \\
22.9 \\
21.9\end{array}$ \\
\hline 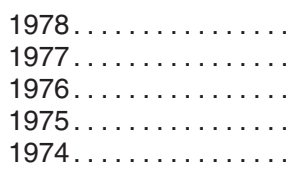 & $\begin{array}{l}215,656 \\
213,867 \\
212,303 \\
210,864 \\
209,362\end{array}$ & $\begin{array}{l}24,497 \\
24,720 \\
24,975 \\
25,877 \\
23,370\end{array}$ & $\begin{array}{l}11.4 \\
11.6 \\
11.8 \\
12.3 \\
11.2\end{array}$ & $\begin{array}{l}191,071 \\
190,757 \\
190,844 \\
190,630 \\
190,436\end{array}$ & $\begin{array}{l}19,062 \\
19,505 \\
19,632 \\
20,789 \\
18,817\end{array}$ & $\begin{array}{r}10.0 \\
10.2 \\
10.3 \\
10.9 \\
9.9\end{array}$ & $\begin{array}{l}26,032 \\
25,404 \\
24,204 \\
23,580 \\
23,165\end{array}$ & $\begin{array}{l}9,269 \\
9,205 \\
9,029 \\
8,846 \\
8,462\end{array}$ & $\begin{array}{l}35.6 \\
36.2 \\
37.3 \\
37.5 \\
36.5\end{array}$ & $\begin{array}{l}24,585 \\
23,110 \\
21,459 \\
20,234 \\
18,926\end{array}$ & $\begin{array}{l}5,435 \\
5,216 \\
5,344 \\
5,088 \\
4,553\end{array}$ & $\begin{array}{l}22.1 \\
22.6 \\
24.9 \\
25.1 \\
24.1\end{array}$ \\
\hline $\begin{array}{l}1973 \ldots \ldots \ldots \ldots \ldots \\
1972 \ldots \ldots \ldots \ldots \\
1971 \ldots \ldots \ldots \ldots \ldots \\
1970 \ldots \ldots \ldots \ldots \\
1969 \ldots \ldots \ldots \ldots \ldots\end{array}$ & $\begin{array}{l}207,621 \\
206,004 \\
204,554 \\
202,183 \\
199,517\end{array}$ & $\begin{array}{l}22,973 \\
24,460 \\
25,559 \\
25,420 \\
24,147\end{array}$ & $\begin{array}{l}11.1 \\
11.9 \\
12.5 \\
12.6 \\
12.1\end{array}$ & $\begin{array}{l}189,361 \\
189,193 \\
188,242 \\
186,692 \\
184,891\end{array}$ & $\begin{array}{l}18,299 \\
19,577 \\
20,405 \\
20,330 \\
19,175\end{array}$ & \begin{tabular}{r|}
9.7 \\
10.3 \\
10.8 \\
10.9 \\
10.4
\end{tabular} & $\begin{array}{l}21,823 \\
21,264 \\
20,153 \\
19,673 \\
17,995\end{array}$ & $\begin{array}{l}8,178 \\
8,114 \\
7,797 \\
7,503 \\
6,879\end{array}$ & $\begin{array}{l}37.5 \\
38.2 \\
38.7 \\
38.1 \\
38.2\end{array}$ & $\begin{array}{l}18,260 \\
16,811 \\
16,311 \\
15,491 \\
14,626\end{array}$ & $\begin{array}{l}4,674 \\
4,883 \\
5,154 \\
5,090 \\
4,972\end{array}$ & $\begin{array}{l}25.6 \\
29.0 \\
31.6 \\
32.9 \\
34.0\end{array}$ \\
\hline $\begin{array}{l}1968 \ldots \\
1967 \ldots \\
1966 \ldots \\
1965 \ldots \\
1964 \ldots\end{array}$ & $\begin{array}{l}197,628 \\
195,672 \\
193,388 \\
191,413 \\
189,710\end{array}$ & $\begin{array}{l}25,389 \\
27,769 \\
28,510 \\
33,185 \\
36,055\end{array}$ & $\begin{array}{l}12.8 \\
14.2 \\
14.7 \\
17.3 \\
19.0\end{array}$ & $\begin{array}{c}183,825 \\
182,558 \\
181,117 \\
179,281 \\
177,653\end{array}$ & $\begin{array}{l}20,695 \\
22,771 \\
23,809 \\
28,358 \\
30,912\end{array}$ & $\begin{array}{l}11.3 \\
12.5 \\
13.1 \\
15.8 \\
17.4\end{array}$ & $\begin{array}{r}18,048 \\
17,788 \\
17,240 \\
16,371 \\
(\mathrm{NA})\end{array}$ & $\begin{array}{l}6,990 \\
6,898 \\
6,861 \\
7,524 \\
7,297\end{array}$ & $\begin{array}{l}38.7 \\
38.8 \\
39.8 \\
46.0 \\
44.4\end{array}$ & $\begin{array}{l}13,803 \\
13,114 \\
12,271 \\
12,132 \\
12,057\end{array}$ & $\begin{array}{l}4,694 \\
4,998 \\
4,701 \\
4,827 \\
5,143\end{array}$ & $\begin{array}{l}34.0 \\
38.1 \\
38.3 \\
39.8 \\
42.7\end{array}$ \\
\hline $\begin{array}{l}1963 \ldots \ldots \ldots \ldots \\
1962 \ldots \ldots \ldots \ldots \\
1961 \ldots \ldots \ldots \\
1960 \ldots \ldots \ldots \\
1959 \ldots \ldots \ldots\end{array}$ & $\begin{array}{l}187,258 \\
184,276 \\
181,277 \\
179,503 \\
176,557\end{array}$ & $\begin{array}{l}36,436 \\
38,625 \\
39,628 \\
39,851 \\
39,490\end{array}$ & $\begin{array}{l}19.5 \\
21.0 \\
21.9 \\
22.2 \\
22.4\end{array}$ & $\begin{array}{l}176,076 \\
173,263 \\
170,131 \\
168,615 \\
165,858\end{array}$ & $\begin{array}{l}31,498 \\
33,623 \\
34,509 \\
34,925 \\
34,562\end{array}$ & $\begin{array}{l}17.9 \\
19.4 \\
20.3 \\
20.7 \\
20.8\end{array}$ & $\begin{array}{l}\text { (NA) } \\
\text { (NA) } \\
\text { (NA) } \\
\text { (NA) } \\
\text { (NA) }\end{array}$ & $\begin{array}{l}7,646 \\
7,781 \\
7,252 \\
7,247 \\
7,014\end{array}$ & $\begin{array}{l}47.7 \\
50.3 \\
48.1 \\
48.9 \\
49.4\end{array}$ & $\begin{array}{l}11,182 \\
11,013 \\
11,146 \\
10,888 \\
10,699\end{array}$ & $\begin{array}{l}4,938 \\
5,002 \\
5,119 \\
4,926 \\
4,928\end{array}$ & $\begin{array}{l}44.2 \\
45.4 \\
45.9 \\
45.2 \\
46.1\end{array}$ \\
\hline
\end{tabular}

See footnotes at end of table. 
Table B-1.

Poverty Status of People by Family Relationship, Race, and Hispanic Origin: 1959 to 2005 -Con. (Numbers in thousands. People as of March of the following year)

\begin{tabular}{|c|c|c|c|c|c|c|c|c|c|c|c|c|}
\hline \multirow{4}{*}{$\begin{array}{c}\text { Race, Hispanic origin, } \\
\text { and year }\end{array}$} & \multicolumn{3}{|c|}{ All people } & \multicolumn{6}{|c|}{ People in families } & \multicolumn{3}{|c|}{ Unrelated individuals } \\
\hline & \multirow[b]{3}{*}{ Total } & \multicolumn{2}{|c|}{ Below poverty } & \multicolumn{3}{|c|}{ All families } & \multicolumn{3}{|c|}{$\begin{array}{l}\text { Families with female } \\
\text { householder, no } \\
\text { husband present }\end{array}$} & \multirow[b]{3}{*}{ Total } & \multicolumn{2}{|c|}{ Below poverty } \\
\hline & & \multirow[b]{2}{*}{ Number } & \multirow[b]{2}{*}{ Percent } & \multirow[b]{2}{*}{ Total } & \multicolumn{2}{|c|}{ Below poverty } & \multirow[b]{2}{*}{ Total } & \multicolumn{2}{|c|}{ Below poverty } & & \multirow[b]{2}{*}{ Number } & \multirow[b]{2}{*}{ Percent } \\
\hline & & & & & Number & Percent & & Number & Percent & & & \\
\hline \multicolumn{13}{|l|}{ WHITE ALONE ${ }^{7}$} \\
\hline $\begin{array}{l}2005 \ldots \ldots \ldots \ldots \\
2004^{1} \ldots \ldots \ldots \ldots \ldots \\
2003 \ldots \ldots \ldots \ldots \ldots \\
2002 \ldots \ldots \ldots \ldots\end{array}$ & $\begin{array}{l}235,430 \\
233,741 \\
231,866 \\
230,376\end{array}$ & $\begin{array}{l}24,872 \\
25,327 \\
24,272 \\
23,466\end{array}$ & $\begin{array}{l}10.6 \\
10.8 \\
10.5 \\
10.2\end{array}$ & $\begin{array}{l}194,277 \\
193,024 \\
192,074 \\
190,823\end{array}$ & $\begin{array}{l}16,782 \\
17,445 \\
16,740 \\
16,043\end{array}$ & $\begin{array}{l}8.6 \\
9.0 \\
8.7 \\
8.4\end{array}$ & $\begin{array}{l}25,943 \\
26,139 \\
25,536 \\
24,903\end{array}$ & $\begin{array}{l}7,021 \\
6,892 \\
6,530 \\
5,992\end{array}$ & $\begin{array}{l}27.1 \\
26.4 \\
25.6 \\
24.1\end{array}$ & $\begin{array}{l}40,164 \\
39,712 \\
38,913 \\
38,575\end{array}$ & $\begin{array}{l}7,718 \\
7,416 \\
7,225 \\
7,105\end{array}$ & $\begin{array}{l}19.2 \\
18.7 \\
18.6 \\
18.4\end{array}$ \\
\hline \multicolumn{13}{|l|}{ WHITE ${ }^{8}$} \\
\hline $\begin{array}{l}2001 \\
2000^{2} \\
1999^{3}\end{array}$ & $\begin{array}{l}229,675 \\
227,846 \\
225,361\end{array}$ & $\begin{array}{l}22,739 \\
21,645 \\
22,169\end{array}$ & $\begin{array}{l}9.9 \\
9.5 \\
9.8\end{array}$ & $\begin{array}{l}190,413 \\
188,966 \\
187,833\end{array}$ & $\begin{array}{l}15,369 \\
14,692 \\
15,353\end{array}$ & $\begin{array}{l}8.1 \\
7.8 \\
8.2\end{array}$ & $\begin{array}{l}24,619 \\
24,166 \\
23,913\end{array}$ & $\begin{array}{l}5,972 \\
5,609 \\
5,947\end{array}$ & $\begin{array}{l}24.3 \\
23.2 \\
24.9\end{array}$ & $\begin{array}{l}38,294 \\
37,699 \\
36,441\end{array}$ & $\begin{array}{l}6,996 \\
6,454 \\
6,411\end{array}$ & $\begin{array}{l}18.3 \\
17.1 \\
17.6\end{array}$ \\
\hline $\begin{array}{l}1998 \ldots \\
1997 \ldots \\
1996 \ldots \\
1995 \ldots \\
1994 \ldots\end{array}$ & $\begin{array}{l}222,837 \\
221,200 \\
219,656 \\
218,028 \\
216,460\end{array}$ & $\begin{array}{l}23,454 \\
24,396 \\
24,650 \\
24,423 \\
25,379\end{array}$ & $\begin{array}{l}10.5 \\
11.0 \\
11.2 \\
11.2 \\
11.7\end{array}$ & $\begin{array}{c}186,184 \\
185,147 \\
184,119 \\
183,450 \\
182,546\end{array}$ & $\begin{array}{l}16,549 \\
17,258 \\
17,621 \\
17,593 \\
18,474\end{array}$ & \begin{tabular}{r|}
8.9 \\
9.3 \\
9.6 \\
9.6 \\
10.1
\end{tabular} & $\begin{array}{l}24,211 \\
23,773 \\
23,744 \\
23,732 \\
22,713\end{array}$ & $\begin{array}{l}6,674 \\
7,296 \\
7,073 \\
7,047 \\
7,228\end{array}$ & \begin{tabular}{l|}
27.6 \\
30.7 \\
29.8 \\
29.7 \\
31.8
\end{tabular} & $\begin{array}{l}35,563 \\
34,858 \\
34,247 \\
33,399 \\
32,569\end{array}$ & $\begin{array}{l}6,386 \\
6,593 \\
6,463 \\
6,336 \\
6,292\end{array}$ & $\begin{array}{l}18.0 \\
18.9 \\
18.9 \\
19.0 \\
19.3\end{array}$ \\
\hline $\begin{array}{l}1993 \ldots \\
1992^{4} \ldots \\
1991^{5} \ldots \\
1990 \ldots \\
1989 \ldots\end{array}$ & $\begin{array}{l}214,899 \\
213,060 \\
210,133 \\
208,611 \\
206,853\end{array}$ & $\begin{array}{l}26,226 \\
25,259 \\
23,747 \\
22,326 \\
20,785\end{array}$ & $\begin{array}{l}12.2 \\
11.9 \\
11.3 \\
10.7 \\
10.0\end{array}$ & $\begin{array}{l}181,330 \\
180,409 \\
177,619 \\
176,504 \\
175,857\end{array}$ & $\begin{array}{l}18,968 \\
18,294 \\
17,268 \\
15,916 \\
15,179\end{array}$ & \begin{tabular}{r|}
10.5 \\
10.1 \\
9.7 \\
9.0 \\
8.6
\end{tabular} & $\begin{array}{l}23,224 \\
22,453 \\
21,608 \\
20,845 \\
20,362\end{array}$ & $\begin{array}{l}7,199 \\
6,907 \\
6,806 \\
6,210 \\
5,723\end{array}$ & $\begin{array}{l}31.0 \\
30.8 \\
31.5 \\
29.8 \\
28.1\end{array}$ & $\begin{array}{l}32,112 \\
31,170 \\
31,207 \\
30,833 \\
29,993\end{array}$ & $\begin{array}{l}6,443 \\
6,147 \\
5,872 \\
5,739 \\
5,063\end{array}$ & $\begin{array}{l}20.1 \\
19.7 \\
18.8 \\
18.6 \\
16.9\end{array}$ \\
\hline $\begin{array}{l}1988^{6} \ldots \\
1987^{6} \ldots \\
1986 \ldots \\
1985 \ldots \\
1984 \ldots\end{array}$ & $\begin{array}{l}205,235 \\
203,605 \\
202,282 \\
200,918 \\
198,941\end{array}$ & $\begin{array}{l}20,715 \\
21,195 \\
22,183 \\
22,860 \\
22,955\end{array}$ & $\begin{array}{l}10.1 \\
10.4 \\
11.0 \\
11.4 \\
11.5\end{array}$ & $\begin{array}{r}175,111 \\
174,488 \\
174,024 \\
172,863 \\
171,839\end{array}$ & $\begin{array}{l}15,001 \\
15,593 \\
16,393 \\
17,125 \\
17,299\end{array}$ & \begin{tabular}{r|}
8.6 \\
8.9 \\
9.4 \\
9.9 \\
10.1
\end{tabular} & $\begin{array}{l}20,396 \\
20,244 \\
20,163 \\
20,105 \\
19,727\end{array}$ & $\begin{array}{l}5,950 \\
5,989 \\
6,171 \\
5,990 \\
5,866\end{array}$ & \begin{tabular}{l|}
29.2 \\
29.6 \\
30.6 \\
29.8 \\
29.7
\end{tabular} & $\begin{array}{l}29,315 \\
28,290 \\
27,143 \\
27,067 \\
26,094\end{array}$ & $\begin{array}{l}5,314 \\
5,174 \\
5,198 \\
5,299 \\
5,181\end{array}$ & $\begin{array}{l}18.1 \\
18.3 \\
19.2 \\
19.6 \\
19.9\end{array}$ \\
\hline $\begin{array}{l}1983 \ldots \\
1982 \ldots \\
1981 \ldots \\
1980 \ldots \\
1979 \ldots\end{array}$ & $\begin{array}{l}197,496 \\
195,919 \\
194,504 \\
192,912 \\
191,742\end{array}$ & $\begin{array}{l}23,984 \\
23,517 \\
21,553 \\
19,699 \\
17,214\end{array}$ & $\begin{array}{r}12.1 \\
12.0 \\
11.1 \\
10.2 \\
9.0\end{array}$ & $\begin{array}{l}171,407 \\
170,748 \\
169,868 \\
168,756 \\
168,461\end{array}$ & $\begin{array}{l}18,377 \\
18,015 \\
16,127 \\
14,587 \\
12,495\end{array}$ & \begin{tabular}{r|}
10.7 \\
10.6 \\
9.5 \\
8.6 \\
7.4
\end{tabular} & $\begin{array}{l}19,256 \\
18,374 \\
18,795 \\
17,642 \\
17,349\end{array}$ & $\begin{array}{l}6,017 \\
5,686 \\
5,600 \\
4,940 \\
4,375\end{array}$ & $\begin{array}{l}31.2 \\
30.9 \\
29.8 \\
28.0 \\
25.2\end{array}$ & $\begin{array}{l}25,206 \\
24,300 \\
23,913 \\
23,370 \\
22,587\end{array}$ & $\begin{array}{l}5,189 \\
5,041 \\
5,061 \\
4,760 \\
4,452\end{array}$ & $\begin{array}{l}20.6 \\
20.7 \\
21.2 \\
20.4 \\
19.7\end{array}$ \\
\hline $\begin{array}{l}1978 \ldots \\
1977 \ldots \\
1976 \ldots \\
1975 \ldots \\
1974 \ldots\end{array}$ & $\begin{array}{l}186,450 \\
185,254 \\
184,165 \\
183,164 \\
182,376\end{array}$ & $\begin{array}{l}16,259 \\
16,416 \\
16,713 \\
17,770 \\
15,736\end{array}$ & $\begin{array}{l}8.7 \\
8.9 \\
9.1 \\
9.7 \\
8.6\end{array}$ & $\begin{array}{l}165,193 \\
165,385 \\
165,571 \\
165,661 \\
166,081\end{array}$ & $\begin{array}{l}12,050 \\
12,364 \\
12,500 \\
13,799 \\
12,181\end{array}$ & $\begin{array}{l}7.3 \\
7.5 \\
7.5 \\
8.3 \\
7.3\end{array}$ & $\begin{array}{l}16,877 \\
16,721 \\
15,941 \\
15,577 \\
15,433\end{array}$ & $\begin{array}{l}4,371 \\
4,474 \\
4,463 \\
4,577 \\
4,278\end{array}$ & \begin{tabular}{l|}
25.9 \\
26.8 \\
28.0 \\
29.4 \\
27.7
\end{tabular} & $\begin{array}{l}21,257 \\
19,869 \\
18,594 \\
17,503 \\
16,295\end{array}$ & $\begin{array}{l}4,209 \\
4,051 \\
4,213 \\
3,972 \\
3,555\end{array}$ & $\begin{array}{l}19.8 \\
20.4 \\
22.7 \\
22.7 \\
21.8\end{array}$ \\
\hline $\begin{array}{l}1973 \ldots \ldots \ldots \ldots \\
1972 \ldots \ldots \ldots \ldots \\
1971 \ldots \ldots \ldots \ldots \\
1970 \ldots \ldots \ldots \ldots \\
1969 \ldots \ldots \ldots \ldots\end{array}$ & $\begin{array}{l}181,185 \\
180,125 \\
179,398 \\
177,376 \\
175,349\end{array}$ & $\begin{array}{l}15,142 \\
16,203 \\
17,780 \\
17,484 \\
16,659\end{array}$ & $\begin{array}{l}8.4 \\
9.0 \\
9.9 \\
9.9 \\
9.5\end{array}$ & $\begin{array}{l}165,424 \\
165,630 \\
165,184 \\
163,875 \\
162,779\end{array}$ & $\begin{array}{l}11,412 \\
12,268 \\
13,566 \\
13,323 \\
12,623\end{array}$ & $\begin{array}{l}6.9 \\
7.4 \\
8.2 \\
8.1 \\
7.8\end{array}$ & $\begin{array}{l}14,303 \\
13,739 \\
13,502 \\
13,226 \\
12,285\end{array}$ & $\begin{array}{l}4,003 \\
3,770 \\
4,099 \\
3,761 \\
3,577\end{array}$ & $\begin{array}{l}28.0 \\
27.4 \\
30.4 \\
28.4 \\
29.1\end{array}$ & $\begin{array}{l}15,761 \\
14,495 \\
14,214 \\
13,500 \\
12,570\end{array}$ & $\begin{array}{l}3,730 \\
3,935 \\
4,214 \\
4,161 \\
4,036\end{array}$ & $\begin{array}{l}23.7 \\
27.1 \\
29.6 \\
30.8 \\
32.1\end{array}$ \\
\hline $\begin{array}{l}1968 \ldots \\
1967 \ldots \\
1966 \ldots \\
1965 \ldots \\
1964 \ldots\end{array}$ & $\begin{array}{l}173,732 \\
172,038 \\
170,247 \\
168,732 \\
167,313\end{array}$ & $\begin{array}{l}17,395 \\
18,983 \\
19,290 \\
22,496 \\
24,957\end{array}$ & $\begin{array}{l}10.0 \\
11.0 \\
11.3 \\
13.3 \\
14.9\end{array}$ & $\begin{array}{l}161,777 \\
160,720 \\
159,561 \\
158,255 \\
156,898\end{array}$ & $\begin{array}{l}13,546 \\
14,851 \\
15,430 \\
18,508 \\
20,716\end{array}$ & \begin{tabular}{r|}
8.4 \\
9.2 \\
9.7 \\
11.7 \\
13.2
\end{tabular} & $\begin{array}{r}12,190 \\
12,131 \\
12,261 \\
11,573 \\
(\mathrm{NA})\end{array}$ & $\begin{array}{l}3,551 \\
3,453 \\
3,646 \\
4,092 \\
3,911\end{array}$ & $\begin{array}{l}29.1 \\
28.5 \\
29.7 \\
35.4 \\
33.4\end{array}$ & $\begin{array}{l}11,955 \\
11,318 \\
10,686 \\
10,477 \\
10,415\end{array}$ & $\begin{array}{l}3,849 \\
4,132 \\
3,860 \\
3,988 \\
4,241\end{array}$ & $\begin{array}{l}32.2 \\
36.5 \\
36.1 \\
38.1 \\
40.7\end{array}$ \\
\hline $\begin{array}{l}1963 \ldots \ldots \ldots \ldots \ldots \\
1962 \ldots \ldots \ldots \ldots \ldots \\
1961 \ldots \ldots \ldots \ldots \\
1960 \ldots \ldots \ldots \ldots \ldots \\
1959 \ldots \ldots \ldots \ldots \ldots\end{array}$ & $\begin{array}{l}165,309 \\
162,842 \\
160,306 \\
158,863 \\
156,956\end{array}$ & $\begin{array}{l}25,238 \\
26,672 \\
27,890 \\
28,309 \\
28,484\end{array}$ & $\begin{array}{l}15.3 \\
16.4 \\
17.4 \\
17.8 \\
18.1\end{array}$ & $\begin{array}{l}155,584 \\
153,348 \\
150,717 \\
149,458 \\
147,802\end{array}$ & $\begin{array}{l}21,149 \\
22,613 \\
23,747 \\
24,262 \\
24,443\end{array}$ & $\begin{array}{l}13.6 \\
14.7 \\
15.8 \\
16.2 \\
16.5\end{array}$ & $\begin{array}{l}(\mathrm{NA}) \\
(\mathrm{NA}) \\
(\mathrm{NA}) \\
(\mathrm{NA}) \\
(\mathrm{NA})\end{array}$ & $\begin{array}{l}4,051 \\
4,089 \\
4,062 \\
4,296 \\
4,232\end{array}$ & $\begin{array}{l}35.6 \\
37.9 \\
37.6 \\
39.0 \\
40.2\end{array}$ & $\begin{array}{l}9,725 \\
9,494 \\
9,589 \\
9,405 \\
9,154\end{array}$ & $\begin{array}{l}4,089 \\
4,059 \\
4,143 \\
4,047 \\
4,041\end{array}$ & $\begin{array}{l}42.0 \\
42.7 \\
43.2 \\
43.0 \\
44.1\end{array}$ \\
\hline
\end{tabular}

See footnotes at end of table. 
Table B-1.

Poverty Status of People by Family Relationship, Race, and Hispanic Origin: 1959 to 2005-Con. (Numbers in thousands. People as of March of the following year)

\begin{tabular}{|c|c|c|c|c|c|c|c|c|c|c|c|c|}
\hline \multirow{4}{*}{$\begin{array}{l}\text { Race, Hispanic origin, } \\
\text { and year }\end{array}$} & \multicolumn{3}{|c|}{ All people } & \multicolumn{6}{|c|}{ People in families } & \multicolumn{3}{|c|}{ Unrelated individuals } \\
\hline & \multirow[b]{3}{*}{ Total } & \multicolumn{2}{|c|}{ Below poverty } & \multicolumn{3}{|c|}{ All families } & \multicolumn{3}{|c|}{$\begin{array}{c}\text { Families with female } \\
\text { householder, no } \\
\text { husband present }\end{array}$} & \multirow[b]{3}{*}{ Total } & \multicolumn{2}{|c|}{ Below poverty } \\
\hline & & \multirow[b]{2}{*}{ Number } & \multirow[b]{2}{*}{ Percent } & \multirow[b]{2}{*}{ Total } & \multicolumn{2}{|c|}{ Below poverty } & \multirow[b]{2}{*}{ Total } & \multicolumn{2}{|c|}{ Below poverty } & & \multirow[b]{2}{*}{ Number } & \multirow[b]{2}{*}{ Percent } \\
\hline & & & & & Number & Percent & & Number & Percent & & & \\
\hline \multicolumn{13}{|l|}{$\begin{array}{l}\text { WHITE ALONE, NOT } \\
\text { HISPANIC }^{7}\end{array}$} \\
\hline $\begin{array}{l}2005 \ldots \ldots \ldots \ldots \ldots \\
2004^{1} \ldots \ldots \ldots \ldots \ldots \ldots \\
2003 \ldots \ldots \ldots \ldots \ldots \\
2002 \ldots \ldots \ldots \ldots \ldots\end{array}$ & $\begin{array}{l}195,553 \\
195,098 \\
194,595 \\
194,144\end{array}$ & $\begin{array}{l}16,227 \\
16,908 \\
15,902 \\
15,567\end{array}$ & $\begin{array}{l}8.3 \\
8.7 \\
8.2 \\
8.0\end{array}$ & $\begin{array}{l}159,204 \\
159,221 \\
159,215 \\
158,764\end{array}$ & $\begin{array}{r}9,604 \\
10,323 \\
9,658 \\
9,389\end{array}$ & $\begin{array}{l}6.0 \\
6.5 \\
6.1 \\
5.9\end{array}$ & $\begin{array}{l}18,899 \\
19,009 \\
18,792 \\
18,664\end{array}$ & $\begin{array}{l}4,278 \\
4,116 \\
3,959 \\
3,733\end{array}$ & $\begin{array}{l}22.6 \\
21.7 \\
21.1 \\
20.0\end{array}$ & $\begin{array}{l}35,626 \\
35,141 \\
34,683 \\
34,614\end{array}$ & $\begin{array}{l}6,393 \\
6,237 \\
6,015 \\
5,947\end{array}$ & $\begin{array}{l}17.9 \\
17.7 \\
17.3 \\
17.2\end{array}$ \\
\hline \multicolumn{13}{|l|}{$\begin{array}{l}\text { WHITE, NOT } \\
\text { HISPANIC }^{8}\end{array}$} \\
\hline $\begin{array}{l}2001 \ldots \\
2000^{2} \ldots \\
1999^{3} \ldots \\
1998 \ldots\end{array}$ & $\begin{array}{l}194,538 \\
193,691 \\
192,565 \\
192,754\end{array}$ & $\begin{array}{l}15,271 \\
14,366 \\
14,735 \\
15,799\end{array}$ & $\begin{array}{l}7.8 \\
7.4 \\
7.7 \\
8.2\end{array}$ & $\begin{array}{l}159,178 \\
158,838 \\
158,550 \\
159,301\end{array}$ & $\begin{array}{r}9,122 \\
8,664 \\
9,013 \\
10,061\end{array}$ & $\begin{array}{l}5.7 \\
5.5 \\
5.7 \\
6.3\end{array}$ & $\begin{array}{l}18,365 \\
18,196 \\
17,892 \\
18,547\end{array}$ & $\begin{array}{l}3,661 \\
3,412 \\
3,545 \\
4,074\end{array}$ & $\begin{array}{l}19.9 \\
18.8 \\
19.8 \\
22.0\end{array}$ & $\begin{array}{l}34,603 \\
33,943 \\
33,189 \\
32,573\end{array}$ & $\begin{array}{l}5,882 \\
5,356 \\
5,412 \\
5,352\end{array}$ & $\begin{array}{l}17.0 \\
15.8 \\
16.3 \\
16.4\end{array}$ \\
\hline $\begin{array}{l}1997 \ldots \ldots \ldots \ldots \\
1996 \ldots \ldots \ldots \ldots \ldots \\
1995 \ldots \ldots \ldots \ldots \\
1994 \ldots \ldots \ldots \ldots \ldots \\
1993 \ldots \ldots \ldots \ldots \ldots\end{array}$ & $\begin{array}{l}191,859 \\
191,459 \\
190,951 \\
192,543 \\
190,843\end{array}$ & $\begin{array}{r}16,491 \\
16,462 \\
16,267 \\
18,110 \\
18,882\end{array}$ & $\begin{array}{l}8.6 \\
8.6 \\
8.5 \\
9.4 \\
9.9\end{array}$ & $\begin{array}{l}158,796 \\
159,044 \\
159,402 \\
161,254 \\
160,062\end{array}$ & $\begin{array}{l}10,401 \\
10,553 \\
10,599 \\
12,118 \\
12,756\end{array}$ & $\begin{array}{l}6.5 \\
6.6 \\
6.6 \\
7.5 \\
8.0\end{array}$ & $\begin{array}{l}18,474 \\
18,597 \\
18,340 \\
18,186 \\
18,508\end{array}$ & $\begin{array}{l}4,604 \\
4,339 \\
4,183 \\
4,743 \\
4,724\end{array}$ & $\begin{array}{l}24.9 \\
23.3 \\
22.8 \\
26.1 \\
25.5\end{array}$ & $\begin{array}{l}32,049 \\
31,410 \\
30,586 \\
30,157 \\
29,681\end{array}$ & $\begin{array}{l}5,632 \\
5,455 \\
5,303 \\
5,500 \\
5,570\end{array}$ & $\begin{array}{l}17.6 \\
17.4 \\
17.3 \\
18.2 \\
18.8\end{array}$ \\
\hline $\begin{array}{l}1992^{4} . \\
1991^{5} \\
1990 \\
1989 \\
1988^{6}\end{array}$ & $\begin{array}{l}189,001 \\
189,116 \\
188,129 \\
186,979 \\
185,961\end{array}$ & $\begin{array}{l}18,202 \\
17,741 \\
16,622 \\
15,599 \\
15,565\end{array}$ & $\begin{array}{l}9.6 \\
9.4 \\
8.8 \\
8.3 \\
8.4\end{array}$ & $\begin{array}{l}159,102 \\
158,850 \\
158,394 \\
158,127 \\
157,687\end{array}$ & $\begin{array}{l}12,277 \\
11,998 \\
11,086 \\
10,723 \\
10,467\end{array}$ & $\begin{array}{l}7.7 \\
7.6 \\
7.0 \\
6.8 \\
6.6\end{array}$ & $\begin{array}{l}18,016 \\
17,609 \\
17,160 \\
16,827 \\
16,828\end{array}$ & $\begin{array}{l}4,640 \\
4,710 \\
4,284 \\
3,922 \\
3,988\end{array}$ & $\begin{array}{l}25.8 \\
26.7 \\
25.0 \\
23.3 \\
23.7\end{array}$ & $\begin{array}{l}28,775 \\
29,215 \\
28,688 \\
28,055 \\
27,552\end{array}$ & $\begin{array}{l}5,350 \\
5,261 \\
5,002 \\
4,466 \\
4,746\end{array}$ & $\begin{array}{l}18.6 \\
18.0 \\
17.4 \\
15.9 \\
17.2\end{array}$ \\
\hline $\begin{array}{l}1987^{6} \\
1986 \ldots \\
1985 \\
1984 \ldots \\
1983 \ldots\end{array}$ & $\begin{array}{l}184,936 \\
184,119 \\
183,455 \\
182,469 \\
181,393\end{array}$ & $\begin{array}{l}16,029 \\
17,244 \\
17,839 \\
18,300 \\
19,538\end{array}$ & $\begin{array}{r}8.7 \\
9.4 \\
9.7 \\
10.0 \\
10.8\end{array}$ & $\begin{array}{l}157,785 \\
157,665 \\
157,106 \\
156,930 \\
156,719\end{array}$ & $\begin{array}{l}11,051 \\
12,078 \\
12,706 \\
13,234 \\
14,437\end{array}$ & $\begin{array}{l}7.0 \\
7.7 \\
8.1 \\
8.4 \\
9.2\end{array}$ & $\begin{array}{l}16,787 \\
16,739 \\
16,749 \\
16,742 \\
16,369\end{array}$ & $\begin{array}{l}4,075 \\
4,350 \\
4,136 \\
4,193 \\
4,448\end{array}$ & $\begin{array}{l}24.3 \\
26.0 \\
24.7 \\
25.0 \\
27.2\end{array}$ & $\begin{array}{l}26,439 \\
25,525 \\
25,544 \\
24,671 \\
23,894\end{array}$ & $\begin{array}{l}4,613 \\
4,668 \\
4,789 \\
4,659 \\
4,746\end{array}$ & $\begin{array}{l}17.4 \\
18.3 \\
18.7 \\
18.9 \\
19.9\end{array}$ \\
\hline $\begin{array}{l}1982 \ldots \ldots \ldots \ldots \\
1981 \ldots \ldots \ldots \ldots \ldots \\
1980 \ldots \ldots \ldots \ldots \\
1979 \ldots \ldots \ldots \ldots \\
1978 \ldots \ldots \ldots \ldots \ldots\end{array}$ & $\begin{array}{l}181,903 \\
180,909 \\
179,798 \\
178,814 \\
174,731\end{array}$ & $\begin{array}{l}19,362 \\
17,987 \\
16,365 \\
14,419 \\
13,755\end{array}$ & $\begin{array}{r}10.6 \\
9.9 \\
9.1 \\
8.1 \\
7.9\end{array}$ & $\begin{array}{l}157,818 \\
157,330 \\
156,633 \\
156,567 \\
154,321\end{array}$ & \begin{tabular}{r|}
14,271 \\
12,903 \\
11,568 \\
10,009 \\
9,798
\end{tabular} & $\begin{array}{l}9.0 \\
8.2 \\
7.4 \\
6.4 \\
6.3\end{array}$ & $\begin{array}{l}15,830 \\
16,323 \\
15,358 \\
15,410 \\
15,132\end{array}$ & $\begin{array}{l}4,161 \\
4,222 \\
3,699 \\
3,371 \\
3,390\end{array}$ & $\begin{array}{l}26.3 \\
25.9 \\
24.1 \\
21.9 \\
22.4\end{array}$ & $\begin{array}{l}23,329 \\
22,950 \\
22,455 \\
21,638 \\
20,410\end{array}$ & $\begin{array}{l}4,701 \\
4,769 \\
4,474 \\
4,179 \\
3,957\end{array}$ & $\begin{array}{l}20.2 \\
20.8 \\
19.9 \\
19.3 \\
19.4\end{array}$ \\
\hline $\begin{array}{l}1977 . . \\
1976 \ldots \\
1975 . . \\
1974 \ldots \\
1973 . .\end{array}$ & $\begin{array}{l}173,563 \\
173,235 \\
172,417 \\
171,463 \\
170,488\end{array}$ & $\begin{array}{l}13,802 \\
14,025 \\
14,883 \\
13,217 \\
12,864\end{array}$ & $\begin{array}{l}8.0 \\
8.1 \\
8.6 \\
7.7 \\
7.5\end{array}$ & $\begin{array}{l}154,449 \\
155,324 \\
155,539 \\
155,764 \\
155,330\end{array}$ & $\begin{array}{r}9,977 \\
10,066 \\
11,137 \\
9,854 \\
9,262\end{array}$ & $\begin{array}{l}6.5 \\
6.5 \\
7.2 \\
6.3 \\
6.0\end{array}$ & $\begin{array}{l}14,888 \\
14,261 \\
13,809 \\
13,763 \\
12,731\end{array}$ & $\begin{array}{l}3,429 \\
3,516 \\
3,570 \\
3,379 \\
3,185\end{array}$ & \begin{tabular}{l|}
23.0 \\
24.7 \\
25.9 \\
24.6 \\
25.0
\end{tabular} & $\begin{array}{l}19,114 \\
17,912 \\
16,879 \\
15,699 \\
15,158\end{array}$ & $\begin{array}{l}3,825 \\
3,959 \\
3,746 \\
3,364 \\
3,602\end{array}$ & $\begin{array}{l}20.0 \\
22.1 \\
22.2 \\
21.4 \\
23.8\end{array}$ \\
\hline
\end{tabular}

See footnotes at end of table. 
Table B-1.

Poverty Status of People by Family Relationship, Race, and Hispanic Origin: 1959 to 2005-Con. (Numbers in thousands. People as of March of the following year)

\begin{tabular}{|c|c|c|c|c|c|c|c|c|c|c|c|c|}
\hline \multirow{4}{*}{$\begin{array}{c}\text { Race, Hispanic origin, } \\
\text { and year }\end{array}$} & \multicolumn{3}{|c|}{ All people } & \multicolumn{6}{|c|}{ People in families } & \multicolumn{3}{|c|}{ Unrelated individuals } \\
\hline & \multirow[b]{3}{*}{ Total } & \multicolumn{2}{|c|}{ Below poverty } & \multicolumn{3}{|c|}{ All families } & \multicolumn{3}{|c|}{$\begin{array}{l}\text { Families with female } \\
\text { householder, no } \\
\text { husband present }\end{array}$} & \multirow[b]{3}{*}{ Total } & \multicolumn{2}{|c|}{ Below poverty } \\
\hline & & \multirow[b]{2}{*}{ Number } & \multirow[b]{2}{*}{ Percent } & \multirow[b]{2}{*}{ Total } & \multicolumn{2}{|c|}{ Below poverty } & \multirow[b]{2}{*}{ Total } & \multicolumn{2}{|c|}{ Below poverty } & & \multirow[b]{2}{*}{ Number } & \multirow[b]{2}{*}{ Percent } \\
\hline & & & & & Number & Percent & & Number & Percent & & & \\
\hline \multicolumn{13}{|l|}{$\begin{array}{l}\text { BLACK ALONE OR } \\
\text { IN COMBINATION }\end{array}$} \\
\hline $\begin{array}{l}2005 \ldots \ldots \ldots \ldots \\
2004^{1} \ldots \ldots \ldots \ldots \ldots \\
2003 \ldots \ldots \ldots \\
2002 \ldots \ldots \ldots \ldots \\
\end{array}$ & $\begin{array}{l}38,551 \\
38,037 \\
37,503 \\
37,207\end{array}$ & $\begin{array}{l}9,517 \\
9,411 \\
9,108 \\
8,884\end{array}$ & $\begin{array}{l}24.7 \\
24.7 \\
24.3 \\
23.9\end{array}$ & $\begin{array}{l}31,663 \\
31,468 \\
31,059 \\
31,008\end{array}$ & $\begin{array}{l}7,459 \\
7,495 \\
7,162 \\
6,985\end{array}$ & $\begin{array}{l}23.6 \\
23.8 \\
23.1 \\
22.5\end{array}$ & $\begin{array}{l}14,080 \\
13,830 \\
13,664 \\
13,551\end{array}$ & $\begin{array}{l}5,524 \\
5,484 \\
5,312 \\
5,145\end{array}$ & $\begin{array}{l}39.2 \\
39.7 \\
38.9 \\
38.0\end{array}$ & $\begin{array}{l}6,754 \\
6,418 \\
6,194 \\
6,034\end{array}$ & $\begin{array}{l}2,003 \\
1,840 \\
1,814 \\
1,851\end{array}$ & $\begin{array}{l}29.7 \\
28.7 \\
29.3 \\
30.7\end{array}$ \\
\hline \multicolumn{13}{|l|}{ BLACK ALONE $^{9}$} \\
\hline $\begin{array}{l}2005 \ldots \ldots \ldots \ldots \ldots \\
2004^{1} \ldots \ldots \ldots \ldots \ldots \ldots \\
2003 \ldots \ldots \ldots \ldots \\
2002 \ldots \ldots \ldots \ldots \ldots\end{array}$ & $\begin{array}{l}36,802 \\
36,426 \\
35,989 \\
35,678\end{array}$ & $\begin{array}{l}9,168 \\
9,014 \\
8,781 \\
8,602\end{array}$ & $\begin{array}{l}24.9 \\
24.7 \\
24.4 \\
24.1\end{array}$ & $\begin{array}{l}30,154 \\
30,065 \\
29,727 \\
29,671\end{array}$ & $\begin{array}{l}7,164 \\
7,153 \\
6,870 \\
6,761\end{array}$ & $\begin{array}{l}23.8 \\
23.8 \\
23.1 \\
22.8\end{array}$ & $\begin{array}{l}13,481 \\
13,244 \\
13,118 \\
13,030\end{array}$ & $\begin{array}{l}5,303 \\
5,247 \\
5,115 \\
4,980\end{array}$ & $\begin{array}{l}39.3 \\
39.6 \\
39.0 \\
38.2\end{array}$ & $\begin{array}{l}6,521 \\
6,217 \\
6,034 \\
5,858\end{array}$ & $\begin{array}{l}1,949 \\
1,792 \\
1,781 \\
1,800\end{array}$ & $\begin{array}{l}29.9 \\
28.8 \\
29.5 \\
30.7\end{array}$ \\
\hline \multicolumn{13}{|l|}{ BLACK $^{8}$} \\
\hline $\begin{array}{l}2001 \ldots \ldots \ldots \ldots \\
2000^{2} \ldots \ldots \ldots \ldots \ldots \\
1999^{3} \ldots \ldots \ldots \ldots \ldots \\
1998 \ldots \ldots \ldots \ldots\end{array}$ & $\begin{array}{l}35,871 \\
35,425 \\
35,756 \\
34,877\end{array}$ & $\begin{array}{l}8,136 \\
7,982 \\
8,441 \\
9,091\end{array}$ & $\begin{array}{l}22.7 \\
22.5 \\
23.6 \\
26.1\end{array}$ & $\begin{array}{l}29,869 \\
29,378 \\
29,819 \\
29,333\end{array}$ & $\begin{array}{l}6,389 \\
6,221 \\
6,758 \\
7,259\end{array}$ & $\begin{array}{l}21.4 \\
21.2 \\
22.7 \\
24.7\end{array}$ & $\begin{array}{l}12,550 \\
12,383 \\
12,823 \\
13,156\end{array}$ & $\begin{array}{l}4,694 \\
4,774 \\
5,232 \\
5,629\end{array}$ & $\begin{array}{l}37.4 \\
38.6 \\
40.8 \\
42.8\end{array}$ & $\begin{array}{l}5,873 \\
5,885 \\
5,668 \\
5,390\end{array}$ & $\begin{array}{l}1,692 \\
1,702 \\
1,562 \\
1,752\end{array}$ & $\begin{array}{l}28.8 \\
28.9 \\
27.5 \\
32.5\end{array}$ \\
\hline $\begin{array}{l}1997 \ldots \ldots \ldots \ldots \\
1996 \ldots \ldots \ldots \ldots \\
1995 \ldots \ldots \ldots \ldots \\
1994 \ldots \ldots \ldots \ldots \\
1993 \ldots \ldots \ldots \ldots \ldots\end{array}$ & $\begin{array}{l}34,458 \\
34,110 \\
33,740 \\
33,353 \\
32,910\end{array}$ & $\begin{array}{r}9,116 \\
9,694 \\
9,872 \\
10,196 \\
10,877\end{array}$ & $\begin{array}{l}26.5 \\
28.4 \\
29.3 \\
30.6 \\
33.1\end{array}$ & $\begin{array}{l}28,962 \\
28,933 \\
28,777 \\
28,499 \\
28,106\end{array}$ & $\begin{array}{l}7,386 \\
7,993 \\
8,189 \\
8,447 \\
9,242\end{array}$ & $\begin{array}{l}25.5 \\
27.6 \\
28.5 \\
29.6 \\
32.9\end{array}$ & $\begin{array}{l}13,218 \\
13,193 \\
13,604 \\
12,926 \\
13,132\end{array}$ & $\begin{array}{l}5,654 \\
6,123 \\
6,553 \\
6,489 \\
6,955\end{array}$ & $\begin{array}{l}42.8 \\
46.4 \\
48.2 \\
50.2 \\
53.0\end{array}$ & $\begin{array}{l}5,316 \\
4,989 \\
4,756 \\
4,649 \\
4,608\end{array}$ & $\begin{array}{l}1,645 \\
1,606 \\
1,551 \\
1,617 \\
1,541\end{array}$ & $\begin{array}{l}31.0 \\
32.2 \\
32.6 \\
34.8 \\
33.4\end{array}$ \\
\hline $\begin{array}{l}1992^{4} . \\
1991^{5} . \\
1990 . \\
1989 . \\
1988^{6}\end{array}$ & $\begin{array}{l}32,411 \\
31,313 \\
30,806 \\
30,332 \\
29,849\end{array}$ & $\begin{array}{r}10,827 \\
10,242 \\
9,837 \\
9,302 \\
9,356\end{array}$ & $\begin{array}{l}33.4 \\
32.7 \\
31.9 \\
30.7 \\
31.3\end{array}$ & $\begin{array}{l}27,790 \\
26,565 \\
26,296 \\
25,931 \\
25,484\end{array}$ & $\begin{array}{l}9,134 \\
8,504 \\
8,160 \\
7,704 \\
7,650\end{array}$ & $\begin{array}{l}32.9 \\
32.0 \\
31.0 \\
29.7 \\
30.0\end{array}$ & $\begin{array}{l}12,591 \\
11,960 \\
11,866 \\
11,190 \\
10,794\end{array}$ & $\begin{array}{l}6,799 \\
6,557 \\
6,005 \\
5,530 \\
5,601\end{array}$ & $\begin{array}{l}54.0 \\
54.8 \\
50.6 \\
49.4 \\
51.9\end{array}$ & $\begin{array}{l}4,410 \\
4,505 \\
4,244 \\
4,180 \\
4,095\end{array}$ & $\begin{array}{l}1,569 \\
1,590 \\
1,491 \\
1,471 \\
1,509\end{array}$ & $\begin{array}{l}35.6 \\
35.3 \\
35.1 \\
35.2 \\
36.8\end{array}$ \\
\hline 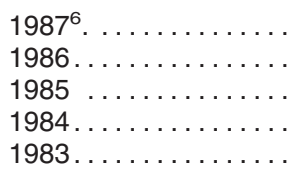 & $\begin{array}{l}29,362 \\
28,871 \\
28,485 \\
28,087 \\
27,678\end{array}$ & $\begin{array}{l}9,520 \\
8,983 \\
8,926 \\
9,490 \\
9,882\end{array}$ & $\begin{array}{l}32.4 \\
31.1 \\
31.3 \\
33.8 \\
35.7\end{array}$ & $\begin{array}{l}25,128 \\
24,910 \\
24,620 \\
24,387 \\
24,138\end{array}$ & $\begin{array}{l}7,848 \\
7,410 \\
7,504 \\
8,104 \\
8,376\end{array}$ & $\begin{array}{l}31.2 \\
29.7 \\
30.5 \\
33.2 \\
34.7\end{array}$ & $\begin{array}{l}10,701 \\
10,175 \\
10,041 \\
10,384 \\
10,059\end{array}$ & $\begin{array}{l}5,789 \\
5,473 \\
5,342 \\
5,666 \\
5,736\end{array}$ & $\begin{array}{l}54.1 \\
53.8 \\
53.2 \\
54.6 \\
57.0\end{array}$ & $\begin{array}{l}3,977 \\
3,714 \\
3,641 \\
3,501 \\
3,287\end{array}$ & $\begin{array}{l}1,471 \\
1,431 \\
1,264 \\
1,255 \\
1,338\end{array}$ & $\begin{array}{l}37.0 \\
38.5 \\
34.7 \\
35.8 \\
40.7\end{array}$ \\
\hline $\begin{array}{l}1982 \ldots \ldots \ldots \ldots \ldots \\
1981 \ldots \ldots \ldots \ldots \\
1980 \ldots \ldots \ldots \ldots \\
1979 \ldots \ldots \ldots \ldots \\
1978 \ldots \ldots \ldots \ldots\end{array}$ & \begin{tabular}{l|}
27,216 \\
26,834 \\
26,408 \\
25,944 \\
24,956
\end{tabular} & $\begin{array}{l}9,697 \\
9,173 \\
8,579 \\
8,050 \\
7,625\end{array}$ & $\begin{array}{l}35.6 \\
34.2 \\
32.5 \\
31.0 \\
30.6\end{array}$ & $\begin{array}{l}23,948 \\
23,423 \\
23,084 \\
22,666 \\
22,027\end{array}$ & $\begin{array}{l}8,355 \\
7,780 \\
7,190 \\
6,800 \\
6,493\end{array}$ & $\begin{array}{l}34.9 \\
33.2 \\
31.1 \\
30.0 \\
29.5\end{array}$ & $\begin{array}{l}9,699 \\
9,214 \\
9,338 \\
9,065 \\
8,689\end{array}$ & $\begin{array}{l}5,698 \\
5,222 \\
4,984 \\
4,816 \\
4,712\end{array}$ & $\begin{array}{l}58.8 \\
56.7 \\
53.4 \\
53.1 \\
54.2\end{array}$ & $\begin{array}{l}3,051 \\
3,277 \\
3,208 \\
3,127 \\
2,929\end{array}$ & $\begin{array}{l}1,229 \\
1,296 \\
1,314 \\
1,168 \\
1,132\end{array}$ & $\begin{array}{l}40.3 \\
39.6 \\
41.0 \\
37.3 \\
38.6\end{array}$ \\
\hline $\begin{array}{l}1977 \ldots \ldots \\
1976 \ldots \ldots \\
1975 \ldots \ldots \\
1974 \ldots \ldots \\
1973 \ldots \ldots\end{array}$ & \begin{tabular}{l|}
24,710 \\
24,399 \\
24,089 \\
23,699 \\
23,512
\end{tabular} & $\begin{array}{l}7,726 \\
7,595 \\
7,545 \\
7,182 \\
7,388\end{array}$ & $\begin{array}{l}31.3 \\
31.1 \\
31.3 \\
30.3 \\
31.4\end{array}$ & $\begin{array}{l}21,850 \\
21,840 \\
21,687 \\
21,341 \\
21,328\end{array}$ & $\begin{array}{l}6,667 \\
6,576 \\
6,533 \\
6,255 \\
6,560\end{array}$ & $\begin{array}{l}30.5 \\
30.1 \\
30.1 \\
29.3 \\
30.8\end{array}$ & $\begin{array}{l}8,315 \\
7,926 \\
7,679 \\
7,483 \\
7,188\end{array}$ & $\begin{array}{l}4,595 \\
4,415 \\
4,168 \\
4,116 \\
4,064\end{array}$ & $\begin{array}{l}55.3 \\
55.7 \\
54.3 \\
55.0 \\
56.5\end{array}$ & $\begin{array}{l}2,860 \\
2,559 \\
2,402 \\
2,359 \\
2,183\end{array}$ & $\begin{array}{r}1,059 \\
1,019 \\
1,011 \\
927 \\
828\end{array}$ & $\begin{array}{l}37.0 \\
39.8 \\
42.1 \\
39.3 \\
37.9\end{array}$ \\
\hline $\begin{array}{l}1972 \ldots \ldots \ldots \ldots \ldots \\
1971 \ldots \ldots \ldots \ldots \ldots \\
1970 \ldots \ldots \ldots \ldots \\
1969 \ldots \ldots \ldots \ldots \ldots \\
1968 \ldots \ldots \ldots \ldots\end{array}$ & $\begin{array}{l}23,144 \\
22,784 \\
22,515 \\
22,011 \\
21,944\end{array}$ & $\begin{array}{l}7,710 \\
7,396 \\
7,548 \\
7,095 \\
7,616\end{array}$ & $\begin{array}{l}33.3 \\
32.5 \\
33.5 \\
32.2 \\
34.7\end{array}$ & $\begin{array}{r}21,116 \\
20,900 \\
20,724 \\
20,192 \\
\text { (NA) }\end{array}$ & $\begin{array}{l}6,841 \\
6,530 \\
6,683 \\
6,245 \\
6,839\end{array}$ & $\begin{array}{l}32.4 \\
31.2 \\
32.2 \\
30.9 \\
33.7\end{array}$ & $\begin{array}{r}7,125 \\
6,398 \\
6,225 \\
5,537 \\
\text { (NA) }\end{array}$ & $\begin{array}{l}4,139 \\
3,587 \\
3,656 \\
3,225 \\
3,312\end{array}$ & $\begin{array}{l}58.1 \\
56.1 \\
58.7 \\
58.2 \\
58.9\end{array}$ & $\begin{array}{r}2,028 \\
1,884 \\
1,791 \\
1,819 \\
\text { (NA) }\end{array}$ & $\begin{array}{l}870 \\
866 \\
865 \\
850 \\
777\end{array}$ & $\begin{array}{l}42.9 \\
46.0 \\
48.3 \\
46.7 \\
46.3\end{array}$ \\
\hline $\begin{array}{l}1967 \ldots \\
1966 \ldots \\
1959 \ldots\end{array}$ & $\begin{array}{l}21,590 \\
21,206 \\
18,013\end{array}$ & $\begin{array}{l}8,486 \\
8,867 \\
9,927\end{array}$ & $\begin{array}{l}39.3 \\
41.8 \\
55.1\end{array}$ & $\begin{array}{l}\text { (NA) } \\
\text { (NA) } \\
\text { (NA) }\end{array}$ & $\begin{array}{l}7,677 \\
8,090 \\
9,112\end{array}$ & $\begin{array}{l}38.4 \\
40.9 \\
54.9\end{array}$ & $\begin{array}{l}\text { (NA) } \\
\text { (NA) } \\
\text { (NA) }\end{array}$ & $\begin{array}{l}3,362 \\
3,160 \\
2,416\end{array}$ & $\begin{array}{l}61.6 \\
65.3 \\
70.6\end{array}$ & $\begin{array}{r}(\mathrm{NA}) \\
(\mathrm{NA}) \\
1,430\end{array}$ & $\begin{array}{l}809 \\
777 \\
815\end{array}$ & $\begin{array}{l}49.3 \\
54.4 \\
57.0\end{array}$ \\
\hline
\end{tabular}


Table B-1.

Poverty Status of People by Family Relationship, Race, and Hispanic Origin: 1959 to 2005 -Con. (Numbers in thousands. People as of March of the following year)

\begin{tabular}{|c|c|c|c|c|c|c|c|c|c|c|c|c|}
\hline \multirow{4}{*}{$\begin{array}{l}\text { Race, Hispanic origin, } \\
\text { and year }\end{array}$} & \multicolumn{3}{|c|}{ All people } & \multicolumn{6}{|c|}{ People in families } & \multicolumn{3}{|c|}{ Unrelated individuals } \\
\hline & \multirow[b]{3}{*}{ Total } & \multicolumn{2}{|c|}{ Below poverty } & \multicolumn{3}{|c|}{ All families } & \multicolumn{3}{|c|}{$\begin{array}{l}\text { Families with female } \\
\text { householder, no } \\
\text { husband present }\end{array}$} & \multirow[b]{3}{*}{ Total } & \multicolumn{2}{|c|}{ Below poverty } \\
\hline & & \multirow[b]{2}{*}{ Number } & \multirow[b]{2}{*}{ Percent } & \multirow[b]{2}{*}{ Total } & \multicolumn{2}{|c|}{ Below poverty } & \multirow[b]{2}{*}{ Total } & \multicolumn{2}{|c|}{ Below poverty } & & \multirow[b]{2}{*}{ Number } & \multirow[b]{2}{*}{ Percent } \\
\hline & & & & & Number & Percent & & Number & Percent & & & \\
\hline \multicolumn{13}{|l|}{$\begin{array}{l}\text { ASIAN ALONE OR } \\
\text { IN COMBINATION }\end{array}$} \\
\hline $\begin{array}{l}2005 \ldots \ldots \ldots \ldots \\
2004^{1} \ldots \ldots \ldots \ldots \ldots \\
2003 \ldots \ldots \ldots \ldots \\
2002 \ldots \ldots \ldots \ldots\end{array}$ & $\begin{array}{l}13,731 \\
13,291 \\
12,891 \\
12,487\end{array}$ & $\begin{array}{l}1,501 \\
1,295 \\
1,527 \\
1,243\end{array}$ & $\begin{array}{r}10.9 \\
9.7 \\
11.8 \\
10.0\end{array}$ & $\begin{array}{l}11,931 \\
11,661 \\
11,266 \\
10,742\end{array}$ & $\begin{array}{r}1,039 \\
876 \\
1,116 \\
816\end{array}$ & $\begin{array}{l}8.7 \\
7.5 \\
9.9 \\
7.6\end{array}$ & $\begin{array}{l}1,223 \\
1,190 \\
1,184 \\
1,146\end{array}$ & $\begin{array}{l}220 \\
170 \\
294 \\
175\end{array}$ & $\begin{array}{l}18.0 \\
14.3 \\
24.8 \\
15.3\end{array}$ & $\begin{array}{l}1,771 \\
1,599 \\
1,590 \\
1,708\end{array}$ & $\begin{array}{l}457 \\
417 \\
402 \\
417\end{array}$ & $\begin{array}{l}25.8 \\
26.1 \\
25.3 \\
24.4\end{array}$ \\
\hline \multicolumn{13}{|l|}{ ASIAN ALONE ${ }^{10}$} \\
\hline $\begin{array}{l}2005 \ldots \ldots \ldots \ldots \\
2004^{1} \ldots \ldots \ldots \ldots \ldots \ldots \\
2003 \ldots \ldots \ldots \ldots \ldots \\
2002 \ldots \ldots \ldots \ldots \ldots\end{array}$ & $\begin{array}{l}12,580 \\
12,231 \\
11,856 \\
11,541\end{array}$ & $\begin{array}{l}1,402 \\
1,201 \\
1,401 \\
1,161\end{array}$ & $\begin{array}{r}11.1 \\
9.8 \\
11.8 \\
10.1\end{array}$ & $\begin{array}{r}10,911 \\
10,734 \\
10,333 \\
9,899\end{array}$ & $\begin{array}{r}970 \\
812 \\
1,017 \\
763\end{array}$ & $\begin{array}{l}8.9 \\
7.6 \\
9.8 \\
7.7\end{array}$ & $\begin{array}{l}1,059 \\
1,024 \\
1,028 \\
1,019\end{array}$ & $\begin{array}{l}189 \\
135 \\
242 \\
155\end{array}$ & $\begin{array}{l}17.8 \\
13.2 \\
23.6 \\
15.2\end{array}$ & $\begin{array}{l}1,645 \\
1,472 \\
1,494 \\
1,613\end{array}$ & $\begin{array}{l}427 \\
388 \\
375 \\
390\end{array}$ & $\begin{array}{l}26.0 \\
26.3 \\
25.1 \\
24.2\end{array}$ \\
\hline \multicolumn{13}{|l|}{$\begin{array}{l}\text { ASIAN AND PACIFIC } \\
\text { ISLANDER }^{8}\end{array}$} \\
\hline $\begin{array}{l}2001 \ldots \ldots \ldots \ldots \\
2000^{2} \ldots \ldots \ldots \ldots \\
1999^{3} \ldots \ldots \ldots \ldots \ldots \\
1998 \ldots \ldots \ldots \\
1997 \ldots \ldots \ldots \ldots\end{array}$ & $\begin{array}{l}12,465 \\
12,672 \\
11,955 \\
10,873 \\
10,482\end{array}$ & $\begin{array}{l}1,275 \\
1,258 \\
1,285 \\
1,360 \\
1,468\end{array}$ & \begin{tabular}{r|}
10.2 \\
9.9 \\
10.7 \\
12.5 \\
14.0
\end{tabular} & $\begin{array}{r}10,745 \\
11,044 \\
10,507 \\
9,576 \\
9,312\end{array}$ & $\begin{array}{r}873 \\
895 \\
1,010 \\
1,087 \\
1,116\end{array}$ & $\begin{array}{r}8.1 \\
8.1 \\
9.6 \\
11.4 \\
12.0\end{array}$ & $\begin{array}{r}1,333 \\
1,231 \\
1,201 \\
1,123 \\
932\end{array}$ & $\begin{array}{l}198 \\
289 \\
275 \\
373 \\
313\end{array}$ & $\begin{array}{l}14.8 \\
23.4 \\
22.9 \\
33.2 \\
33.6\end{array}$ & $\begin{array}{l}1,682 \\
1,588 \\
1,415 \\
1,266 \\
1,134\end{array}$ & $\begin{array}{l}393 \\
350 \\
270 \\
257 \\
327\end{array}$ & $\begin{array}{l}23.4 \\
22.0 \\
19.1 \\
20.3 \\
28.9\end{array}$ \\
\hline $\begin{array}{l}1996 \ldots \ldots \\
1995 \ldots \ldots \\
1994 \ldots \ldots \\
1993 \ldots \ldots \\
1992 \ldots \ldots\end{array}$ & $\begin{array}{r}10,054 \\
9,644 \\
6,654 \\
7,434 \\
7,779\end{array}$ & $\begin{array}{r}1,454 \\
1,411 \\
974 \\
1,134 \\
985\end{array}$ & $\begin{array}{l}14.5 \\
14.6 \\
14.6 \\
15.3 \\
12.7\end{array}$ & $\begin{array}{l}8,900 \\
8,582 \\
5,915 \\
6,609 \\
6,922\end{array}$ & $\begin{array}{r}1,172 \\
1,112 \\
776 \\
898 \\
787\end{array}$ & $\begin{array}{l}13.2 \\
13.0 \\
13.1 \\
13.6 \\
11.4\end{array}$ & $\begin{array}{r}1,018 \\
919 \\
582 \\
725 \\
729\end{array}$ & $\begin{array}{l}300 \\
266 \\
137 \\
126 \\
183\end{array}$ & \begin{tabular}{l|l|}
29.5 \\
28.9 \\
23.6 \\
17.4 \\
25.0
\end{tabular} & $\begin{array}{r}1,120 \\
1,013 \\
696 \\
791 \\
828\end{array}$ & $\begin{array}{l}255 \\
260 \\
179 \\
228 \\
193\end{array}$ & $\begin{array}{l}22.8 \\
25.6 \\
25.7 \\
28.8 \\
23.3\end{array}$ \\
\hline $\begin{array}{l}1991^{5} \ldots \\
1990 \ldots \\
1989 \ldots \\
1988^{6} \ldots \\
1987^{6} \ldots\end{array}$ & $\begin{array}{l}7,192 \\
7,014 \\
6,673 \\
6,447 \\
6,322\end{array}$ & $\begin{array}{r}996 \\
858 \\
939 \\
1,117 \\
1,021\end{array}$ & \begin{tabular}{l|}
13.8 \\
12.2 \\
14.1 \\
17.3 \\
16.1
\end{tabular} & $\begin{array}{l}6,367 \\
6,300 \\
5,917 \\
5,767 \\
5,785\end{array}$ & $\begin{array}{l}773 \\
712 \\
779 \\
942 \\
875\end{array}$ & $\begin{array}{l}12.1 \\
11.3 \\
13.2 \\
16.3 \\
15.1\end{array}$ & $\begin{array}{l}721 \\
638 \\
614 \\
650 \\
584\end{array}$ & $\begin{array}{l}177 \\
132 \\
212 \\
263 \\
187\end{array}$ & \begin{tabular}{l|l|}
24.6 \\
20.7 \\
34.6 \\
40.5 \\
32.0
\end{tabular} & $\begin{array}{l}785 \\
668 \\
712 \\
651 \\
516\end{array}$ & $\begin{array}{l}209 \\
124 \\
144 \\
160 \\
138\end{array}$ & $\begin{array}{l}26.6 \\
18.5 \\
20.2 \\
24.5 \\
26.8\end{array}$ \\
\hline
\end{tabular}


Table B-1.

Poverty Status of People by Family Relationship, Race, and Hispanic Origin: 1959 to 2005 -Con. (Numbers in thousands. People as of March of the following year)

\begin{tabular}{|c|c|c|c|c|c|c|c|c|c|c|c|c|}
\hline \multirow{4}{*}{$\begin{array}{c}\text { Race, Hispanic origin, } \\
\text { and year }\end{array}$} & \multicolumn{3}{|c|}{ All people } & \multicolumn{6}{|c|}{ People in families } & \multicolumn{3}{|c|}{ Unrelated individuals } \\
\hline & \multirow[b]{3}{*}{ Total } & \multicolumn{2}{|c|}{ Below poverty } & \multicolumn{3}{|c|}{ All families } & \multicolumn{3}{|c|}{$\begin{array}{l}\text { Families with female } \\
\text { householder, no } \\
\text { husband present }\end{array}$} & \multirow[b]{3}{*}{ Total } & \multicolumn{2}{|c|}{ Below poverty } \\
\hline & & \multirow[b]{2}{*}{ Jumber } & \multirow[b]{2}{*}{ Percent } & \multirow[b]{2}{*}{ Total } & \multicolumn{2}{|c|}{ Below poverty } & \multirow[b]{2}{*}{ Total } & \multicolumn{2}{|c|}{ Below poverty } & & \multirow[b]{2}{*}{ Number } & \multirow[b]{2}{*}{ Percent } \\
\hline & & & & & Number & Percent & & Number & Percent & & & \\
\hline \multicolumn{13}{|l|}{$\begin{array}{l}\text { HISPANIC } \\
\text { (ANY RACE) }\end{array}$} \\
\hline $\begin{array}{l}2005 \ldots \ldots \ldots \\
2004^{1} \ldots \ldots \ldots\end{array}$ & $\begin{array}{l}43,020 \\
41,690\end{array}$ & $\begin{array}{l}9,368 \\
9,122\end{array}$ & $\begin{array}{l}21.8 \\
21.9\end{array}$ & $\begin{array}{l}37,759 \\
36,438\end{array}$ & $\begin{array}{l}7,767 \\
7,705\end{array}$ & $\begin{array}{l}20.6 \\
21.1\end{array}$ & $\begin{array}{l}7,868 \\
7,825\end{array}$ & $\begin{array}{l}3,069 \\
3,072\end{array}$ & $\begin{array}{l}39.0 \\
39.3\end{array}$ & $\begin{array}{l}4,971 \\
4,971\end{array}$ & $\begin{array}{l}1,451 \\
1,293\end{array}$ & $\begin{array}{l}29.2 \\
26.0\end{array}$ \\
\hline $\begin{array}{l}2003 \ldots \\
2002 \ldots \\
2001 \ldots \\
2000^{2} \ldots \\
1999^{3} \ldots\end{array}$ & $\begin{array}{l}40,300 \\
39,216 \\
37,312 \\
35,955 \\
34,632\end{array}$ & $\begin{array}{l}9,051 \\
8,555 \\
7,997 \\
7,747 \\
7,876\end{array}$ & $\begin{array}{l}22.5 \\
21.8 \\
21.4 \\
21.5 \\
22.7\end{array}$ & $\begin{array}{l}35,469 \\
34,598 \\
33,110 \\
31,700 \\
30,872\end{array}$ & $\begin{array}{l}7,637 \\
7,184 \\
6,674 \\
6,430 \\
6,702\end{array}$ & $\begin{array}{l}21.5 \\
20.8 \\
20.2 \\
20.3 \\
21.7\end{array}$ & $\begin{array}{l}7,452 \\
7,013 \\
6,830 \\
6,469 \\
6,527\end{array}$ & $\begin{array}{l}2,861 \\
2,554 \\
2,585 \\
2,444 \\
2,642\end{array}$ & $\begin{array}{l}38.4 \\
36.4 \\
37.8 \\
37.8 \\
40.5\end{array}$ & $\begin{array}{l}4,620 \\
4,364 \\
3,981 \\
3,978 \\
3,481\end{array}$ & $\begin{array}{l}1,325 \\
1,255 \\
1,211 \\
1,163 \\
1,068\end{array}$ & $\begin{array}{l}28.7 \\
28.8 \\
30.4 \\
29.2 \\
30.7\end{array}$ \\
\hline $\begin{array}{l}1998 \ldots \ldots \ldots \ldots \ldots \\
1997 \ldots \ldots \ldots \ldots \ldots \\
1996 \ldots \ldots \ldots \ldots \ldots \\
1995 \ldots \ldots \ldots \ldots \\
1994 \ldots \ldots \ldots \ldots \ldots\end{array}$ & $\begin{array}{l}31,515 \\
30,637 \\
29,614 \\
28,344 \\
27,442\end{array}$ & $\begin{array}{l}8,070 \\
8,308 \\
8,697 \\
8,574 \\
8,416\end{array}$ & $\begin{array}{l}25.6 \\
27.1 \\
29.4 \\
30.3 \\
30.7\end{array}$ & $\begin{array}{l}28,055 \\
27,467 \\
26,340 \\
25,165 \\
24,390\end{array}$ & $\begin{array}{l}6,814 \\
7,198 \\
7,515 \\
7,341 \\
7,357\end{array}$ & $\begin{array}{l}24.3 \\
26.2 \\
28.5 \\
29.2 \\
30.2\end{array}$ & $\begin{array}{l}6,074 \\
5,718 \\
5,641 \\
5,785 \\
5,328\end{array}$ & $\begin{array}{l}2,837 \\
2,911 \\
3,020 \\
3,053 \\
2,920\end{array}$ & $\begin{array}{l}46.7 \\
50.9 \\
53.5 \\
52.8 \\
54.8\end{array}$ & $\begin{array}{l}3,218 \\
2,976 \\
2,985 \\
2,947 \\
2,798\end{array}$ & $\begin{array}{r}1,097 \\
1,017 \\
1,066 \\
1,092 \\
926\end{array}$ & $\begin{array}{l}34.1 \\
34.2 \\
35.7 \\
37.0 \\
33.1\end{array}$ \\
\hline $\begin{array}{l}1993 \ldots \ldots \ldots \\
1992^{4} \ldots \ldots \ldots \\
1991^{5} \ldots \ldots \ldots \\
1990 \ldots \ldots \ldots \\
1989 \ldots \ldots \ldots\end{array}$ & $\begin{array}{l}26,559 \\
25,646 \\
22,070 \\
21,405 \\
20,746\end{array}$ & $\begin{array}{l}8,126 \\
7,592 \\
6,339 \\
6,006 \\
5,430\end{array}$ & $\begin{array}{l}30.6 \\
29.6 \\
28.7 \\
28.1 \\
26.2\end{array}$ & $\begin{array}{l}23,439 \\
22,695 \\
19,658 \\
18,912 \\
18,488\end{array}$ & $\begin{array}{l}6,876 \\
6,455 \\
5,541 \\
5,091 \\
4,659\end{array}$ & $\begin{array}{l}29.3 \\
28.4 \\
28.2 \\
26.9 \\
25.2\end{array}$ & $\begin{array}{l}5,333 \\
4,806 \\
4,326 \\
3,993 \\
3,763\end{array}$ & $\begin{array}{l}2,837 \\
2,474 \\
2,282 \\
2,115 \\
1,902\end{array}$ & $\begin{array}{l}53.2 \\
51.5 \\
52.7 \\
53.0 \\
50.6\end{array}$ & $\begin{array}{l}2,717 \\
2,577 \\
2,146 \\
2,254 \\
2,045\end{array}$ & $\begin{array}{l}972 \\
881 \\
667 \\
774 \\
634\end{array}$ & $\begin{array}{l}35.8 \\
34.2 \\
31.1 \\
34.3 \\
31.0\end{array}$ \\
\hline $\begin{array}{l}1988^{6} \ldots \ldots \ldots \ldots \ldots \\
1987^{6} \ldots \ldots \ldots \ldots \ldots \\
1986 \ldots \ldots \ldots \ldots \\
1985 \ldots \ldots \ldots \ldots \\
1984 \ldots \ldots \ldots \ldots\end{array}$ & $\begin{array}{l}20,064 \\
19,395 \\
18,758 \\
18,075 \\
16,916\end{array}$ & $\begin{array}{l}5,357 \\
5,422 \\
5,117 \\
5,236 \\
4,806\end{array}$ & $\begin{array}{l}26.7 \\
28.0 \\
27.3 \\
29.0 \\
28.4\end{array}$ & $\begin{array}{l}18,102 \\
17,342 \\
16,880 \\
16,276 \\
15,293\end{array}$ & $\begin{array}{l}4,700 \\
4,761 \\
4,469 \\
4,605 \\
4,192\end{array}$ & $\begin{array}{l}26.0 \\
27.5 \\
26.5 \\
28.3 \\
27.4\end{array}$ & $\begin{array}{l}3,734 \\
3,678 \\
3,631 \\
3,561 \\
3,139\end{array}$ & $\begin{array}{l}2,052 \\
2,045 \\
1,921 \\
1,983 \\
1,764\end{array}$ & $\begin{array}{l}55.0 \\
55.6 \\
52.9 \\
55.7 \\
56.2\end{array}$ & $\begin{array}{l}1,864 \\
1,933 \\
1,685 \\
1,602 \\
1,481\end{array}$ & $\begin{array}{l}597 \\
598 \\
553 \\
532 \\
545\end{array}$ & $\begin{array}{l}32.0 \\
31.0 \\
32.8 \\
33.2 \\
36.8\end{array}$ \\
\hline $\begin{array}{l}1983 \ldots \ldots \ldots \ldots \ldots \\
1982 \ldots \ldots \ldots \ldots \\
1981 \ldots \ldots \ldots \ldots \\
1980 \ldots \ldots \ldots \\
1979 \ldots \ldots \ldots \ldots \ldots\end{array}$ & $\begin{array}{l}16,544 \\
14,385 \\
14,021 \\
13,600 \\
13,371\end{array}$ & $\begin{array}{l}4,633 \\
4,301 \\
3,713 \\
3,491 \\
2,921\end{array}$ & $\begin{array}{l}28.0 \\
29.9 \\
26.5 \\
25.7 \\
21.8\end{array}$ & $\begin{array}{l}15,075 \\
13,242 \\
12,922 \\
12,547 \\
12,291\end{array}$ & $\begin{array}{l}4,113 \\
3,865 \\
3,349 \\
3,143 \\
2,599\end{array}$ & $\begin{array}{l}27.3 \\
29.2 \\
25.9 \\
25.1 \\
21.1\end{array}$ & $\begin{array}{l}3,032 \\
2,664 \\
2,622 \\
2,421 \\
2,058\end{array}$ & $\begin{array}{l}1,670 \\
1,601 \\
1,465 \\
1,319 \\
1,053\end{array}$ & $\begin{array}{l}55.1 \\
60.1 \\
55.9 \\
54.5 \\
51.2\end{array}$ & $\begin{array}{r}1,364 \\
1,018 \\
1,005 \\
970 \\
991\end{array}$ & $\begin{array}{l}457 \\
358 \\
313 \\
312 \\
286\end{array}$ & $\begin{array}{l}33.5 \\
35.1 \\
31.1 \\
32.2 \\
28.8\end{array}$ \\
\hline 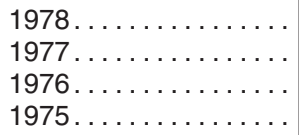 & $\begin{array}{l}12,079 \\
12,046 \\
11,269 \\
11,117\end{array}$ & $\begin{array}{l}2,607 \\
2,700 \\
2,783 \\
2,991\end{array}$ & $\begin{array}{l}21.6 \\
22.4 \\
24.7 \\
26.9\end{array}$ & $\begin{array}{l}11,193 \\
11,249 \\
10,552 \\
10,472\end{array}$ & $\begin{array}{l}2,343 \\
2,463 \\
2,516 \\
2,755\end{array}$ & $\begin{array}{l}20.9 \\
21.9 \\
23.8 \\
26.3\end{array}$ & $\begin{array}{l}1,817 \\
1,901 \\
1,766 \\
1,842\end{array}$ & $\begin{array}{l}1,024 \\
1,077 \\
1,000 \\
1,053\end{array}$ & $\begin{array}{l}56.4 \\
56.7 \\
56.6 \\
57.2\end{array}$ & $\begin{array}{l}886 \\
797 \\
716 \\
645\end{array}$ & $\begin{array}{l}264 \\
237 \\
266 \\
236\end{array}$ & $\begin{array}{l}29.8 \\
29.8 \\
37.2 \\
36.6\end{array}$ \\
\hline $\begin{array}{l}1974 \ldots \ldots \ldots \ldots \ldots \\
1973 \ldots \ldots \ldots \ldots \\
1972 \ldots \ldots \ldots \ldots\end{array}$ & $\begin{array}{l}11,201 \\
10,795 \\
10,588\end{array}$ & $\begin{array}{l}2,575 \\
2,366 \\
2,414\end{array}$ & $\begin{array}{l}23.0 \\
21.9 \\
22.8\end{array}$ & $\begin{array}{l}10,584 \\
10,269 \\
10,099\end{array}$ & $\begin{array}{l}2,374 \\
2,209 \\
2,252\end{array}$ & $\begin{array}{l}22.4 \\
21.5 \\
22.3\end{array}$ & $\begin{array}{l}1,723 \\
1,534 \\
1,370\end{array}$ & $\begin{array}{l}915 \\
881 \\
733\end{array}$ & $\begin{array}{l}53.1 \\
57.4 \\
53.5\end{array}$ & $\begin{array}{l}617 \\
526 \\
488\end{array}$ & $\begin{array}{l}201 \\
157 \\
162\end{array}$ & $\begin{array}{l}32.6 \\
29.9 \\
33.2\end{array}$ \\
\hline
\end{tabular}

\section{(NA) Not available.}

1 For 2004, figures are revised to reflect a correction to the weights in the 2005 ASEC.

2 Consistent with 2001 data through implementation of Census 2000-based population controls and a 28,000 household sample expansion.

${ }^{3}$ For 1999, figures are based on Census 2000 population controls.

${ }^{4}$ For 1992, figures are based on 1990 census population controls.

5 For 1991, figures are revised to correct for nine omitted weights from the original March 1992 CPS file.

${ }^{6}$ For 1988 and 1987, figures are based on new processing procedures and are also revised to reflect corrections to the files after publication of the 1988 advance report Money Income and Poverty Status in the United States: 1988, P-60, No. 166.

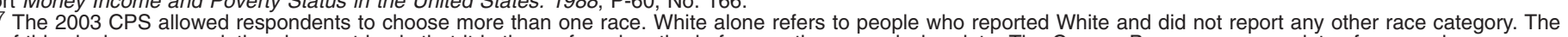
use of this single-race population does not imply that it is the preferred method of presenting or analyzing data. The Census Bureau uses a variety of approaches.

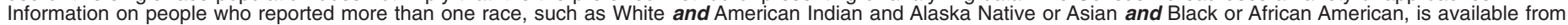
Census 2000 through American FactFinder. About 2.6 percent of people reported more than one race in Census 2000.

${ }^{8}$ For 2001 and earlier years, the CPS allowed respondents to report only one race group. The reference race groups for 2001 and earlier poverty data are White, non-Hispanic White, Black, and Asian and Pacific Islander.

${ }_{10}$ Black alone refers to people who reported Black and did not report any other race.

${ }^{10}$ Asian alone refers to people who reported Asian and did not report any other race.

Note: Prior to 1979, people in unrelated subfamilies were included in people in families. Beginning in 1979, people in unrelated subfamilies are included in all people but are excluded from people in families.

Source: U.S. Census Bureau, Current Population Survey, 1960 to 2006 Annual Social and Economic Supplements. 
Table B-2.

Poverty Status of People by Age, Race, and Hispanic Origin: 1959 to 2005

(Numbers in thousands. People as of March of the following year)

\begin{tabular}{|c|c|c|c|c|c|c|c|c|c|c|c|c|}
\hline \multirow{4}{*}{$\begin{array}{l}\text { Race, Hispanic } \\
\text { origin, and year }\end{array}$} & \multicolumn{6}{|c|}{ Under 18 years } & \multicolumn{3}{|c|}{18 to 64 years } & \multicolumn{3}{|c|}{65 years and older } \\
\hline & \multicolumn{3}{|c|}{ All people } & \multicolumn{3}{|c|}{ Related children in families } & \multirow[b]{3}{*}{ Total } & \multirow{2}{*}{\multicolumn{2}{|c|}{ Below poverty }} & \multirow[b]{3}{*}{ Total } & \multirow{2}{*}{\multicolumn{2}{|c|}{ Below poverty }} \\
\hline & \multirow[b]{2}{*}{ Total } & \multicolumn{2}{|c|}{ Below poverty } & \multirow[b]{2}{*}{ Total } & \multicolumn{2}{|c|}{ Below poverty } & & & & & & \\
\hline & & Number & Percent & & Number & Percent & & Number & Percent & & Number & Percent \\
\hline \multicolumn{13}{|l|}{ ALL RACES } \\
\hline $\begin{array}{l}2005 \ldots \\
2004^{1} \ldots\end{array}$ & $\begin{array}{l}73,285 \\
73,241\end{array}$ & $\begin{array}{l}12,896 \\
13,041\end{array}$ & $\begin{array}{l}17.6 \\
17.8\end{array}$ & $\begin{array}{l}72,095 \\
72,133\end{array}$ & $\begin{array}{l}12,335 \\
12,473\end{array}$ & $\begin{array}{l}17.1 \\
17.3\end{array}$ & $\begin{array}{l}184,345 \\
182,166\end{array}$ & $\begin{array}{l}20,450 \\
20,545\end{array}$ & $\begin{array}{l}11.1 \\
11.3\end{array}$ & $\begin{array}{l}35,505 \\
35,209\end{array}$ & $\begin{array}{l}3,603 \\
3,453\end{array}$ & $\begin{array}{r}10.1 \\
9.8\end{array}$ \\
\hline $\begin{array}{l}2003 \ldots \ldots \ldots \ldots \\
2002 \ldots \ldots \ldots \ldots \\
2001 \ldots \ldots \ldots \ldots \\
2000^{2} \ldots \ldots \ldots \ldots \\
1999^{3} \ldots \ldots \ldots \ldots\end{array}$ & $\begin{array}{l}72,999 \\
72,696 \\
72,021 \\
71,741 \\
71,685\end{array}$ & $\begin{array}{l}12,866 \\
12,133 \\
11,733 \\
11,587 \\
12,280\end{array}$ & $\begin{array}{l}17.6 \\
16.7 \\
16.3 \\
16.2 \\
17.1\end{array}$ & $\begin{array}{l}71,907 \\
71,619 \\
70,950 \\
70,538 \\
70,424\end{array}$ & $\begin{array}{l}12,340 \\
11,646 \\
11,175 \\
11,005 \\
11,678\end{array}$ & $\begin{array}{l}17.2 \\
16.3 \\
15.8 \\
15.6 \\
16.6\end{array}$ & $\begin{array}{l}180,041 \\
178,388 \\
175,685 \\
173,638 \\
171,146\end{array}$ & $\begin{array}{l}19,443 \\
18,861 \\
17,760 \\
16,671 \\
17,289\end{array}$ & $\begin{array}{r}10.8 \\
10.6 \\
10.1 \\
9.6 \\
10.1\end{array}$ & $\begin{array}{l}34,659 \\
34,234 \\
33,769 \\
33,566 \\
33,377\end{array}$ & $\begin{array}{l}3,552 \\
3,576 \\
3,414 \\
3,323 \\
3,222\end{array}$ & $\begin{array}{r}10.2 \\
10.4 \\
10.1 \\
9.9 \\
9.7\end{array}$ \\
\hline $\begin{array}{l}1998 \ldots \ldots \ldots \ldots \ldots \\
1997 \ldots \ldots \ldots \ldots \ldots \\
1996 \ldots \ldots \ldots \ldots \ldots \\
1995 \ldots \ldots \ldots \ldots \ldots \ldots \\
1994 \ldots \ldots \ldots \ldots \ldots\end{array}$ & $\begin{array}{l}71,338 \\
71,069 \\
70,650 \\
70,566 \\
70,020\end{array}$ & $\begin{array}{l}13,467 \\
14,113 \\
14,463 \\
14,665 \\
15,289\end{array}$ & $\begin{array}{l}18.9 \\
19.9 \\
20.5 \\
20.8 \\
21.8\end{array}$ & $\begin{array}{l}70,253 \\
69,844 \\
69,411 \\
69,425 \\
68,819\end{array}$ & $\begin{array}{l}12,845 \\
13,422 \\
13,764 \\
13,999 \\
14,610\end{array}$ & $\begin{array}{l}18.3 \\
19.2 \\
19.8 \\
20.2 \\
21.2\end{array}$ & $\begin{array}{l}167,327 \\
165,329 \\
163,691 \\
161,508 \\
160,329\end{array}$ & $\begin{array}{l}17,623 \\
18,085 \\
18,638 \\
18,442 \\
19,107\end{array}$ & $\begin{array}{l}10.5 \\
10.9 \\
11.4 \\
11.4 \\
11.9\end{array}$ & $\begin{array}{l}32,394 \\
32,082 \\
31,877 \\
31,658 \\
31,267\end{array}$ & $\begin{array}{l}3,386 \\
3,376 \\
3,428 \\
3,318 \\
3,663\end{array}$ & $\begin{array}{l}10.5 \\
10.5 \\
10.8 \\
10.5 \\
11.7\end{array}$ \\
\hline $\begin{array}{l}1993 \ldots \ldots \ldots \ldots \ldots \\
1992^{4} \ldots \ldots \ldots \ldots \ldots \\
1991^{5} \ldots \ldots \ldots \ldots \ldots \\
1990 \ldots \ldots \ldots \ldots \ldots \\
1989 \ldots \ldots \ldots \ldots \ldots\end{array}$ & $\begin{array}{l}69,292 \\
68,440 \\
65,918 \\
65,049 \\
64,144\end{array}$ & $\begin{array}{l}15,727 \\
15,294 \\
14,341 \\
13,431 \\
12,590\end{array}$ & $\begin{array}{l}22.7 \\
22.3 \\
21.8 \\
20.6 \\
19.6\end{array}$ & $\begin{array}{l}68,040 \\
67,256 \\
64,800 \\
63,908 \\
63,225\end{array}$ & $\begin{array}{l}14,961 \\
14,521 \\
13,658 \\
12,715 \\
12,001\end{array}$ & $\begin{array}{l}22.0 \\
21.6 \\
21.1 \\
19.9 \\
19.0\end{array}$ & $\begin{array}{l}159,208 \\
157,680 \\
154,684 \\
153,502 \\
152,282\end{array}$ & $\begin{array}{l}19,781 \\
18,793 \\
17,586 \\
16,496 \\
15,575\end{array}$ & $\begin{array}{l}12.4 \\
11.9 \\
11.4 \\
10.7 \\
10.2\end{array}$ & $\begin{array}{l}30,779 \\
30,430 \\
30,590 \\
30,093 \\
29,566\end{array}$ & $\begin{array}{l}3,755 \\
3,928 \\
3,781 \\
3,658 \\
3,363\end{array}$ & $\begin{array}{l}12.2 \\
12.9 \\
12.4 \\
12.2 \\
11.4\end{array}$ \\
\hline 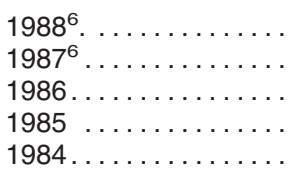 & $\begin{array}{l}63,747 \\
63,294 \\
62,948 \\
62,876 \\
62,447\end{array}$ & $\begin{array}{l}12,455 \\
12,843 \\
12,876 \\
13,010 \\
13,420\end{array}$ & $\begin{array}{l}19.5 \\
20.3 \\
20.5 \\
20.7 \\
21.5\end{array}$ & $\begin{array}{l}62,906 \\
62,423 \\
62,009 \\
62,019 \\
61,681\end{array}$ & $\begin{array}{l}11,935 \\
12,275 \\
12,257 \\
12,483 \\
12,929\end{array}$ & $\begin{array}{l}19.0 \\
19.7 \\
19.8 \\
20.1 \\
21.0\end{array}$ & $\begin{array}{l}150,761 \\
149,201 \\
147,631 \\
146,396 \\
144,551\end{array}$ & $\begin{array}{l}15,809 \\
15,815 \\
16,017 \\
16,598 \\
16,952\end{array}$ & $\begin{array}{l}10.5 \\
10.6 \\
10.8 \\
11.3 \\
11.7\end{array}$ & $\begin{array}{l}29,022 \\
28,487 \\
27,975 \\
27,322 \\
26,818\end{array}$ & $\begin{array}{l}3,481 \\
3,563 \\
3,477 \\
3,456 \\
3,330\end{array}$ & $\begin{array}{l}12.0 \\
12.5 \\
12.4 \\
12.6 \\
12.4\end{array}$ \\
\hline $\begin{array}{l}1983 \ldots \ldots \ldots \ldots \ldots \\
1982 \ldots \ldots \ldots \ldots \ldots \\
1981 \ldots \ldots \ldots \ldots \\
1980 \ldots \ldots \ldots \ldots \\
1979 \ldots \ldots \ldots \ldots\end{array}$ & $\begin{array}{l}62,334 \\
62,345 \\
62,449 \\
62,914 \\
63,375\end{array}$ & $\begin{array}{l}13,911 \\
13,647 \\
12,505 \\
11,543 \\
10,377\end{array}$ & $\begin{array}{l}22.3 \\
21.9 \\
20.0 \\
18.3 \\
16.4\end{array}$ & $\begin{array}{l}61,578 \\
61,565 \\
61,756 \\
62,168 \\
62,646\end{array}$ & $\begin{array}{r}13,427 \\
13,139 \\
12,068 \\
11,114 \\
9,993\end{array}$ & $\begin{array}{l}21.8 \\
21.3 \\
19.5 \\
17.9 \\
16.0\end{array}$ & $\begin{array}{l}143,052 \\
141,328 \\
139,477 \\
137,428 \\
135,333\end{array}$ & $\begin{array}{l}17,767 \\
17,000 \\
15,464 \\
13,858 \\
12,014\end{array}$ & $\begin{array}{r}12.4 \\
12.0 \\
11.1 \\
10.1 \\
8.9\end{array}$ & $\begin{array}{l}26,313 \\
25,738 \\
25,231 \\
24,686 \\
24,194\end{array}$ & $\begin{array}{l}3,625 \\
3,751 \\
3,853 \\
3,871 \\
3,682\end{array}$ & $\begin{array}{l}13.8 \\
14.6 \\
15.3 \\
15.7 \\
15.2\end{array}$ \\
\hline $\begin{array}{l}1978 \ldots \ldots \ldots \ldots \ldots \\
1977 \ldots \ldots \ldots \ldots \ldots \\
1976 \ldots \ldots \ldots \ldots \\
1975 \ldots \ldots \ldots \ldots \ldots \\
1974 \ldots \ldots \ldots \ldots \ldots\end{array}$ & $\begin{array}{l}62,311 \\
63,137 \\
64,028 \\
65,079 \\
66,134\end{array}$ & $\begin{array}{r}9,931 \\
10,288 \\
10,273 \\
11,104 \\
10,156\end{array}$ & $\begin{array}{l}15.9 \\
16.2 \\
16.0 \\
17.1 \\
15.4\end{array}$ & $\begin{array}{l}61,987 \\
62,823 \\
63,729 \\
64,750 \\
65,802\end{array}$ & $\begin{array}{r}9,722 \\
10,028 \\
10,081 \\
10,882 \\
9,967\end{array}$ & $\begin{array}{l}15.7 \\
16.0 \\
15.8 \\
16.8 \\
15.1\end{array}$ & $\begin{array}{l}130,169 \\
128,262 \\
126,175 \\
124,122 \\
122,101\end{array}$ & $\begin{array}{r}11,332 \\
11,316 \\
11,389 \\
11,456 \\
10,132\end{array}$ & $\begin{array}{l}8.7 \\
8.8 \\
9.0 \\
9.2 \\
8.3\end{array}$ & $\begin{array}{l}23,175 \\
22,468 \\
22,100 \\
21,662 \\
21,127\end{array}$ & $\begin{array}{l}3,233 \\
3,177 \\
3,313 \\
3,317 \\
3,085\end{array}$ & $\begin{array}{l}14.0 \\
14.1 \\
15.0 \\
15.3 \\
14.6\end{array}$ \\
\hline $\begin{array}{l}1973 \ldots \ldots \ldots \ldots \ldots \\
1972 \ldots \ldots \ldots \ldots \ldots \\
1971 \ldots \ldots \ldots \ldots \\
1970 \ldots \ldots \ldots \ldots \ldots \\
1969 \ldots \ldots \ldots \ldots \ldots\end{array}$ & $\begin{array}{l}66,959 \\
67,930 \\
68,816 \\
69,159 \\
69,090\end{array}$ & $\begin{array}{r}9,642 \\
10,284 \\
10,551 \\
10,440 \\
9,691\end{array}$ & $\begin{array}{l}14.4 \\
15.1 \\
15.3 \\
15.1 \\
14.0\end{array}$ & $\begin{array}{l}66,626 \\
67,592 \\
68,474 \\
68,815 \\
68,746\end{array}$ & $\begin{array}{r}9,453 \\
10,082 \\
10,344 \\
10,235 \\
9,501\end{array}$ & $\begin{array}{l}14.2 \\
14.9 \\
15.1 \\
14.9 \\
13.8\end{array}$ & $\begin{array}{l}120,060 \\
117,957 \\
115,911 \\
113,554 \\
111,528\end{array}$ & $\begin{array}{r}9,977 \\
10,438 \\
10,735 \\
10,187 \\
9,669\end{array}$ & $\begin{array}{l}8.3 \\
8.8 \\
9.3 \\
9.0 \\
8.7\end{array}$ & $\begin{array}{l}20,602 \\
20,117 \\
19,827 \\
19,470 \\
18,899\end{array}$ & $\begin{array}{l}3,354 \\
3,738 \\
4,273 \\
4,793 \\
4,787\end{array}$ & $\begin{array}{l}16.3 \\
18.6 \\
21.6 \\
24.6 \\
25.3\end{array}$ \\
\hline $\begin{array}{l}1968 \ldots \ldots \ldots \ldots \ldots \\
1967 \ldots \ldots \ldots \ldots \ldots \\
1966 \ldots \ldots \ldots \ldots \\
1965 \ldots \ldots \ldots \ldots \ldots \\
1964 \ldots \ldots \ldots \ldots \ldots\end{array}$ & $\begin{array}{l}70,385 \\
70,408 \\
70,218 \\
69,986 \\
69,711\end{array}$ & $\begin{array}{l}10,954 \\
11,656 \\
12,389 \\
14,676 \\
16,051\end{array}$ & $\begin{array}{l}15.6 \\
16.6 \\
17.6 \\
21.0 \\
23.0\end{array}$ & $\begin{array}{l}70,035 \\
70,058 \\
69,869 \\
69,638 \\
69,364\end{array}$ & $\begin{array}{l}10,739 \\
11,427 \\
12,146 \\
14,388 \\
15,736\end{array}$ & $\begin{array}{l}15.3 \\
16.3 \\
17.4 \\
20.7 \\
22.7\end{array}$ & $\begin{array}{r}108,684 \\
107,024 \\
105,241 \\
(\mathrm{NA}) \\
(\mathrm{NA})\end{array}$ & $\begin{array}{r}9,803 \\
10,725 \\
11,007 \\
(\mathrm{NA}) \\
(\mathrm{NA})\end{array}$ & $\begin{array}{r}9.0 \\
10.0 \\
10.5 \\
(\mathrm{NA}) \\
(\mathrm{NA})\end{array}$ & $\begin{array}{r}18,559 \\
18,240 \\
17,929 \\
(\mathrm{NA}) \\
(\mathrm{NA})\end{array}$ & $\begin{array}{r}4,632 \\
5,388 \\
5,114 \\
\text { (NA) } \\
\text { (NA) }\end{array}$ & $\begin{array}{l}25.0 \\
29.5 \\
28.5 \\
\text { (NA) } \\
\text { (NA) }\end{array}$ \\
\hline $\begin{array}{l}1963 \ldots \ldots \ldots \ldots \ldots \\
1962 \ldots \ldots \ldots \ldots \ldots \\
1961 \ldots \ldots \ldots \ldots \\
1960 \ldots \ldots \ldots \ldots \\
1959 \ldots \ldots \ldots \ldots\end{array}$ & $\begin{array}{l}69,181 \\
67,722 \\
66,121 \\
65,601 \\
64,315\end{array}$ & $\begin{array}{l}16,005 \\
16,963 \\
16,909 \\
17,634 \\
17,552\end{array}$ & $\begin{array}{l}23.1 \\
25.0 \\
25.6 \\
26.9 \\
27.3\end{array}$ & $\begin{array}{l}68,837 \\
67,385 \\
65,792 \\
65,275 \\
63,995\end{array}$ & $\begin{array}{l}15,691 \\
16,630 \\
16,577 \\
17,288 \\
17,208\end{array}$ & $\begin{array}{l}22.8 \\
24.7 \\
25.2 \\
26.5 \\
26.9\end{array}$ & $\begin{array}{r}(\mathrm{NA}) \\
(\mathrm{NA}) \\
(\mathrm{NA}) \\
(\mathrm{NA}) \\
96,685\end{array}$ & $\begin{array}{r}(\mathrm{NA}) \\
(\mathrm{NA}) \\
(\mathrm{NA}) \\
(\mathrm{NA}) \\
16,457\end{array}$ & $\begin{array}{l}(\mathrm{NA}) \\
(\mathrm{NA}) \\
(\mathrm{NA}) \\
(\mathrm{NA}) \\
17.0\end{array}$ & $\begin{array}{r}(\mathrm{NA}) \\
(\mathrm{NA}) \\
(\mathrm{NA}) \\
(\mathrm{NA}) \\
15,557\end{array}$ & $\begin{array}{r}\text { (NA) } \\
\text { (NA) } \\
\text { (NA) } \\
\text { (NA) } \\
5,481\end{array}$ & $\begin{array}{l}\text { (NA) } \\
\text { (NA) } \\
\text { (NA) } \\
\text { (NA) } \\
35.2\end{array}$ \\
\hline
\end{tabular}

See footnotes at end of table. 
Table B-2.

Poverty Status of People by Age, Race, and Hispanic Origin: 1959 to 2005-Con.

(Numbers in thousands. People as of March of the following year)

\begin{tabular}{|c|c|c|c|c|c|c|c|c|c|c|c|c|}
\hline \multirow{4}{*}{$\begin{array}{l}\text { Race, Hispanic } \\
\text { origin, and year }\end{array}$} & \multicolumn{6}{|c|}{ Under 18 years } & \multicolumn{3}{|c|}{18 to 64 years } & \multicolumn{3}{|c|}{65 years and older } \\
\hline & \multicolumn{3}{|c|}{ All people } & \multicolumn{3}{|c|}{ Related children in families } & \multirow[b]{3}{*}{ Total } & \multirow{2}{*}{\multicolumn{2}{|c|}{ Below poverty }} & \multirow[b]{3}{*}{ Total } & \multirow{2}{*}{\multicolumn{2}{|c|}{ Below poverty }} \\
\hline & \multirow[b]{2}{*}{ Total } & \multicolumn{2}{|c|}{ Below poverty } & \multirow[b]{2}{*}{ Total } & \multicolumn{2}{|c|}{ Below poverty } & & & & & & \\
\hline & & Number & Percent & & Number & Percent & & Number & Percent & & Number & Percent \\
\hline \multicolumn{13}{|l|}{ WHITE ALONE ${ }^{7}$} \\
\hline $\begin{array}{l}2005 \ldots \ldots \ldots \ldots \\
2004^{1} \ldots \ldots \ldots \ldots \ldots \\
2003 \ldots \ldots \ldots \ldots \\
2002 \ldots \ldots \ldots \ldots\end{array}$ & $\begin{array}{l}56,075 \\
56,053 \\
55,779 \\
55,703\end{array}$ & $\begin{array}{l}8,085 \\
8,308 \\
7,985 \\
7,549\end{array}$ & $\begin{array}{l}14.4 \\
14.8 \\
14.3 \\
13.6\end{array}$ & $\begin{array}{l}55,152 \\
55,212 \\
54,989 \\
54,900\end{array}$ & $\begin{array}{l}7,652 \\
7,876 \\
7,624 \\
7,203\end{array}$ & $\begin{array}{l}13.9 \\
14.3 \\
13.9 \\
13.1\end{array}$ & $\begin{array}{l}148,450 \\
146,974 \\
145,783 \\
144,694\end{array}$ & $\begin{array}{l}14,086 \\
14,486 \\
13,622 \\
13,178\end{array}$ & $\begin{array}{l}9.5 \\
9.9 \\
9.3 \\
9.1\end{array}$ & $\begin{array}{l}30,905 \\
30,714 \\
30,303 \\
29,980\end{array}$ & $\begin{array}{l}2,700 \\
2,534 \\
2,666 \\
2,739\end{array}$ & $\begin{array}{l}8.7 \\
8.3 \\
8.8 \\
9.1\end{array}$ \\
\hline \multicolumn{13}{|l|}{ WHITE ${ }^{8}$} \\
\hline $\begin{array}{l}2001 \ldots \\
2000^{2} \ldots \\
1999^{3} \ldots \\
1998 \ldots\end{array}$ & $\begin{array}{l}56,089 \\
55,980 \\
55,833 \\
56,016\end{array}$ & $\begin{array}{l}7,527 \\
7,307 \\
7,639 \\
8,443\end{array}$ & $\begin{array}{l}13.4 \\
13.1 \\
13.7 \\
15.1\end{array}$ & $\begin{array}{l}55,238 \\
55,021 \\
54,873 \\
55,126\end{array}$ & $\begin{array}{l}7,086 \\
6,834 \\
7,194 \\
7,935\end{array}$ & $\begin{array}{l}12.8 \\
12.4 \\
13.1 \\
14.4\end{array}$ & $\begin{array}{l}143,796 \\
142,164 \\
139,974 \\
138,061\end{array}$ & $\begin{array}{l}12,555 \\
11,754 \\
12,085 \\
12,456\end{array}$ & $\begin{array}{l}8.7 \\
8.3 \\
8.6 \\
9.0\end{array}$ & $\begin{array}{l}29,790 \\
29,703 \\
29,553 \\
28,759\end{array}$ & $\begin{array}{l}2,656 \\
2,584 \\
2,446 \\
2,555\end{array}$ & $\begin{array}{l}8.9 \\
8.7 \\
8.3 \\
8.9\end{array}$ \\
\hline $\begin{array}{l}1997 \ldots \ldots \ldots \ldots \ldots \\
1996 \ldots \ldots \ldots \ldots \\
1995 \ldots \ldots \ldots \ldots \\
1994 \ldots \ldots \ldots \ldots \\
1993 \ldots \ldots \ldots \ldots\end{array}$ & $\begin{array}{l}55,863 \\
55,606 \\
55,444 \\
55,186 \\
54,639\end{array}$ & $\begin{array}{l}8,990 \\
9,044 \\
8,981 \\
9,346 \\
9,752\end{array}$ & $\begin{array}{l}16.1 \\
16.3 \\
16.2 \\
16.9 \\
17.8\end{array}$ & $\begin{array}{l}54,870 \\
54,599 \\
54,532 \\
54,221 \\
53,614\end{array}$ & $\begin{array}{l}8,441 \\
8,488 \\
8,474 \\
8,826 \\
9,123\end{array}$ & $\begin{array}{l}15.4 \\
15.5 \\
15.5 \\
16.3 \\
17.0\end{array}$ & $\begin{array}{l}136,784 \\
135,586 \\
134,149 \\
133,289 \\
132,680\end{array}$ & $\begin{array}{l}12,838 \\
12,940 \\
12,869 \\
13,187 \\
13,535\end{array}$ & $\begin{array}{r}9.4 \\
9.5 \\
9.6 \\
9.9 \\
10.2\end{array}$ & $\begin{array}{l}28,553 \\
28,464 \\
28,436 \\
27,985 \\
27,580\end{array}$ & $\begin{array}{l}2,569 \\
2,667 \\
2,572 \\
2,846 \\
2,939\end{array}$ & $\begin{array}{r}9.0 \\
9.4 \\
9.0 \\
10.2 \\
10.7\end{array}$ \\
\hline $\begin{array}{l}1992^{4} \ldots \ldots \ldots \ldots \\
1991^{5} \ldots \ldots \ldots \ldots \ldots \\
1990 \ldots \ldots \ldots \ldots \\
1989 \ldots \ldots \ldots \ldots \\
1988^{6} \ldots \ldots \ldots \ldots \ldots\end{array}$ & $\begin{array}{l}54,110 \\
52,523 \\
51,929 \\
51,400 \\
51,203\end{array}$ & $\begin{array}{l}9,399 \\
8,848 \\
8,232 \\
7,599 \\
7,435\end{array}$ & $\begin{array}{l}17.4 \\
16.8 \\
15.9 \\
14.8 \\
14.5\end{array}$ & $\begin{array}{l}53,110 \\
51,627 \\
51,028 \\
50,704 \\
50,590\end{array}$ & $\begin{array}{l}8,752 \\
8,316 \\
7,696 \\
7,164 \\
7,095\end{array}$ & $\begin{array}{l}16.5 \\
16.1 \\
15.1 \\
14.1 \\
14.0\end{array}$ & $\begin{array}{l}131,694 \\
130,312 \\
129,784 \\
128,974 \\
128,031\end{array}$ & $\begin{array}{l}12,871 \\
12,097 \\
11,387 \\
10,647 \\
10,687\end{array}$ & $\begin{array}{l}9.8 \\
9.3 \\
8.8 \\
8.3 \\
8.3\end{array}$ & $\begin{array}{l}27,256 \\
27,297 \\
26,898 \\
26,479 \\
26,001\end{array}$ & $\begin{array}{l}2,989 \\
2,802 \\
2,707 \\
2,539 \\
2,593\end{array}$ & $\begin{array}{r}11.0 \\
10.3 \\
10.1 \\
9.6 \\
10.0\end{array}$ \\
\hline $\begin{array}{l}1987^{6} \ldots \ldots \ldots \ldots \\
1986 \ldots \ldots \ldots \\
1985 \ldots \ldots \ldots \\
1984 \ldots \ldots \ldots \ldots \\
1983 \ldots \ldots \ldots \ldots \ldots\end{array}$ & $\begin{array}{l}51,012 \\
51,111 \\
51,031 \\
50,814 \\
50,726\end{array}$ & $\begin{array}{l}7,788 \\
8,209 \\
8,253 \\
8,472 \\
8,862\end{array}$ & $\begin{array}{l}15.3 \\
16.1 \\
16.2 \\
16.7 \\
17.5\end{array}$ & $\begin{array}{l}50,360 \\
50,356 \\
50,358 \\
50,192 \\
50,183\end{array}$ & $\begin{array}{l}7,398 \\
7,714 \\
7,838 \\
8,086 \\
8,534\end{array}$ & $\begin{array}{l}14.7 \\
15.3 \\
15.6 \\
16.1 \\
17.0\end{array}$ & $\begin{array}{l}126,991 \\
125,998 \\
125,258 \\
123,922 \\
123,014\end{array}$ & \begin{tabular}{r|}
10,703 \\
11,285 \\
11,909 \\
11,904 \\
12,347
\end{tabular} & $\begin{array}{r}8.4 \\
9.0 \\
9.5 \\
9.6 \\
10.0\end{array}$ & $\begin{array}{l}25,602 \\
25,173 \\
24,629 \\
24,206 \\
23,754\end{array}$ & $\begin{array}{l}2,704 \\
2,689 \\
2,698 \\
2,579 \\
2,776\end{array}$ & $\begin{array}{l}10.6 \\
10.7 \\
11.0 \\
10.7 \\
11.7\end{array}$ \\
\hline $\begin{array}{l}1982 \ldots \ldots \ldots \ldots \\
1981 \ldots \ldots \ldots \\
1980 \ldots \ldots \ldots \\
1979 \ldots \ldots \ldots \\
1978 \ldots \ldots \ldots\end{array}$ & $\begin{array}{l}50,920 \\
51,140 \\
51,653 \\
52,262 \\
51,669\end{array}$ & $\begin{array}{l}8,678 \\
7,785 \\
7,181 \\
6,193 \\
5,831\end{array}$ & $\begin{array}{l}17.0 \\
15.2 \\
13.9 \\
11.8 \\
11.3\end{array}$ & $\begin{array}{l}50,305 \\
50,553 \\
51,002 \\
51,687 \\
51,409\end{array}$ & $\begin{array}{l}8,282 \\
7,429 \\
6,817 \\
5,909 \\
5,674\end{array}$ & $\begin{array}{l}16.5 \\
14.7 \\
13.4 \\
11.4 \\
11.0\end{array}$ & $\begin{array}{l}121,766 \\
120,574 \\
118,935 \\
117,583 \\
113,832\end{array}$ & $\begin{array}{r}11,971 \\
10,790 \\
9,478 \\
8,110 \\
7,897\end{array}$ & $\begin{array}{l}9.8 \\
8.9 \\
8.0 \\
6.9 \\
6.9\end{array}$ & $\begin{array}{l}23,234 \\
22,791 \\
22,325 \\
21,898 \\
20,950\end{array}$ & $\begin{array}{l}2,870 \\
2,978 \\
3,042 \\
2,911 \\
2,530\end{array}$ & $\begin{array}{l}12.4 \\
13.1 \\
13.6 \\
13.3 \\
12.1\end{array}$ \\
\hline $\begin{array}{l}1977 \ldots \ldots \ldots \\
1976 \ldots \ldots \ldots \\
1975 \ldots \ldots \ldots \\
1974 \ldots \ldots \ldots \\
1973 \ldots \ldots \ldots\end{array}$ & $\begin{array}{r}52,563 \\
53,428 \\
54,405 \\
55,590 \\
\text { (NA) }\end{array}$ & $\begin{array}{r}6,097 \\
6,189 \\
6,927 \\
6,223 \\
\text { (NA) }\end{array}$ & $\begin{array}{r}11.6 \\
11.6 \\
12.7 \\
11.2 \\
(\mathrm{NA})\end{array}$ & $\begin{array}{l}52,299 \\
53,167 \\
54,126 \\
55,320 \\
56,211\end{array}$ & $\begin{array}{l}5,943 \\
6,034 \\
6,748 \\
6,079 \\
5,462\end{array}$ & $\begin{array}{r}11.4 \\
11.3 \\
12.5 \\
11.0 \\
9.7\end{array}$ & $\begin{array}{r}112,374 \\
110,717 \\
109,105 \\
107,579 \\
(\mathrm{NA})\end{array}$ & $\begin{array}{r}7,893 \\
7,890 \\
8,210 \\
7,053 \\
\text { (NA) }\end{array}$ & $\begin{array}{r}7.0 \\
7.1 \\
7.5 \\
6.6 \\
(\mathrm{NA})\end{array}$ & $\begin{array}{r}20,316 \\
20,020 \\
19,654 \\
19,206 \\
(\mathrm{NA})\end{array}$ & $\begin{array}{l}2,426 \\
2,633 \\
2,634 \\
2,460 \\
2,698\end{array}$ & $\begin{array}{l}11.9 \\
13.2 \\
13.4 \\
12.8 \\
14.4\end{array}$ \\
\hline $\begin{array}{l}1972 \ldots \ldots \ldots \ldots \ldots \\
1971 \ldots \ldots \ldots \ldots \ldots \\
1970 \ldots \ldots \ldots \ldots \\
1969 \ldots \ldots \ldots \ldots \\
1968 \ldots \ldots \ldots \ldots\end{array}$ & $\begin{array}{l}\text { (NA) } \\
\text { (NA) } \\
\text { (NA) } \\
\text { (NA) } \\
\text { (NA) }\end{array}$ & $\begin{array}{l}\text { (NA) } \\
\text { (NA) } \\
\text { (NA) } \\
\text { (NA) } \\
\text { (NA) }\end{array}$ & $\begin{array}{l}\text { (NA) } \\
\text { (NA) } \\
\text { (NA) } \\
\text { (NA) } \\
\text { (NA) }\end{array}$ & $\begin{array}{r}57,181 \\
58,119 \\
58,472 \\
58,578 \\
\text { (NA) }\end{array}$ & $\begin{array}{l}5,784 \\
6,341 \\
6,138 \\
5,667 \\
6,373\end{array}$ & $\begin{array}{r}10.1 \\
10.9 \\
10.5 \\
9.7 \\
10.7\end{array}$ & $\begin{array}{l}\text { (NA) } \\
\text { (NA) } \\
\text { (NA) } \\
\text { (NA) } \\
\text { (NA) }\end{array}$ & $\begin{array}{l}\text { (NA) } \\
\text { (NA) } \\
\text { (NA) } \\
\text { (NA) } \\
\text { (NA) }\end{array}$ & $\begin{array}{l}\text { (NA) } \\
\text { (NA) } \\
\text { (NA) } \\
\text { (NA) } \\
\text { (NA) }\end{array}$ & $\begin{array}{r}(\mathrm{NA}) \\
(\mathrm{NA}) \\
(\mathrm{NA}) \\
(\mathrm{NA}) \\
17,062\end{array}$ & $\begin{array}{l}3,072 \\
3,605 \\
4,011 \\
4,052 \\
3,939\end{array}$ & $\begin{array}{l}16.8 \\
19.9 \\
22.6 \\
23.3 \\
23.1\end{array}$ \\
\hline $\begin{array}{l}1967 \ldots \ldots \ldots \\
1966 \ldots \ldots \ldots \\
1965 \ldots \ldots \ldots \\
1960 \ldots \ldots \\
1959 \ldots \ldots \ldots\end{array}$ & $\begin{array}{l}\text { (NA) } \\
\text { (NA) } \\
\text { (NA) } \\
\text { (NA) } \\
\text { (NA) }\end{array}$ & $\begin{array}{l}\text { (NA) } \\
\text { (NA) } \\
\text { (NA) } \\
\text { (NA) } \\
\text { (NA) }\end{array}$ & $\begin{array}{l}\text { (NA) } \\
\text { (NA) } \\
\text { (NA) } \\
\text { (NA) } \\
\text { (NA) }\end{array}$ & $\begin{array}{l}\text { (NA) } \\
\text { (NA) } \\
\text { (NA) } \\
\text { (NA) } \\
\text { (NA) }\end{array}$ & $\begin{array}{r}6,729 \\
7,204 \\
8,595 \\
11,229 \\
11,386\end{array}$ & $\begin{array}{l}11.3 \\
12.1 \\
14.4 \\
20.0 \\
20.6\end{array}$ & $\begin{array}{l}\text { (NA) } \\
\text { (NA) } \\
\text { (NA) } \\
\text { (NA) } \\
\text { (NA) }\end{array}$ & $\begin{array}{l}\text { (NA) } \\
\text { (NA) } \\
\text { (NA) } \\
\text { (NA) } \\
\text { (NA) }\end{array}$ & $\begin{array}{l}\text { (NA) } \\
\text { (NA) } \\
\text { (NA) } \\
\text { (NA) } \\
\text { (NA) }\end{array}$ & $\begin{array}{r}16,791 \\
16,514 \\
(\mathrm{NA}) \\
(\mathrm{NA}) \\
(\mathrm{NA})\end{array}$ & $\begin{array}{r}4,646 \\
4,357 \\
(\mathrm{NA}) \\
(\mathrm{NA}) \\
4,744\end{array}$ & $\begin{array}{l}27.7 \\
26.4 \\
\text { (NA) } \\
\text { (NA) } \\
33.1\end{array}$ \\
\hline
\end{tabular}


Table B-2.

Poverty Status of People by Age, Race, and Hispanic Origin: 1959 to 2005-Con.

(Numbers in thousands. People as of March of the following year)

\begin{tabular}{|c|c|c|c|c|c|c|c|c|c|c|c|c|}
\hline \multirow{4}{*}{$\begin{array}{l}\text { Race, Hispanic } \\
\text { origin, and year }\end{array}$} & \multicolumn{6}{|c|}{ Under 18 years } & \multicolumn{3}{|c|}{18 to 64 years } & \multicolumn{3}{|c|}{65 years and older } \\
\hline & \multicolumn{3}{|c|}{ All people } & \multicolumn{3}{|c|}{ Related children in families } & \multirow[b]{3}{*}{ Total } & \multirow{2}{*}{\multicolumn{2}{|c|}{ Below poverty }} & \multirow[b]{3}{*}{ Total } & \multirow{2}{*}{\multicolumn{2}{|c|}{ Below poverty }} \\
\hline & \multirow[b]{2}{*}{ Total } & \multicolumn{2}{|c|}{ Below poverty } & \multirow[b]{2}{*}{ Total } & \multicolumn{2}{|c|}{ Below poverty } & & & & & & \\
\hline & & Number & Percent & & Number & Percent & & Number & Percent & & Number & Percent \\
\hline \multicolumn{13}{|l|}{$\begin{array}{l}\text { WHITE ALONE, NOT } \\
\text { HISPANIC }^{7}\end{array}$} \\
\hline $\begin{array}{l}2005 \ldots \ldots \ldots \ldots \\
2004^{1} \ldots \ldots \ldots \ldots \ldots \\
2003 \ldots \ldots \ldots \ldots \\
2002 \ldots \ldots \ldots \ldots\end{array}$ & $\begin{array}{l}42,523 \\
42,978 \\
43,150 \\
43,614\end{array}$ & $\begin{array}{l}4,254 \\
4,519 \\
4,233 \\
4,090\end{array}$ & $\begin{array}{r}10.0 \\
10.5 \\
9.8 \\
9.4\end{array}$ & $\begin{array}{l}41,867 \\
42,363 \\
42,547 \\
43,017\end{array}$ & $\begin{array}{l}3,973 \\
4,190 \\
3,957 \\
3,848\end{array}$ & $\begin{array}{l}9.5 \\
9.9 \\
9.3 \\
8.9\end{array}$ & $\begin{array}{l}124,326 \\
123,481 \\
123,110 \\
122,511\end{array}$ & $\begin{array}{r}9,708 \\
10,236 \\
9,391 \\
9,157\end{array}$ & $\begin{array}{l}7.8 \\
8.3 \\
7.6 \\
7.5\end{array}$ & $\begin{array}{l}28,704 \\
28,639 \\
28,335 \\
28,018\end{array}$ & $\begin{array}{l}2,264 \\
2,153 \\
2,277 \\
2,321\end{array}$ & $\begin{array}{l}7.9 \\
7.5 \\
8.0 \\
8.3\end{array}$ \\
\hline \multicolumn{13}{|l|}{$\begin{array}{l}\text { WHITE, NOT } \\
\text { HISPANIC }^{8}\end{array}$} \\
\hline $\begin{array}{l}2001 \ldots \ldots \ldots \ldots \\
2000^{2} \ldots \ldots \ldots \ldots \ldots \ldots \\
1999^{3} \ldots \ldots \ldots \ldots \ldots \\
1998 \ldots \ldots \ldots \ldots \ldots\end{array}$ & $\begin{array}{l}44,095 \\
44,244 \\
44,272 \\
45,355\end{array}$ & $\begin{array}{l}4,194 \\
4,018 \\
4,155 \\
4,822\end{array}$ & $\begin{array}{r}9.5 \\
9.1 \\
9.4 \\
10.6\end{array}$ & $\begin{array}{l}43,459 \\
43,554 \\
43,570 \\
44,670\end{array}$ & $\begin{array}{l}3,887 \\
3,715 \\
3,832 \\
4,458\end{array}$ & $\begin{array}{r}8.9 \\
8.5 \\
8.8 \\
10.0\end{array}$ & $\begin{array}{l}122,470 \\
121,499 \\
120,341 \\
120,282\end{array}$ & $\begin{array}{l}8,811 \\
8,130 \\
8,462 \\
8,760\end{array}$ & $\begin{array}{l}7.2 \\
6.7 \\
7.0 \\
7.3\end{array}$ & $\begin{array}{l}27,973 \\
27,948 \\
27,952 \\
27,118\end{array}$ & $\begin{array}{l}2,266 \\
2,218 \\
2,118 \\
2,217\end{array}$ & $\begin{array}{l}8.1 \\
7.9 \\
7.6 \\
8.2\end{array}$ \\
\hline $\begin{array}{l}1997 \ldots \ldots \ldots \ldots \\
1996 \ldots \ldots \ldots \ldots \ldots \\
1995 \ldots \ldots \ldots \ldots \\
1994 \ldots \ldots \ldots \ldots \\
1993 \ldots \ldots \ldots \ldots \ldots\end{array}$ & $\begin{array}{l}45,491 \\
45,605 \\
45,689 \\
46,668 \\
46,096\end{array}$ & $\begin{array}{l}5,204 \\
5,072 \\
5,115 \\
5,823 \\
6,255\end{array}$ & $\begin{array}{l}11.4 \\
11.1 \\
11.2 \\
12.5 \\
13.6\end{array}$ & $\begin{array}{l}44,665 \\
44,844 \\
44,973 \\
45,874 \\
45,322\end{array}$ & $\begin{array}{l}4,759 \\
4,656 \\
4,745 \\
5,404 \\
5,819\end{array}$ & $\begin{array}{l}10.7 \\
10.4 \\
10.6 \\
11.8 \\
12.8\end{array}$ & $\begin{array}{l}119,373 \\
118,822 \\
118,228 \\
119,192 \\
118,475\end{array}$ & $\begin{array}{l}9,088 \\
9,074 \\
8,908 \\
9,732 \\
9,964\end{array}$ & $\begin{array}{l}7.6 \\
7.6 \\
7.5 \\
8.2 \\
8.4\end{array}$ & $\begin{array}{l}26,995 \\
27,033 \\
27,034 \\
26,684 \\
26,272\end{array}$ & $\begin{array}{l}2,200 \\
2,316 \\
2,243 \\
2,556 \\
2,663\end{array}$ & $\begin{array}{r}8.1 \\
8.6 \\
8.3 \\
9.6 \\
10.1\end{array}$ \\
\hline $\begin{array}{l}1992^{4} \ldots \ldots \ldots \ldots \ldots \\
1991^{5} \ldots \ldots \ldots \ldots \ldots \\
1990 \ldots \ldots \ldots \ldots \\
1989 \ldots \ldots \ldots \ldots \\
1988^{6} \ldots \ldots \ldots \ldots \ldots\end{array}$ & $\begin{array}{l}45,590 \\
45,236 \\
44,797 \\
44,492 \\
44,438\end{array}$ & $\begin{array}{l}6,017 \\
5,918 \\
5,532 \\
5,110 \\
4,888\end{array}$ & $\begin{array}{l}13.2 \\
13.1 \\
12.3 \\
11.5 \\
11.0\end{array}$ & $\begin{array}{l}44,833 \\
44,506 \\
44,045 \\
43,938 \\
43,910\end{array}$ & $\begin{array}{l}5,558 \\
5,497 \\
5,106 \\
4,779 \\
4,594\end{array}$ & $\begin{array}{r}12.4 \\
12.4 \\
11.6 \\
10.9 \\
10.5\end{array}$ & $\begin{array}{l}117,386 \\
117,672 \\
117,477 \\
116,983 \\
116,479\end{array}$ & $\begin{array}{l}9,461 \\
9,244 \\
8,619 \\
8,154 \\
8,293\end{array}$ & $\begin{array}{l}8.1 \\
7.9 \\
7.3 \\
7.0 \\
7.1\end{array}$ & $\begin{array}{l}26,025 \\
26,208 \\
25,854 \\
25,504 \\
25,044\end{array}$ & $\begin{array}{l}2,724 \\
2,580 \\
2,471 \\
2,335 \\
2,384\end{array}$ & $\begin{array}{r}10.5 \\
9.8 \\
9.6 \\
9.2 \\
9.5\end{array}$ \\
\hline 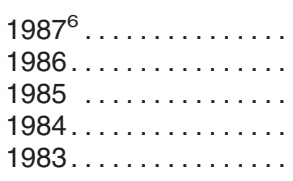 & $\begin{array}{l}44,461 \\
44,664 \\
44,752 \\
44,886 \\
44,830\end{array}$ & $\begin{array}{l}5,230 \\
5,789 \\
5,745 \\
6,156 \\
6,649\end{array}$ & $\begin{array}{l}11.8 \\
13.0 \\
12.8 \\
13.7 \\
14.8\end{array}$ & $\begin{array}{l}43,907 \\
44,041 \\
44,199 \\
44,349 \\
44,374\end{array}$ & $\begin{array}{l}4,902 \\
5,388 \\
5,421 \\
5,828 \\
6,381\end{array}$ & $\begin{array}{l}11.2 \\
12.2 \\
12.3 \\
13.1 \\
14.4\end{array}$ & $\begin{array}{l}115,721 \\
115,157 \\
114,969 \\
114,180 \\
113,570\end{array}$ & $\begin{array}{r}8,327 \\
8,963 \\
9,608 \\
9,734 \\
10,279\end{array}$ & $\begin{array}{l}7.2 \\
7.8 \\
8.4 \\
8.5 \\
9.1\end{array}$ & $\begin{array}{l}24,754 \\
24,298 \\
23,734 \\
23,402 \\
22,992\end{array}$ & $\begin{array}{l}2,472 \\
2,492 \\
2,486 \\
2,410 \\
2,610\end{array}$ & $\begin{array}{l}10.0 \\
10.3 \\
10.5 \\
10.3 \\
11.4\end{array}$ \\
\hline $\begin{array}{l}1982 \ldots \ldots \ldots \ldots \ldots \\
1981 \ldots \ldots \ldots \ldots \ldots \\
1980 \ldots \ldots \ldots \ldots \\
1979 \ldots \ldots \ldots \ldots \ldots \\
1978 \ldots \ldots \ldots \ldots \ldots\end{array}$ & $\begin{array}{l}45,531 \\
45,950 \\
46,578 \\
46,967 \\
46,819\end{array}$ & $\begin{array}{l}6,566 \\
5,946 \\
5,510 \\
4,730 \\
4,506\end{array}$ & \begin{tabular}{r|}
14.4 \\
12.9 \\
11.8 \\
10.1 \\
9.6
\end{tabular} & $\begin{array}{l}45,001 \\
45,440 \\
45,989 \\
46,448 \\
46,606\end{array}$ & $\begin{array}{l}6,229 \\
5,639 \\
5,174 \\
4,476 \\
4,383\end{array}$ & \begin{tabular}{r|}
13.8 \\
12.4 \\
11.3 \\
9.6 \\
9.4
\end{tabular} & $\begin{array}{c}113,717 \\
112,722 \\
111,460 \\
110,509 \\
107,481\end{array}$ & $\begin{array}{r}10,082 \\
9,207 \\
7,990 \\
6,930 \\
6,837\end{array}$ & $\begin{array}{l}8.9 \\
8.2 \\
7.2 \\
6.3 \\
6.4\end{array}$ & $\begin{array}{l}22,655 \\
22,237 \\
21,760 \\
21,339 \\
20,431\end{array}$ & $\begin{array}{l}2,714 \\
2,834 \\
2,865 \\
2,759 \\
2,412\end{array}$ & $\begin{array}{l}12.0 \\
12.7 \\
13.2 \\
12.9 \\
11.8\end{array}$ \\
\hline $\begin{array}{l}1977 \ldots \ldots \ldots \ldots \ldots \\
1976 \ldots \ldots \ldots \ldots \ldots \\
1975 \ldots \ldots \ldots \ldots \ldots \\
1974 \ldots \ldots \ldots \ldots \ldots\end{array}$ & $\begin{array}{l}47,689 \\
48,824 \\
49,670 \\
50,759\end{array}$ & $\begin{array}{l}4,714 \\
4,799 \\
5,342 \\
4,820\end{array}$ & $\begin{array}{r}9.9 \\
9.8 \\
10.8 \\
9.5\end{array}$ & $\begin{array}{l}47,459 \\
48,601 \\
49,421 \\
50,520\end{array}$ & $\begin{array}{l}4,582 \\
4,664 \\
5,185 \\
4,697\end{array}$ & $\begin{array}{r}9.7 \\
9.6 \\
10.5 \\
9.3\end{array}$ & $\begin{array}{l}106,063 \\
104,846 \\
103,496 \\
101,894\end{array}$ & $\begin{array}{l}6,772 \\
6,720 \\
7,039 \\
6,051\end{array}$ & $\begin{array}{l}6.4 \\
6.4 \\
6.8 \\
5.9\end{array}$ & $\begin{array}{l}19,812 \\
19,565 \\
19,251 \\
18,810\end{array}$ & $\begin{array}{l}2,316 \\
2,506 \\
2,503 \\
2,346\end{array}$ & $\begin{array}{l}11.7 \\
12.8 \\
13.0 \\
12.5\end{array}$ \\
\hline
\end{tabular}


Table B-2.

Poverty Status of People by Age, Race, and Hispanic Origin: 1959 to 2005-Con.

(Numbers in thousands. People as of March of the following year)

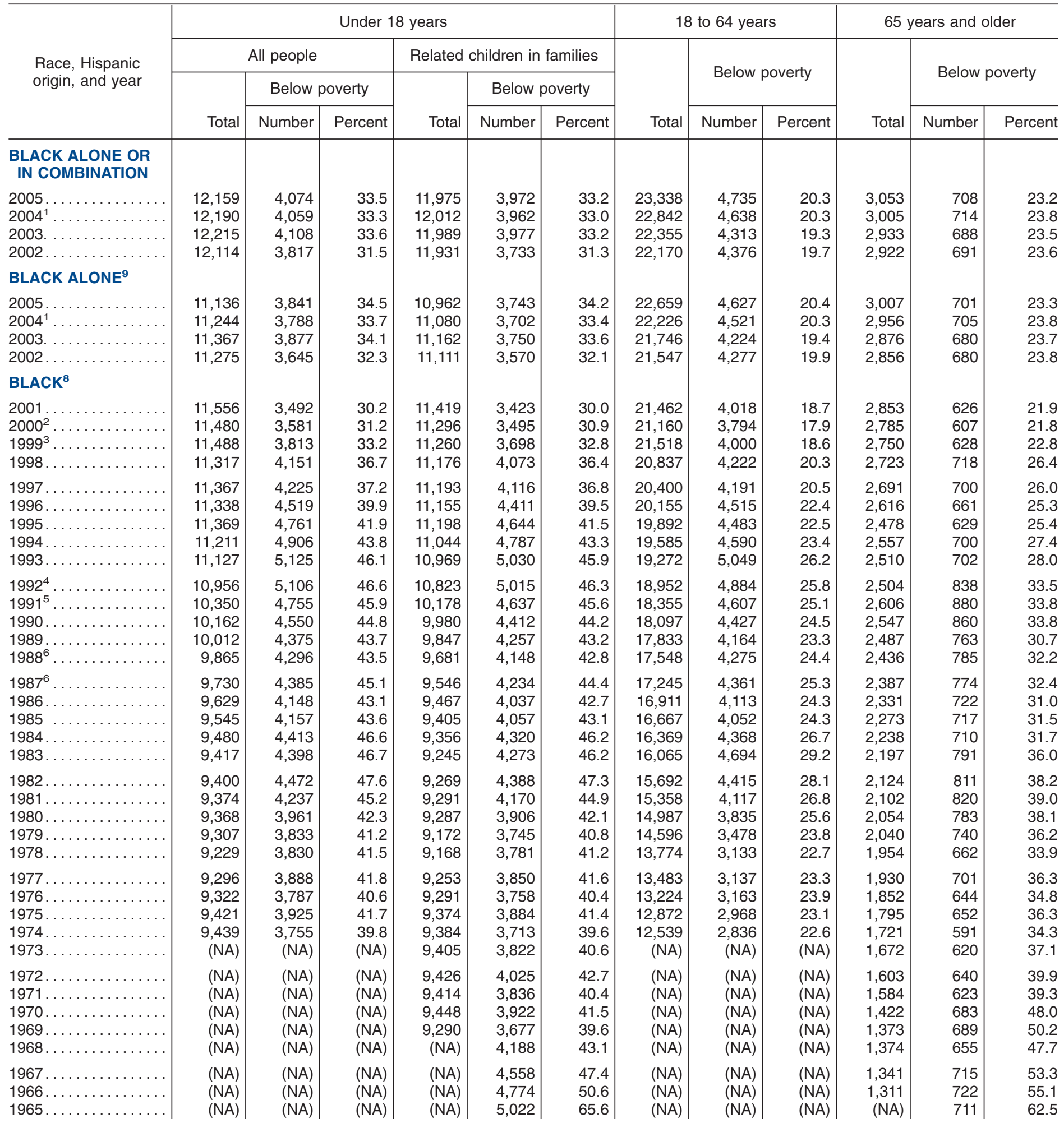

See footnotes at end of table. 
Table B-2.

Poverty Status of People by Age, Race, and Hispanic Origin: 1959 to 2005-Con.

(Numbers in thousands. People as of March of the following year)

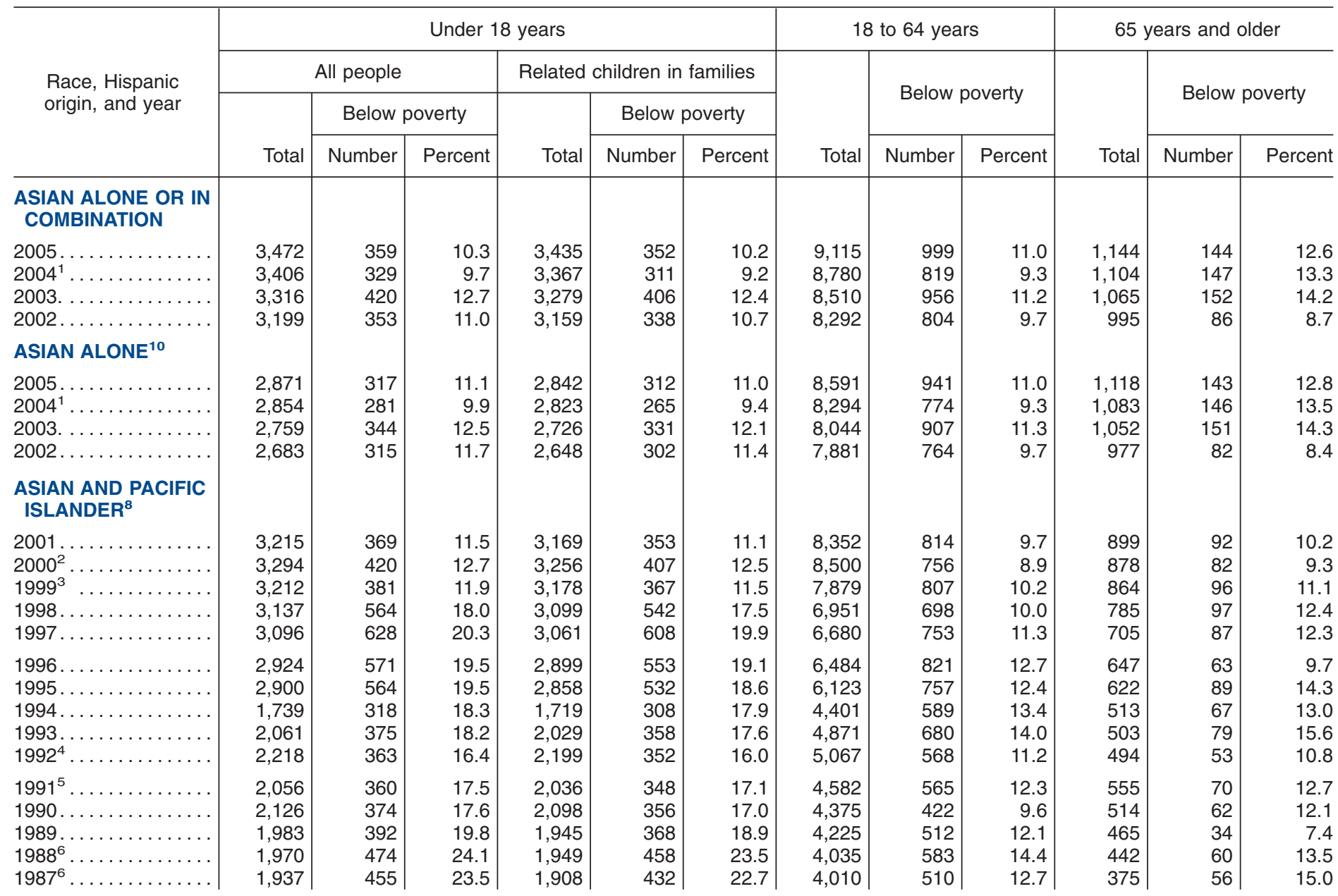

See footnotes at end of table. 
Table B-2.

Poverty Status of People by Age, Race, and Hispanic Origin: 1959 to 2005-Con.

(Numbers in thousands. People as of March of the following year)

\begin{tabular}{|c|c|c|c|c|c|c|c|c|c|c|c|c|}
\hline \multirow{4}{*}{$\begin{array}{l}\text { Race, Hispanic } \\
\text { origin, and year }\end{array}$} & \multicolumn{6}{|c|}{ Under 18 years } & \multicolumn{3}{|c|}{18 to 64 years } & \multicolumn{3}{|c|}{65 years and older } \\
\hline & \multicolumn{3}{|c|}{ All people } & \multicolumn{3}{|c|}{ Related children in families } & \multirow[b]{3}{*}{ Total } & \multirow{2}{*}{\multicolumn{2}{|c|}{ Below poverty }} & \multirow[b]{3}{*}{ Total } & \multirow{2}{*}{\multicolumn{2}{|c|}{ Below poverty }} \\
\hline & \multirow[b]{2}{*}{ Total } & \multicolumn{2}{|c|}{ Below poverty } & \multirow[b]{2}{*}{ Total } & \multicolumn{2}{|c|}{ Below poverty } & & & & & & \\
\hline & & Number & Percent & & Number & Percent & & Number & Percent & & Number & Percent \\
\hline \multicolumn{13}{|l|}{$\begin{array}{l}\text { HISPANIC } \\
\text { (ANY RACE) }\end{array}$} \\
\hline $\begin{array}{l}2005 . \\
2004^{1} .\end{array}$ & $\begin{array}{l}14,654 \\
14,173\end{array}$ & $\begin{array}{l}4,143 \\
4,098\end{array}$ & $\begin{array}{l}28.3 \\
28.9\end{array}$ & $\begin{array}{l}14,361 \\
13,929\end{array}$ & $\begin{array}{l}3,977 \\
3,985\end{array}$ & $\begin{array}{l}27.7 \\
28.6\end{array}$ & $\begin{array}{l}26,051 \\
25,324\end{array}$ & $\begin{array}{l}4,765 \\
4,620\end{array}$ & $\begin{array}{l}18.3 \\
18.2\end{array}$ & $\begin{array}{l}2,315 \\
2,194\end{array}$ & $\begin{array}{l}460 \\
403\end{array}$ & $\begin{array}{l}19.9 \\
18.4\end{array}$ \\
\hline $\begin{array}{l}2003 \ldots \ldots \ldots \\
2002 \ldots \ldots \ldots \\
2001 \ldots \ldots \ldots \\
2000^{2} \ldots \ldots \ldots \\
1999^{3} \ldots \ldots \ldots\end{array}$ & $\begin{array}{l}13,730 \\
13,210 \\
12,763 \\
12,399 \\
12,188\end{array}$ & $\begin{array}{l}4,077 \\
3,782 \\
3,570 \\
3,522 \\
3,693\end{array}$ & $\begin{array}{l}29.7 \\
28.6 \\
28.0 \\
28.4 \\
30.3\end{array}$ & $\begin{array}{l}13,519 \\
12,971 \\
12,539 \\
12,115 \\
11,912\end{array}$ & $\begin{array}{l}3,982 \\
3,653 \\
3,433 \\
3,342 \\
3,561\end{array}$ & $\begin{array}{l}29.5 \\
28.2 \\
27.4 \\
27.6 \\
29.9\end{array}$ & $\begin{array}{l}24,490 \\
23,952 \\
22,653 \\
21,734 \\
20,782\end{array}$ & $\begin{array}{l}4,568 \\
4,334 \\
4,014 \\
3,844 \\
3,843\end{array}$ & $\begin{array}{l}18.7 \\
18.1 \\
17.7 \\
17.7 \\
18.5\end{array}$ & $\begin{array}{l}2,080 \\
2,053 \\
1,896 \\
1,822 \\
1,661\end{array}$ & $\begin{array}{l}406 \\
439 \\
413 \\
381 \\
340\end{array}$ & $\begin{array}{l}19.5 \\
21.4 \\
21.8 \\
20.9 \\
20.5\end{array}$ \\
\hline $\begin{array}{l}1998 \\
1997 \\
1996 \\
1995 \\
1994\end{array}$ & $\begin{array}{r}11,152 \\
10,802 \\
10,511 \\
10,213 \\
9,822\end{array}$ & $\begin{array}{l}3,837 \\
3,972 \\
4,237 \\
4,080 \\
4,075\end{array}$ & $\begin{array}{l}34.4 \\
36.8 \\
40.3 \\
40.0 \\
41.5\end{array}$ & $\begin{array}{r}10,921 \\
10,625 \\
10,255 \\
10,011 \\
9,621\end{array}$ & $\begin{array}{l}3,670 \\
3,865 \\
4,090 \\
3,938 \\
3,956\end{array}$ & $\begin{array}{l}33.6 \\
36.4 \\
39.9 \\
39.3 \\
41.1\end{array}$ & $\begin{array}{l}18,668 \\
18,217 \\
17,587 \\
16,673 \\
16,192\end{array}$ & $\begin{array}{l}3,877 \\
3,951 \\
4,089 \\
4,153 \\
4,018\end{array}$ & $\begin{array}{l}20.8 \\
21.7 \\
23.3 \\
24.9 \\
24.8\end{array}$ & $\begin{array}{l}1,696 \\
1,617 \\
1,516 \\
1,458 \\
1,428\end{array}$ & $\begin{array}{l}356 \\
384 \\
370 \\
342 \\
323\end{array}$ & $\begin{array}{l}21.0 \\
23.8 \\
24.4 \\
23.5 \\
22.6\end{array}$ \\
\hline $\begin{array}{c}1993 \ldots \\
1992^{4} \ldots \\
1991^{5} \ldots \\
1990 \ldots \\
1989 \ldots\end{array}$ & $\begin{array}{l}9,462 \\
9,081 \\
7,648 \\
7,457 \\
7,186\end{array}$ & $\begin{array}{l}3,873 \\
3,637 \\
3,094 \\
2,865 \\
2,603\end{array}$ & $\begin{array}{l}40.9 \\
40.0 \\
40.4 \\
38.4 \\
36.2\end{array}$ & $\begin{array}{l}9,188 \\
8,829 \\
7,473 \\
7,300 \\
7,040\end{array}$ & $\begin{array}{l}3,666 \\
3,440 \\
2,977 \\
2,750 \\
2,496\end{array}$ & $\begin{array}{l}39.9 \\
39.0 \\
39.8 \\
37.7 \\
35.5\end{array}$ & $\begin{array}{l}15,708 \\
15,268 \\
13,279 \\
12,857 \\
12,536\end{array}$ & $\begin{array}{l}3,956 \\
3,668 \\
3,008 \\
2,896 \\
2,616\end{array}$ & $\begin{array}{l}25.2 \\
24.0 \\
22.7 \\
22.5 \\
20.9\end{array}$ & $\begin{array}{l}1,390 \\
1,298 \\
1,143 \\
1,091 \\
1,024\end{array}$ & $\begin{array}{l}297 \\
287 \\
237 \\
245 \\
211\end{array}$ & $\begin{array}{l}21.4 \\
22.1 \\
20.8 \\
22.5 \\
20.6\end{array}$ \\
\hline $\begin{array}{l}1988^{6} \ldots \\
1987^{6} \ldots \\
1986 \ldots \\
1985 \ldots \\
1984 \ldots\end{array}$ & $\begin{array}{l}7,003 \\
6,792 \\
6,646 \\
6,475 \\
6,068\end{array}$ & $\begin{array}{l}2,631 \\
2,670 \\
2,507 \\
2,606 \\
2,376\end{array}$ & $\begin{array}{l}37.6 \\
39.3 \\
37.7 \\
40.3 \\
39.2\end{array}$ & $\begin{array}{l}6,908 \\
6,692 \\
6,511 \\
6,346 \\
5,982\end{array}$ & $\begin{array}{l}2,576 \\
2,606 \\
2,413 \\
2,512 \\
2,317\end{array}$ & $\begin{array}{l}37.3 \\
38.9 \\
37.1 \\
39.6 \\
38.7\end{array}$ & $\begin{array}{l}12,056 \\
11,718 \\
11,206 \\
10,685 \\
10,029\end{array}$ & $\begin{array}{l}2,501 \\
2,509 \\
2,406 \\
2,411 \\
2,254\end{array}$ & $\begin{array}{l}20.7 \\
21.4 \\
21.5 \\
22.6 \\
22.5\end{array}$ & $\begin{array}{r}1,005 \\
885 \\
906 \\
915 \\
819\end{array}$ & $\begin{array}{l}225 \\
243 \\
204 \\
219 \\
176\end{array}$ & $\begin{array}{l}22.4 \\
27.5 \\
22.5 \\
23.9 \\
21.5\end{array}$ \\
\hline $\begin{array}{l}1983 \ldots \ldots \ldots \ldots \\
1982 \ldots \ldots \ldots \ldots \\
1981 \ldots \ldots \ldots \ldots \\
1980 \ldots \ldots \ldots \ldots \\
1979 \ldots \ldots \ldots \ldots\end{array}$ & $\begin{array}{l}6,066 \\
5,527 \\
5,369 \\
5,276 \\
5,483\end{array}$ & $\begin{array}{l}2,312 \\
2,181 \\
1,925 \\
1,749 \\
1,535\end{array}$ & $\begin{array}{l}38.1 \\
39.5 \\
35.9 \\
33.2 \\
28.0\end{array}$ & $\begin{array}{l}5,977 \\
5,436 \\
5,291 \\
5,211 \\
5,426\end{array}$ & $\begin{array}{l}2,251 \\
2,117 \\
1,874 \\
1,718 \\
1,505\end{array}$ & $\begin{array}{l}37.7 \\
38.9 \\
35.4 \\
33.0 \\
27.7\end{array}$ & $\begin{array}{l}9,697 \\
8,262 \\
8,084 \\
7,740 \\
7,314\end{array}$ & $\begin{array}{l}2,148 \\
1,963 \\
1,642 \\
1,563 \\
1,232\end{array}$ & $\begin{array}{l}22.5 \\
23.8 \\
20.3 \\
20.2 \\
16.8\end{array}$ & $\begin{array}{l}782 \\
596 \\
568 \\
582 \\
574\end{array}$ & $\begin{array}{l}173 \\
159 \\
146 \\
179 \\
154\end{array}$ & $\begin{array}{l}22.1 \\
26.6 \\
25.7 \\
30.8 \\
26.8\end{array}$ \\
\hline $\begin{array}{l}1978 \\
1977 \\
1976 \\
1975 \\
1974 \\
1973\end{array}$ & $\begin{array}{r}5,012 \\
5,028 \\
4,771 \\
\text { (NA) } \\
\text { (NA) } \\
\text { (NA) }\end{array}$ & $\begin{array}{r}1,384 \\
1,422 \\
1,443 \\
\text { (NA) } \\
\text { (NA) } \\
\text { (NA) }\end{array}$ & $\begin{array}{l}27.6 \\
28.3 \\
30.2 \\
\text { (NA) } \\
\text { (NA) } \\
\text { (NA) }\end{array}$ & $\begin{array}{l}4,972 \\
5,000 \\
4,736 \\
4,896 \\
4,939 \\
4,910\end{array}$ & $\begin{array}{l}1,354 \\
1,402 \\
1,424 \\
1,619 \\
1,414 \\
1,364\end{array}$ & $\begin{array}{l}27.2 \\
28.0 \\
30.1 \\
33.1 \\
28.6 \\
27.8\end{array}$ & $\begin{array}{r}6,527 \\
6,500 \\
6,034 \\
\text { (NA) } \\
\text { (NA) } \\
\text { (NA) }\end{array}$ & $\begin{array}{r}1,098 \\
1,164 \\
1,212 \\
\text { (NA) } \\
\text { (NA) } \\
\text { (NA) }\end{array}$ & $\begin{array}{l}16.8 \\
17.9 \\
20.1 \\
\text { (NA) } \\
\text { (NA) } \\
\text { (NA) }\end{array}$ & $\begin{array}{r}539 \\
518 \\
464 \\
\text { (NA) } \\
\text { (NA) } \\
\text { (NA) }\end{array}$ & $\begin{array}{r}125 \\
113 \\
128 \\
137 \\
117 \\
95\end{array}$ & $\begin{array}{l}23.2 \\
21.9 \\
27.7 \\
32.6 \\
28.9 \\
24.9\end{array}$ \\
\hline
\end{tabular}

\footnotetext{
(NA) Not available.
}

1 For 2004, figures are revised to reflect a correction to the weights in the 2005 ASEC.

2 Consistent with 2001 data through implementation of Census 2000-based population controls and a 28,000 household sample expansion.

${ }^{3}$ For 1999 , figures are based on Census 2000 population controls.

4 For 1992, figures are based on 1990 census population controls.

${ }^{5}$ For 1991, figures are revised to correct for nine omitted weights from the original March 1992 CPS file.

6 For 1988 and 1987, figures are based on new processing procedures and are also revised to reflect corrections to the files after publication of the 1988 advance report Money Income and Poverty Status in the United States: 1988, P-60, No. 166.

7 The 2003 CPS allowed respondents to choose more than one race. White alone refers to people who reported White and did not report any other race category. The use of this single-race population does not imply that it is the preferred method of presenting or analyzing data. The Census Bureau uses a variety of approaches. Information on people who reported more than one race, such as White and American Indian and Alaska Native or Asian and Black or African American, is available from Census 2000 through American FactFinder. About 2.6 percent of people reported more than one race in Census 2000.

8 For 2001 and earlier years, the CPS allowed respondents to report only one race group. The reference race groups for 2001 and earlier poverty data are White, non-Hispanic White, Black, and Asian and Pacific Islander.

9 Black alone refers to people who reported Black and did not report any other race.

10 Asian alone refers to people who reported Asian and did not report any other race.

Note: Prior to 1979, people in unrelated subfamilies were included in people in families. Beginning in 1979, people in unrelated subfamilies are included in all people but are excluded from people in families.

Source: U.S. Census Bureau, Current Population Survey, 1960 to 2006 Annual Social and Economic Supplements. 
Table B-3.

Poverty Status of Families by Type of Family: 1959 to 2005

(Numbers in thousands. Families as of March of the following year)

\begin{tabular}{|c|c|c|c|c|c|c|c|c|c|c|c|c|c|}
\hline \multirow{3}{*}{\multicolumn{2}{|c|}{$\begin{array}{l}\text { Race, Hispanic origin, } \\
\text { and year }\end{array}$}} & \multicolumn{3}{|c|}{ All families } & \multicolumn{3}{|c|}{ Married-couple families } & \multicolumn{3}{|c|}{$\begin{array}{l}\text { Male householder, } \\
\text { no wife present }\end{array}$} & \multicolumn{3}{|c|}{$\begin{array}{l}\text { Female householder, } \\
\text { no husband present }\end{array}$} \\
\hline & & \multirow[b]{2}{*}{ Total } & \multicolumn{2}{|c|}{ Below poverty } & \multirow[b]{2}{*}{ Total } & \multicolumn{2}{|c|}{ Below poverty } & \multirow[b]{2}{*}{ Total } & \multicolumn{2}{|c|}{ Below poverty } & \multirow[b]{2}{*}{ Total } & \multicolumn{2}{|c|}{ Below poverty } \\
\hline & & & Number & Percent & & Number & Percent & & Number & Percent & & Number & Percent \\
\hline \multicolumn{14}{|c|}{ ALL RACES } \\
\hline $\begin{array}{l}2005 \ldots \\
2004^{1} .\end{array}$ & & $\begin{array}{l}77,418 \\
76,866\end{array}$ & $\begin{array}{l}7,657 \\
7,835\end{array}$ & $\begin{array}{r}9.9 \\
10.2\end{array}$ & $\begin{array}{l}58,189 \\
57,983\end{array}$ & $\begin{array}{l}2,944 \\
3,216\end{array}$ & $\begin{array}{l}5.1 \\
5.5\end{array}$ & $\begin{array}{l}5,134 \\
4,901\end{array}$ & $\begin{array}{l}669 \\
657\end{array}$ & $\begin{array}{l}13.0 \\
13.4\end{array}$ & $\begin{array}{l}14,095 \\
13,981\end{array}$ & $\begin{array}{l}4,044 \\
3,962\end{array}$ & $\begin{array}{l}28.7 \\
28.3\end{array}$ \\
\hline $\begin{array}{l}2003 . \\
2002 . \\
2001 \\
2000^{2} . \\
1999^{3} .\end{array}$ & $\begin{array}{l}\ldots \ldots \ldots \\
\ldots \ldots \ldots \\
\ldots \ldots \ldots \\
\ldots \ldots \ldots \\
\ldots \ldots \ldots\end{array}$ & $\begin{array}{l}76,232 \\
75,616 \\
74,340 \\
73,778 \\
73,206\end{array}$ & $\begin{array}{l}7,607 \\
7,229 \\
6,813 \\
6,400 \\
6,792\end{array}$ & $\begin{array}{r}10.0 \\
9.6 \\
9.2 \\
8.7 \\
9.3\end{array}$ & \begin{tabular}{l|}
57,725 \\
57,327 \\
56,755 \\
56,598 \\
56,290
\end{tabular} & $\begin{array}{l}3,115 \\
3,052 \\
2,760 \\
2,637 \\
2,748\end{array}$ & $\begin{array}{l}5.4 \\
5.3 \\
4.9 \\
4.7 \\
4.9\end{array}$ & $\begin{array}{l}4,717 \\
4,663 \\
4,440 \\
4,277 \\
4,099\end{array}$ & $\begin{array}{l}636 \\
564 \\
583 \\
485 \\
485\end{array}$ & $\begin{array}{l}13.5 \\
12.1 \\
13.1 \\
11.3 \\
11.8\end{array}$ & $\begin{array}{l}13,791 \\
13,626 \\
13,146 \\
12,903 \\
12,818\end{array}$ & $\begin{array}{l}3,856 \\
3,613 \\
3,470 \\
3,278 \\
3,559\end{array}$ & $\begin{array}{l}28.0 \\
26.5 \\
26.4 \\
25.4 \\
27.8\end{array}$ \\
\hline $\begin{array}{l}1998 . \\
1997 . \\
1996 \\
1995 \\
1994 .\end{array}$. & $\ldots \ldots \ldots$ & $\begin{array}{l}71,551 \\
70,884 \\
70,241 \\
69,597 \\
69,313\end{array}$ & $\begin{array}{l}7,186 \\
7,324 \\
7,708 \\
7,532 \\
8,053\end{array}$ & $\begin{array}{l}10.0 \\
10.3 \\
11.0 \\
10.8 \\
11.6\end{array}$ & \begin{tabular}{l|}
54,778 \\
54,321 \\
53,604 \\
53,570 \\
53,865
\end{tabular} & $\begin{array}{l}2,879 \\
2,821 \\
3,010 \\
2,982 \\
3,272\end{array}$ & $\begin{array}{l}5.3 \\
5.2 \\
5.6 \\
5.6 \\
6.1\end{array}$ & $\begin{array}{l}3,977 \\
3,911 \\
3,847 \\
3,513 \\
3,228\end{array}$ & $\begin{array}{l}476 \\
507 \\
531 \\
493 \\
549\end{array}$ & $\begin{array}{l}12.0 \\
13.0 \\
13.8 \\
14.0 \\
17.0\end{array}$ & $\begin{array}{l}12,796 \\
12,652 \\
12,790 \\
12,514 \\
12,220\end{array}$ & $\begin{array}{l}3,831 \\
3,995 \\
4,167 \\
4,057 \\
4,232\end{array}$ & $\begin{array}{l}29.9 \\
31.6 \\
32.6 \\
32.4 \\
34.6\end{array}$ \\
\hline $\begin{array}{l}1993 . \\
1992^{4} \\
1991^{5} \\
1990 \\
1989 .\end{array}$ & $\begin{array}{l}\cdots \cdots \cdots \cdots \\
\cdots \cdots \cdots \cdots \cdots \\
\cdots \cdots \cdots \cdots\end{array}$ & $\begin{array}{l}68,506 \\
68,216 \\
67,175 \\
66,322 \\
66,090\end{array}$ & $\begin{array}{l}8,393 \\
8,144 \\
7,712 \\
7,098 \\
6,784\end{array}$ & \begin{tabular}{l|}
12.3 \\
11.9 \\
11.5 \\
10.7 \\
10.3
\end{tabular} & $\begin{array}{l}53,181 \\
53,090 \\
52,457 \\
52,147 \\
52,317\end{array}$ & $\begin{array}{l}3,481 \\
3,385 \\
3,158 \\
2,981 \\
2,931\end{array}$ & $\begin{array}{l}6.5 \\
6.4 \\
6.0 \\
5.7 \\
5.6\end{array}$ & $\begin{array}{l}2,914 \\
3,065 \\
3,025 \\
2,907 \\
2,884\end{array}$ & $\begin{array}{l}488 \\
484 \\
392 \\
349 \\
348\end{array}$ & $\begin{array}{l}16.8 \\
15.8 \\
13.0 \\
12.0 \\
12.1 \\
\end{array}$ & \begin{tabular}{r|}
12,411 \\
12,061 \\
11,693 \\
11,268 \\
10,890
\end{tabular} & $\begin{array}{l}4,424 \\
4,275 \\
4,161 \\
3,768 \\
3,504\end{array}$ & $\begin{array}{l}35.6 \\
35.4 \\
35.6 \\
33.4 \\
32.2\end{array}$ \\
\hline $\begin{array}{l}1988^{6} . \\
1987^{6} \\
1986 \\
1985 \\
1984 .\end{array}$. & $\begin{array}{l}\ldots \ldots \\
\ldots \ldots \ldots \\
\ldots \ldots \ldots\end{array}$ & $\begin{array}{l}65,837 \\
65,204 \\
64,491 \\
63,558 \\
62,706\end{array}$ & $\begin{array}{l}6,874 \\
7,005 \\
7,023 \\
7,223 \\
7,277\end{array}$ & $\begin{array}{l}10.4 \\
10.7 \\
10.9 \\
11.4 \\
11.6\end{array}$ & $\begin{array}{l}52,100 \\
51,675 \\
51,537 \\
50,933 \\
50,350\end{array}$ & $\begin{array}{l}2,897 \\
3,011 \\
3,123 \\
3,438 \\
3,488\end{array}$ & $\begin{array}{l}5.6 \\
5.8 \\
6.1 \\
6.7 \\
6.9\end{array}$ & $\begin{array}{l}2,847 \\
2,833 \\
2,510 \\
2,414 \\
2,228\end{array}$ & $\begin{array}{l}336 \\
340 \\
287 \\
311 \\
292\end{array}$ & $\begin{array}{l}11.8 \\
12.0 \\
11.4 \\
12.9 \\
13.1\end{array}$ & $\begin{array}{c}10,890 \\
10,696 \\
10,445 \\
10,211 \\
10,129\end{array}$ & $\begin{array}{l}3,642 \\
3,654 \\
3,613 \\
3,474 \\
3,498\end{array}$ & $\begin{array}{l}33.4 \\
34.2 \\
34.6 \\
34.0 \\
34.5\end{array}$ \\
\hline $\begin{array}{l}1983 . \\
1982 \\
1981 \\
1980 \\
1979 .\end{array}$. & $\begin{array}{l}\ldots \ldots \ldots \\
\ldots \ldots \ldots \\
\ldots \ldots \ldots \\
\ldots \ldots \ldots\end{array}$ & $\begin{array}{l}62,015 \\
61,393 \\
61,019 \\
60,309 \\
59,550\end{array}$ & $\begin{array}{l}7,647 \\
7,512 \\
6,851 \\
6,217 \\
5,461\end{array}$ & $\begin{array}{r}12.3 \\
12.2 \\
11.2 \\
10.3 \\
9.2\end{array}$ & $\begin{array}{l}50,081 \\
49,908 \\
49,630 \\
49,294 \\
49,112\end{array}$ & $\begin{array}{l}3,815 \\
3,789 \\
3,394 \\
3,032 \\
2,640\end{array}$ & $\begin{array}{l}7.6 \\
7.6 \\
6.8 \\
6.2 \\
5.4\end{array}$ & $\begin{array}{l}2,038 \\
2,016 \\
1,986 \\
1,933 \\
1,733\end{array}$ & \begin{tabular}{l|}
268 \\
290 \\
205 \\
213 \\
176
\end{tabular} & $\begin{array}{l}13.2 \\
14.4 \\
10.3 \\
11.0 \\
10.2\end{array}$ & $\begin{array}{l}9,896 \\
9,469 \\
9,403 \\
9,082 \\
8,705\end{array}$ & $\begin{array}{l}3,564 \\
3,434 \\
3,252 \\
2,972 \\
2,645\end{array}$ & $\begin{array}{l}36.0 \\
36.3 \\
34.6 \\
32.7 \\
30.4\end{array}$ \\
\hline $\begin{array}{l}1978 \\
1977 \\
1976 \\
1975 \\
1974 .\end{array}$. & 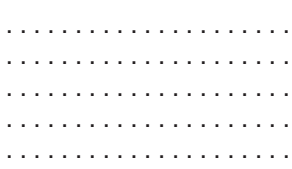 & $\begin{array}{l}57,804 \\
57,215 \\
56,710 \\
56,245 \\
55,698\end{array}$ & $\begin{array}{l}5,280 \\
5,311 \\
5,311 \\
5,450 \\
4,922\end{array}$ & $\begin{array}{l}9.1 \\
9.3 \\
9.4 \\
9.7 \\
8.8\end{array}$ & $\begin{array}{l}47,692 \\
47,385 \\
47,497 \\
47,318 \\
47,069\end{array}$ & $\begin{array}{l}2,474 \\
2,524 \\
2,606 \\
2,904 \\
2,474\end{array}$ & $\begin{array}{l}5.2 \\
5.3 \\
5.5 \\
6.1 \\
5.3\end{array}$ & $\begin{array}{l}1,654 \\
1,594 \\
1,500 \\
1,445 \\
1,399\end{array}$ & $\begin{array}{l}152 \\
177 \\
162 \\
116 \\
125\end{array}$ & $\begin{array}{r}9.2 \\
11.1 \\
10.8 \\
8.0 \\
8.9\end{array}$ & $\begin{array}{l}8,458 \\
8,236 \\
7,713 \\
7,482 \\
7,230\end{array}$ & $\begin{array}{l}2,654 \\
2,610 \\
2,543 \\
2,430 \\
2,324\end{array}$ & $\begin{array}{l}31.4 \\
31.7 \\
33.0 \\
32.5 \\
32.1\end{array}$ \\
\hline $\begin{array}{l}1973 . \\
1972 \\
1971 \\
1970 \\
1969 .\end{array}$. & 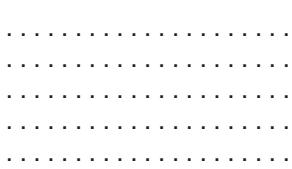 & $\begin{array}{l}55,053 \\
54,373 \\
53,296 \\
52,227 \\
51,586\end{array}$ & $\begin{array}{l}4,828 \\
5,075 \\
5,303 \\
5,260 \\
5,008\end{array}$ & $\begin{array}{r}8.8 \\
9.3 \\
10.0 \\
10.1 \\
9.7\end{array}$ & $\begin{array}{l}46,812 \\
46,314 \\
45,752 \\
44,739 \\
44,436\end{array}$ & $\begin{array}{r}2,482 \\
(\mathrm{NA}) \\
(\mathrm{NA}) \\
(\mathrm{NA}) \\
(\mathrm{NA})\end{array}$ & $\begin{array}{r}5.3 \\
(\mathrm{NA}) \\
(\mathrm{NA}) \\
(\mathrm{NA}) \\
(\mathrm{NA})\end{array}$ & $\begin{array}{l}1,438 \\
1,452 \\
1,353 \\
1,487 \\
1,559\end{array}$ & $\begin{array}{r}154 \\
\text { (NA) } \\
\text { (NA) } \\
\text { (NA) } \\
\text { (NA) }\end{array}$ & $\begin{array}{l}10.7 \\
\text { (NA) } \\
\text { (NA) } \\
\text { (NA) } \\
\text { (NA) }\end{array}$ & $\begin{array}{l}6,804 \\
6,607 \\
6,191 \\
6,001 \\
5,591\end{array}$ & $\begin{array}{l}2,193 \\
2,158 \\
2,100 \\
1,952 \\
1,827\end{array}$ & $\begin{array}{l}32.2 \\
32.7 \\
33.9 \\
32.5 \\
32.7\end{array}$ \\
\hline $\begin{array}{l}1968 . \\
1967 \\
1966 \\
1965 \\
1964 .\end{array}$ & $\ldots$ & $\begin{array}{l}50,511 \\
49,835 \\
48,921 \\
48,278 \\
47,836\end{array}$ & $\begin{array}{l}5,047 \\
5,667 \\
5,784 \\
6,721 \\
7,160\end{array}$ & $\begin{array}{l}10.0 \\
11.4 \\
11.8 \\
13.9 \\
15.0\end{array}$ & $\begin{array}{l}43,842 \\
43,292 \\
42,553 \\
42,107 \\
41,648\end{array}$ & $\begin{array}{l}\text { (NA) } \\
(\mathrm{NA}) \\
(\mathrm{NA}) \\
(\mathrm{NA}) \\
(\mathrm{NA})\end{array}$ & $\begin{array}{l}\text { (NA) } \\
\text { (NA) } \\
\text { (NA) } \\
\text { (NA) } \\
\text { (NA) }\end{array}$ & $\begin{array}{l}1,228 \\
1,210 \\
1,197 \\
1,179 \\
1,182\end{array}$ & $\begin{array}{l}\text { (NA) } \\
\text { (NA) } \\
\text { (NA) } \\
\text { (NA) } \\
\text { (NA) }\end{array}$ & $\begin{array}{l}\text { (NA) } \\
\text { (NA) } \\
\text { (NA) } \\
\text { (NA) } \\
\text { (NA) }\end{array}$ & $\begin{array}{l}5,441 \\
5,333 \\
5,171 \\
4,992 \\
5,006\end{array}$ & $\begin{array}{l}1,755 \\
1,774 \\
1,721 \\
1,916 \\
1,822\end{array}$ & $\begin{array}{l}32.3 \\
33.3 \\
33.1 \\
38.4 \\
36.4\end{array}$ \\
\hline $\begin{array}{l}1963 . \\
1962 \\
1961 \\
1960 \\
1959 .\end{array}$. & 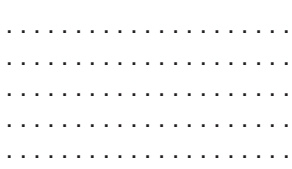 & $\begin{array}{l}47,436 \\
46,998 \\
46,341 \\
45,435 \\
45,054\end{array}$ & $\begin{array}{l}7,554 \\
8,077 \\
8,391 \\
8,243 \\
8,320\end{array}$ & $\begin{array}{l}15.9 \\
17.2 \\
18.1 \\
18.1 \\
18.5\end{array}$ & $\begin{array}{l}41,311 \\
40,923 \\
40,405 \\
39,624 \\
39,335\end{array}$ & $\begin{array}{l}\text { (NA) } \\
\text { (NA) } \\
\text { (NA) } \\
\text { (NA) } \\
\text { (NA) }\end{array}$ & $\begin{array}{l}\text { (NA) } \\
\text { (NA) } \\
\text { (NA) } \\
\text { (NA) } \\
\text { (NA) }\end{array}$ & $\begin{array}{l}1,243 \\
1,334 \\
1,293 \\
1,202 \\
1,226\end{array}$ & $\begin{array}{l}\text { (NA) } \\
\text { (NA) } \\
\text { (NA) } \\
\text { (NA) } \\
\text { (NA) }\end{array}$ & $\begin{array}{l}\text { (NA) } \\
\text { (NA) } \\
\text { (NA) } \\
\text { (NA) } \\
\text { (NA) }\end{array}$ & $\begin{array}{l}4,882 \\
4,741 \\
4,643 \\
4,609 \\
4,493\end{array}$ & $\begin{array}{l}1,972 \\
2,034 \\
1,954 \\
1,955 \\
1,916\end{array}$ & $\begin{array}{l}40.4 \\
42.9 \\
42.1 \\
42.4 \\
42.6\end{array}$ \\
\hline
\end{tabular}

(NA) Not available.

1 For 2004, figures are revised to reflect a correction to the weights in the 2005 ASEC.

2 Consistent with 2001 data through implementation of Census 2000-based population controls and a 28,000 household sample expansion.

3 For 1999 , figures are based on Census 2000 population controls.

${ }^{4}$ For 1992, figures are based on 1990 census population controls.

5 For 1991, figures are revised to correct for nine omitted weights from the original March 1992 CPS file.

${ }^{6}$ For 1988 and 1987, figures are based on new processing procedures and are also revised to reflect corrections to the files after publication of the 1988 advance report Money Income and Poverty Status in the United States: 1988, P-60, No. 166.

Note: Before 1979, unrelated subfamilies were included in all families. Beginning in 1979, unrelated subfamilies are excluded from all families.

Source: U.S. Census Bureau, Current Population Survey, 1960 to 2006 Annual Social and Economic Supplements. 


\section{APPENDIX C. ESTIMATES OF HEALTH INSURANCE COVERAGE}

\section{Quality of Health Insurance Coverage Estimates}

National surveys and health insurance coverage. Health insurance coverage is likely to be underreported on the Current Population Survey (CPS). While underreporting affects most, if not all, surveys, underreporting of health insurance coverage on the Annual Social and Economic Supplement (ASEC) appears to be a larger problem than in other national surveys that ask about insurance. Some reasons for the disparity may include the fact that income, not health insurance, is the main focus of the ASEC questionnaire. In addition, the ASEC collects health insurance information by asking in February through April about the previous year's coverage. Asking annual retrospective questions appears to be less of a problem when collecting income data (possibly because the interview period is close to when people pay their taxes), but it may be less than ideal when asking about health insurance coverage. Compared with other national surveys, the CPS estimate of the number of people without health insurance more closely approximates the number of people who are uninsured at a specific point in time during the year than the number of people uninsured for the entire year. For a comparison of health insurance coverage rates from the major federal surveys, see How Many People Lack Insurance and For How Long? (Congressional Budget Office, May 2003).

Reporting of coverage through major federal health insurance programs. The CPS ASEC data underreport Medicare and Medicaid coverage compared with enrollment and participation data from the Centers for Medicare and Medicaid Services (CMS). ' Because the CPS is largely a labor force survey, interviewers receive less training on health insurance concepts than labor concepts. Additionally, many people may not be aware that a health insurance program covers them or their children if they have not used covered services recently. CMS data, on the other hand, represent the actual number of people who have enrolled or participated in these programs.

Changes in Medicaid coverage estimates from one year to the next

' CMS is the federal agency primarily responsible for administering the Medicare and Medicaid programs at the national level. should be viewed with caution. Because many people who are covered by Medicaid do not report that coverage, the U.S. Census Bureau assigns coverage to those who are generally regarded as "categorically eligible" (those who received some other benefits, usually public assistance payments, that make them eligible for Medicaid). Since the number of people receiving public assistance has been dropping, the relationship between Medicaid coverage and public assistance has changed, causing the imputation process to introduce a downward bias in the most recent Medicaid estimates.

After consulting with health insurance experts, the Census Bureau modified the definition of the population without health insurance in the supplement to the March 1998 CPS, which collected data about coverage in 1997. Previously, people with no coverage other than access to the Indian Health Service were counted as part of the insured population.

Subsequently, the Census Bureau has counted these people as uninsured. The effect of this change on the overall estimates of health insurance coverage was negligible. 
Table C-1.

Health Insurance Coverage by Race and Hispanic Origin: 1987 to 2005

(Numbers in thousands. People as of March of the following year)

\begin{tabular}{|c|c|c|c|c|c|c|c|c|c|c|}
\hline \multirow{3}{*}{$\begin{array}{c}\text { Race, Hispanic origin, } \\
\text { and year }\end{array}$} & \multirow[b]{3}{*}{$\begin{array}{r}\text { Total } \\
\text { people }\end{array}$} & \multicolumn{8}{|c|}{ Covered by private and/or government health insurance } & \multirow[b]{3}{*}{$\begin{array}{r}\text { No } \\
\text { covered }\end{array}$} \\
\hline & & & \multicolumn{3}{|c|}{ Private health insurance } & \multicolumn{4}{|c|}{ Government health insurance } & \\
\hline & & Total & Total & $\begin{array}{r}\text { Employ- } \\
\text { ment } \\
\text { based }\end{array}$ & $\begin{array}{r}\text { Direct } \\
\text { purchase }\end{array}$ & Total & Medicaid & Medicare & $\begin{array}{r}\text { Military } \\
\text { health } \\
\text { care }^{1}\end{array}$ & \\
\hline \multicolumn{11}{|l|}{ ALL RACES } \\
\hline \multicolumn{11}{|l|}{ Numbers } \\
\hline 2005. & 293,834 & 247,257 & 198,901 & 174,819 & 26,781 & 80,249 & 38,134 & 40,185 & 11,172 & 46,577 \\
\hline $2004^{2}$ & 291,166 & 245,860 & 198,658 & 174,186 & 27,193 & 79,392 & 37,963 & 39,708 & 10,660 & 45,306 \\
\hline 2004 & 291,155 & 245,335 & 198,262 & 174,174 & 26,961 & 79,086 & 37,514 & 39,745 & 10,680 & 45,820 \\
\hline 2003 & 288,280 & 243,320 & 197,869 & 174,020 & 26,486 & 76,755 & 35,647 & 39,456 & 9,979 & 44,961 \\
\hline 2002 & 285,933 & 242,360 & 198,973 & 175,296 & 26,639 & 73,624 & 33,246 & 38,448 & 10,063 & 43,574 \\
\hline 2001 & 282,082 & 240,875 & 199,860 & 176,551 & 26,057 & 71,295 & 31,601 & 38,043 & 9,552 & 41,207 \\
\hline $2000^{3}$ & 279,517 & 239,714 & 201,060 & 177,848 & 26,524 & 69,037 & 29,533 & 37,740 & 9,099 & 39,804 \\
\hline $1999^{4}$. & 276,804 & 236,576 & 198,841 & 175,101 & 27,415 & 67,683 & 28,506 & 36,923 & 8,648 & 40,228 \\
\hline 1999 & 274,087 & 231,533 & 194,599 & 172,023 & 26,179 & 66,176 & 27,890 & 36,066 & 8,530 & 42,554 \\
\hline 1998 & 271,743 & 227,462 & 190,861 & 168,576 & 25,948 & 66,087 & 27,854 & 35,887 & 8,747 & 44,281 \\
\hline $1997^{5}$. & 269,094 & 225,646 & 188,532 & 165,091 & 27,158 & 66,685 & 28,956 & 35,590 & 8,527 & 43,448 \\
\hline 1996. & 266,792 & 225,077 & 187,395 & 163,221 & 28,335 & 69,000 & 31,451 & 35,227 & 8,712 & 41,716 \\
\hline 1995 & 264,314 & 223,733 & 185,881 & 161,453 & 30,188 & 69,776 & 31,877 & 34,655 & 9,375 & 40,582 \\
\hline $1994^{6}$ & 262,105 & 222,387 & 184,318 & 159,634 & 31,349 & 70,163 & 31,645 & 33,901 & 11,165 & 39,718 \\
\hline $1993^{7}$ & 259,753 & 220,040 & 182,351 & 148,318 & (NA) & 68,554 & 31,749 & 33,097 & 9,560 & 39,713 \\
\hline $1992^{8}$ & 256,830 & 218,189 & 181,466 & 148,796 & (NA) & 66,244 & 29,416 & 33,230 & 9,510 & 38,641 \\
\hline $1991 \ldots$ & 251,447 & 216,003 & 181,375 & 150,077 & (NA) & 63,882 & 26,880 & 32,907 & 9,820 & 35,445 \\
\hline $1990 \ldots$ & 248,886 & 214,167 & 182,135 & 150,215 & (NA) & 60,965 & 24,261 & 32,260 & 9,922 & 34,719 \\
\hline 1989 & 246,191 & 212,807 & 183,610 & 151,644 & (NA) & 57,382 & 21,185 & 31,495 & 9,870 & 33,385 \\
\hline 1988 & 243,685 & 211,005 & 182,019 & 150,940 & (NA) & 56,850 & 20,728 & 30,925 & 10,105 & 32,680 \\
\hline $1987^{9}$ & 241,187 & 210,161 & 182,160 & 149,739 & (NA) & 56,282 & 20,211 & 30,458 & 10,542 & 31,026 \\
\hline \multicolumn{11}{|l|}{ Percents } \\
\hline 2005 & 100.0 & 84.1 & 67.7 & 59.5 & 9.1 & 27.3 & 13.0 & 13.7 & 3.8 & 15.9 \\
\hline $2004^{2}$ & 100.0 & 84.4 & 68.2 & 59.8 & 9.3 & 27.3 & 13.0 & 13.6 & 3.7 & 15.6 \\
\hline 2004 & 100.0 & 84.3 & 68.1 & 59.8 & 9.3 & 27.2 & 12.9 & 13.7 & 3.7 & 15.7 \\
\hline 2003. & 100.0 & 84.4 & 68.6 & 60.4 & 9.2 & 26.6 & 12.4 & 13.7 & 3.5 & 15.6 \\
\hline 2002 & 100.0 & 84.8 & 69.6 & 61.3 & 9.3 & 25.7 & 11.6 & 13.4 & 3.5 & 15.2 \\
\hline 2001 & 100.0 & 85.4 & 70.9 & 62.6 & 9.2 & 25.3 & 11.2 & 13.5 & 3.4 & 14.6 \\
\hline $2000^{3}$ & 100.0 & 85.8 & 71.9 & 63.6 & 9.5 & 24.7 & 10.6 & 13.5 & 3.3 & 14.2 \\
\hline $1999^{4}$ & 100.0 & 85.5 & 71.8 & 63.3 & 9.9 & 24.5 & 10.3 & 13.3 & 3.1 & 14.5 \\
\hline 1999 & 100.0 & 84.5 & 71.0 & 62.8 & 9.6 & 24.1 & 10.2 & 13.2 & 3.1 & 15.5 \\
\hline 1998 & 100.0 & 83.7 & 70.2 & 62.0 & 9.5 & 24.3 & 10.3 & 13.2 & 3.2 & 16.3 \\
\hline $1997^{5}$ & 100.0 & 83.9 & 70.1 & 61.4 & 10.1 & 24.8 & 10.8 & 13.2 & 3.2 & 16.1 \\
\hline 1996 & 100.0 & 84.4 & 70.2 & 61.2 & 10.6 & 25.9 & 11.8 & 13.2 & 3.3 & 15.6 \\
\hline 1995 & 100.0 & 84.6 & 70.3 & 61.1 & 11.4 & 26.4 & 12.1 & 13.1 & 3.5 & 15.4 \\
\hline $1994^{6}$ & 100.0 & 84.8 & 70.3 & 60.9 & 12.0 & 26.8 & 12.1 & 12.9 & 4.3 & 15.2 \\
\hline $1993^{7}$ & 100.0 & 84.7 & 70.2 & 57.1 & (NA) & 26.4 & 12.2 & 12.7 & 3.7 & 15.3 \\
\hline $1992^{8}$ & 100.0 & 85.0 & 70.7 & 57.9 & (NA) & 25.8 & 11.5 & 12.9 & 3.7 & 15.0 \\
\hline 1991 & 100.0 & 85.9 & 72.1 & 59.7 & (NA) & 25.4 & 10.7 & 13.1 & 3.9 & 14.1 \\
\hline 1990 & 100.0 & 86.1 & 73.2 & 60.4 & (NA) & 24.5 & 9.7 & 13.0 & 4.0 & 13.9 \\
\hline 1989 & 100.0 & 86.4 & 74.6 & 61.6 & (NA) & 23.3 & 8.6 & 12.8 & 4.0 & 13.6 \\
\hline 1988 & 100.0 & 86.6 & 74.7 & 61.9 & (NA) & 23.3 & 8.5 & 12.7 & 4.1 & 13.4 \\
\hline $1987^{9}$ & 100.0 & 87.1 & 75.5 & 62.1 & (NA) & 23.3 & 8.4 & 12.6 & 4.4 & 12.9 \\
\hline
\end{tabular}

See footnotes at end of table. 
Table C-1.

Health Insurance Coverage by Race and Hispanic Origin: 1987 to 2005-Con.

(Numbers in thousands. People as of March of the following year)

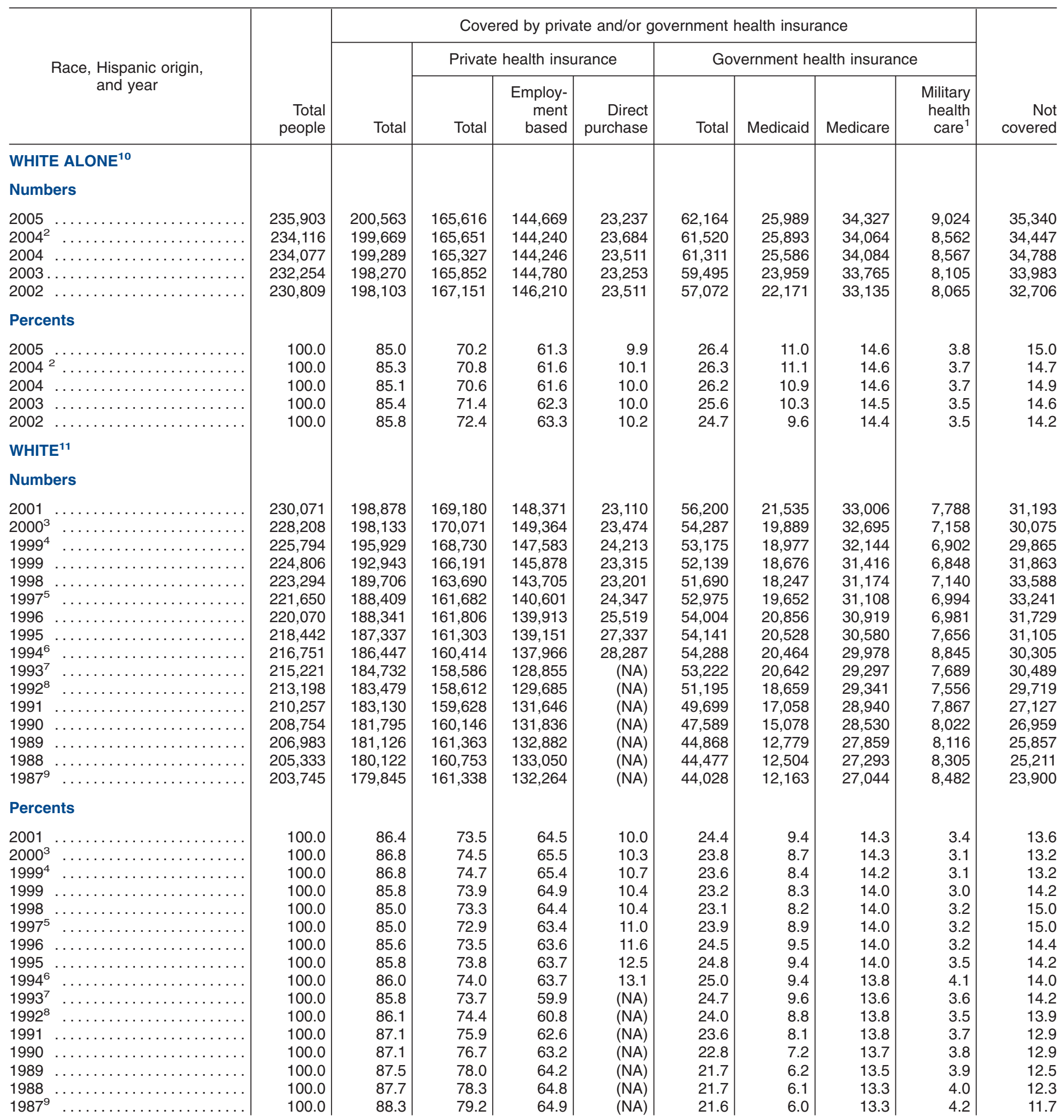


Table C-1.

Health Insurance Coverage by Race and Hispanic Origin: 1987 to 2005-Con.

(Numbers in thousands. People as of March of the following year)

\begin{tabular}{|c|c|c|c|c|c|c|c|c|c|c|}
\hline \multirow{3}{*}{$\begin{array}{l}\text { Race, Hispanic origin, } \\
\text { and year }\end{array}$} & \multirow[b]{3}{*}{$\begin{array}{r}\text { Total } \\
\text { people }\end{array}$} & \multicolumn{8}{|c|}{ Covered by private and/or government health insurance } & \multirow[b]{3}{*}{$\begin{array}{r}\text { Not } \\
\text { covered }\end{array}$} \\
\hline & & & \multicolumn{3}{|c|}{ Private health insurance } & \multicolumn{4}{|c|}{ Government health insurance } & \\
\hline & & Total & Total & $\begin{array}{r}\text { Employ- } \\
\text { ment } \\
\text { based }\end{array}$ & $\begin{array}{r}\text { Direct } \\
\text { purchase }\end{array}$ & Total & Medicaid & Medicare & $\begin{array}{r}\text { Military } \\
\text { health } \\
\text { care }^{1}\end{array}$ & \\
\hline \multicolumn{11}{|l|}{ WHITE ALONE, NOT HISPANIC } \\
\hline \multicolumn{11}{|l|}{ Numbers } \\
\hline 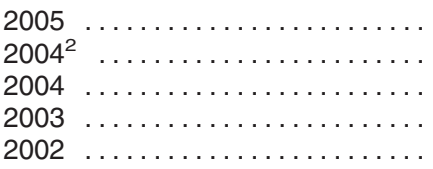 & $\begin{array}{l}195,893 \\
195,347 \\
195,301 \\
194,877 \\
194,421\end{array}$ & $\begin{array}{l}173,748 \\
173,541 \\
173,319 \\
173,295 \\
173,639\end{array}$ & $\begin{array}{l}147,974 \\
148,264 \\
148,069 \\
149,084 \\
150,422\end{array}$ & $\begin{array}{l}128,539 \\
128,308 \\
128,368 \\
129,261 \\
130,801\end{array}$ & $\begin{array}{l}21,523 \\
22,056 \\
21,944 \\
21,865 \\
22,128\end{array}$ & $\begin{array}{l}51,215 \\
50,951 \\
50,806 \\
49,743 \\
47,736\end{array}$ & $\begin{array}{l}17,418 \\
17,468 \\
17,241 \\
16,247 \\
14,984\end{array}$ & $\begin{array}{l}31,718 \\
31,627 \\
31,640 \\
31,458 \\
30,718\end{array}$ & $\begin{array}{l}8,279 \\
7,943 \\
7,952 \\
7,563 \\
7,465\end{array}$ & $\begin{array}{l}22,144 \\
21,807 \\
21,983 \\
21,582 \\
20,782\end{array}$ \\
\hline \multicolumn{11}{|l|}{ Percents } \\
\hline 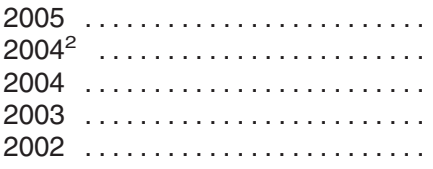 & $\begin{array}{l}100.0 \\
100.0 \\
100.0 \\
100.0 \\
100.0\end{array}$ & $\begin{array}{l}88.7 \\
88.8 \\
88.7 \\
88.9 \\
89.3\end{array}$ & $\begin{array}{l}75.5 \\
75.9 \\
75.8 \\
76.5 \\
77.4\end{array}$ & $\begin{array}{l}65.6 \\
65.7 \\
65.7 \\
66.3 \\
67.3\end{array}$ & $\begin{array}{l}11.0 \\
11.3 \\
11.2 \\
11.2 \\
11.4\end{array}$ & $\begin{array}{l}26.1 \\
26.1 \\
26.0 \\
25.5 \\
24.6\end{array}$ & $\begin{array}{l}8.9 \\
8.9 \\
8.8 \\
8.3 \\
7.7\end{array}$ & $\begin{array}{l}16.2 \\
16.2 \\
16.2 \\
16.1 \\
15.8\end{array}$ & $\begin{array}{l}4.2 \\
4.1 \\
4.1 \\
3.9 \\
3.8\end{array}$ & $\begin{array}{l}11.3 \\
11.2 \\
11.3 \\
11.1 \\
10.7\end{array}$ \\
\hline \multicolumn{11}{|l|}{ WHITE, NOT HISPANIC } \\
\hline 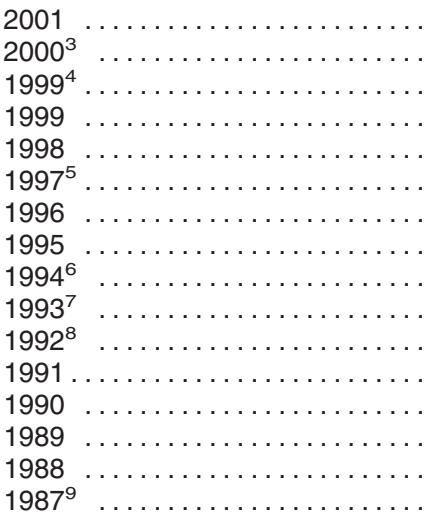 & $\begin{array}{l}194,822 \\
193,931 \\
192,858 \\
193,633 \\
193,074 \\
192,178 \\
191,791 \\
191,271 \\
192,771 \\
191,087 \\
189,113 \\
189,216 \\
188,240 \\
187,078 \\
186,047 \\
185,044\end{array}$ & $\begin{array}{l}175,412 \\
175,247 \\
173,958 \\
172,271 \\
170,184 \\
169,043 \\
169,699 \\
169,272 \\
170,541 \\
168,306 \\
167,394 \\
168,810 \\
168,015 \\
167,889 \\
167,048 \\
166,922\end{array}$ & $\begin{array}{l}152,821 \\
153,816 \\
152,984 \\
151,539 \\
149,910 \\
148,426 \\
149,262 \\
149,686 \\
150,181 \\
147,729 \\
147,967 \\
149,798 \\
150,306 \\
151,424 \\
151,009 \\
151,817\end{array}$ & $\begin{array}{l}133,295 \\
134,253 \\
133,123 \\
132,381 \\
130,956 \\
128,280 \\
128,355 \\
128,378 \\
128,633 \\
119,861 \\
120,482 \\
123,109 \\
123,261 \\
124,311 \\
124,622 \\
124,068\end{array}$ & $\begin{array}{r}21,796 \\
22,242 \\
22,882 \\
22,104 \\
22,110 \\
23,349 \\
24,456 \\
26,363 \\
27,205 \\
\text { (NA) } \\
\text { (NA) } \\
\text { (NA) } \\
\text { (NA) } \\
\text { (NA) } \\
\text { (NA) } \\
\text { (NA) }\end{array}$ & $\begin{array}{l}47,661 \\
46,297 \\
45,540 \\
44,749 \\
44,699 \\
45,691 \\
46,772 \\
46,501 \\
47,475 \\
46,158 \\
44,649 \\
44,228 \\
42,732 \\
40,624 \\
40,259 \\
39,792\end{array}$ & $\begin{array}{r}15,035 \\
13,788 \\
13,157 \\
13,120 \\
12,985 \\
14,046 \\
15,082 \\
14,381 \\
15,052 \\
14,980 \\
13,390 \\
12,750 \\
11,423 \\
9,759 \\
9,522 \\
9,143\end{array}$ & $\begin{array}{l}30,811 \\
30,642 \\
30,256 \\
29,457 \\
29,222 \\
29,213 \\
29,211 \\
28,918 \\
28,467 \\
27,795 \\
27,853 \\
27,695 \\
27,313 \\
26,738 \\
26,224 \\
26,054\end{array}$ & $\begin{array}{l}7,144 \\
6,564 \\
6,326 \\
6,306 \\
6,675 \\
6,504 \\
6,537 \\
7,163 \\
8,318 \\
7,243 \\
7,104 \\
7,402 \\
7,528 \\
7,567 \\
7,743 \\
7,883\end{array}$ & $\begin{array}{l}19,409 \\
18,683 \\
18,901 \\
21,363 \\
22,890 \\
23,135 \\
22,092 \\
21,999 \\
22,230 \\
22,781 \\
21,719 \\
20,406 \\
20,224 \\
19,188 \\
19,000 \\
18,122\end{array}$ \\
\hline \multicolumn{11}{|l|}{ Percents } \\
\hline 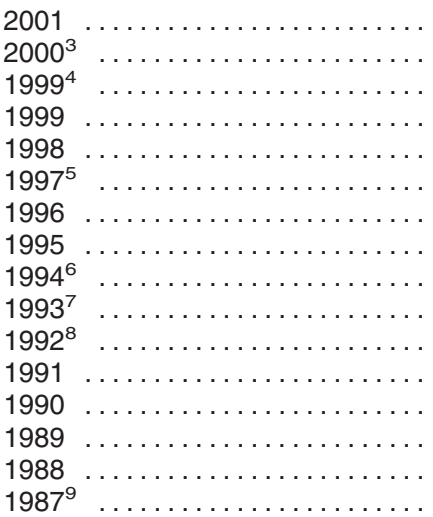 & $\begin{array}{l}100.0 \\
100.0 \\
100.0 \\
100.0 \\
100.0 \\
100.0 \\
100.0 \\
100.0 \\
100.0 \\
100.0 \\
100.0 \\
100.0 \\
100.0 \\
100.0 \\
100.0 \\
100.0\end{array}$ & $\begin{array}{l}90.0 \\
90.4 \\
90.2 \\
89.0 \\
88.1 \\
88.0 \\
88.5 \\
88.5 \\
88.5 \\
88.1 \\
88.5 \\
89.2 \\
89.3 \\
89.7 \\
89.8 \\
90.2\end{array}$ & $\begin{array}{l}78.4 \\
79.3 \\
79.3 \\
78.3 \\
77.6 \\
77.2 \\
77.8 \\
78.3 \\
77.9 \\
77.3 \\
78.2 \\
79.2 \\
79.8 \\
80.9 \\
81.2 \\
82.0\end{array}$ & $\begin{array}{l}68.4 \\
69.2 \\
69.0 \\
68.4 \\
67.8 \\
66.8 \\
66.9 \\
67.1 \\
66.7 \\
62.7 \\
63.7 \\
65.1 \\
65.5 \\
66.4 \\
67.0 \\
67.0\end{array}$ & $\begin{array}{l}11.2 \\
11.5 \\
11.9 \\
11.4 \\
11.5 \\
12.1 \\
12.8 \\
13.8 \\
14.1 \\
\text { (NA) } \\
\text { (NA) } \\
\text { (NA) } \\
\text { (NA) } \\
\text { (NA) } \\
\text { (NA) } \\
\text { (NA) }\end{array}$ & $\begin{array}{l}24.5 \\
23.9 \\
23.6 \\
23.1 \\
23.2 \\
23.8 \\
24.4 \\
24.3 \\
24.6 \\
24.2 \\
23.6 \\
23.4 \\
22.7 \\
21.7 \\
21.6 \\
21.5\end{array}$ & $\begin{array}{l}7.7 \\
7.1 \\
6.8 \\
6.8 \\
6.7 \\
7.3 \\
7.9 \\
7.5 \\
7.8 \\
7.8 \\
7.1 \\
6.7 \\
6.1 \\
5.2 \\
5.1 \\
4.9\end{array}$ & $\begin{array}{l}15.8 \\
15.8 \\
15.7 \\
15.2 \\
15.1 \\
15.2 \\
15.2 \\
15.1 \\
14.8 \\
14.5 \\
14.7 \\
14.6 \\
14.5 \\
14.3 \\
14.1 \\
14.1\end{array}$ & $\begin{array}{l}3.7 \\
3.4 \\
3.3 \\
3.3 \\
3.5 \\
3.4 \\
3.4 \\
3.7 \\
4.3 \\
3.8 \\
3.8 \\
3.9 \\
4.0 \\
4.0 \\
4.2 \\
4.3\end{array}$ & $\begin{array}{r}10.0 \\
9.6 \\
9.8 \\
11.0 \\
11.9 \\
12.0 \\
11.5 \\
11.5 \\
11.5 \\
11.9 \\
11.5 \\
10.8 \\
10.7 \\
10.3 \\
10.2 \\
9.8\end{array}$ \\
\hline
\end{tabular}

See footnotes at end of table. 
Table C-1.

Health Insurance Coverage by Race and Hispanic Origin: 1987 to 2005-Con.

(Numbers in thousands. People as of March of the following year)

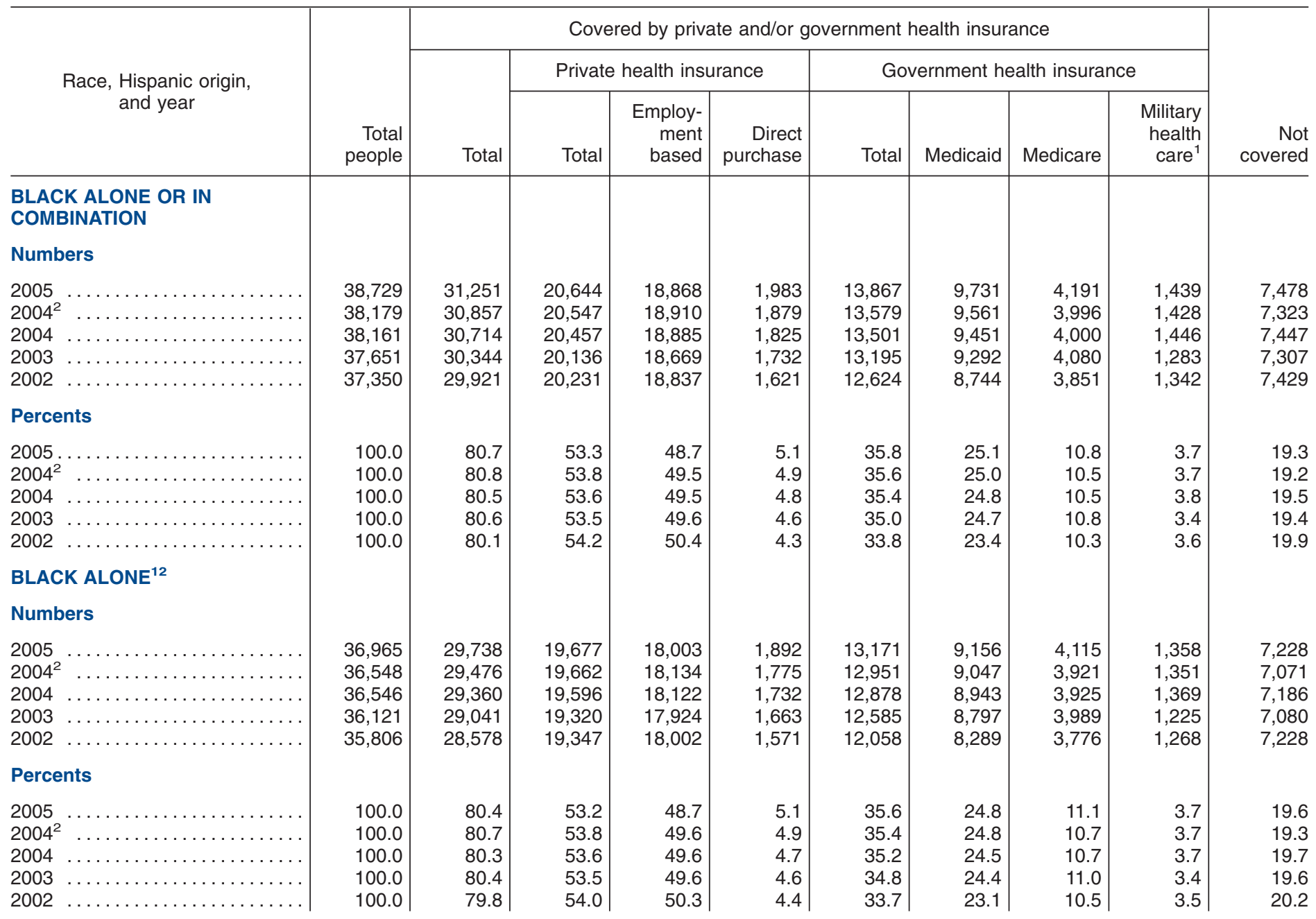

See footnotes at end of table. 
Table C-1.

Health Insurance Coverage by Race and Hispanic Origin: 1987 to 2005-Con.

(Numbers in thousands. People as of March of the following year)

\begin{tabular}{|c|c|c|c|c|c|c|c|c|c|c|}
\hline \multirow{3}{*}{$\begin{array}{l}\text { Race, Hispanic origin, } \\
\text { and year }\end{array}$} & \multirow[b]{3}{*}{$\begin{array}{r}\text { Total } \\
\text { people }\end{array}$} & \multicolumn{8}{|c|}{ Covered by private and/or government health insurance } & \multirow[b]{3}{*}{$\begin{array}{r}\text { Not } \\
\text { covered }\end{array}$} \\
\hline & & & \multicolumn{3}{|c|}{ Private health insurance } & \multicolumn{4}{|c|}{ Government health insurance } & \\
\hline & & Total & Total & $\begin{array}{r}\text { Employ- } \\
\text { ment } \\
\text { based }\end{array}$ & $\begin{array}{r}\text { Direct } \\
\text { purchase }\end{array}$ & Total & Medicaid & Medicare & $\begin{array}{r}\text { Military } \\
\text { health } \\
\text { care }^{1}\end{array}$ & \\
\hline \multicolumn{11}{|l|}{ BLACK $^{11}$} \\
\hline \multicolumn{11}{|l|}{ Numbers } \\
\hline 2001 & 36,023 & 29,190 & 20,363 & 18,975 & 1,696 & 11,616 & 7,994 & 3,783 & 1,192 & 6,833 \\
\hline $2000^{3}$ & 35,597 & 28,915 & 20,485 & 18,922 & 1,893 & 11,579 & 7,735 & 3,871 & 1,372 & 6,683 \\
\hline $1999^{4} \ldots$ & 35,893 & 28,775 & 20,442 & 18,854 & 2,065 & 11,361 & 7,652 & 3,615 & 1,216 & 7,119 \\
\hline 1999 & 35,509 & 27,973 & 19,805 & 18,363 & 1,912 & 11,165 & 7,495 & 3,588 & 1,198 & 7,536 \\
\hline 1998 & 35,070 & 27,274 & 18,663 & 17,132 & 1,782 & 11,524 & 7,903 & 3,703 & 1,111 & 7,797 \\
\hline $1997^{5}$ & 34,598 & 27,166 & 18,544 & 17,077 & 1,841 & 11,157 & 7,750 & 3,573 & 1,100 & 7,432 \\
\hline $1996 \ldots$ & 34,218 & 26,799 & 17,718 & 16,358 & 1,745 & 12,074 & 8,572 & 3,393 & 1,357 & 7,419 \\
\hline 1995 & 33,889 & 26,781 & 17,106 & 15,683 & 1,815 & 12,465 & 9,184 & 3,316 & 1,171 & 7,108 \\
\hline $1994^{6}$ & 33,531 & 26,928 & 17,147 & 15,607 & 2,147 & 12,693 & 9,007 & 3,167 & 1,683 & 6,603 \\
\hline $1993^{7}$ & 33,040 & 26,279 & 16,590 & 13,693 & (NA) & 12,588 & 9,283 & 3,072 & 1,331 & 6,761 \\
\hline $1992^{8}$ & 32,535 & 25,967 & 15,994 & 13,545 & (NA) & 12,464 & 9,122 & 3,154 & 1,459 & 6,567 \\
\hline $1991 \ldots \ldots \ldots \ldots$ & 31,439 & 24,932 & 15,466 & 13,297 & (NA) & 11,776 & 8,352 & 3,248 & 1,482 & 6,507 \\
\hline $1990 \ldots \ldots \ldots \ldots \ldots \ldots \ldots \ldots$ & 30,895 & 24,802 & 15,957 & 13,560 & (NA) & 11,150 & 7,809 & 3,106 & 1,402 & 6,093 \\
\hline $1989 \ldots \ldots \ldots \ldots$ & 30,392 & 24,550 & 16,520 & 14,187 & (NA) & 10,443 & 7,123 & 3,043 & 1,340 & 5,843 \\
\hline 1988 & 29,904 & 24,029 & 15,818 & 13,418 & (NA) & 10,415 & 7,049 & 3,064 & 1,385 & 5,875 \\
\hline $1987^{9}$ & 29,417 & 23,555 & 15,358 & 13,055 & (NA) & 10,380 & 7,046 & 2,918 & 1,497 & 5,862 \\
\hline \multicolumn{11}{|l|}{ Percents } \\
\hline $2001 \ldots$ & 100.0 & 81.0 & 56.5 & 52.7 & 4.7 & 32.2 & 22.2 & 10.5 & 3.3 & 19.0 \\
\hline $2000^{3}$ & 100.0 & 81.2 & 57.5 & 53.2 & 5.3 & 32.5 & 21.7 & 10.9 & 3.9 & 18.8 \\
\hline $1999^{4}$ & 100.0 & 80.2 & 57.0 & 52.5 & 5.8 & 31.7 & 21.3 & 10.1 & 3.4 & 19.8 \\
\hline 1999 & 100.0 & 78.8 & 55.8 & 51.7 & 5.4 & 31.4 & 21.1 & 10.1 & 3.4 & 21.2 \\
\hline 1998 & 100.0 & 77.8 & 53.2 & 48.9 & 5.1 & 32.9 & 22.5 & 10.6 & 3.2 & 22.2 \\
\hline $1997^{5}$ & 100.0 & 78.5 & 53.6 & 49.4 & 5.3 & 32.2 & 22.4 & 10.3 & 3.2 & 21.5 \\
\hline $1996 \ldots \ldots \ldots$ & 100.0 & 78.3 & 51.8 & 47.8 & 5.1 & 35.3 & 25.1 & 9.9 & 4.0 & 21.7 \\
\hline $1995 \ldots$ & 100.0 & 79.0 & 50.5 & 46.3 & 5.4 & 36.8 & 27.1 & 9.8 & 3.5 & 21.0 \\
\hline $1994^{6}$ & 100.0 & 80.3 & 51.1 & 46.5 & 6.4 & 37.9 & 26.9 & 9.4 & 5.0 & 19.7 \\
\hline $1993^{7}$ & 100.0 & 79.5 & 50.2 & 41.4 & (NA) & 38.1 & 28.1 & 9.3 & 4.0 & 20.5 \\
\hline $1992^{8}$ & 100.0 & 79.8 & 49.2 & 41.6 & (NA) & 38.3 & 28.0 & 9.7 & 4.5 & 20.2 \\
\hline 1991. & 100.0 & 79.3 & 49.2 & 42.3 & (NA) & 37.5 & 26.6 & 10.3 & 4.7 & 20.7 \\
\hline $1990 \ldots$ & 100.0 & 80.3 & 51.6 & 43.9 & (NA) & 36.1 & 25.3 & 10.1 & 4.5 & 19.7 \\
\hline $1989 \ldots \ldots \ldots$ & 100.0 & 80.8 & 54.4 & 46.7 & (NA) & 34.4 & 23.4 & 10.0 & 4.4 & 19.2 \\
\hline 1988 & 100.0 & 80.4 & 52.9 & 44.9 & (NA) & 34.8 & 23.6 & 10.2 & 4.6 & 19.6 \\
\hline $1987^{9}$ & 100.0 & 80.1 & 52.2 & 44.4 & (NA) & 35.3 & 24.0 & 9.9 & 5.1 & 19.9 \\
\hline \multicolumn{11}{|l|}{$\begin{array}{l}\text { ASIAN ALONE OR IN } \\
\text { COMBINATION }\end{array}$} \\
\hline \multicolumn{11}{|l|}{ Numbers } \\
\hline 2005 & 13,758 & 11,370 & 9,756 & 8,685 & 1,241 & 2,565 & 1,348 & 1,133 & 461 & 2,388 \\
\hline $2004^{2}$ & 13,307 & 11,148 & 9,468 & 8,294 & 1,329 & 2,602 & 1,393 & 1,110 & 438 & 2,159 \\
\hline 2004 & 13,373 & 11,157 & 9,486 & 8,305 & 1,324 & 2,597 & 1,377 & 1,127 & 433 & 2,217 \\
\hline 2003 & 12,905 & 10,504 & 8,826 & 7,829 & 1,159 & 2,478 & 1,385 & 1,096 & 355 & 2,401 \\
\hline 2002 & 12,504 & 10,256 & 8,639 & 7,576 & 1,194 & 2,341 & 1,322 & 1,008 & 347 & 2,248 \\
\hline \multicolumn{11}{|l|}{ Percents } \\
\hline 2005 & 100.0 & 82.6 & 70.9 & 63.1 & 9.0 & 18.6 & 9.8 & 8.2 & 3.3 & 17.4 \\
\hline $2004^{2}$ & 100.0 & 83.8 & 71.1 & 62.3 & 10.0 & 19.6 & 10.5 & 8.3 & 3.3 & 16.2 \\
\hline 2004 & 100.0 & 83.4 & 70.9 & 62.1 & 9.9 & 19.4 & 10.3 & 8.4 & 3.2 & 16.6 \\
\hline 2003 & 100.0 & 81.4 & 68.4 & 60.7 & 9.0 & 19.2 & 10.7 & 8.5 & 2.8 & 18.6 \\
\hline $2002 \ldots \ldots \ldots \ldots \ldots \ldots \ldots \ldots$ & 100.0 & 82.0 & 69.1 & 60.6 & 9.5 & 18.7 & 10.6 & 8.1 & 2.8 & 18.0 \\
\hline
\end{tabular}

See footnotes at end of table. 
Table C-1.

Health Insurance Coverage by Race and Hispanic Origin: 1987 to 2005-Con.

(Numbers in thousands. People as of March of the following year)

\begin{tabular}{|c|c|c|c|c|c|c|c|c|c|c|}
\hline \multirow{3}{*}{$\begin{array}{l}\text { Race, Hispanic origin, } \\
\text { and year }\end{array}$} & \multirow[b]{3}{*}{$\begin{array}{r}\text { Total } \\
\text { people }\end{array}$} & \multicolumn{8}{|c|}{ Covered by private and/or government health insurance } & \multirow[b]{3}{*}{$\begin{array}{r}\text { No } \\
\text { coverec }\end{array}$} \\
\hline & & & \multicolumn{3}{|c|}{ Private health insurance } & \multicolumn{4}{|c|}{ Government health insurance } & \\
\hline & & Total & Total & $\begin{array}{r}\text { Employ- } \\
\text { ment } \\
\text { based }\end{array}$ & $\begin{array}{r}\text { Direct } \\
\text { purchase }\end{array}$ & Total & Medicaid & Medicare & $\begin{array}{r}\text { Military } \\
\text { health } \\
\text { care }^{1}\end{array}$ & \\
\hline \multicolumn{11}{|l|}{ ASIAN ALONE ${ }^{13}$} \\
\hline \multicolumn{11}{|l|}{ Numbers } \\
\hline 2005 & 12,599 & 10,342 & 8,883 & 7,872 & 1,175 & 2,307 & 1,218 & 1,103 & 353 & 2,257 \\
\hline $2004^{2}$ & 12,241 & 10,225 & 8,678 & 7,593 & 1,237 & 2,400 & 1,282 & 1,081 & 366 & 2,016 \\
\hline 2004 & 12,311 & 10,241 & 8,704 & 7,612 & 1,231 & 2,396 & 1,267 & 1,098 & 360 & 2,070 \\
\hline 2003 & 11,869 & 9,641 & 8,143 & 7,210 & 1,095 & 2,244 & 1,229 & 1,067 & 295 & 2,228 \\
\hline 2002 & 11,558 & 9,426 & 7,939 & 6,932 & 1,137 & 2,132 & 1,202 & 988 & 270 & 2,132 \\
\hline \multicolumn{11}{|l|}{ Percents } \\
\hline 2005 & 100.0 & 82.1 & 70.5 & 62.5 & 9.3 & 18.3 & 9.7 & 8.8 & 2.8 & 17.9 \\
\hline $2004^{2}$ & 100.0 & 83.5 & 70.9 & 62.0 & 10.1 & 19.6 & 10.5 & 8.8 & 3.0 & 16.5 \\
\hline $2004 \ldots$ & 100.0 & 83.2 & 70.7 & 61.8 & 10.0 & 19.5 & 10.3 & 8.9 & 2.9 & 16.8 \\
\hline 2003 & 100.0 & 81.2 & 68.6 & 60.7 & 9.2 & 18.9 & 10.4 & 9.0 & 2.5 & 18.8 \\
\hline 2002 & 100.0 & 81.6 & 68.7 & 60.0 & 9.8 & 18.4 & 10.4 & 8.5 & 2.3 & 18.4 \\
\hline \multicolumn{11}{|l|}{$\begin{array}{l}\text { ASIAN AND PACIFIC } \\
\text { ISLANDER }^{11}\end{array}$} \\
\hline \multicolumn{11}{|l|}{ Numbers } \\
\hline 2001 & 12,500 & 10,222 & 8,643 & 7,684 & 1,088 & 2,312 & 1,257 & 949 & 414 & 2,278 \\
\hline $2000^{3}$ & 12,693 & 10,405 & 8,916 & 8,104 & 994 & 2,249 & 1,288 & 886 & 443 & 2,287 \\
\hline $1999^{4}$ & 11,964 & 9,673 & 8,189 & 7,331 & 964 & 2,204 & 1,179 & 897 & 450 & 2,292 \\
\hline $1999 \ldots$ & 10,925 & 8,653 & 7,285 & 6,588 & 805 & 2,023 & 1,087 & 825 & 412 & 2,272 \\
\hline 1998 & 10,897 & 8,596 & 7,202 & 6,511 & 857 & 2,113 & 1,201 & 819 & 351 & 2,301 \\
\hline $1997^{5}$ & 10,492 & 8,320 & 7,100 & 6,290 & 848 & 1,877 & 1,093 & 700 & 334 & 2,173 \\
\hline $1996 \ldots$ & 10,071 & 7,946 & 6,718 & 5,888 & 962 & 1,768 & 1,071 & 667 & 275 & 2,125 \\
\hline 1995 & 9,653 & 7,671 & 6,347 & 5,576 & 963 & 2,075 & 1,272 & 586 & 424 & 1,982 \\
\hline $1994^{6}$ & 6,656 & 5,312 & 4,267 & 3,774 & 698 & 1,551 & 883 & 501 & 426 & 1,344 \\
\hline $1993^{7}$ & 7,444 & 5,927 & 5,026 & 3,970 & (NA) & 1,408 & 802 & 474 & 345 & 1,517 \\
\hline $1992^{8} \quad \ldots$ & 7,782 & 6,230 & 5,202 & 4,207 & (NA) & 1,460 & 823 & 507 & 314 & 1,552 \\
\hline 1991 & 7,193 & 5,886 & 4,917 & 3,995 & (NA) & 1,451 & 727 & 560 & 347 & 1,307 \\
\hline $1990 \ldots \ldots$ & 7,023 & 5,832 & 4,887 & 3,883 & (NA) & 1,410 & 771 & 463 & 364 & 1,191 \\
\hline $1989 \ldots \ldots$ & 6,679 & 5,532 & 4,615 & 3,661 & (NA) & 1,414 & 792 & 444 & 322 & 1,147 \\
\hline 1988 & 6,447 & 5,329 & 4,392 & 3,599 & (NA) & 1,353 & 763 & 401 & 322 & 1,118 \\
\hline $1987^{9} \ldots \ldots$ & 6,326 & 5,440 & 4,468 & 3,691 & (NA) & 1,394 & 702 & 357 & 475 & 886 \\
\hline \multicolumn{11}{|l|}{ Percents } \\
\hline 2001 & 100.0 & 81.8 & 69.1 & 61.5 & 8.7 & 18.5 & 10.1 & 7.6 & 3.3 & 18.2 \\
\hline $2000^{3}$. & 100.0 & 82.0 & 70.2 & 63.8 & 7.8 & 17.7 & 10.1 & 7.0 & 3.5 & 18.0 \\
\hline $1999^{4}$ & 100.0 & 80.8 & 68.4 & 61.3 & 8.1 & 18.4 & 9.9 & 7.5 & 3.8 & 19.2 \\
\hline 1999 & 100.0 & 79.2 & 66.7 & 60.3 & 7.4 & 18.5 & 9.9 & 7.5 & 3.8 & 20.8 \\
\hline 1998 & 100.0 & 78.9 & 66.1 & 59.8 & 7.9 & 19.4 & 11.0 & 7.5 & 3.2 & 21.1 \\
\hline $1997^{5}$ & 100.0 & 79.3 & 67.7 & 60.0 & 8.1 & 17.9 & 10.4 & 6.7 & 3.2 & 20.7 \\
\hline $1996 \ldots \ldots$ & 100.0 & 78.9 & 66.7 & 58.5 & 9.5 & 17.6 & 10.6 & 6.6 & 2.7 & 21.1 \\
\hline 1995 & 100.0 & 79.5 & 65.8 & 57.8 & 10.0 & 21.5 & 13.2 & 6.1 & 4.4 & 20.5 \\
\hline $1994^{6}$ & 100.0 & 79.8 & 64.1 & 56.7 & 10.5 & 23.3 & 13.3 & 7.5 & 6.4 & 20.2 \\
\hline $1993^{7}$ & 100.0 & 79.6 & 67.5 & 53.3 & (NA) & 18.9 & 10.8 & 6.4 & 4.6 & 20.4 \\
\hline $1992^{8}$ & 100.0 & 80.1 & 66.8 & 54.1 & (NA) & 18.8 & 10.6 & 6.5 & 4.0 & 19.9 \\
\hline $1991 \ldots$ & 100.0 & 81.8 & 68.4 & 55.5 & (NA) & 20.2 & 10.1 & 7.8 & 4.8 & 18.2 \\
\hline $1990 \ldots$ & 100.0 & 83.0 & 69.6 & 55.3 & (NA) & 20.1 & 11.0 & 6.6 & 5.2 & 17.0 \\
\hline $1989 \ldots \ldots$ & 100.0 & 82.8 & 69.1 & 54.8 & (NA) & 21.2 & 11.9 & 6.6 & 4.8 & 17.2 \\
\hline 1988 & 100.0 & 82.7 & 68.1 & 55.8 & (NA) & 21.0 & 11.8 & 6.2 & 5.0 & 17.3 \\
\hline $1987^{9}$ & 100.0 & 86.0 & 70.6 & 58.3 & (NA) & 22.0 & 11.1 & 5.6 & 7.5 & 14.0 \\
\hline
\end{tabular}

See footnotes at end of table. 
Table C-1.

Health Insurance Coverage by Race and Hispanic Origin: 1987 to 2005-Con.

(Numbers in thousands. People as of March of the following year)

\begin{tabular}{|c|c|c|c|c|c|c|c|c|c|c|}
\hline \multirow{3}{*}{$\begin{array}{c}\text { Race, Hispanic origin, } \\
\text { and year }\end{array}$} & \multirow[b]{3}{*}{$\begin{array}{r}\text { Total } \\
\text { people }\end{array}$} & \multicolumn{8}{|c|}{ Covered by private and/or government health insurance } & \multirow[b]{3}{*}{$\begin{array}{r}\text { Not } \\
\text { covered }\end{array}$} \\
\hline & & & \multicolumn{3}{|c|}{ Private health insurance } & \multicolumn{4}{|c|}{ Government health insurance } & \\
\hline & & Total & Total & $\begin{array}{r}\text { Employ- } \\
\text { ment } \\
\text { based }\end{array}$ & $\begin{array}{r}\text { Direct } \\
\text { purchase }\end{array}$ & Total & Medicaid & Medicare & $\begin{array}{r}\text { Military } \\
\text { health } \\
\text { care }^{1}\end{array}$ & \\
\hline \multicolumn{11}{|l|}{ HISPANIC (any race) } \\
\hline \multicolumn{11}{|l|}{ Numbers } \\
\hline 2005 & 43,168 & 29,046 & 19,066 & 17,426 & 1,840 & 11,959 & 9,357 & 2,771 & 870 & 14,122 \\
\hline $2004^{2}$ & 41,840 & 28,336 & 18,864 & 17,289 & 1,766 & 11,528 & 9,204 & 2,614 & 697 & 13,504 \\
\hline 2004. & 41,839 & 28,160 & 18,714 & 17,208 & 1,698 & 11,462 & 9,123 & 2,618 & 694 & 13,678 \\
\hline 2003 & 40,425 & 27,188 & 18,183 & 16,788 & 1,551 & 10,716 & 8,505 & 2,462 & 639 & 13,237 \\
\hline 2002 & 39,384 & 26,627 & 18,108 & 16,714 & 1,469 & 10,280 & 7,946 & 2,535 & 724 & 12,756 \\
\hline 2001 & 37,438 & 25,021 & 17,322 & 15,965 & 1,390 & 9,227 & 7,074 & 2,295 & 704 & 12,417 \\
\hline $2000^{3}$ & 36,093 & 24,210 & 17,114 & 15,893 & 1,337 & 8,566 & 6,552 & 2,141 & 682 & 11,883 \\
\hline $1999^{4}$ & 34,773 & 23,311 & 16,634 & 15,275 & 1,398 & 8,168 & 6,253 & 1,979 & 626 & 11,462 \\
\hline 1999. & 32,804 & 21,853 & 15,424 & 14,214 & 1,264 & 7,875 & 5,946 & 2,047 & 589 & 10,951 \\
\hline 1998 & 31,689 & 20,493 & 14,377 & 13,310 & 1,133 & 7,401 & 5,585 & 2,026 & 503 & 11,196 \\
\hline $1997^{5}$ & 30,773 & 20,239 & 13,751 & 12,790 & 1,028 & 7,718 & 5,970 & 1,974 & 526 & 10,534 \\
\hline 1996. & 29,703 & 19,730 & 13,151 & 12,140 & 1,105 & 7,784 & 6,255 & 1,806 & 474 & 9,974 \\
\hline 1995 & 28,438 & 18,964 & 12,187 & 11,309 & 1,011 & 8,027 & 6,478 & 1,732 & 516 & 9,474 \\
\hline $1994^{6}$ & 27,521 & 18,244 & 11,743 & 10,729 & 1,208 & 7,829 & 6,226 & 1,677 & 630 & 9,277 \\
\hline $1993^{7}$ & 26,646 & 18,235 & 12,021 & 9,981 & (NA) & 7,873 & 6,328 & 1,613 & 530 & 8,411 \\
\hline $1992^{8}$ & 25,682 & 17,242 & 11,330 & 9,786 & (NA) & 7,099 & 5,703 & 1,578 & 523 & 8,441 \\
\hline 1991. & 22,096 & 15,128 & 10,336 & 8,972 & (NA) & 5,845 & 4,597 & 1,309 & 522 & 6,968 \\
\hline 1990 & 21,437 & 14,479 & 10,281 & 8,948 & (NA) & 5,169 & 3,912 & 1,269 & 519 & 6,958 \\
\hline $1989 \ldots$ & 20,779 & 13,846 & 10,348 & 8,914 & (NA) & 4,526 & 3,221 & 1,180 & 595 & 6,932 \\
\hline 1988 & 20,076 & 13,684 & 10,188 & 8,831 & (NA) & 4,414 & 3,125 & 1,114 & 594 & 6,391 \\
\hline $1987^{9}$ & 19,428 & 13,456 & 9,845 & 8,490 & (NA) & 4,482 & 3,214 & 1,029 & 631 & 5,972 \\
\hline \multicolumn{11}{|l|}{ Percents } \\
\hline 2005 & 100.0 & 67.3 & 44.2 & 40.4 & 4.3 & 27.7 & 21.7 & 6.4 & 2.0 & 32.7 \\
\hline $2004^{2}$ & 100.0 & 67.7 & 45.1 & 41.3 & 4.2 & 27.6 & 22.0 & 6.2 & 1.7 & 32.3 \\
\hline 2004 & 100.0 & 67.3 & 44.7 & 41.1 & 4.1 & 27.4 & 21.8 & 6.3 & 1.7 & 32.7 \\
\hline 2003 & 100.0 & 67.3 & 45.0 & 41.5 & 3.8 & 26.5 & 21.0 & 6.1 & 1.6 & 32.7 \\
\hline 2002 & 100.0 & 67.6 & 46.0 & 42.4 & 3.7 & 26.1 & 20.2 & 6.4 & 1.8 & 32.4 \\
\hline 2001. & 100.0 & 66.8 & 46.3 & 42.6 & 3.7 & 24.6 & 18.9 & 6.1 & 1.9 & 33.2 \\
\hline $2000^{3}$ & 100.0 & 67.1 & 47.4 & 44.0 & 3.7 & 23.7 & 18.2 & 5.9 & 1.9 & 32.9 \\
\hline $1999^{4}$ & 100.0 & 67.0 & 47.8 & 43.9 & 4.0 & 23.5 & 18.0 & 5.7 & 1.8 & 33.0 \\
\hline $1999 \ldots$ & 100.0 & 66.6 & 47.0 & 43.3 & 3.9 & 24.0 & 18.1 & 6.2 & 1.8 & 33.4 \\
\hline 1998 & 100.0 & 64.7 & 45.4 & 42.0 & 3.6 & 23.4 & 17.6 & 6.4 & 1.6 & 35.3 \\
\hline $1997^{5}$ & 100.0 & 65.8 & 44.7 & 41.6 & 3.3 & 25.1 & 19.4 & 6.4 & 1.7 & 34.2 \\
\hline 1996 & 100.0 & 66.4 & 44.3 & 40.9 & 3.7 & 26.2 & 21.1 & 6.1 & 1.6 & 33.6 \\
\hline 1995. & 100.0 & 66.7 & 42.9 & 39.8 & 3.6 & 28.2 & 22.8 & 6.1 & 1.8 & 33.3 \\
\hline $1994^{6}$ & 100.0 & 66.3 & 42.7 & 39.0 & 4.4 & 28.4 & 22.6 & 6.1 & 2.3 & 33.7 \\
\hline $1993^{7}$ & 100.0 & 68.4 & 45.1 & 37.5 & (NA) & 29.5 & 23.7 & 6.1 & 2.0 & 31.6 \\
\hline $1992^{8}$ & 100.0 & 67.1 & 44.1 & 38.1 & (NA) & 27.6 & 22.2 & 6.1 & 2.0 & 32.9 \\
\hline 1991 & 100.0 & 68.5 & 46.8 & 40.6 & (NA) & 26.5 & 20.8 & 5.9 & 2.4 & 31.5 \\
\hline 1990 & 100.0 & 67.5 & 48.0 & 41.7 & (NA) & 24.1 & 18.2 & 5.9 & 2.4 & 32.5 \\
\hline 1989 & 100.0 & 66.6 & 49.8 & 42.9 & (NA) & 21.8 & 15.5 & 5.7 & 2.9 & 33.4 \\
\hline 1988 & 100.0 & 68.2 & 50.7 & 44.0 & (NA) & 22.0 & 15.6 & 5.5 & 3.0 & 31.8 \\
\hline $1987^{9}$ & 100.0 & 69.3 & 50.7 & 43.7 & (NA) & 23.1 & 16.5 & 5.3 & 3.2 & 30.7 \\
\hline
\end{tabular}

(NA) Not available. Respondents were not asked detailed health insurance questions about direct-purchase coverage before the 1995 CPS ASEC.

${ }^{1}$ Military health care includes CHAMPUS (Comprehensive Health and Medical Plan for Uniformed Services)/Tricare and CHAMPVA (Civilian Health and Medical Program of the Department of Veterans Affairs), as well as care provided by the Health and Medical Program of the Department of Veterans Affairs and care provided by the Department of Veterans Affairs and the military.

2 The 2004 data have been revised to reflect a correction to the weights in the 2005 ASEC. The estimates also reflect improvements to the algorithm that assigns coverage to dependents.

${ }^{3}$ Implementation of a 28,000 household sample expansion.

${ }^{4}$ Estimates reflect the results of follow-up verification questions and implementation of Census 2000-based population controls.

${ }^{5}$ Beginning with the 1998 CPS ASEC, people with no coverage other than access to Indian Health Service are no longer considered covered by health insurance; instead, they are considered to be uninsured. The effect of this change on the overall estimates of health insurance coverage is negligible; however, the decrease in the number of people covered by Medicaid may be partially due to this change.

${ }^{6}$ Health insurance questions were redesigned. Increases in estimates of employment-based and military health care coverage may be partially due to questionnaire changes. Overall coverage estimates were not affected.

7 Data collection method changed from paper and pencil to computer-assisted interviewing.

8 Implementation of 1990 census population controls. 
9 Implementation of a new CPS ASEC processing system.

10 The 2003 CPS asked respondents to choose one or more races. White alone refers to people who reported White and did not report any other race category. The use of this single-race population does not imply that it is the preferred method of presenting or analyzing data. The Census Bureau uses a variety of approaches.

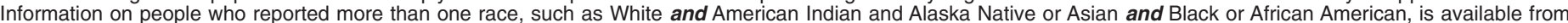
Census 2000 through American FactFinder. About 2.6 percent of people reported more than one race in Census 2000

${ }^{11}$ The 2001 CPS and earlier years asked respondents to report only one race. The reference groups for these years are White; White, not Hispanic; Black; and Asian and Pacific Islander.

12 Black alone refers to people who reported Black or African American and did not report any other race.

${ }_{13}$ Asian alone refers to people who reported Asian and did not report any other race.

Source: U.S. Census Bureau, Current Population Survey, 1988 to 2006 Annual Social and Economic Supplements. 


\section{Table C-2.}

\section{Health Insurance Coverage by Age: 1987 to 2005}

(Numbers in thousands. People as of March of the following year)

\begin{tabular}{|c|c|c|c|c|c|c|c|c|c|c|}
\hline \multirow{3}{*}{ Age and year } & \multirow[b]{3}{*}{$\begin{array}{r}\text { Total } \\
\text { people }\end{array}$} & \multicolumn{8}{|c|}{ Covered by private and/or government health insurance } & \multirow[b]{3}{*}{$\begin{array}{r}\text { Not } \\
\text { covered }\end{array}$} \\
\hline & & & \multicolumn{3}{|c|}{ Private health insurance } & \multicolumn{4}{|c|}{ Government health insurance } & \\
\hline & & Total & Total & $\begin{array}{r}\text { Employ- } \\
\text { ment } \\
\text { based }\end{array}$ & $\begin{array}{r}\text { Direct } \\
\text { purchase }\end{array}$ & Total & Medicaid & Medicare & $\begin{array}{r}\text { Military } \\
\text { health } \\
\text { care }^{1}\end{array}$ & \\
\hline \multicolumn{11}{|l|}{ ALL AGES } \\
\hline \multicolumn{11}{|l|}{ Numbers } \\
\hline 2005 & 293,834 & 247,257 & 198,901 & 174,819 & 26,781 & 80,249 & 38,134 & 40,185 & 11,172 & 46,577 \\
\hline $2004^{2}$ & 291,166 & 245,860 & 198,658 & 174,186 & 27,193 & 79,392 & 37,963 & 39,708 & 10,660 & 45,306 \\
\hline 2004 & 291,155 & 245,335 & 198,262 & 174,174 & 26,961 & 79,086 & 37,514 & 39,745 & 10,680 & 45,820 \\
\hline 2003 & 288,280 & 243,320 & 197,869 & 174,020 & 26,486 & 76,755 & 35,647 & 39,456 & 9,979 & 44,961 \\
\hline 2002 & 285,933 & 242,360 & 198,973 & 175,296 & 26,639 & 73,624 & 33,246 & 38,448 & 10,063 & 43,574 \\
\hline 2001. & 282,082 & 240,875 & 199,860 & 176,551 & 26,057 & 71,295 & 31,601 & 38,043 & 9,552 & 41,207 \\
\hline $2000^{3}$ & 279,517 & 239,714 & 201,060 & 177,848 & 26,524 & 69,037 & 29,533 & 37,740 & 9,099 & 39,804 \\
\hline $1999^{4}$ & 276,804 & 236,576 & 198,841 & 175,101 & 27,415 & 67,683 & 28,506 & 36,923 & 8,648 & 40,228 \\
\hline 1999. & 274,087 & 231,533 & 194,599 & 172,023 & 26,179 & 66,176 & 27,890 & 36,066 & 8,530 & 42,554 \\
\hline 1998 & 271,743 & 227,462 & 190,861 & 168,576 & 25,948 & 66,087 & 27,854 & 35,887 & 8,747 & 44,281 \\
\hline $1997^{5}$ & 269,094 & 225,646 & 188,532 & 165,091 & 27,158 & 66,685 & 28,956 & 35,590 & 8,527 & 43,448 \\
\hline 1996. & 266,792 & 225,077 & 187,395 & 163,221 & 28,335 & 69,000 & 31,451 & 35,227 & 8,712 & 41,716 \\
\hline 1995. & 264,314 & 223,733 & 185,881 & 161,453 & 30,188 & 69,776 & 31,877 & 34,655 & 9,375 & 40,582 \\
\hline $1994^{6}$ & 262,105 & 222,387 & 184,318 & 159,634 & 31,349 & 70,163 & 31,645 & 33,901 & 11,165 & 39,718 \\
\hline $1993^{7}$ & 259,753 & 220,040 & 182,351 & 148,318 & (NA) & 68,554 & 31,749 & 33,097 & 9,560 & 39,713 \\
\hline $1992^{8}$ & 256,830 & 218,189 & 181,466 & 148,796 & (NA) & 66,244 & 29,416 & 33,230 & 9,510 & 38,641 \\
\hline 1991. & 251,447 & 216,003 & 181,375 & 150,077 & (NA) & 63,882 & 26,880 & 32,907 & 9,820 & 35,445 \\
\hline 1990 & 248,886 & 214,167 & 182,135 & 150,215 & (NA) & 60,965 & 24,261 & 32,260 & 9,922 & 34,719 \\
\hline 1989 & 246,191 & 212,807 & 183,610 & 151,644 & (NA) & 57,382 & 21,185 & 31,495 & 9,870 & 33,385 \\
\hline 1988 & 243,685 & 211,005 & 182,019 & 150,940 & (NA) & 56,850 & 20,728 & 30,925 & 10,105 & 32,680 \\
\hline $1987^{9}$ & 241,187 & 210,161 & 182,160 & 149,739 & (NA) & 56,282 & 20,211 & 30,458 & 10,542 & 31,026 \\
\hline \multicolumn{11}{|l|}{ Percents } \\
\hline 2005 & 100.0 & 84.1 & 67.7 & 59.5 & 9.1 & 27.3 & 13.0 & 13.7 & 3.8 & 15.9 \\
\hline $2004^{2}$ & 100.0 & 84.4 & 68.2 & 59.8 & 9.3 & 27.3 & 13.0 & 13.6 & 3.7 & 15.6 \\
\hline 2004. & 100.0 & 84.3 & 68.1 & 59.8 & 9.3 & 27.2 & 12.9 & 13.7 & 3.7 & 15.7 \\
\hline 2003 & 100.0 & 84.4 & 68.6 & 60.4 & 9.2 & 26.6 & 12.4 & 13.7 & 3.5 & 15.6 \\
\hline 2002 & 100.0 & 84.8 & 69.6 & 61.3 & 9.3 & 25.7 & 11.6 & 13.4 & 3.5 & 15.2 \\
\hline 2001 & 100.0 & 85.4 & 70.9 & 62.6 & 9.2 & 25.3 & 11.2 & 13.5 & 3.4 & 14.6 \\
\hline $2000^{3}$ & 100.0 & 85.8 & 71.9 & 63.6 & 9.5 & 24.7 & 10.6 & 13.5 & 3.3 & 14.2 \\
\hline $1999^{4}$ & 100.0 & 85.5 & 71.8 & 63.3 & 9.9 & 24.5 & 10.3 & 13.3 & 3.1 & 14.5 \\
\hline 1999 & 100.0 & 84.5 & 71.0 & 62.8 & 9.6 & 24.1 & 10.2 & 13.2 & 3.1 & 15.5 \\
\hline 1998 & 100.0 & 83.7 & 70.2 & 62.0 & 9.5 & 24.3 & 10.3 & 13.2 & 3.2 & 16.3 \\
\hline $1997^{5}$ & 100.0 & 83.9 & 70.1 & 61.4 & 10.1 & 24.8 & 10.8 & 13.2 & 3.2 & 16.1 \\
\hline 1996. & 100.0 & 84.4 & 70.2 & 61.2 & 10.6 & 25.9 & 11.8 & 13.2 & 3.3 & 15.6 \\
\hline 1995 & 100.0 & 84.6 & 70.3 & 61.1 & 11.4 & 26.4 & 12.1 & 13.1 & 3.5 & 15.4 \\
\hline $1994^{6}$ & 100.0 & 84.8 & 70.3 & 60.9 & 12.0 & 26.8 & 12.1 & 12.9 & 4.3 & 15.2 \\
\hline $1993^{7}$ & 100.0 & 84.7 & 70.2 & 57.1 & (NA) & 26.4 & 12.2 & 12.7 & 3.7 & 15.3 \\
\hline $1992^{8}$ & 100.0 & 85.0 & 70.7 & 57.9 & (NA) & 25.8 & 11.5 & 12.9 & 3.7 & 15.0 \\
\hline 1991. & 100.0 & 85.9 & 72.1 & 59.7 & (NA) & 25.4 & 10.7 & 13.1 & 3.9 & 14.1 \\
\hline 1990 & 100.0 & 86.1 & 73.2 & 60.4 & (NA) & 24.5 & 9.7 & 13.0 & 4.0 & 13.9 \\
\hline 1989 & 100.0 & 86.4 & 74.6 & 61.6 & (NA) & 23.3 & 8.6 & 12.8 & 4.0 & 13.6 \\
\hline 1988 & 100.0 & 86.6 & 74.7 & 61.9 & (NA) & 23.3 & 8.5 & 12.7 & 4.1 & 13.4 \\
\hline $1987^{\circ}$ & 100.0 & 87.1 & 75.5 & 62.1 & (NA) & 23.3 & 8.4 & 12.6 & 4.4 & 12.9 \\
\hline
\end{tabular}

See footnotes at end of table. 
Table C-2.

Health Insurance Coverage by Age: 1987 to 2005-Con.

(Numbers in thousands. People as of March of the following year)

\begin{tabular}{|c|c|c|c|c|c|c|c|c|c|c|}
\hline \multirow{3}{*}{ Age and year } & \multirow[b]{3}{*}{$\begin{array}{l}\text { Total } \\
\text { people }\end{array}$} & \multicolumn{8}{|c|}{ Covered by private and/or government health insurance } & \multirow[b]{3}{*}{$\begin{array}{r}\text { No } \\
\text { covereo }\end{array}$} \\
\hline & & & \multicolumn{3}{|c|}{ Private health insurance } & \multicolumn{4}{|c|}{ Government health insurance } & \\
\hline & & Total & Total & $\begin{array}{r}\text { Employ- } \\
\text { ment } \\
\text { based }\end{array}$ & $\begin{array}{r}\text { Direct } \\
\text { purchase }\end{array}$ & Total & Medicaid & Medicare & $\begin{array}{r}\text { Military } \\
\text { health } \\
\text { care }^{1}\end{array}$ & \\
\hline \multicolumn{11}{|l|}{ UNDER 18 YEARS } \\
\hline \multicolumn{11}{|l|}{ Numbers } \\
\hline 2005 & 73,985 & 65,675 & 48,395 & 44,741 & 4,033 & 21,944 & 19,737 & 543 & 2,262 & 8,310 \\
\hline $2004^{2}$ & 73,791 & 65,842 & 48,772 & 45,041 & 4,247 & 21,994 & 19,921 & 503 & 2,041 & 7,949 \\
\hline$\ldots \ldots \ldots \ldots$ & 73,821 & 65,553 & 48,462 & 44,892 & 4,166 & 21,922 & 19,847 & 500 & 2,045 & 8,269 \\
\hline 2003 & 73,580 & 65,207 & 48,475 & 45,004 & 3,893 & 21,389 & 19,392 & 483 & 2,021 & 8,373 \\
\hline 2002 & 73,312 & 64,781 & 49,473 & 46,182 & 3,864 & 19,662 & 17,526 & 524 & 2,148 & 8,531 \\
\hline 2001 & 72,628 & 64,118 & 49,647 & 46,439 & 3,624 & 18,822 & 16,502 & 423 & 2,381 & 8,509 \\
\hline $2000^{3}$ & 72,314 & 63,697 & 50,499 & 47,431 & 3,586 & 17,658 & 15,090 & 518 & 2,563 & 8,617 \\
\hline $1999^{4}$ & 72,281 & 62,996 & 50,300 & 46,834 & 4,052 & 16,793 & 14,697 & 364 & 2,076 & 9,285 \\
\hline 1999 & 72,325 & 62,302 & 49,822 & 46,594 & 3,868 & 16,579 & 14,479 & 355 & 2,080 & 10,023 \\
\hline 1998 & 72,022 & 60,949 & 48,627 & 45,593 & 3,666 & 16,400 & 14,274 & 325 & 2,240 & 11,073 \\
\hline $1997^{5}$ & 71,682 & 60,939 & 47,968 & 44,869 & 3,672 & 16,800 & 14,683 & 395 & 2,163 & 10,743 \\
\hline 1996. & 71,224 & 60,670 & 47,219 & 44,054 & 3,865 & 17,749 & 15,502 & 484 & 2,291 & 10,554 \\
\hline 1995 & 71,148 & 61,353 & 47,021 & 43,822 & 4,217 & 18,755 & 16,524 & 348 & 2,336 & 9,795 \\
\hline $1994^{6}$ & 70,509 & 60,505 & 46,266 & 42,966 & 4,634 & 18,559 & 16,132 & 228 & 2,708 & 10,003 \\
\hline $1993^{7}$ & 69,766 & 60,192 & 47,017 & 39,745 & (NA) & 18,696 & 16,693 & 48 & 2,307 & 9,574 \\
\hline $1992^{8}$ & 68,720 & 60,005 & 47,183 & 40,382 & (NA) & 17,294 & 15,109 & 97 & 2,378 & 8,716 \\
\hline$\ldots \ldots \ldots \ldots$ & 66,173 & 57,794 & 46,114 & 39,683 & (NA) & 15,792 & 13,514 & 52 & 2,425 & 8,379 \\
\hline 1990 & 65,290 & 56,786 & 46,436 & 39,981 & (NA) & 14,300 & 12,094 & 88 & 2,408 & 8,504 \\
\hline 1989 & 64,343 & 55,795 & 47,376 & 40,610 & (NA) & 12,345 & 10,100 & 43 & 2,425 & 8,548 \\
\hline 1988 & 63,902 & 55,552 & 46,944 & 40,750 & (NA) & 12,270 & 9,961 & 62 & 2,469 & 8,350 \\
\hline $1987^{9}$ & 63,499 & 55,306 & 46,763 & 40,577 & (NA) & 12,071 & 9,681 & 53 & 2,567 & 8,193 \\
\hline \multicolumn{11}{|l|}{ Percents } \\
\hline 2005 & 100.0 & 88.8 & 65.4 & 60.5 & 5.5 & 29.7 & 26.7 & 0.7 & 3.1 & 11.2 \\
\hline $2004^{2}$ & 100.0 & 89.2 & 66.1 & 61.0 & 5.8 & 29.8 & 27.0 & 0.7 & 2.8 & 10.8 \\
\hline 2004 & 100.0 & 88.8 & 65.6 & 60.8 & 5.6 & 29.7 & 26.9 & 0.7 & 2.8 & 11.2 \\
\hline$\ldots \ldots \ldots \ldots$ & 100.0 & 88.6 & 65.9 & 61.2 & 5.3 & 29.1 & 26.4 & 0.7 & 2.7 & 11.4 \\
\hline$\ldots \ldots \ldots \ldots$ & 100.0 & 88.4 & 67.5 & 63.0 & 5.3 & 26.8 & 23.9 & 0.7 & 2.9 & 11.6 \\
\hline 2001 & 100.0 & 88.3 & 68.4 & 63.9 & 5.0 & 25.9 & 22.7 & 0.6 & 3.3 & 11.7 \\
\hline $2000^{3}$ & 100.0 & 88.1 & 69.8 & 65.6 & 5.0 & 24.4 & 20.9 & 0.7 & 3.5 & 11.9 \\
\hline $1999^{4}$ & 100.0 & 87.2 & 69.6 & 64.8 & 5.6 & 23.2 & 20.3 & 0.5 & 2.9 & 12.8 \\
\hline 1999 & 100.0 & 86.1 & 68.9 & 64.4 & 5.3 & 22.9 & 20.0 & 0.5 & 2.9 & 13.9 \\
\hline 1998 & 100.0 & 84.6 & 67.5 & 63.3 & 5.1 & 22.8 & 19.8 & 0.5 & 3.1 & 15.4 \\
\hline $1997^{5}$ & 100.0 & 85.0 & 66.9 & 62.6 & 5.1 & 23.4 & 20.5 & 0.6 & 3.0 & 15.0 \\
\hline 1996 & 100.0 & 85.2 & 66.3 & 61.9 & 5.4 & 24.9 & 21.8 & 0.7 & 3.2 & 14.8 \\
\hline 1995 & 100.0 & 86.2 & 66.1 & 61.6 & 5.9 & 26.4 & 23.2 & 0.5 & 3.3 & 13.8 \\
\hline $1994^{6}$ & 100.0 & 85.8 & 65.6 & 60.9 & 6.6 & 26.3 & 22.9 & 0.3 & 3.8 & 14.2 \\
\hline $1993^{7}$ & 100.0 & 86.3 & 67.4 & 57.0 & (NA) & 26.8 & 23.9 & 0.1 & 3.3 & 13.7 \\
\hline $1992^{8}$ & 100.0 & 87.3 & 68.7 & 58.8 & (NA) & 25.2 & 22.0 & 0.1 & 3.5 & 12.7 \\
\hline 1991 & 100.0 & 87.3 & 69.7 & 60.0 & (NA) & 23.9 & 20.4 & 0.1 & 3.7 & 12.7 \\
\hline 1990 & 100.0 & 87.0 & 71.1 & 61.2 & (NA) & 21.9 & 18.5 & 0.1 & 3.7 & 13.0 \\
\hline 1989 & 100.0 & 86.7 & 73.6 & 63.1 & (NA) & 19.2 & 15.7 & 0.1 & 3.8 & 13.3 \\
\hline$\ldots \ldots \ldots \ldots$ & 100.0 & 86.9 & 73.5 & 63.8 & (NA) & 19.2 & 15.6 & 0.1 & 3.9 & 13.1 \\
\hline $1987^{9}$ & 100.0 & 87.1 & 73.6 & 63.9 & (NA) & 19.0 & 15.2 & 0.1 & 4.0 & 12.9 \\
\hline
\end{tabular}

See footnotes at end of table. 
Table C-2.

Health Insurance Coverage by Age: 1987 to 2005-Con.

(Numbers in thousands. People as of March of the following year)

\begin{tabular}{|c|c|c|c|c|c|c|c|c|c|c|}
\hline \multirow{3}{*}{ Age and year } & \multirow[b]{3}{*}{$\begin{array}{r}\text { Total } \\
\text { people }\end{array}$} & \multicolumn{8}{|c|}{ Covered by private and/or government health insurance } & \multirow[b]{3}{*}{$\begin{array}{r}\text { Not } \\
\text { covered }\end{array}$} \\
\hline & & & \multicolumn{3}{|c|}{ Private health insurance } & \multicolumn{4}{|c|}{ Government health insurance } & \\
\hline & & Total & Total & $\begin{array}{r}\text { Employ- } \\
\text { ment } \\
\text { based }\end{array}$ & $\begin{array}{r}\text { Direct } \\
\text { purchase }\end{array}$ & Total & Medicaid & Medicare & $\begin{array}{r}\text { Military } \\
\text { health } \\
\text { care }^{1}\end{array}$ & \\
\hline \multicolumn{11}{|l|}{18 TO 24 YEARS } \\
\hline \multicolumn{11}{|l|}{ Numbers } \\
\hline 2005 & 27,965 & 19,399 & 16,349 & 13,180 & 1,553 & 4,202 & 3,292 & 186 & 872 & 8,566 \\
\hline $2004^{2} \ldots \ldots \ldots \ldots \ldots \ldots \ldots$ & 28,008 & 19,418 & 16,388 & 13,007 & 1,565 & 4,107 & 3,293 & 208 & 799 & 8,590 \\
\hline $2004 \ldots \ldots \ldots \ldots \ldots \ldots \ldots \ldots \ldots \ldots$ & 27,972 & 19,200 & 16,229 & 12,966 & 1,495 & 4,022 & 3,196 & 212 & 804 & 8,772 \\
\hline $2003 \ldots \ldots \ldots \ldots \ldots \ldots \ldots \ldots$ & 27,824 & 19,410 & 16,526 & 13,434 & 1,596 & 3,929 & 3,016 & 176 & 902 & 8,414 \\
\hline $2002 \ldots \ldots \ldots \ldots \ldots \ldots \ldots \ldots$ & 27,438 & 19,310 & 16,562 & 13,429 & 1,566 & 3,738 & 2,909 & 183 & 779 & 8,128 \\
\hline$\ldots \ldots \ldots \ldots \ldots \ldots \ldots$ & 27,312 & 19,640 & 17,012 & 13,766 & 1,634 & 3,642 & 2,831 & 180 & 742 & 7,673 \\
\hline $2000^{3} \ldots \ldots \ldots$ & 26,815 & 19,409 & 17,086 & 14,151 & 1,533 & 3,361 & 2,508 & 207 & 805 & 7,406 \\
\hline $1999^{4} \ldots \ldots \ldots \ldots \ldots \ldots \ldots \ldots$ & 26,326 & 18,990 & 16,542 & 13,558 & 1,564 & 3,485 & 2,684 & 152 & 787 & 7,336 \\
\hline $1999 \ldots \ldots \ldots \ldots \ldots \ldots \ldots \ldots$ & 26,532 & 18,844 & 16,438 & 13,535 & 1,469 & 3,450 & 2,643 & 152 & 798 & 7,688 \\
\hline $1998 \ldots \ldots \ldots \ldots \ldots \ldots \ldots \ldots \ldots$ & 25,967 & 18,191 & 15,872 & 13,108 & 1,514 & 3,347 & 2,538 & 149 & 795 & 7,776 \\
\hline $1997^{5} \ldots \ldots \ldots \ldots \ldots \ldots \ldots \ldots \ldots \ldots$ & 25,201 & 17,619 & 15,256 & 12,638 & 1,558 & 3,283 & 2,555 & 155 & 692 & 7,582 \\
\hline $1996 \ldots \ldots \ldots \ldots \ldots \ldots \ldots \ldots \ldots \ldots \ldots$ & 24,987 & 17,770 & 15,066 & 12,423 & 1,528 & 3,750 & 2,909 & 156 & 829 & 7,217 \\
\hline $1995 \ldots \ldots \ldots \ldots \ldots \ldots \ldots \ldots$ & 24,843 & 17,847 & 14,961 & 12,492 & 1,688 & 4,018 & 3,003 & 129 & 1,034 & 6,997 \\
\hline $1994^{6} \ldots \ldots$ & 25,158 & 18,446 & 15,528 & 12,895 & 1,854 & 4,246 & 3,179 & 89 & 1,179 & 6,712 \\
\hline $1993^{7} \ldots$ & 25,475 & 18,645 & 15,668 & 11,133 & $(\mathrm{NA})$ & 4,087 & 2,976 & 148 & 1,115 & 6,830 \\
\hline $1992^{8} \ldots$ & 25,717 & 18,146 & 15,155 & 10,981 & (NA) & 3,826 & 2,875 & 178 & 964 & 7,570 \\
\hline $1991 \ldots \ldots \ldots \ldots \ldots \ldots \ldots \ldots$ & 24,436 & 17,851 & 15,168 & 11,474 & (NA) & 3,405 & 2,477 & 163 & 940 & 6,585 \\
\hline $1990 \ldots \ldots \ldots \ldots \ldots \ldots \ldots \ldots$ & 24,901 & 18,408 & 15,913 & 11,999 & (NA) & 3,270 & 2,204 & 161 & 1,094 & 6,493 \\
\hline $1989 \ldots \ldots \ldots \ldots \ldots \ldots \ldots$ & 25,311 & 18,954 & 16,638 & 12,929 & (NA) & 3,114 & 2,057 & 167 & 1,031 & 6,357 \\
\hline $1988 \ldots \ldots \ldots \ldots \ldots \ldots \ldots \ldots$ & 25,628 & 19,354 & 16,965 & 13,098 & (NA) & 3,082 & 2,033 & 170 & 1,007 & 6,274 \\
\hline $1987^{9} \ldots \ldots \ldots \ldots \ldots \ldots \ldots$ & 26,053 & 19,945 & 17,434 & 13,429 & (NA) & 3,280 & 1,968 & 196 & 1,273 & 6,108 \\
\hline \multicolumn{11}{|l|}{ Percents } \\
\hline 2005 & 100.0 & 69.4 & 58.5 & 47.1 & 5.6 & 15.0 & 11.8 & 0.7 & 3.1 & 30.6 \\
\hline $2004^{2} \ldots \ldots \ldots \ldots \ldots \ldots \ldots \ldots \ldots$ & 100.0 & 69.3 & 58.5 & 46.4 & 5.6 & 14.7 & 11.8 & 0.7 & 2.9 & 30.7 \\
\hline $2004 \ldots \ldots \ldots \ldots \ldots \ldots \ldots \ldots \ldots \ldots \ldots \ldots$ & 100.0 & 68.6 & 58.0 & 46.4 & 5.3 & 14.4 & 11.4 & 0.8 & 2.9 & 31.4 \\
\hline $2003 \ldots \ldots \ldots \ldots \ldots \ldots \ldots \ldots \ldots \ldots \ldots \ldots$ & 100.0 & 69.8 & 59.4 & 48.3 & 5.7 & 14.1 & 10.8 & 0.6 & 3.2 & 30.2 \\
\hline $2002 \ldots \ldots \ldots \ldots$ & 100.0 & 70.4 & 60.4 & 48.9 & 5.7 & 13.6 & 10.6 & 0.7 & 2.8 & 29.6 \\
\hline 2001. & 100.0 & 71.9 & 62.3 & 50.4 & 6.0 & 13.3 & 10.4 & 0.7 & 2.7 & 28.1 \\
\hline $2000^{3} \ldots$ & 100.0 & 72.4 & 63.7 & 52.8 & 5.7 & 12.5 & 9.4 & 0.8 & 3.0 & 27.6 \\
\hline $1999^{4} \ldots \ldots$ & 100.0 & 72.1 & 62.8 & 51.5 & 5.9 & 13.2 & 10.2 & 0.6 & 3.0 & 27.9 \\
\hline $1999 \ldots \ldots \ldots \ldots \ldots \ldots$ & 100.0 & 71.0 & 62.0 & 51.0 & 5.5 & 13.0 & 10.0 & 0.6 & 3.0 & 29.0 \\
\hline $1998 \ldots \ldots$ & 100.0 & 70.1 & 61.1 & 50.5 & 5.8 & 12.9 & 9.8 & 0.6 & 3.1 & 29.9 \\
\hline $1997^{5} \ldots \ldots \ldots \ldots \ldots$ & 100.0 & 69.9 & 60.5 & 50.1 & 6.2 & 13.0 & 10.1 & 0.6 & 2.7 & 30.1 \\
\hline $1996 \ldots \ldots$ & 100.0 & 71.1 & 60.3 & 49.7 & 6.1 & 15.0 & 11.6 & 0.6 & 3.3 & 28.9 \\
\hline $1995 \ldots \ldots$ & 100.0 & 71.8 & 60.2 & 50.3 & 6.8 & 16.2 & 12.1 & 0.5 & 4.2 & 28.2 \\
\hline $1994^{6} \ldots$ & 100.0 & 73.3 & 61.7 & 51.3 & 7.4 & 16.9 & 12.6 & 0.4 & 4.7 & 26.7 \\
\hline $1993^{7} \ldots$ & 100.0 & 73.2 & 61.5 & 43.7 & (NA) & 16.0 & 11.7 & 0.6 & 4.4 & 26.8 \\
\hline $1992^{8} \ldots$ & 100.0 & 70.6 & 58.9 & 42.7 & (NA) & 14.9 & 11.2 & 0.7 & 3.7 & 29.4 \\
\hline $1991 \ldots$ & 100.0 & 73.1 & 62.1 & 47.0 & (NA) & 13.9 & 10.1 & 0.7 & 3.8 & 26.9 \\
\hline 1990. & 100.0 & 73.9 & 63.9 & 48.2 & (NA) & 13.1 & 8.9 & 0.6 & 4.4 & 26.1 \\
\hline $1989 \ldots$ & 100.0 & 74.9 & 65.7 & 51.1 & (NA) & 12.3 & 8.1 & 0.7 & 4.1 & 25.1 \\
\hline $1988 \ldots$ & 100.0 & 75.5 & 66.2 & 51.1 & (NA) & 12.0 & 7.9 & 0.7 & 3.9 & 24.5 \\
\hline $1987^{9} \ldots \ldots \ldots$ & 100.0 & 76.6 & 66.9 & 51.5 & $(\mathrm{NA})$ & 12.6 & 7.6 & 0.8 & 4.9 & 23.4 \\
\hline
\end{tabular}

See footnotes at end of table. 


\section{Table C-2.}

\section{Health Insurance Coverage by Age: 1987 to 2005-Con.}

(Numbers in thousands. People as of March of the following year)

\begin{tabular}{|c|c|c|c|c|c|c|c|c|c|c|}
\hline \multirow{3}{*}{ Age and year } & \multirow[b]{3}{*}{$\begin{array}{r}\text { Total } \\
\text { people }\end{array}$} & \multicolumn{8}{|c|}{ Covered by private and/or government health insurance } & \multirow[b]{3}{*}{$\begin{array}{r}\text { Not } \\
\text { covered }\end{array}$} \\
\hline & & \multicolumn{4}{|c|}{ Private health insurance } & \multicolumn{4}{|c|}{ Government health insurance } & \\
\hline & & Total & Total & $\begin{array}{r}\text { Employ- } \\
\text { ment } \\
\text { based }\end{array}$ & $\begin{array}{r}\text { Direct } \\
\text { purchase }\end{array}$ & Total & Medicaid & Medicare & $\begin{array}{c}\text { Military } \\
\text { health } \\
\text { care }^{1}\end{array}$ & \\
\hline \multicolumn{11}{|l|}{25 TO 34 YEARS } \\
\hline \multicolumn{11}{|l|}{ Numbers } \\
\hline 2005 & 39,480 & 29,069 & 25,489 & 23,683 & 2,234 & 4,753 & 3,451 & 541 & 1,058 & 10,412 \\
\hline $2004^{2}$ & 39,310 & 29,287 & 25,902 & 24,113 & 2,309 & 4,646 & 3,474 & 479 & 989 & 10,023 \\
\hline 2004 & 39,307 & 29,130 & 25,765 & 24,027 & 2,266 & 4,578 & 3,408 & 482 & 982 & 10,177 \\
\hline 2003 & 39,201 & 28,856 & 25,606 & 23,946 & 2,058 & 4,210 & 3,073 & 538 & 898 & 10,345 \\
\hline$\ldots \ldots \ldots$ & 39,243 & 29,474 & 26,492 & 24,800 & 2,098 & 3,944 & 2,801 & 455 & 922 & 9,769 \\
\hline 2001. & 38,670 & 29,619 & 26,905 & 25,306 & 2,072 & 3,653 & 2,587 & 489 & 817 & 9,051 \\
\hline $2000^{3}$ & 38,865 & 30,358 & 27,755 & 26,211 & 2,033 & 3,551 & 2,480 & 403 & 922 & 8,507 \\
\hline $1999^{4}$ & 39,031 & 30,309 & 27,730 & 26,153 & 2,114 & 3,578 & 2,458 & 332 & 974 & 8,723 \\
\hline 1999. & 37,786 & 29,031 & 26,567 & 25,150 & 1,939 & 3,429 & 2,344 & 323 & 940 & 8,755 \\
\hline 1998 & 38,474 & 29,347 & 26,726 & 25,096 & 2,049 & 3,616 & 2,476 & 423 & 991 & 9,127 \\
\hline $1997^{5}$ & 39,354 & 30,192 & 27,138 & 25,496 & 2,157 & 3,956 & 2,842 & 365 & 1,011 & 9,163 \\
\hline 1996. & 40,256 & 31,283 & 27,915 & 26,205 & 2,325 & 4,508 & 3,264 & 433 & 1,086 & 8,974 \\
\hline 1995. & 40,919 & 31,561 & 27,938 & 26,020 & 2,601 & 4,722 & 3,496 & 364 & 1,146 & 9,357 \\
\hline $1994^{6}$ & 41,388 & 32,274 & 28,386 & 26,417 & 2,874 & 5,261 & 3,748 & 359 & 1,435 & 9,115 \\
\hline $1993^{7}$ & 41,946 & 32,869 & $28,629^{\prime}$ & 25,432 & (NA) & 5,345 & 4,002 & 515 & 1,176 & 9,076 \\
\hline $1992^{8}$ & 42,356 & 33,389 & 28,994 & 26,164 & (NA) & 5,277 & 3,774 & 576 & 1,283 & 8,967 \\
\hline 1991. & 42,496 & 33,940 & 29,808 & 27,103 & (NA) & 5,031 & 3,542 & 495 & 1,327 & 8,555 \\
\hline 1990 & 42,905 & 34,581 & 30,875 & 27,920 & (NA) & 4,634 & 3,185 & 471 & 1,296 & 8,324 \\
\hline 1989 & 43,240 & 35,326 & 31,912 & 28,867 & (NA) & 4,217 & 2,692 & 363 & 1,396 & 7,914 \\
\hline 1988 & 43,239 & 35,319 & 31,996 & 29,140 & (NA) & 4,195 & 2,699 & 342 & 1,374 & 7,920 \\
\hline $1987^{9}$ & 42,953 & 35,645 & 32,296 & 29,198 & (NA) & 4,247 & 2,702 & 405 & 1,423 & 7,308 \\
\hline \multicolumn{11}{|l|}{ Percents } \\
\hline 2005 & 100.0 & 73.6 & 64.6 & 60.0 & 5.7 & 12.0 & 8.7 & 1.4 & 2.7 & 26.4 \\
\hline $2004^{2}$ & 100.0 & 74.5 & 65.9 & 61.3 & 5.9 & 11.8 & 8.8 & 1.2 & 2.5 & 25.5 \\
\hline 2004. & 100.0 & 74.1 & 65.5 & 61.1 & 5.8 & 11.6 & 8.7 & 1.2 & 2.5 & 25.9 \\
\hline 2003 & 100.0 & 73.6 & 65.3 & 61.1 & 5.2 & 10.7 & 7.8 & 1.4 & 2.3 & 26.4 \\
\hline 2002 & 100.0 & 75.1 & 67.5 & 63.2 & 5.3 & 10.1 & 7.1 & 1.2 & 2.3 & 24.9 \\
\hline 2001 & 100.0 & 76.6 & 69.6 & 65.4 & 5.4 & 9.4 & 6.7 & 1.3 & 2.1 & 23.4 \\
\hline $2000^{3}$ & 100.0 & 78.1 & 71.4 & 67.4 & 5.2 & 9.1 & 6.4 & 1.0 & 2.4 & 21.9 \\
\hline $1999^{4}$ & 100.0 & 77.7 & 71.0 & 67.0 & 5.4 & 9.2 & 6.3 & 0.8 & 2.5 & 22.3 \\
\hline 1999 & 100.0 & 76.8 & 70.3 & 66.6 & 5.1 & 9.1 & 6.2 & 0.9 & 2.5 & 23.2 \\
\hline 1998 & 100.0 & 76.3 & 69.5 & 65.2 & 5.3 & 9.4 & 6.4 & 1.1 & 2.6 & 23.7 \\
\hline $1997^{5}$ & 100.0 & 76.7 & 69.0 & 64.8 & 5.5 & 10.1 & 7.2 & 0.9 & 2.6 & 23.3 \\
\hline$\ldots \ldots \ldots \ldots$ & 100.0 & 77.7 & 69.3 & 65.1 & 5.8 & 11.2 & 8.1 & 1.1 & 2.7 & 22.3 \\
\hline 1995 & 100.0 & 77.1 & 68.3 & 63.6 & 6.4 & 11.5 & 8.5 & 0.9 & 2.8 & 22.9 \\
\hline $1994^{6}$ & 100.0 & 78.0 & 68.6 & 63.8 & 6.9 & 12.7 & 9.1 & 0.9 & 3.5 & 22.0 \\
\hline $1993^{7}$ & 100.0 & 78.4 & 68.3 & 60.6 & (NA) & 12.7 & 9.5 & 1.2 & 2.8 & 21.6 \\
\hline $1992^{8}$ & 100.0 & 78.8 & 68.5 & 61.8 & (NA) & 12.5 & 8.9 & 1.4 & 3.0 & 21.2 \\
\hline 1991. & 100.0 & 79.9 & 70.1 & 63.8 & (NA) & 11.8 & 8.3 & 1.2 & 3.1 & 20.1 \\
\hline 1990 & 100.0 & 80.6 & 72.0 & 65.1 & (NA) & 10.8 & 7.4 & 1.1 & 3.0 & 19.4 \\
\hline 1989 & 100.0 & 81.7 & 73.8 & 66.8 & (NA) & 9.8 & 6.2 & 0.8 & 3.2 & 18.3 \\
\hline 1988 & 100.0 & 81.7 & 74.0 & 67.4 & (NA) & 9.7 & 6.2 & 0.8 & 3.2 & 18.3 \\
\hline $1987^{\circ}$ & 100.0 & 83.0 & 75.2 & 68.0 & (NA) & 9.9 & 6.3 & 0.9 & 3.3 & 17.0 \\
\hline
\end{tabular}

See footnotes at end of table. 
Table C-2.

Health Insurance Coverage by Age: 1987 to 2005-Con.

(Numbers in thousands. People as of March of the following year)

\begin{tabular}{|c|c|c|c|c|c|c|c|c|c|c|}
\hline \multirow{3}{*}{ Age and year } & \multirow[b]{3}{*}{$\begin{array}{r}\text { Total } \\
\text { people }\end{array}$} & \multicolumn{8}{|c|}{ Covered by private and/or government health insurance } & \multirow[b]{3}{*}{$\begin{array}{r}\text { Not } \\
\text { covered }\end{array}$} \\
\hline & & & \multicolumn{3}{|c|}{ Private health insurance } & \multicolumn{4}{|c|}{ Government health insurance } & \\
\hline & & Total & Total & $\begin{array}{r}\text { Employ- } \\
\text { ment } \\
\text { based }\end{array}$ & $\begin{array}{r}\text { Direct } \\
\text { purchase }\end{array}$ & Total & Medicaid & Medicare & $\begin{array}{c}\text { Military } \\
\text { health } \\
\text { care }^{1}\end{array}$ & \\
\hline \multicolumn{11}{|l|}{35 TO 44 YEARS } \\
\hline \multicolumn{11}{|l|}{ Numbers } \\
\hline 2005 & 43,121 & 35,031 & 31,703 & 29,554 & 2,799 & 4,628 & 3,087 & 885 & 1,099 & 8,090 \\
\hline$\ldots \ldots \ldots \ldots \ldots \ldots$ & 43,351 & 35,257 & 31,871 & 29,777 & 2,799 & 4,721 & 3,194 & 902 & 1,122 & 8,093 \\
\hline $2004 \ldots \ldots \ldots \ldots \ldots \ldots \ldots$ & 43,350 & 35,240 & 31,883 & 29,824 & 2,773 & 4,680 & 3,135 & 900 & 1,129 & 8,110 \\
\hline $2003 \ldots \ldots \ldots \ldots \ldots \ldots$ & 43,573 & 35,688 & 32,533 & 30,386 & 2,793 & 4,420 & 2,860 & 940 & 1,111 & 7,885 \\
\hline $2002 \ldots \ldots \ldots \ldots \ldots \ldots \ldots$ & 44,074 & 36,292 & 33,240 & 31,180 & 2,817 & 4,240 & 2,728 & 881 & 1,121 & 7,781 \\
\hline $2001 \ldots \ldots \ldots \ldots \ldots \ldots \ldots$ & 44,284 & 37,153 & 34,315 & 32,386 & 2,649 & 4,003 & 2,532 & 860 & 1,066 & 7,131 \\
\hline $2000^{3} \ldots \ldots \ldots \ldots \ldots \ldots$ & 44,566 & 37,669 & 35,033 & 33,004 & 2,723 & 3,920 & 2,390 & 780 & 1,206 & 6,898 \\
\hline $1999^{4} \ldots \ldots \ldots \ldots \ldots \ldots$ & 44,474 & 37,748 & 34,908 & 32,620 & 3,151 & 4,028 & 2,390 & 825 & 1,257 & 6,726 \\
\hline $1999 \ldots \ldots \ldots \ldots \ldots \ldots \ldots$ & 44,805 & 37,428 & 34,624 & 32,423 & 3,057 & 3,988 & 2,340 & 856 & 1,256 & 7,377 \\
\hline $1998 \ldots \ldots \ldots \ldots \ldots \ldots \ldots$ & 44,744 & 37,036 & 34,134 & 32,019 & 2,937 & 4,190 & 2,579 & 749 & 1,232 & 7,708 \\
\hline $1997^{5} \ldots \ldots \ldots \ldots \ldots \ldots$ & 44,462 & 36,763 & 33,673 & 31,560 & 2,897 & 4,257 & 2,700 & 878 & 1,161 & 7,699 \\
\hline $1996 \ldots \ldots \ldots \ldots \ldots \ldots \ldots$ & 43,960 & 36,809 & 33,448 & 31,231 & 3,074 & 4,657 & 3,109 & 767 & 1,173 & 7,152 \\
\hline $1995 \ldots \ldots \ldots \ldots \ldots \ldots \ldots$ & 43,078 & 35,946 & 32,813 & 30,552 & 3,250 & 4,399 & 2,863 & 775 & 1,210 & 7,132 \\
\hline $1994^{6} \ldots \ldots \ldots \ldots \ldots \ldots$ & 42,334 & 35,555 & 32,271 & 29,894 & 3,714 & 4,628 & 2,918 & 711 & 1,415 & 6,780 \\
\hline $1993^{7} \ldots \ldots \ldots \ldots \ldots \ldots \ldots$ & 41,528 & 34,537 & 31,441 & 28,115 & (NA) & 4,189 & 2,619 & 647 & 1,276 & 6,991 \\
\hline $1992^{8} \ldots \ldots \ldots \ldots \ldots \ldots \ldots$ & 40,747 & 34,332 & 31,261 & 28,252 & (NA) & 3,990 & 2,310 & 718 & 1,324 & 6,415 \\
\hline $1991 \ldots \ldots \ldots \ldots \ldots \ldots \ldots$ & 39,578 & 33,902 & 31,118 & 28,339 & (NA) & 3,710 & 2,036 & 559 & 1,414 & 5,676 \\
\hline $1990 \ldots \ldots \ldots \ldots \ldots \ldots \ldots$ & 38,665 & 33,534 & 31,046 & 28,136 & (NA) & 3,542 & 1,894 & 578 & 1,368 & 5,131 \\
\hline $1989 \ldots \ldots \ldots \ldots \ldots \ldots \ldots$ & 37,195 & 32,541 & 30,329 & 27,641 & (NA) & 3,156 & 1,598 & 514 & 1,300 & 4,654 \\
\hline$\ldots \ldots \ldots \ldots$ & 35,873 & 31,294 & 29,168 & 26,651 & (NA) & 3,126 & 1,506 & 463 & 1,397 & 4,579 \\
\hline $1987^{9} \ldots \ldots \ldots \ldots \ldots \ldots$ & 34,692 & 30,557 & 28,353 & 25,868 & $(\mathrm{NA})$ & 3,186 & 1,590 & 447 & 1,373 & 4,135 \\
\hline \multicolumn{11}{|l|}{ Percents } \\
\hline $2005 \ldots \ldots \ldots \ldots \ldots \ldots \ldots$ & 100.0 & 81.2 & 73.5 & 68.5 & 6.5 & 10.7 & 7.2 & 2.1 & 2.5 & 18.8 \\
\hline $2004^{2} \ldots \ldots \ldots \ldots \ldots \ldots$ & 100.0 & 81.3 & 73.5 & 68.7 & 6.5 & 10.9 & 7.4 & 2.1 & 2.6 & 18.7 \\
\hline $2004 \ldots \ldots \ldots \ldots \ldots \ldots \ldots$ & 100.0 & 81.3 & 73.5 & 68.8 & 6.4 & 10.8 & 7.2 & 2.1 & 2.6 & 18.7 \\
\hline $2003 \ldots \ldots \ldots \ldots \ldots \ldots \ldots$ & 100.0 & 81.9 & 74.7 & 69.7 & 6.4 & 10.1 & 6.6 & 2.2 & 2.6 & 18.1 \\
\hline $2002 \ldots \ldots \ldots \ldots \ldots \ldots \ldots$ & 100.0 & 82.3 & 75.4 & 70.7 & 6.4 & 9.6 & 6.2 & 2.0 & 2.5 & 17.7 \\
\hline $2001 \ldots \ldots \ldots \ldots \ldots \ldots$ & 100.0 & 83.9 & 77.5 & 73.1 & 6.0 & 9.0 & 5.7 & 1.9 & 2.4 & 16.1 \\
\hline $2000^{3} \ldots$ & 100.0 & 84.5 & 78.6 & 74.1 & 6.1 & 8.8 & 5.4 & 1.8 & 2.7 & 15.5 \\
\hline $1999^{4} \ldots$ & 100.0 & 84.9 & 78.5 & 73.3 & 7.1 & 9.1 & 5.4 & 1.9 & 2.8 & 15.1 \\
\hline $1999 \ldots \ldots$ & 100.0 & 83.5 & 77.3 & 72.4 & 6.8 & 8.9 & 5.2 & 1.9 & 2.8 & 16.5 \\
\hline $1998 \ldots$ & 100.0 & 82.8 & 76.3 & 71.6 & 6.6 & 9.4 & 5.8 & 1.7 & 2.8 & 17.2 \\
\hline $1997^{5} \ldots$ & 100.0 & 82.7 & 75.7 & 71.0 & 6.5 & 9.6 & 6.1 & 2.0 & 2.6 & 17.3 \\
\hline $1996 \ldots$ & 100.0 & 83.7 & 76.1 & 71.0 & 7.0 & 10.6 & 7.1 & 1.7 & 2.7 & 16.3 \\
\hline $1995 \ldots$ & 100.0 & 83.4 & 76.2 & 70.9 & 7.5 & 10.2 & 6.6 & 1.8 & 2.8 & 16.6 \\
\hline $1994^{6} \ldots$ & 100.0 & 84.0 & 76.2 & 70.6 & 8.8 & 10.9 & 6.9 & 1.7 & 3.3 & 16.0 \\
\hline $1993^{7} \ldots$ & 100.0 & 83.2 & 75.7 & 67.7 & (NA) & 10.1 & 6.3 & 1.6 & 3.1 & 16.8 \\
\hline $1992^{8} \ldots$ & 100.0 & 84.3 & 76.7 & 69.3 & (NA) & 9.8 & 5.7 & 1.8 & 3.2 & 15.7 \\
\hline $1991 \ldots \ldots$ & 100.0 & 85.7 & 78.6 & 71.6 & (NA) & 9.4 & 5.1 & 1.4 & 3.6 & 14.3 \\
\hline $1990 \ldots$ & 100.0 & 86.7 & 80.3 & 72.8 & (NA) & 9.2 & 4.9 & 1.5 & 3.5 & 13.3 \\
\hline $1989 \ldots$ & 100.0 & 87.5 & 81.5 & 74.3 & (NA) & 8.5 & 4.3 & 1.4 & 3.5 & 12.5 \\
\hline $1988 \ldots$ & 100.0 & 87.2 & 81.3 & 74.3 & (NA) & 8.7 & 4.2 & 1.3 & 3.9 & 12.8 \\
\hline$\ldots \ldots \ldots \ldots \ldots$ & 100.0 & 88.1 & 81.7 & 74.6 & (NA) & 9.2 & 4.6 & 1.3 & 4.0 & 11.9 \\
\hline
\end{tabular}

See footnotes at end of table. 
Table C-2.

Health Insurance Coverage by Age: 1987 to 2005-Con.

(Numbers in thousands. People as of March of the following year)

\begin{tabular}{|c|c|c|c|c|c|c|c|c|c|c|}
\hline \multirow{3}{*}{ Age and year } & \multirow[b]{3}{*}{$\begin{array}{r}\text { Total } \\
\text { people }\end{array}$} & \multicolumn{8}{|c|}{ Covered by private and/or government health insurance } & \multirow[b]{3}{*}{$\begin{array}{r}\text { Not } \\
\text { covered }\end{array}$} \\
\hline & & & \multicolumn{3}{|c|}{ Private health insurance } & \multicolumn{4}{|c|}{ Government health insurance } & \\
\hline & & Total & Total & $\begin{array}{r}\text { Employ- } \\
\text { ment } \\
\text { based }\end{array}$ & $\begin{array}{r}\text { Direct } \\
\text { purchase }\end{array}$ & Total & Medicaid & Medicare & $\begin{array}{r}\text { Military } \\
\text { health } \\
\text { care }^{1}\end{array}$ & \\
\hline \multicolumn{11}{|l|}{45 TO 54 YEARS } \\
\hline \multicolumn{11}{|l|}{ Numbers } \\
\hline 2005 & 42,797 & 36,272 & 32,790 & 30,341 & 3,366 & 4,957 & 2,837 & 1,591 & 1,356 & 6,525 \\
\hline $2004^{2}$ & 41,961 & 35,712 & 32,380 & 30,016 & 3,249 & 4,893 & 2,656 & 1,552 & 1,421 & 6,249 \\
\hline$\ldots \ldots \ldots \ldots$ & 41,960 & 35,700 & 32,414 & 30,088 & 3,215 & 4,847 & 2,595 & 1,548 & 1,425 & 6,260 \\
\hline 2003 & 41,068 & 35,108 & 32,000 & 29,722 & 3,198 & 4,569 & 2,359 & 1,569 & 1,369 & 5,961 \\
\hline 2002 & 40,234 & 34,648 & 31,724 & 29,617 & 3,087 & 4,345 & 2,227 & 1,382 & 1,351 & 5,586 \\
\hline 2001 & 39,545 & 34,365 & 31,649 & 29,487 & 3,087 & 3,990 & 2,071 & 1,331 & 1,170 & 5,179 \\
\hline $2000^{3}$ & 38,720 & 33,955 & 31,373 & 29,329 & 3,042 & 3,964 & 1,996 & 1,384 & 1,169 & 4,764 \\
\hline $1999^{4}$ & 37,334 & 32,640 & 30,230 & 28,156 & 3,180 & 3,682 & 1,769 & 1,162 & 1,244 & 4,694 \\
\hline 1999 & 36,631 & 31,737 & 29,440 & 27,489 & 3,034 & 3,544 & 1,693 & 1,124 & 1,209 & 4,893 \\
\hline 1998 & 35,232 & 30,427 & 28,153 & 26,400 & 2,782 & 3,522 & 1,610 & 1,139 & 1,225 & 4,805 \\
\hline $1997^{5}$ & 34,057 & 29,319 & 27,063 & 25,099 & 2,967 & 3,677 & 1,766 & 1,133 & 1,281 & 4,738 \\
\hline 1996. & 33,013 & 28,504 & 26,266 & 24,329 & 2,889 & 3,705 & 1,875 & 948 & 1,282 & 4,509 \\
\hline 1995 & 31,584 & 27,398 & 25,269 & 23,332 & 3,227 & 3,495 & 1,756 & 856 & 1,267 & 4,186 \\
\hline $1994^{6}$ & 30,693 & 26,752 & 24,874 & 22,897 & 3,330 & 3,342 & 1,499 & 794 & 1,406 & 3,942 \\
\hline $1993^{7}$ & 29,522 & 25,424 & 23,332 & 20,654 & (NA) & 3,248 & 1,546 & 812 & 1,244 & 4,098 \\
\hline $1992^{8}$ & 28,332 & 24,311 & 22,354 & 19,862 & (NA) & 2,929 & 1,326 & 746 & 1,155 & 4,021 \\
\hline$\ldots \ldots \ldots$ & 27,025 & 23,695 & 21,973 & 19,751 & (NA) & 2,797 & 1,186 & 671 & 1,174 & 3,331 \\
\hline 1990 & 25,686 & 22,381 & 20,712 & 18,485 & (NA) & 2,645 & 1,124 & 644 & 1,161 & 3,306 \\
\hline$\ldots \ldots \ldots$ & 25,304 & 22,167 & 20,658 & 18,437 & (NA) & 2,497 & 1,017 & 582 & 1,123 & 3,137 \\
\hline 1988 & 24,622 & 21,686 & 20,171 & 18,131 & (NA) & 2,574 & 984 & 567 & 1,247 & 2,935 \\
\hline $1987^{9}$ & 23,861 & 21,167 & 19,765 & 17,574 & (NA) & 2,344 & 890 & 495 & 1,151 & 2,695 \\
\hline \multicolumn{11}{|l|}{ Percents } \\
\hline 2005 & 100.0 & 84.8 & 76.6 & 70.9 & 7.9 & 11.6 & 6.6 & 3.7 & 3.2 & 15.2 \\
\hline $2004^{2}$ & 100.0 & 85.1 & 77.2 & 71.5 & 7.7 & 11.7 & 6.3 & 3.7 & 3.4 & 14.9 \\
\hline 2004 & 100.0 & 85.1 & 77.2 & 71.7 & 7.7 & 11.6 & 6.2 & 3.7 & 3.4 & 14.9 \\
\hline 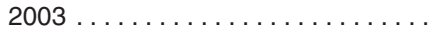 & 100.0 & 85.5 & 77.9 & 72.4 & 7.8 & 11.1 & 5.7 & 3.8 & 3.3 & 14.5 \\
\hline$\ldots \ldots \ldots, \cdots \cdots$, & 100.0 & 86.1 & 78.8 & 73.6 & 7.7 & 10.8 & 5.5 & 3.4 & 3.4 & 13.9 \\
\hline 2001 & 100.0 & 86.9 & 80.0 & 74.6 & 7.8 & 10.1 & 5.2 & 3.4 & 3.0 & 13.1 \\
\hline $2000^{3}$ & 100.0 & 87.7 & 81.0 & 75.7 & 7.9 & 10.2 & 5.2 & 3.6 & 3.0 & 12.3 \\
\hline $1999^{4}$ & 100.0 & 87.4 & 81.0 & 75.4 & 8.5 & 9.9 & 4.7 & 3.1 & 3.3 & 12.6 \\
\hline 1999 & 100.0 & 86.6 & 80.4 & 75.0 & 8.3 & 9.7 & 4.6 & 3.1 & 3.3 & 13.4 \\
\hline 1998 & 100.0 & 86.4 & 79.9 & 74.9 & 7.9 & 10.0 & 4.6 & 3.2 & 3.5 & 13.6 \\
\hline $1997^{5}$ & 100.0 & 86.1 & 79.5 & 73.7 & 8.7 & 10.8 & 5.2 & 3.3 & 3.8 & 13.9 \\
\hline 1996 & 100.0 & 86.3 & 79.6 & 73.7 & 8.8 & 11.2 & 5.7 & 2.9 & 3.9 & 13.7 \\
\hline 1995 & 100.0 & 86.7 & 80.0 & 73.9 & 10.2 & 11.1 & 5.6 & 2.7 & 4.0 & 13.3 \\
\hline $1994^{6}$ & 100.0 & 87.2 & 81.0 & 74.6 & 10.8 & 10.9 & 4.9 & 2.6 & 4.6 & 12.8 \\
\hline $1993^{7}$ & 100.0 & 86.1 & 79.0 & 70.0 & (NA) & 11.0 & 5.2 & 2.8 & 4.2 & 13.9 \\
\hline $1992^{8}$ & 100.0 & 85.8 & 78.9 & 70.1 & (NA) & 10.3 & 4.7 & 2.6 & 4.1 & 14.2 \\
\hline 1991. & 100.0 & 87.7 & 81.3 & 73.1 & (NA) & 10.3 & 4.4 & 2.5 & 4.3 & 12.3 \\
\hline 1990 & 100.0 & 87.1 & 80.6 & 72.0 & (NA) & 10.3 & 4.4 & 2.5 & 4.5 & 12.9 \\
\hline 1989 & 100.0 & 87.6 & 81.6 & 72.9 & (NA) & 9.9 & 4.0 & 2.3 & 4.4 & 12.4 \\
\hline$\ldots \ldots \ldots \ldots$ & 100.0 & 88.1 & 81.9 & 73.6 & (NA) & 10.5 & 4.0 & 2.3 & 5.1 & 11.9 \\
\hline $1987^{9}$ & 100.0 & 88.7 & 82.8 & 73.7 & (NA) & 9.8 & 3.7 & 2.1 & 4.8 & 11.3 \\
\hline
\end{tabular}

See footnotes at end of table. 
Table C-2.

Health Insurance Coverage by Age: 1987 to 2005-Con.

(Numbers in thousands. People as of March of the following year)

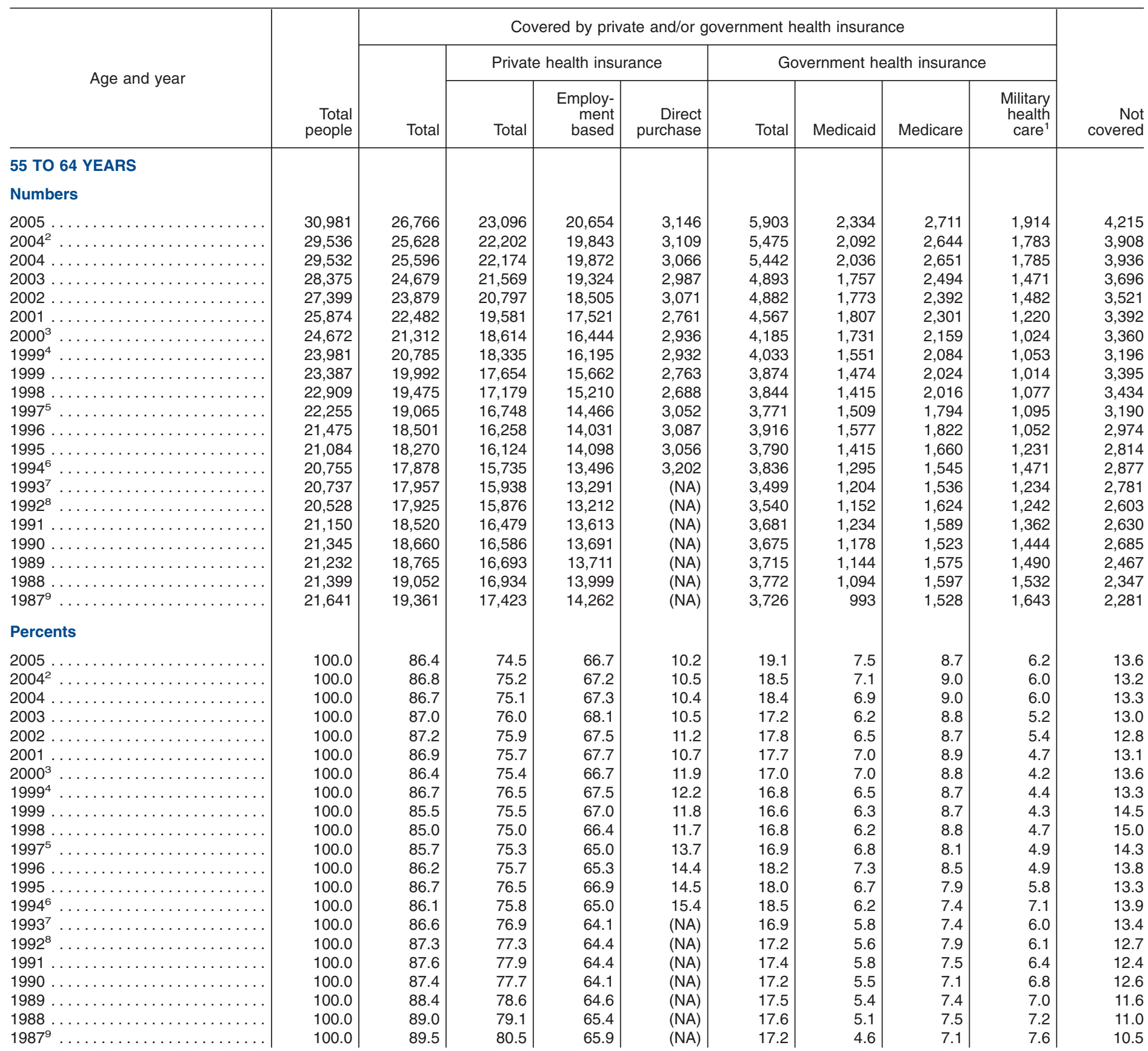

See footnotes at end of table. 
Table C-2.

Health Insurance Coverage by Age: 1987 to 2005-Con.

(Numbers in thousands. People as of March of the following year)

\begin{tabular}{|c|c|c|c|c|c|c|c|c|c|c|}
\hline \multirow{3}{*}{ Age and year } & \multirow[b]{3}{*}{$\begin{array}{r}\text { Total } \\
\text { people }\end{array}$} & \multicolumn{8}{|c|}{ Covered by private and/or government health insurance } & \multirow[b]{3}{*}{$\begin{array}{r}\text { Not } \\
\text { covered }\end{array}$} \\
\hline & & & \multicolumn{3}{|c|}{ Private health insurance } & \multicolumn{4}{|c|}{ Government health insurance } & \\
\hline & & Total & Total & $\begin{array}{r}\text { Employ- } \\
\text { ment } \\
\text { based }\end{array}$ & $\begin{array}{r}\text { Direct } \\
\text { purchase }\end{array}$ & Total & Medicaid & Medicare & $\begin{array}{c}\text { Military } \\
\text { health } \\
\text { care }^{1}\end{array}$ & \\
\hline \multicolumn{11}{|l|}{65 YEARS AND OVER } \\
\hline \multicolumn{11}{|l|}{ Numbers } \\
\hline 2005 & 35,505 & 35,046 & 21,078 & 12,666 & 9,650 & 33,862 & 3,397 & 33,727 & 2,611 & 459 \\
\hline $2004^{2}$ & 35,209 & 34,717 & 21,143 & 12,388 & 9,913 & 33,557 & 3,335 & 33,420 & 2,504 & 493 \\
\hline 2004. & 35,213 & 34,916 & 21,336 & 12,505 & 9,979 & 33,595 & 3,297 & 33,452 & 2,509 & 297 \\
\hline 2003. & 34,659 & 34,373 & 21,159 & 12,204 & 9,962 & 33,345 & 3,190 & 33,257 & 2,206 & 286 \\
\hline 2002. & 34,234 & 33,976 & 20,685 & 11,583 & 10,135 & 32,813 & 3,283 & 32,631 & 2,259 & 258 \\
\hline 2001. & 33,769 & 33,498 & 20,751 & 11,645 & 10,229 & 32,618 & 3,270 & 32,458 & 2,156 & 272 \\
\hline $2000^{3}$ & 33,566 & 33,314 & 20,702 & 11,278 & 10,671 & 32,398 & 3,339 & 32,289 & 1,410 & 251 \\
\hline $1999^{4}$ & 33,377 & 33,109 & 20,796 & 11,584 & 10,422 & 32,083 & 2,956 & 32,004 & 1,257 & 268 \\
\hline$\ldots \ldots \ldots$ & 32,621 & 32,199 & 20,054 & 11,169 & 10,049 & 31,312 & 2,917 & 31,231 & 1,232 & 422 \\
\hline 1998 . & 32,394 & 32,036 & 20,171 & 11,150 & 10,312 & 31,167 & 2,962 & 31,085 & 1,186 & 358 \\
\hline $1997^{5}$ & 32,082 & 31,749 & 20,687 & 10,963 & 10,853 & 30,942 & 2,901 & 30,870 & 1,125 & 333 \\
\hline 1996. & 31,877 & 31,541 & 21,224 & 10,948 & 11,567 & 30,714 & 3,215 & 30,616 & 998 & 336 \\
\hline 1995. & 31,658 & 31,358 & 21,754 & 11,137 & 12,148 & 30,597 & 2,820 & 30,521 & 1,152 & 300 \\
\hline $1994^{6}$ & 31,267 & 30,977 & 21,259 & 11,071 & 11,742 & 30,291 & 2,875 & 30,176 & 1,550 & 290 \\
\hline $1993^{7}$ & 30,779 & 30,416 & 20,324 & 9,947 & (NA) & 29,490 & 2,709 & 29,390 & 1,208 & 363 \\
\hline $1992^{8}$ & 30,430 & 30,082 & 20,643 & 9,944 & (NA) & 29,387 & 2,869 & 29,290 & 1,163 & 349 \\
\hline 1991. & 30,590 & 30,301 & 20,715 & 10,114 & (NA) & 29,465 & 2,891 & 29,377 & 1,178 & 289 \\
\hline 1990. & 30,093 & 29,816 & 20,566 & 10,002 & (NA) & 28,898 & 2,582 & 28,795 & 1,151 & 276 \\
\hline 1989. & 29,566 & 29,258 & 20,003 & 9,448 & (NA) & 28,337 & 2,576 & 28,251 & 1,105 & 308 \\
\hline 1988. & 29,022 & 28,747 & 19,841 & 9,171 & (NA) & 27,831 & 2,451 & 27,724 & 1,079 & 275 \\
\hline $1987^{9}$ & 28,487 & 28,181 & 20,127 & 8,830 & (NA) & 27,428 & 2,387 & 27,333 & 1,113 & 306 \\
\hline \multicolumn{11}{|l|}{ Percents } \\
\hline 2005 & 100.0 & 98.7 & 59.4 & 35.7 & 27.2 & 95.4 & 9.6 & 95.0 & 7.4 & 1.3 \\
\hline $2004^{2}$ & 100.0 & 98.6 & 60.0 & 35.2 & 28.2 & 95.3 & 9.5 & 94.9 & 7.1 & 1.4 \\
\hline$\ldots \ldots \ldots$ & 100.0 & 99.2 & 60.6 & 35.5 & 28.3 & 95.4 & 9.4 & 95.0 & 7.1 & 0.8 \\
\hline 2003 & 100.0 & 99.2 & 61.0 & 35.2 & 28.7 & 96.2 & 9.2 & 96.0 & 6.4 & 0.8 \\
\hline 2002. & 100.0 & 99.2 & 60.4 & 33.8 & 29.6 & 95.8 & 9.6 & 95.3 & 6.6 & 0.8 \\
\hline 2001 . & 100.0 & 99.2 & 61.5 & 34.5 & 30.3 & 96.6 & 9.7 & 96.1 & 6.4 & 0.8 \\
\hline $2000^{3}$ & 100.0 & 99.3 & 61.7 & 33.6 & 31.8 & 96.5 & 9.9 & 96.2 & 4.2 & 0.7 \\
\hline $1999^{4}$ & 100.0 & 99.2 & 62.3 & 34.7 & 31.2 & 96.1 & 8.9 & 95.9 & 3.8 & 0.8 \\
\hline$\ldots \ldots \ldots \ldots$ & 100.0 & 98.7 & 61.5 & 34.2 & 30.8 & 96.0 & 8.9 & 95.7 & 3.8 & 1.3 \\
\hline 1998 . & 100.0 & 98.9 & 62.3 & 34.4 & 31.8 & 96.2 & 9.1 & 96.0 & 3.7 & 1.1 \\
\hline $1997^{5}$ & 100.0 & 99.0 & 64.5 & 34.2 & 33.8 & 96.4 & 9.0 & 96.2 & 3.5 & 1.0 \\
\hline $1996 \ldots$ & 100.0 & 98.9 & 66.6 & 34.3 & 36.3 & 96.4 & 10.1 & 96.0 & 3.1 & 1.1 \\
\hline 1995. & 100.0 & 99.1 & 68.7 & 35.2 & 38.4 & 96.6 & 8.9 & 96.4 & 3.6 & 0.9 \\
\hline $1994^{6}$ & 100.0 & 99.1 & 68.0 & 35.4 & 37.6 & 96.9 & 9.2 & 96.5 & 5.0 & 0.9 \\
\hline $1993^{7}$ & 100.0 & 98.8 & 66.0 & 32.3 & (NA) & 95.8 & 8.8 & 95.5 & 3.9 & 1.2 \\
\hline $1992^{8}$ & 100.0 & 98.9 & 67.8 & 32.7 & (NA) & 96.6 & 9.4 & 96.3 & 3.8 & 1.1 \\
\hline $1991 \ldots$ & 100.0 & 99.1 & 67.7 & 33.1 & (NA) & 96.3 & 9.5 & 96.0 & 3.9 & 0.9 \\
\hline $1990 \ldots \ldots \ldots$ & 100.0 & 99.1 & 68.3 & 33.2 & (NA) & 96.0 & 8.6 & 95.7 & 3.8 & 0.9 \\
\hline 1989. & 100.0 & 99.0 & 67.7 & 32.0 & (NA) & 95.8 & 8.7 & 95.6 & 3.7 & 1.0 \\
\hline 1988 . & 100.0 & 99.1 & 68.4 & 31.6 & (NA) & 95.9 & 8.4 & 95.5 & 3.7 & 0.9 \\
\hline $1987^{9}$ & 100.0 & 98.9 & 70.7 & 31.0 & (NA) & 96.3 & 8.4 & 95.9 & 3.9 & 1.1 \\
\hline
\end{tabular}

(NA) Not available. Respondents were not asked detailed health insurance questions about direct-purchase coverage before the 1995 CPS ASEC.

${ }^{1}$ Military health care includes CHAMPUS (Comprehensive Health and Medical Plan for Uniformed Services)/Tricare and CHAMPVA (Civilian Health and Medical Program of the

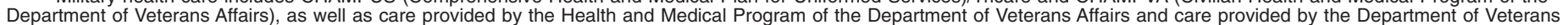

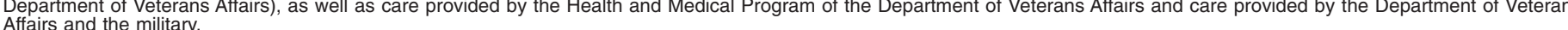
The military. dependents.

3 Implementation of a 28,000 household sample expansion.
4

4 Estimates reflect the results of follow-up verification questions and implementation of Census 2000-based population controls

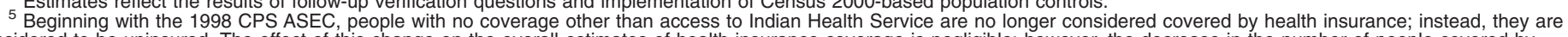

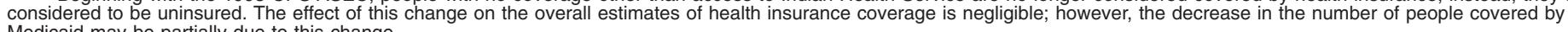
Medicaid may be partially due to this change.

${ }_{6}^{6}$ Health insurance questions were redesigned. Increases in estimates of employment-based and military health care coverage may be partially due to questionnaire changes.

Overall coverage estimates were not affected.

7 Data collection method changed from paper and pencil to computer-assisted interviewing

8 Implementation of 1990 census population controls.

${ }^{9}$ Implementation of a new CPS ASEC processing system.

Source: U.S. Census Bureau, Current Population Survey, 1988 to 2006 Annual Social and Economic Supplements. 
APPENDIX D.

COMPARISON OF STATE ESTIMATES

Figure D-1

Three-Year Average Percentage of People Without Health Insurance Coverage by State: 2003 to 2005

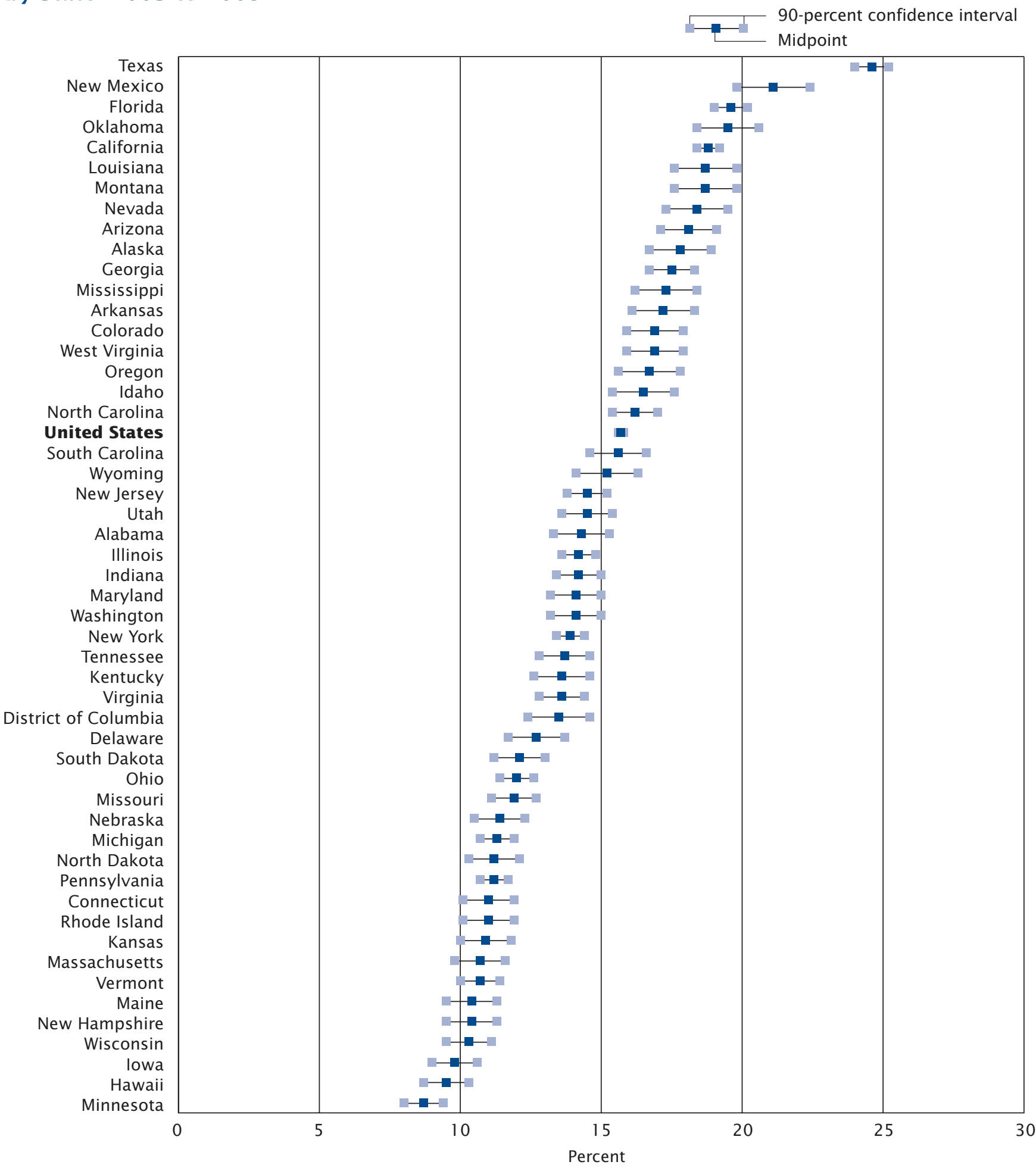

Source: U.S. Census Bureau, Current Population Survey, 2004 to 2006 Annual Social and Economic Supplements. 


